

\author{
Ricardo Gilson da Costa Silva \\ Amanda Michalski \\ Tiago Roberto Silva Santos \\ Organizadores
}

\title{
Geografias de Rondônia Território, Fronteira e Educação
}
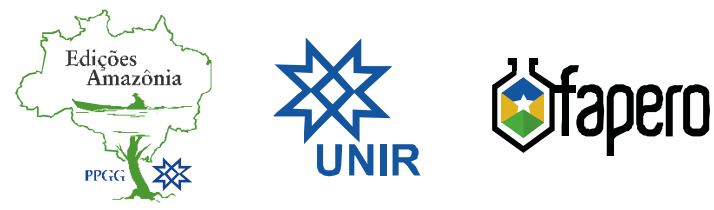


\section{UNIVERSIDADE FEDERAL DE RONDÔNIA - UNIR}

Reitora: Profa. Dra. Marcele Regina Nogueira Pereira

Vice-Reitor: Prof. Dr. José Juliano Cedaro

\section{NÚCLEO DE CIÊNCIAS EXATAS E DA TERRA - NCET}

Diretor: Prof. Dr. Ariel Adorno de Sousa

Vice-Diretor: Prof. Dr. Marinaldo Felipe da Silva

\section{PROGRAMA DE PÓS-GRADUAÇÃO MESTRADO E DOUTORADO EM GEOGRAFIA - PPGG}

Coordenador: Prof. Dr. Ricardo Gilson da Costa Silva

Vice-Coordenador: Prof. Dr. João Paulo Assis Gobo

\section{EDIÇÕES AMAZÔNIA PPGG - CONSELHO EDITORIAL}

Prof. Dr. Adnilson de Almeida Silva - UNIR, Porto Velho, Brasil

Prof. Dr. Dorisvalder Dias Nunes - UNIR, Porto Velho, Brasil

Profa. Msc. Francilene Sales da Conceição - UEA, Manaus, Brasil

Prof. Dr. Isaque dos Santos Sousa - UEA, Manaus, Brasil

Prof. Dr. Josué da Costa Silva - UNIR, Porto Velho, Brasil

Prof. Dr. João Paulo Assis Gobo - UNIR, Porto Velho, Brasil

Profa. Dra. Luciana Riça Mourão Borges - UNIR, Guajará-Mirim, Brasil

Profa. Dra. Maria Madalena de Aguiar Cavalcante - UNIR, Porto Velho, Brasil

Profa. Dra. Maria das Graças Silva Nascimento Silva - UNIR, Porto Velho, Brasil

Profa. Dra. Mariana Arzeno - UBA, Buenos Aires, Argentina

Prof. Dr. Márcio Douglas Amaral - UFPA, Belém, Brasil

Prof. Dr. Nilson Cesar Fraga, UEL, Londrina, Brasil

Prof. Dr. Ricardo Gilson da Costa Silva - UNIR, Porto Velho, Brasil

Profa. Dra. Rosa Ester Rossini - USP, São Paulo, Brasil

Prof. Dr. Silvio Simone da Silva - UFAC, Rio Branco, Brasil

Profa. Dra. Viviane Vidal da Silva - UFAM, Humaitá, Brasil

Prof. Dr. Hervé Théry - CNRS, Paris, França 
(C) by Ricardo Gilson da Costa Silva, Amanda Michalski

e Tiago Roberto Silva Santos

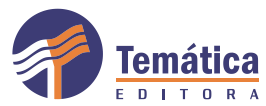

Rua Prudente de Morais, 2421 Centro

Porto Velho-RO

(69) 9.9246-7839

info@tematicaeditora.com.br

Comissão Técnica

Abel Sidney

Preparação de originais e revisão

Rogério Mota

Editoração eletrônica e capa

Fotos da capa: Alberto Júnior Ihv Kuhj Gavião (1),

Ricardo Gilson da Costa Silva (2)

Livro publicado com recurso da Fapero conforme Programa de apoio à Pesquisa

- PAP- chamada Fapero n. 04/2018, Processo n. 012427596201890.054/2018.

DOI: $10.5935 / 978-65-87350-35-6$

\section{Dados Internacionais de Catalogação na Publicação (CIP)}

G345 Geografias de Rondônia : território, fronteira e educação / Organizadores : Ricardo Gilson da Costa Silva, Amanda Michalski, Tiago Roberto Silva Santos. - Porto Velho : Temática Editora e PPGG/UNIR, 2021.

16.957 KB

ISBN 978-65-87350-35-6

1. Geografia humana. 2. Geografia crítica. I. Silva, Ricardo Gilson da Costa, org. II. Michalski, Amanda, org. III. Santos, Tiago Roberto Silva, org. IV. Programa de Pós-graduação Mestrado e Doutorado em Geografia PPGG da Universidade Federal de Rondônia - UNIR. V. Título.

CDD 918.11

CDU 911.3(811.1)

Ficha catalográfica elaborada pela Bibliotecária Zane S. S. Santos CRB 11/1081 


\section{Licença Creative Commons}

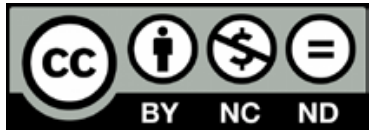

Esta obra é de acesso aberto. É permitida a reprodução parcial ou total desta obra, desde que citada a fonte e a autoria e respeitando a Licença Creative Commons indicada. É proibido qualquer uso para fins comerciais.

O conteúdo desta obra, conceitos e opiniões, inclusive sua revisão, é de responsabilidade de seus autores, os quais também se responsabilizam pelas imagens utilizadas.
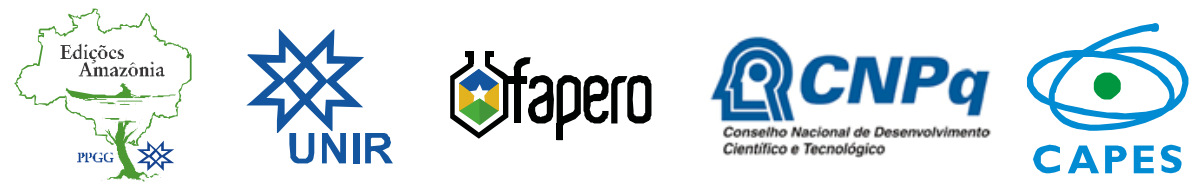


\section{Apresentação}

É com grande satisfação que organizamos esta coletânea referente às Geografias de Rondônia: território, fronteira e educação, envolvendo as temáticas: fronteira, territórios e educação. Trata-se de um livro que reúne alguns trabalhos desenvolvidos por pesquisadores e pesquisadoras do Laboratório em Gestão do Território - Laget da Universidade Federal de Rondônia - UNIR, que desde a sua institucionalização (2011) é coordenado pelo professor Ricardo Gilson da Costa Silva. O universo dos textos problematiza situações socioespaciais que nos permite, assim esperamos, compreender um pouco mais a complexidade de Rondônia.

No período de 10 anos, o Laget ajudou a desenvolver inúmeros trabalhos acadêmicos (iniciação científica, monografias, dissertações e teses), organizou seminários e oficinas temáticas, colaborou com dezenas de publicações em artigos científicos e livros, com autores de várias regiões do Brasil, mas especialmente da Amazônia. Desse modo, a coletânea é uma celebração aos dez anos de laboratório, reunindo alguns trabalhos desenvolvidos atinentes às dinâmicas territoriais de Rondônia.

O Laget está vinculado ao Departamento de Geografia e ao Programa de Pós-graduação em Geografia. Recepciona estudantes de graduação e pós-graduação, sendo um espaço institucional que busca auxiliar os estudantes em seus trabalhos acadêmicos, o que proporcionou a criação, em 2014, do Grupo de Pesquisa em Gestão do Território e Geografia Agrária da Amazônia - GTGA/ $\mathrm{CNPq}$, fortalecendo as ações de pesquisa no âmbito do laboratório.

O estado de Rondônia tem em sua geohistória um contexto de ciclos econômicos que incentivaram a migração e ocupação do 
território, porém, foi o projeto de colonização agrícola, a partir da década de 1970, promovido pela ditadura militar que se intensificou a migração e a transformação das dinâmicas sociais, culturais e territoriais, causando inúmeros conflitos para com os povos originários (indígenas) e comunidades tradicionais. A partir dessa política de ocupação populacional, aliada a instalação de infraestrutura como a pavimentação da rodovia BR-364, Rondônia passa a ser uma das frentes de expansão da fronteira na Amazônia, atraindo os interesses do capital, principalmente nas economias extrativas, produzindo diversas territorialidades contraditórias na forma de uso do espaço agrário.

Tendo este contexto histórico e essa configuração territorial como realidade, mas também com a possibilidade de certa dinamicidade em sua organização, os trabalhos que compõem essa coletânea abordam a dinâmica do processo de formação do território rondoniense, bem como suas características produtivas, inclusive refletindo na constituição de materiais didáticos para a educação escolar. Portanto, composta por 12 capítulos, com 15 autores, a coletânea está organizada em três eixos temáticos, sendo eles: Terra, Território e Fronteira; Espaço agrário: Agricultura Familiar e Agronegócio; e Geografia, Educação e Territorialidades.

O primeiro eixo temático, “Terra, Território e Fronteira”, apresenta trabalhos que problematizam os impactos resultantes do avanço da fronteira econômica na Amazônia, com ênfase no estado de Rondônia, sendo eles de ordem ambiental, social e econômica, produzindo novas territorialidades e conflitualidades.

Para iniciar este eixo, o trabalho "Terra, Poder e Território em Rondônia: processos históricos, interesses e perspectivas”, do professor Afonso Maria das Chagas (UNIR), problematiza os processos de colonização em contraposição à invisibilidade criada aos povos tradicionais em Rondônia; propõe, portanto, um processo de descolonização do olhar, do pensamento e da fala, como formas de compreender as lutas dos povos tradicionais e dos movimentos sociais em Rondônia, fazendo valer a sua condição histórico-cultural na defesa de seus territórios, frente aos avanços da fronteira e do capital. 
O segundo texto, intitulado "Fronteira, direitos humanos e territórios tradicionais em Rondônia (Amazônia Brasileira)", publicado em 2020 na Revista de Geografia Norte Grande (Chile), de autoria dos professores Ricardo Gilson da Costa Silva (UNIR), Amanda Michalski (Seduc/UNIR), discente Luciano Ítalo Tavares de Souza (Laget/UNIR) e Luís Augusto Pereira Lima (Seduc/AM), analisa os impactos da fronteira econômica em Áreas de Protegidas (Terras Indígenas e Reservas Extrativistas) em Rondônia. Conclui que a expansão da fronteira promovida pelos grupos econômicos (pecuária, madeira, grileiros, mineração e soja), com apoio do Estado, atingem a proteção ambiental e cultural dos povos amazônicos com fortes transgressões às leis de ordenamento territorial, cujo resultado institui um processo social vinculado à violência, ao crime ambiental e à negação dos direitos humanos e territoriais dos grupos sociais diretamente afetados.

Continuando as discussões, o texto "A caminho do Norte: cartografia dos impactos territoriais do agronegócio em Rondônia (Amazônia ocidental)", publicado em 2020 na Confins (USP e CNRS), de autoria dos professores Ricardo Gilson da Costa Silva e Amanda Michalski, analisa o percurso geográfico da soja, como principal produto do agronegócio brasileiro, e seus efeitos espaciais na Amazônia brasileira. Por meio da cartografia geográfica, problematiza-se os impactos territoriais do agronegócio em Rondônia, demonstrando que a inserção da soja produziu o deslocamento da fronteira agrícola em sub-regiões rondonienses que não tinham sido objeto de expansão agropecuária. Conclui que a fronteira se desloca em Áreas Protegidas, evidenciando, tanto a fragilidade governamental na gestão territorial, quanto os efeitos espaciais do agronegócio em converter florestas e áreas protegidas em espaço da agropecuária.

Encerra essa parte, o capítulo "Agroecologia política e movimentos sociais na Amazônia”, escrito pelo Gestor Ambiental e mestre em Geografia pelo PPGG/UNIR Lucas Ramos de Matos. Neste texto, o autor demonstra o processo de ecologização do Movimento dos Trabalhadores Rurais Sem Terra - MST, que resulta no processo de reapropriação social da natureza e reinvenção 
de territórios. Nesse sentido, evidencia-se a diferença na forma de relação com a terra e o território pelo MST em comparação ao agronegócio, sendo a prática camponesa mais sustentável e socialmente includente.

No segundo eixo deste livro, "Espaço agrário, Agricultura familiar e Agronegócio”, os textos abordam as características da organização espacial da produção agrícola, que justamente é responsável pelo avanço da fronteira, conflitualidades e estrutura fundiária.

As análises, neste eixo, iniciam com o texto "Especialização produtiva regional: uma abordagem sobre o agronegócio da soja no sul de Rondônia”, publicado em 2021 na revista Ciência Geográfica (AGB Bauru), do professor Juander Antônio de Oliveira Souza (UNIR/Cacoal). O trabalho aborda formação da Região Produtiva do Agronegócio (RPA) de Vilhena, a partir das dinâmicas territoriais e a espacialização da produção agrícola da soja. Para o autor, Vilhena a se transformou em uma cidade do agronegócio, adaptada para o atendimento das demandas agrícolas com a reestruturação da cidade e do campo, com concentração de terras e o êxodo rural.

Dando continuidade à análise da expansão de soja em Rondônia, o professor Carlos Alberto de Almeida Ricarte (Seduc) apresenta contribui com o texto "Territorialização, expansão e contradições do agronegócio no espaço agrário de Rondônia”, problematizando as transformações na estrutura socioespacial do estado, a partir do avanço territorial da produção de soja, com o objetivo de analisar as adversidades resultantes da expansão do agronegócio, como o desmatamento, conflitos por terras, grilagens e queimadas.

Em sequência, o texto "Cafeicultura em Rondônia: circuito espacial de produção, modernização e subordinação”, publicado em 2017 na revista Geografia (Londrina), dos professores Tiago Roberto Silva Santos (IFRO/Cacoal) e Ricardo Gilson da Costa Silva. A partir dos conceitos de circuito espacial da produção e círculo de cooperação, analisa-se a organização espacial da cafei- 
cultura, contextualizando o processo de modernização tecnológica na escala estadual. Conclui-se que a transformação agrícola indica o processo geral de subordinação da agricultura familiar ao capital, criando uma psicosfera do café, com formação de regiões produtivas, indicando que as variáveis do mercado nacional e global atingiram as áreas de fronteira agrícola.

Conclui o eixo temático o trabalho "A estrutura fundiária e suas especificidades no rural: apontamento para o planejamento territorial de Rondônia", do geógrafo Denes Luís Reis Pedrosa (Incra/Seagri). Analisa-se a importância da regulamentação fundiária para a criação de políticas de planejamento e gestão do território, por meio de georreferenciamento, sendo este processo como fundamental para o ordenamento territorial agrário de Rondônia.

O terceiro eixo definido para esta coletânea intitula-se "Geografia, Educação e Territorialidades". Os textos selecionados possibilitam compreender a importância do processo de ensino e educação aliado às territorialidades dos povos tradicionais, ligado às influências das questões agrárias na identificação das particularidades em Rondônia.

Para dar início às discussões desta terceira parte, apresentamos o capítulo "Geografia, livro didático e educação: problematizações da temática agrária no Ensino Fundamental", publicado em 2021 na Revista Cerrados (Unimontes), de autoria dos docentes Ricardo Gilson da Costa Silva, Mirian Pereira Suave (Seduc/RO) e Josélia Gomes Neves (UNIR/Ji-Paraná). A finalidade deste trabalho consistiu em analisar a temática agrária no livro didático a partir das perspectivas estudantis detalhadas em questões relacionadas e comparadas com os livros didáticos adotados em Rondônia. Conclui-se que as percepções de aprendizagem dos estudantes do $6^{\circ}$ ano do Ensino Fundamental acerca das questões agrárias postulam uma visão ancorada nas expectativas das políticas neoliberais, sem questionar seus efeitos na região amazônica e nos problemas sociais e ambientais que causam nas comunidades rurais. 
O texto a seguir, também propõe uma análise crítica do livro didático, escrito pelos docentes Josélia Gomes Neves, Ricardo Gilson da Costa Silva e Rosângela Castilho Valenciano (Semed/ Ji-Paraná), intitulado "O livro didático de Geografia e o estudo das terras indígenas diante da lei n. 11.645/2008: possibilidades de aprendizagens interculturais", publicado em 2021 na revista Acervo (Arquivo Nacional). A problematização envolve questões sobre a forma como se discute a questão indígena nos livros didáticos de geografia em turmas do $4^{\circ}$ e $5^{\circ}$ anos do ensino fundamental, principalmente em torno das tensões enfrentadas por esses grupos pelos agentes do agronegócio, que questionam a legitimidade da demarcação de seus territórios.

O capítulo "Território, contexto, histórico e educação escolar indígena Paiter Suruí - da liberdade à oficialidade", escrito pelos docentes Márcia Helena Gomes (Seduc/RO), Ricardo Gilson da Costa Silva e Josélia Gomes Neves, busca entender o contexto histórico dos diversos processos de territorialização dos Paiter Suruí e, a partir daí, entender as contribuições da educação escolar na configuração das particularidades da comunidade indígena. Esse processo passa pela participação de professores indígenas na educação escolar e valorização cultural.

Finaliza esse eixo temático o texto "Resistência e memória coletiva no Assentamento Madre Cristina em Ariquemes Rondônia”, da Assistente Social e mestranda em Geografia Jéssica Ferreira Costa. Busca compreender a memória coletiva e a identidade impressa na trajetória de ocupação camponesa no assentamento Madre Cristina, localizado no município de Ariquemes (Rondônia), e como essa estratégia de resistência fortalece os sujeitos para continuarem permanecendo no território.

Pela gentileza e apoio a esse trabalho, agradecemos aos editores dos periódicos Confins - Revista Franco-Brasileira de Geografia; Ciência Geográfica - Revista da Associação dos Geógrafos Brasileiros (AGB/Bauru); Cerrados - Revista do Programa de PósGraduação em Geografia da Universidade Estadual de Montes Claros - Unimontes; Geografia, Departamento de Geografia da Universidade Estadual de Londrina (UEL); Acervo, do Arquivo 
Nacional no Rio de Janeiro; e Revista de Geografia Norte Grande, da Ponti icia Universidad Católica de Chile.

Agradecemos o Programa de Pós-graduação Mestrado e Doutorado em Geogra ia - PPGG da Universidade Federal de Rondônia - UNIR, pela oportunidade de publicar esta coletâ-nea na Edições Amazônia PPGG/UNIR. Especialmente à Fapero, pelo apoio inanceiro ao Projeto de Pesquisa "Território e Territorialidades em Rondônia: estudo das dinâmicas agrárias e territoriais no norte/noroeste rondoniense", edital do Programa de apoio à pesquisa - PAP Chamada Fapero n. 04/2018, coorde-nado pelo professor Ricardo Gilson da Costa Silva.

Esperamos que esta coletânea seja efetivamente um trabalho que expresse, ainda que parcialmente, os 10 anos do Laboratório de Gestão do Território, com re lexões acerca das inúmeras territorialidades que se con iguram em Rondônia a partir de dinâmicas agrárias, contribuindo para o reconhecimento da importância de se valorizar as comunidades tradicionais, os povos originários, camponeses, natureza e educação pública.

Porto Velho e Cacoal, novembro de 2021.

Ricardo Gilson da Costa Silva, Tiago Roberto Silva Santos e Amanda Michalski

Organizadores 


\section{SUMÁRIO}

Apresentação 5

\section{PARTE I - TERRA, TERRITÓRIO E FRONTEIRA}

1 Terra, poder e território em Rondônia: processos históricos, interesses e perspectivas 15

Afonso Maria das Chagas

2 Fronteira, direitos humanos e territórios tradicionais em Rondônia (Amazônia brasileira) 47

Ricardo Gilson da Costa Silva

Amanda Michalski

Luciano Ítalo Tavares de Souza

Luís Augusto Pereira Lima

3 A caminho do Norte: cartografia dos impactos territoriais do agronegócio em Rondônia (Amazônia ocidental) 71

Ricardo Gilson da Costa Silva

Amanda Michalski

4 Agroecologia política e movimentos sociais na Amazônia 103

Lucas Ramos de Matos

\section{PARTE 2 - ESPAÇO AGRÁRIO, AGRICULTURA FAMILIAR E AGRONEGÓCIO}

5 Especialização produtiva regional: uma abordagem sobre o agronegócio da soja no sul de Rondônia 123

Juander Antonio de Oliveira Souza

G Territorialização, expansão e contradições do agronegócio no espaço agrário de Rondônia 157

Carlos Alberto de Almeida Ricarte 
7 Cafeicultura em Rondônia: circuito espacial de produção, modernização e subordinação 179

Tiago Roberto Silva Santos

Ricardo Gilson da Costa Silva

8 A estrutura fundiária e suas especificidades no rural: apontamento para o planejamento territorial de Rondônia 201

Denes Luís Reis Pedrosa

\section{PARTE 3 - GEOGRAFIA, EDUCAÇÃO E TERRITORIALIDADES}

9 Geografia, livro didático e educação: problematizações da temática agrária no ensino fundamental 221

Ricardo Gilson Costa Silva

Mirian Pereira Suave

Josélia Gomes Neves

10 O livro didático de geografia e o estudo das terras indígenas diante da Lei n. 11.645/2008: possibilidades de aprendizagens interculturais? 249 Josélia Gomes Neves

Ricardo Gilson da Costa Silva

Rosângela Castilho Valenciano

11 Território, contexto histórico e educação escolar indígena Paiter Suruí: da liberdade à oficialidade 269

Márcia Helena Gomes

Ricardo Gilson da Costa Silva

Josélia Gomes Neves

12 Resistência e memória coletiva no Assentamento Madre Cristina em Ariquemes - Rondônia 289

Jéssica Ferreira Costa

Súmula Curricular 306 


\section{PARTE 1}

TERRA, TERRITÓRIO E FRONTEIRA 


\title{
TERRA, PODER E TERRITÓRIO EM RONDÔNIA: PROCESSOS HISTÓRICOS, INTERESSES E PERSPECTIVAS
}

\author{
Afonso Maria das Chagas"
}

\section{INTRODUÇão: A AMAZÔNIA COMO CAMPO DE DISPUTAS TERRITORIAIS E PROPRIETÁRIAS}

Até a chegada dos europeus na América Latina, no século XV, sem dúvida, a maior riqueza dos povos que aqui viviam era a terra com todo seu conteúdo simbólico de pertencimento, espaço vital, relação e identidade. Os habitantes originários se reconheciam nesta relação como "Povos das florestas, das águas, dos rios, das montanhas". A terra e o território como espaço relacional é reconhecida como Pachamama (Mãe Terra) para os Quéchuas, Tekoha (Guarani-Kaiowá), como "lugar onde realizamos nosso modo de ser" (Mura, 2004).

Lugar de relações e coexistência com todos os outros seres vivos neste espaço onde as relações se processam, como exemplo. Inclusive nestas construções e narrativas há a projeção do lugar do ideal de convivência, das possibilidades, que sempre orientam os horizontes comunitários onde o espaço da convivência é a Yby marã e'yma (Terra Sem Males), para os Guaranis. Tais conceitos são cosmovisões de alcance existencial mais que documental, pois traduzem mais que lugar de trânsito ou de apropriação, são espaços de pertencimento.

Quanto à ideia de propriedade, há um conflito conceitual. Para a modernidade ocidental, a "propriedade da terra" é um dos basilares direitos do indivíduo proprietário. Este "sagrado direito", é e deve ser protegido pelo Estado e por ele legitimado. Para os povos indígenas e povos tradicionais, em regra, o indivíduo não possui ou se apropria da terra, uma vez que são os indivíduos, as coletividades que pertencem à

\footnotetext{
" https://orcid.org/0000-0002-5484-9937
} 


\section{Geografias de Rondônia: Território, Fronteira e Educação}

terra. A vida destes povos, sua conservação e sentido de pertença, estão em íntima sintonia com a vida e a conservação desta terra ou território.

Assim, a ideia de propriedade, de soberania, de cultura, de direitos, com todo o discurso jurídico instituinte e legitimante que lhe é própria, é desafiada. O sentido de "territorialidade", seu alcance e finalidade, conforme Paul Elliot Little, supõe a desconstrução dos esquemas e padrões monistas do Direito proprietário positivado (Little, 2002).

Tal abordagem, de início, levanta uma perspectiva identitária onde o fenômeno do "pertencimento" é traduzido numa relação vinculante e articulada entre a identidade étnica e a sua relação com seu território. Em outras palavras, tal fenômeno é compreendido como consciência histórico-cultural onde este território "o pertence e lhe pertence". Por isso que não há como abordar esta dimensão da territorialidade sem ter presente as contingências históricas, os processos sociais e políticos. Para Little, portanto:

A territorialidade é um esforço coletivo de um grupo social para ocupar, usar, controlar e se identificar com uma parcela específica de seu ambiente biofísico, convertendo-a assim em seu "território" ou homeland. [...] O fato de que um território surge diretamente das condutas de territorialidade de um grupo social implica que qualquer território é um produto histórico de processos sociais e políticos. (Little, 2002, p. 3).

Importante perceber que para Little (2002) o conceito de territorialidade, no caso brasileiro, envolve a questão da diversidade fundiária que se faz também compreender por meio da diversidade sociocultural do Brasil. Desafia, portanto, não só a superação de uma visão que pensa o território apenas como elemento de constituição do Estado, como demarcação de fronteiras, mas também a superação do conceito de território, pensado apenas como referência fundiária, ordenamento de terras. Sem esta ruptura cognitiva não há reconhecimento de direitos.

A territorialidade é assim, ferramenta de consciência social onde confluem os processos sociais e históricos desta identidade. É mais que espaço, uma vez que indica a funcionalidade deste espaço nas formas de representação, na construção simbólica do vivido histórico, e, portanto, incide em instrumento de consciência, reivindicação de direitos e afirmação de identidades. Secularmente, no entanto, a percepção deste fenô- 
Terra, poder e território em Rondônia: processos históricos, interesses e perspectivas

meno, assim como os direitos que a sustentam, foi mantida à margem, como se fossem tais povos, escondidos (Souza Filho, 1998).

$\mathrm{Na}$ literatura latino-americana há, na obra do escritor e jornalista peruano Manuel Scorza, um texto que simboliza bem esta ideia. Em seu livro História de Garabombo, o invisivel, o personagem, representa um herói coletivo que, no caso, simboliza a luta contra o latifúndio, pelo reconhecimento dos direitos e pela dignidade de seu povo. Garabombo, a princípio julgava ter uma doença, depois imaginou possuir o dom da invisibilidade. Com o passar do tempo ele vai percebendo como adquiriu este dom e o que fazer para transformar isso em benefício e arma de resistência. É possível perceber tal fenômeno nos fragmentos abaixo:

- Não me viram.

- Mas eu vejo você!

- É que você tem nosso sangue, mas os brancos não me vêem. Passei sete dias sentado na porta da repartição. As autoridades iam e viam, mas não olhavam para mim.

$\mathrm{Na}$ prisão compreendera a verdadeira natureza de sua doença. Não o viam porque não queriam vê-lo. Era invisível como eram invisíveis todas as reclamações, os abusos e as queixas (Scorza, 1975, p. 143).

Mais que ironia em Scorza, há uma constatação: a invisibilidade foi a marca estratégica dos processos de colonialidade. Na narrativa mítica e satírica, Garabombo entende a forma como o Estado em suas várias repartições ignorava as reivindicações das comunidades indígenas. Inclusive, quando portava os documentos oficiais de que o título das terras havia sido destinado a estas comunidades, ainda assim, permaneciam invisíveis aos olhos do Estado. Além do mais, o simbolismo da invisibilidade de Garabombo se manifestava ante os poderes oficiais, principalmente pelo fato de que, ele, Garabombo, havia percebido que as pressões e reivindicações de grupos isolados, frequentemente eram reprimidas à força. Assim, ele consegue dar um sentido coletivo a estas reivindicações, mudando a estratégia. Logo, a estratégia estatal igualmente muda, ao criar mecanismos institucionais de ignorar tais demandas, "invisibilizando" tais reivindicações quando as mesmas eram requeridas no campo institucional. 
O desvelamento desta cortina de invisibilidade tem sido uma atitude de profundos impactos no cenário latino-americano. Registre-se, como veremos, sobretudo a partir dos meados da década de 1980, uma ressignificação das organizações dos povos indígenas, quilombolas, seringueiros, ribeirinhos, entre tantos. A atuação articulada destas pautas reivindicatórias não só trouxe à luz a força destes sujeitos coletivos, como também demarcaram um novo espaço de atuação, para além dos velhos esquemas de clientelismo e cooptação. Os processos e movimentos articulados em torno dos textos constitucionais em diversos países da América Latina atestam este fenômeno (Wolkmer, 2003; Fajardo, 2012, Baldi, 2013).

Naquilo que compõe ou constitui a dimensão socioespacial em Rondônia tal perspectiva de análise é imprescindível. A dinâmica da invisibilidade ante a lógica do reconhecimento oficial é condição inexorável para a manutenção do controle instituído. A possibilidade de reverter esta perspectiva, na forma em que os sujeitos coletivos se reconhecem e ingressam na arena de disputa do reconhecimento do "outro", é igualmente incomplacente. Assim, busca-se, aqui, elencar alguns elementos de análise que potencializarão ou não, esta disputa por reconhecimento e direitos.

\section{QUESTÕES TERRITORIAIS EM RONDÔNIA: ENCOBRIMENTOS, CONFLITOS E PROTAGONISMOS}

Falar em questões territoriais no contexto histórico político e econômico do Estado de Rondônia é, antes de tudo, reconhecer-se navegante em águas revoltas, desconhecidas, e mais que isso, ignoradas ou encobertas. A narrativa histórica oficial em muito é retórica. A eloquência desta narrativa, enfim, que vai da historiografia à biografia de heróis, colonizadores, bandeirantes e pioneiros, mais encobre que revela. O simbolismo desta dinâmica, no entanto, é cristalino. Para dominar e explorar é preciso criar invólucros, embalagens conceituais, narrativas de heróis e, sobretudo, esconder as vítimas.

Faz-se necessário, portanto, do ponto de vista da nossa formação sociopolítica, admitir que Rondônia é muito mais que território de "destemidos pioneiros" e "sentinelas avançadas". Desta forma, a perspectiva do olhar se institui como um caleidoscópio de possibilidades, onde consensos artificiais em torno de uniformizações superficiais devem ser relegados. A diversidade é pressuposta, pois só assim haverá possibilidade 
Terra, poder e território em Rondônia: processos históricos, interesses e perspectivas

concreta de emergência da polifonia contra a homofonia, da pluralidade dos sujeitos históricos e, por que não, da possibilidade de compreender o particular no geral, nas interações e nas diferentes composições em que os contatos e os contextos se expressam, de forma dinâmica e plural.

A dimensão do espaço, como já comentado, marca um primeiro elemento desta realidade complexa. Enquanto o colonizador, seja ele, Estado ou empresas privadas, enxergava e nomeava este espaço como "terra nullius", ou "vazio demográfico", legitimava-se as condições pressupostas da colonização. No entanto, não há como ignorar: aqui estavam os povos indígenas e as comunidades tradicionais amazônicas, que se reconheciam e se reconhecem como seringueiros, ribeirinhos, quilombolas ou "Povos da Floresta".

Tendo em consideração a questão indígena, conforme o Conselho Indigenista Missionário - CIMI (2015), o Estado de Rondônia possui 61 povos indígenas, entre estes, 6 povos isolados. Falam 16 línguas diferentes e estão distribuídos por mais de 30 municípios. Em 2015, das áreas indígenas, 22 ainda não havia sido tomada nenhuma providência em relação à questão fundiária.

Quanto à questão quilombola, conforme dados divulgados pelo próprio Incra ${ }^{1}$, até o momento foram identificadas 9 comunidades de remanescentes quilombolas em 6 municípios, ao longo do Vale do Rio Guaporé. Destas, até o momento, apenas uma havia sido titulada, até julho de 2017. A população correspondente é próxima a 300 famílias.

Quanto às Reservas Extrativistas (Resex), no Estado de Rondônia são em número de 21 Unidades estaduais e 3 federais, localizadas em 8 municípios. Também somam em torno de 300 famílias de extrativistas ao todo 2 . Importante ressaltar que, na Amazônia, de modo geral, a criação das Resex contou sobretudo com a mobilização das comunidades de habitantes das florestas que habitavam a região há muito tempo

\footnotetext{
${ }^{1}$ Informações constantes de Relatório de Comunidades Quilombolas em Rondônia, distribuído pelo Incra, sob a responsabilidade de William dos Santos Ramos Coimbra, Coordenador do Serviço de Regularização dos Territórios Quilombolas do Incra SR-17/ RO, em 28.09.2016.

${ }^{2}$ As informações são baseadas em artigo de Gleimiria Batista da Costa e Heleniza Ávila Campos (Práticas tradicionais em Reservas Extrativistas no Estado de Rondônia), comunicação oral no VI Seminário Internacional Sobre Desenvolvimento Regional, em Santa Cruz do Sul/RS, de 4 a 6 de setembro de 2013. Buscou-se também informações junto à Organização dos Seringueiros de Rondônia.
} 
(Allegretti, 2002). Há que se ressaltar, contudo, que somos constituídos por uma complexidade, que demanda antes de tudo, esforço por compreensão. Há quem fale, pois, em "agroextrativismo" em vez de "extrativismo", denotando assim, que o próprio conceito, que na origem buscou inspiração na forma de uso e pertencimento das comunidades indígenas, se alterou. É o que se vê, inclusive nas formas estatais de ocupação propostas, ao se falar em sistemas agroflorestais, Projetos de Desenvolvimento Sustentável, etc. (Costa, 2012).

Em relação aos povos ribeirinhos, há consenso, inclusive entre os pesquisadores ${ }^{3}$, da dificuldade de estimar o quantitativo populacional desta categoria. Seja no Vale do Madeira ou no Vale do Guaporé, as comunidades ribeirinhas e em especial a cultura do ribeirinho é influenciada pelo rio que é o seu referencial principal, seu território, seu ambiente e sua vida. Conhecem e se relacionam com o "urbano", porém, este não o atrai ${ }^{4}$.

Vale aqui observar que, os chamados povos tradicionais (comunidades indígenas, quilombolas, ribeirinhos, extrativistas e seringueiros), sofreram, em regra, a lógica e a dinâmica da desterritorialização, e em alguns casos, a reterritorialização. Como já anotado, as formas particulares de perceber e de se relacionar com a natureza, para estes povos, traduz, enquanto tal, uma perspectiva existencial e "convivencial", sempre em perspectiva coletiva. Esta "existência social", sua constituição, enquanto condição vital, se confrontou violentamente no processo de colonização em Rondônia. Neste campo, conflituoso, muitos discursos, institucionais e formalizados, foram organizados com a finalidade espe-

\footnotetext{
${ }^{3}$ A este respeito: CHAVES, Maria P. S. R. Uma experiência de pesquisa-ação para gestão comunitária de tecnologias apropriadas na Amazônia: o estudo de caso do assentamento de Reforma Agrária Iporá. 2001. Tese (Doutorado em Política Científica e Tecnológica) - Universidade Estadual de Campinas, Campinas; BENATTI, José Heder. Posse agroecológica e manejo florestal. Curitiba: Juruá, 2003; BARRETO FILHO, Henyo T. Populações tradicionais: introdução à crítica da ecologia política de uma noção. In: Sociedades Caboclas Amazônicas: modernidade e invisibilidade. São Paulo: Annablume, 2006.

${ }^{4}$ A este respeito, interessante estudo de Eric Dardel (Dardel, 2011), onde constata o autor que para além da historicidade, onde uma situação temporal concede a presença ao existir, há a "geograficidade", que circunstancia esta existência através de uma presença na terra, ou em outras palavras, a geografia é originalmente a própria existência, ou como filosoficamente pressupunha Heidegger, uma forma de "ser-no-mundo" (dasein). Em Dardel, portanto, o espaço geográfico é o mundo da existência cotidiana, que agrupa dimensões do conhecimento e, também, da ação e da afetividade.
} 
cífica e uniformizante de legitimar interesses privados e corporativizados, voltados para a dominação, controle e manipulação do espaço territorial. Neste sentido, interpreta Silva:

A intervenção do Governo Federal (agente territorial público) produziu uma nova geografia da Amazônia caracterizada pelos processos econômicos, sociais e territoriais inerentes ao avanço do capital. Estes assumem proeminência no cotidiano local e regional, gestando um alargamento do contexto social quando os feixes de forças do capital e de expansão da fronteira agrícola se territorializam e modificam, sobremaneira, a sociabilidade regional (Silva, 2010, p. 87).

E esta intervenção estatal se deu no bojo dos processos de colonização implementados em Rondônia, sobretudo a partir da década de 1970. Para tal, repagina-se as velhas narrativas de "vazios demográficos" e "paraíso perdido" (Cunha, 1994), do início do século XX, e, passando pela decantada "marcha para o oeste", da década de 1940, agrega-se às novas narrativas do "integrar para não entregar" e da "terra sem homens para homens sem-terra". Reaviva-se o espírito dos "bandeirantes" e das "sentinelas avançadas", recriando o novo sentimento de integração nacional.

Para grandes objetivos, grandes aportes e estruturas. Inicialmente uma legislação e aparato regulamentatório específico e, assim, o Estatuto da Terra, ao lado das Concessões administrativas, "obstruiriam" a política de Reforma Agrária, substituindo-a por um Projeto de Colonização. Para tanto, cria-se o Incra, onde a colonização vem antes da Reforma Agrária, porque agora se tem um Plano de Integração Nacional (PIN). Iniciam-se as obras da Rodovia Transamazônica, para pouco mais tarde estruturar e implementar a Rodovia 364.

Neste último caso, em 1978, o governo brasileiro recorre-se a um estratégico parceiro. Solicitou apoio técnico e financeiro do Banco Mundial para a pavimentação da mencionada rodovia com a ideia inicial de ligar Cuiabá a Porto Velho, para posteriormente, chegar a Rio Branco, no Acre. O aporte econômico, em 1981, foi implementado sob o escopo retórico de "desenvolvimento regional", no valor de US\$ 1,6 bilhão, com a finalidade de atender o oeste do Estado do Mato Grosso e o Estado de Rondônia. O eixo principal desta estratégia era o asfalta- 


\section{Geografias de Rondônia: Território, Fronteira e Educação}

mento da estrada. A aprovação do projeto foi antecedida de muitas críticas, seja pela viabilidade da colonização em região, cujos solos não eram apropriados pela agricultura que praticava no centro-sul do país, seja pela existência de enormes prejuízos que pudessem (e seriam) causados às populações indígenas da região em decorrência do desordenado processo de ocupação das terras pelos colonos migrantes (Allegretti, 2002).

O processo da colonização dirigida, em Rondônia, planejada e legitimada pela política estatal oficial, responderia, assim, à algumas questões fundamentais, que ficaram pendentes. Em primeiro lugar, o desastre do projeto colonizatório da transamazônica, aberto às pressas sob o lema delirante da integração nacional, inviável e longe de atingir seu alegado objetivo de origem, ou seja, promover o desenvolvimento regional ao longo do eixo Leste-Oeste da Amazônia (Pedriali, 2016). Em segundo lugar, e talvez o mais importante para muitos autores (Ianni, 1979; Oliveira, 1998; Santos, 1993, Becker, 1990), o processo de colonização, naquilo que se materializou e simbolizou, sobretudo, como um sistemático processo de contrarreforma agrária. Assim, o conjunto estratégico do empreendimento voltava-se, antes de mais nada, para mitigar as emblemáticas tensões refletidas nas distorções fundiárias do sul e sudeste do Brasil: concentração de terras, violência no campo e "modernização" da agricultura sob a propaganda do desenvolvimento. Sob o mote da "modernização da agricultura", o foco principal voltava-se a manter intacta a desigual estrutura fundiária do país. Por outro lado, não se tratava de transformar o latifundiário em empresário, ou protagonista do capitalismo, mas, transformar os capitalistas, industriais e urbanos, do centro-sul do país, em proprietários de terras, latifundiários (Oliveira, 2001).

Há que se ter em conta, ainda, um terceiro elemento, igualmente de fundamental importância: os interesses transnacionais na Amazônia. O Estado brasileiro sempre foi o principal e indispensável interlocutor do capital internacional. Seja em perspectiva de geopolítica estratégica (Banco Mundial), seja nas iniciativas privadas, o capital internacional e suas diretrizes de mercado, ocuparam-se simbólica e literalmente do espaço amazônico. Presentes desde a concepção estratégica da ocupação territorial, a lógica internacional, de forma clara e desvelada, se concretizou, financeiramente, politicamente e espacialmente. Seja no plano dos interesses privados ou corporativizados no aspecto minerário, no Pará, seja no custeio da pavimentação da BR-364, seja na sustentação financeira dos planos regionais, como o Polonoroeste, os interesses interna- 
Terra, poder e território em Rondônia: processos históricos, interesses e perspectivas

cionais sempre se fizeram presentes. Esta presença inclusive se efetivou no pensamento, articulação e efetivação de uma mentalidade de desenvolvimento, "capturando" inclusive segmentos e organizações sociais e coletivas como no caso do Programa Piloto para a Proteção das Florestas tropicais do Brasil - PPG7. Impôs tendências e estratégias, direcionou aplicação de recursos e condicionou a perspectiva de desenvolvimento para a região, mesmo quando os equívocos se faziam evidentes (Caso da implementação do Programa Polonoroeste e de sua sucessiva correção, o Programa Planafloro).

\section{A VIOLÊNCIA COMO MÉTODO: ENTRE A RESISTÊNCIA E A CONTINUIDADE}

Desde o início, as diversas e distintas formas de ocupação da Amazônia, traduziu na violência, uma das suas principais características. Num cenário em perspectiva, uma violência que parece não ter fim, e que, no entanto, revela-se, pois, como um fenômeno reiterado, uma vez que estrutural. Nas origens, esta violência faz parte de uma estratégia inerente dos objetivos dos empreendimentos colonizatórios, concepção, aliás, mantida e, em grande parte, legitimada pelo Estado, seja quando ignora, seja quando "alimenta" tais formas de violência (Silva, 2010; Martins, 1985; Oliveira, 1988).

Neste sentido, para se ater no século XX, a emblemática situação de violência contra os índios Cinta Larga, no Parque Aripuanã, conhecida como "Massacre do Paralelo 11", patrocinada pela Companhia da Borracha do seringalista Antônio Mascarenhas de Junqueira, quando cerca de 3.500 índios Cinta Larga foram exterminados, em 1963. Em 2006, quando da ocorrência da morte dos garimpeiros, na Reserva Roosevelt, o jornal Estadão do Norte, de Porto Velho, comparando o histórico de conflitos no território indígena assim veiculou:

O conflito na Reserva Roosevelt, onde morreram 29 garimpeiros, foi um incidente de pequenas proporções se comparado ao Massacre do Paralelo 11, ocorrido em 1960, quando morreram cerca de 3.500 Cinta Larga, envenenados por arsênico. 'Esse assassinato em massa dos índios Cinta Larga foi cometido por pistoleiros a mando de empresários sem escrúpulos, com a cobertura de funcionários do então Serviço de Proteção ao Índio (SPI), entre eles o major da Aeronáutica, Luiz Vinhas Neves', lembra o indigenista Ulisses Capozzoli. O Massacre 
do Paralelo 11, como ficou conhecido um dos mais horrendos episódios de que se tem notícia até hoje no Brasil, incluiu do roubo ao estupro, passando por grilagem, assassinato, suborno, tortura e outras agressões que chocaram o então ministro do Interior, general Albuquerque Lima, que mandou demitir um dos principais envolvidos no incidente, o então chefe do SPI, major Luiz Vinhas Neves, responsável pela chacina dos Cinta Larga. Segundo Capozzoli, fazendeiros, com ajuda de funcionários do SPI, presentearam os índios com alimentos misturados a arsênico, veneno letal. "Em algumas aldeias aviões atiraram brinquedos contaminados com vírus da gripe, sarampo e varíola", recorda o indigenista, que considera o Massacre do Paralelo 11 como um dos mais sangrentos confrontos acontecidos nas matas da Amazônia brasileira. Os pistoleiros, liderados por Chico Luiz, a mando do seringalista Antônio Mascarenhas de Junqueira, invadiram a reserva indígena, armados de metralhadoras e winchester-44 ("papo-amarelo"), arma de alto poder de fogo, além de pistolas 38. "Os índios não tinham como se defender sob a fuzilaria deflagrada pelo disparo de Ataíde, mas o grupo só atravessou o rio quando se deu conta de que todos estavam mortos”, acrescenta Capazzoli (Estadão do Norte, 2006).

Aborda também este registro histórico o antropólogo e ativista cultural Shelton Davis (1977), relacionando o referido massacre dos “Cinta Larga” à questão dos "valiosos depósitos minerais”, encontradas em seu território, motivo principal da tentativa de dizimação da tribo. A linha de continuidade de tal violência, muitas vezes ocultada, amplifica-se no tempo e no espaço. O contato então se torna extermínio, "fratura exposta" de uma violência que faz vítimas apenas de um lado, os povos indígenas, depois os demais povos tradicionais e os camponeses. $\mathrm{O}$ resultado destas diferentes formas de violência, registra a extensão do envolvimento cúmplice entre Estado e iniciativa privada, que retrata, sob a lógica do desenvolvimento, a destruição territorial das comunidades originárias, o desmatamento, como formas sistêmicas desta violência padronizada. Tal quadro, retrata, enfim, as consequências inescondíveis do perverso processo de colonização da região amazônica.

Quando Vincent Carelli conseguiu terminar e publicar o filme Corumbiara, retratando a trágica sina dos índios Kanoê, dos índios 
Terra, poder e território em Rondônia: processos históricos, interesses e perspectivas

Akuntsu e do "índio do buraco" (Corumbiara, 2009), no espaço temporal de vinte anos (1986-2006), o que se testemunhou foi justamente as pegadas deste rastro de violência, onde sujeitos/agentes (Estado, grileiros, indígenas), em contexto determinado (omissão, grilagem e resistência), evidenciavam, sem nenhum "jogo de cena” ou representação, a tragédia dos vencidos. Afinal, isso só retratava o que a redescoberta do “Relatório Figueiredo" (2013), desvelaria à Comissão da Verdade, sobre o quadro histórico de violência contra os povos indígenas ${ }^{5}$.

Em relação às comunidades quilombolas, no Estado de Rondônia, a marca principal da violência consigna-se pela invisibilidade mantida e sustentada. Antes de tudo, esta violência é institucional, uma vez que o reconhecimento social destas comunidades está intimamente relacionado ao reconhecimento formal e à titulação, instrumentos às mãos do Estado, negado, entretanto, por sucessíveis artimanhas burocráticas e administrativas. A ideia de legalidade, infelizmente, mina o campo da autonomia e da soberania de tais povos, ainda que, amparados por Tratados e Convenções Internacionais ${ }^{6}$, e que as exigências da consulta e do consentimento livre, prévio e informado, sejam pressupostos da relação dos povos tradicionais em situação de contato.

Quanto aos dramas vividos pelas comunidades tradicionais, extrativistas e seringueiros, a violência originária perpetua-se em um contexto em que governos federal e estadual, por meio de suas instituições, insistem em desconhecer, negar e tardar a efetivação de seus direitos, ainda que legalmente amparados. Adiciona-se a coalisão desta

\footnotetext{
${ }^{5}$ Depois de 45 anos desaparecido, o Relatório Figueiredo, que apurou matanças de comunidades inteiras, torturas e toda sorte de crueldades praticadas contra indígenas em todo o país - principalmente por latifundiários e funcionários do extinto Serviço de Proteção ao Índio (SPI) -, ressurgiu quase intacto em abril de 2013. Supostamente eliminado em um incêndio no Ministério da Agricultura, ele foi encontrado no Museu do Índio, no Rio de Janeiro, com mais de 7 mil páginas preservadas e contendo 29 dos 30 tomos originais. Entre denúncias de caçadas humanas promovidas com metralhadoras e dinamites atiradas de aviões, inoculações propositais de varíola em povoados isolados e doações de açúcar misturado a estricnina - um veneno -, o texto, redigido pelo então procurador Jader de Figueiredo Correia, deve ser analisado agora pela Comissão da Verdade, que apura violações de direitos humanos cometidas entre 1946 e 1988.

${ }^{6}$ Convenção 169, da OIT, Declaração das Nações Unidas sobre os Direitos dos Povos Indígenas.
} 


\section{Geografias de Rondônia: Território, Fronteira e Educação}

inação estatal às organizações e corporações de grileiros, madeireiros e pecuaristas contra as comunidades extrativistas ${ }^{7}$.

Quanto aos camponeses, no Estado de Rondônia, a violência estrutural, como componente histórico, também se evidencia. De 1985 a 2016 foram 126 trabalhadores assassinados em situação de conflito agrário no Estado. Em relação à tipologia ou natureza desta violência, 36 casos ocorreram em razão da luta pelo acesso à terra, 30 por situações relacionadas à posse da terra e 24 , por situação em que a vítima era liderança de organização ou movimento social ${ }^{8}$.

Ainda que, com todo suporte institucional, o Projeto de Colonização da Amazônia, pretendendo fazer da experiência de Rondônia um evento exitoso, a não ser pela ocultação dos fatos, evidenciou-se como um processo que andou na contramão dos discursos oficiais e oficiosos. A desconstrução desta armadilha, que institucionalmente verbaliza o Estado de Rondônia como "terra de oportunidades", faz-se necessária. De forma inequívoca, principalmente nos efeitos sociais devastadores, a colonização de Rondônia oportunizou sim, uma premeditada tendência à privatização de terras públicas, de institucionalização da grilagem destas mesmas terras, de apropriações indébitas e mercantilizadas dos bens da natureza, vinculadas aos projetos agropecuários, à expansão do agrobusiness e a dilapidação da natureza, seja no solo, seja no subsolo da região.

Por isso que, diante da violência concreta, visível, que consumaria o controle da propriedade da terra e da exploração das florestas, dos rios e do subsolo, na especulação e na grilagem, impôs-se também a

\footnotetext{
${ }^{7}$ Conforme recente relatório divulgado pelo Grupo de Trabalho sobre Defensores de Direitos Humanos (2016), do Conselho Nacional de Direitos Humanos, "a violência e ameaça é uma prática corriqueira para impedir que as comunidades se organizem e lutem por seus direitos. Nos últimos 10 anos, 16 assassinatos de lideranças extrativistas foram registrados na região".

${ }^{8}$ Dados extraídos dos Relatórios anuais da Comissão Pastoral da Terra, que documenta e registra, anualmente, estas situações de violência, em âmbito nacional. Assume esta tarefa, tanto sob perspectiva teológica, mas também sob perspectiva ética, política, pedagógica, histórica e científica. O registro de dados cumpre assim uma tarefa de desvelamento da situação dos camponeses, mas também da realidade do campo, da intervenção ou omissão dos agentes estatais, das tendências e das políticas adotadas, assim como a dimensão da resistência deste componente histórico e inacabado que é a questão da terra e território no Brasil. Os dados e sua análise interpretativa, podem ser encontrados na página da Comissão (www.cptnac.org.br).
} 
Terra, poder e território em Rondônia: processos históricos, interesses e perspectivas

violência simbólica, como estratégia de Estado. Esta violência obedece a uma ordem estratégica. Ela pode ser encontrada nos aparatos jurídico-instituintes, como a defesa do Estado de Direito na defesa da propriedade, pode ser imposta enquanto burocracia estatal-legislativo, como forma de obstaculizar reconhecimento e acesso a direitos, como pode se dar sob na retórica da criminalização. Neste campo, seja "enunciando" e "categorizando" a luta dos movimentos sociais como ação criminosa, vandalismo, etc., seja mantendo impune e imune as ações violentas do latifúndio e da pistolagem contratada, a criminalização impõe o enquadramento dos movimentos sociais, atualmente referenciados penalmente, como "organizações criminosas" (CPT, 2021). ${ }^{9}$

A luta pelo acesso à terra, assim, reproduz e atualiza os padrões da violência da colonialidade, desvelando os equívocos do processo de colonização e fazendo emergir, nos limites do visível, as contradições próprias do modelo de desenvolvimento. À luz deste cenário constituído, é imprescindível constatar, contudo, que, o empreendimento institucional, sobretudo capitaneado pelo Estado, tem sido exitoso. Ora capturando e "domesticando" mentalidades dos pequenos posseiros e trabalhadores rurais, ora cooptando lideranças, organizações, em nome de um irreversível processo de desenvolvimento e projeto de futuro para a região. Insiste-se, entretanto, que se trata não de ocorrência pontual, mas de algo sistêmico e estrutural, de uma forma exógena de pensar o local, remanescida desde o início dos processos de colonização, mas implementada com maior ênfase a partir da década de 1970.

Analisando esta perspectiva da violência, em suas formas materiais e simbólicas, Guimarães Neto constata que:

Com os governos militares se consagra uma determinada política de ocupação da Amazônia que permite e mesmo legitima - por meio de instituições e dos novos mecanismos jurídico-legais - a invasão de territórios indígenas e áreas

\footnotetext{
9 Neste sentido, o texto e o contexto da Lei das Organizações criminosas (Lei n. 12.850/2013), constituindo, elementos de equiparação com as estratégias dos Movimentos sociais, e a mais recente, a Lei Anti-terrorismo (Lei n. 13.260/2016), abstraindo no conceito legislativo a possibilidade de enquadramento das práticas dos Movimentos sociais sem qualquer esforço exegético ("provocar terror social ou generalizado, expondo a perigo pessoa, patrimônio, a paz pública ou a incolumidade pública”).
} 
de posses de pequenos agricultores (posseiros), de seringueiros, entre outros segmentos sociais. Uma política que privilegia grandes e médios proprietários que são vistos como participantes do plano de desenvolvimento para a Amazônia e que, na prática, passam a atuar com a estrutura de governo para estabelecer os projetos de exploração econômica, sobretudo contando com estímulos financeiros dos incentivos fiscais. Neste quadro configura-se um processo de reterritorialização dos espaços, com políticas oficiais que se voltam para a classificação de diversas áreas, instituindo grandes eixos de investimentos econômicos, denominados "polos de desenvolvimento", com apoio do capital nacional e estrangeiro. Classificação de áreas vistas também como pontos estratégicos de intervenção política para atuar nos conflitos sociais (Guimarães Neto, 2014, p. 13).

Resta claro, assim, que o agente territorial público, ou seja, o Estado, em suas formas de atuação, repropõe um novo sentido para o espaço territorial em Rondônia. Esta nova "geograficidade" necessitará negar a história, para dar lugar aos novos processos econômicos inerentes ao avanço do capital na região. Elabora-se assim, uma nova construção social, por vezes até sem sujeitos sociais ou identidade social definida, em função de um alcance e projeto maior, nem sempre revelado.

Quanto a esta produção de sentido social, em regra, constata-se, na Amazônia, uma atitude muitas vezes de rejeição "ao que chega", ao que "vem de fora". Este é, em grande parte, o que ocorreu no Acre, onde o sentimento de "acreanidade" 10 ainda continua muito presente. No caso de Rondônia, em virtude da intensa migração do centro-sul do país, isso se dilui (Allegretti, 2002). A questão da mobilidade, ainda que não haja aqui espaço para este debate, é um componente que ultrapassa os limites da análise. Não está somente ligado a processos econômicos sob a embalagem do discurso proprietário. Vai além e se reveste, seman-

${ }^{10}$ Conceito trabalhado por Allegretti (2002), que traduz uma atitude cultural, sob forma de um sentimento de pertença, que se estrutura muitas vezes em termos de representação econômica e política das famílias tradicionais (elite local). Insere-se, neste contexto, também, atitude de rejeição à cultura e pessoas consideradas "de fora”, seja de outros estados do país, seja de outros países. Para a autora, este sentimento não ocorreu no estado de Rondônia. 
Terra, poder e território em Rondônia: processos históricos, interesses e perspectivas

ticamente, de contornos relacionados ao desenraizamento e da desterritorialização, incidindo e motivando inclusive intensos fluxos migratórios. Por outro lado, se tomar em consideração a composição social e política dos primórdios da ocupação e da colonização da região, houve, em muito, uma inversão na origem cultural das próprias camadas dirigentes e elite local, com a perda de representatividade econômica e política das famílias tradicionais.

A negação deste sentimento de pertença, no caso de Rondônia, ajuda em muito a compreender alguns processos, ao mesmo tempo que aprimora uma lógica de assimilação de experiências e modelos de produção oriundas "de fora" do Estado. Talvez, por isso, e pelo destino geográfico interligado, em muito corresponde, no plano do desenvolvimento econômico e produtivo, a reprodução em Rondônia do que ocorre no Mato Grosso, por exemplo. A opção pelos monocultivos, o alto preço da devastação ambiental, são vistas como políticas a serem "imitadas" em Rondônia, uma vez que lidas como experiência que "deram certo".

Reedita-se assim, hegemonicamente, um modelo de ocupação territorial exógeno, baseado numa percepção externa ao território, reconstituindo relações simétricas com base em anteriores experiências ao mesmo tempo que reproduzindo, em larga escala modelos ou projetos externos para o desenvolvimento local. Esta mentalidade facilmente pode ser constada nos investimentos públicos em infraestrutura, nas iniciativas privadas centradas no agronegócio e na ressurgida retórica da integração regional e agora, internacional.

\section{RONDÔNIA DAS ESTRADAS E RONDÔNIA DOS RIOS}

É possível, pois, falar que a ocupação do espaço geográfico da região, obedeceu por um longo período as características da natureza. Eram os rios as verdadeiras vias de interiorização e integração. Pode-se falar então da "Rondônia dos rios", como característica da região que perdurará até os inícios da década de $1960^{11}$.

\footnotetext{
${ }^{11}$ Sobre este tema, embora com algumas críticas que se possa fazer, há autores que optam em estabelecer uma classificação espaço-temporal, dividindo a Amazônia em: Amazônia dos Rios, Amazônia das Estradas, Amazônia das Regiões e Amazônia das Políticas. Neste sentido Cf: Sayago, Tourrand, Bursztyn, 2004.
} 


\section{Geografias de Rondônia: Território, Fronteira e Educação}

Nota-se que a região Amazônica, de forma geral, incorpora em sua dinâmica espacial, não um, mas diversos ecossistemas, como também não só um povo, mas diversos povos que formaram a chamada ocupação tradicional, construindo e mantendo esta característica até os anos 70. Isso é importante, pois ao considerar as várias fases do processo colonial percebe-se, em via de regra, um desconhecimento desta realidade natural. Seja nas "explorações coloniais europeias" do século XVI, nas "Entradas, Bandeiras e Monções", da época do império-colônia"12, ou ainda os programas estatais estimulados dirigidos do fim do século XIX (ciclo da borracha), ou do fim do século XX (fronteira agrícola), a região é tomada como um sistema natural único, o que causará sempre e também, um enorme impacto ambiental.

Repete-se nos processos de autocolonização a mesma lógica colonial, tendo também o mesmo pressuposto. Na obra de Gilberto Freyre, importante o retrato desta situação:

Tendo por base física as águas, ainda que encachoeiradas, dos grandes rios, prolongou-se no brasileiro a tendência colonial do português de derramar-se em vez de condensar-se. O bandeirante, particularmente, torna-se desde os fins do século XVI um fundador de subcolônias. Ainda não é dono da terra em que nasceu, mas simples colonial e já se faz de senhor das alheias em um imperialismo que tanto tem de ousado quanto de precoce. Com o bandeirante o Brasil autocoloniza-se (Freyre, 1980, p. 120).

A pesca, a caça e a coleta, atividades características dos povos tradicionais (indígenas, ribeirinhos, seringueiros, remanescentes de quilombolas, entre outros), retratam a Amazônia dos rios e das matas. Para os grandes projetos públicos e privados, sob a lógica desenvolvi-

\footnotetext{
12 Trata-se das diversas expedições à época do Brasil Colônia, com distintos objetivos, mas todos com finalidade econômica: exploração do território, busca de riquezas, captura dos índios para serem escravizados ou mesmo expedições de extermínio, etc. As entradas eram financiadas pelo governo colonial e em nome da Coroa, as Bandeiras eram iniciativas particulares. As Monções, eram expedições fluviais, com a finalidade de abastecer as áreas de mineração no Mato Grosso, mas também, sobretudo no Amazonas, visavam a extração das "Drogas do Sertão", especiarias a serem levadas para o consumo europeu. Muitas das Monções visavam também a captura dos índios.
} 
Terra, poder e território em Rondônia: processos históricos, interesses e perspectivas

mentista, tais povos não contam. Desenvolvem atividades econômicas de baixa produtividade, geram poucos impostos e desperdiçam grandes áreas que poderiam ser ocupadas por empreendimentos nacionais ou multinacionais.

Lima e Pereira refletem sobre este aspecto e de como, nesta transição os povos tradicionais vão se tornando ausentes e "invisíveis" dos programas governamentais e da visão do progresso econômico:

Mediante essas pressuposições, as populações tradicionais tornaram-se "invisíveis" no conjunto das políticas públicas, por não serem tratadas como atores sociais importantes nesse processo de desenvolvimento e mudança. Foi, aliás, graças a essa "invisibilidade" que os espaços por elas ocupados nos projetos oficialmente financiados apareciam como sendo um "vazio demográfico" passível de ocupação por outros atores externos à região, entre os quais se incluíam não apenas empresários, mas também populações pobres vindas de diferentes lugares do país, em especial do sul (de onde eram e continuam sendo expulsas para dar lugar à agroindústria em expansão e destinada à exportação) e do nordeste (seco e pobre). (Lima; Pereira, 2007, p. 112).

Ao longo de mais de 400 anos a ideia de assegurar as fronteiras territoriais pela ocupação do espaço físico, garantir a soberania, seja portuguesa, seja brasileira e ampliar a exploração de riquezas, ditava o texto e o discurso das grandes expedições. Tudo pelo ouro, pelas "drogas do sertão", pela borracha, e pela soberania, se for o caso. No entanto, a partir da década de 1950, a ideia de integração nacional começa a ganhar força. E como "bom motivo", a mesma, de sempre, premissa do progresso econômico.

Desta forma, inverte-se a perspectiva. Para resolver os problemas sociais e econômicos da região Amazônia, será importante pensar o desenvolvimento regional, esta era a crença e o discurso que ressoava entre políticos e intelectuais àquelas alturas. A Rodovia Belém-Brasília começa a ser construída em 1957. A Rodovia transamazônica começa a ser construída em 1970, se propondo a ligar extremos do País, da Paraíba ao Acre. A Rodovia Cuiabá-Santarém, começa a ser construída em 1973. A Rodovia que liga Manaus a Boa Vista, iniciada sua cons- 


\section{Geografias de Rondônia: Território, Fronteira e Educação}

trução em 1967 levará 10 anos para ser concluída. A Rodovia ligando Cuiabá-Porto Velho-Acre começou a ser construída no início dos anos 60. É a Amazônia das estradas avançando sobe a Amazônia dos rios mudando para sempre sua configuração (Carneiro Filho; Souza Filho, 2009).

A linguagem da época era carregada do espírito desenvolvimentista e embalada pela expressão "progresso", bem ao gosto dos militares que sempre insistiram em rimar segurança com ordem e civilização com progresso. Caminho aberto para os "novos bandeirantes", as "sentinelas avançadas", ou os "desbravadores", como sugeria o Estatuto da Terra de $1964 .{ }^{13}$ Mas, desde sempre, seriam os colonos, a colonizar novas terras e ocupar as fronteiras. A fase de colonizar mais que sucede à de conquistar, lhe é inerente. Nesta nova etapa de avanço do capital sobre a Amazônia será o Estado o planejador e o executor do processo de expansão econômica na região. Uma realidade cabia na teoria, outra coisa seria a prática. O discurso da terra aos sem-terra e da integração por medo da perda das fronteiras foi, na verdade, a "senha de segurança" para que Grandes Projetos, sobretudo privados, para que pudessem ser instalados na região, sob a legitimação estratégica dos projetos de colonização dirigida.

Neste sentido, as belas metas que visavam orientar as migrações para a Amazônia, eram o contra-ritmo da mesma composição. Para Rosa Elisabeth Marin, pois, "No mesmo tempo, instalam-se na região os grandes projetos agropecuários contando inclusive com forte incentivo fiscal, e que, na década, consumiram o triplo dos recursos destinados à colonização" (Marin, 2004, p. 18).

Nesta Amazônia das estradas, portanto, muda-se a face da Amazônia, causando um impacto sem proporções a partir dos fins da década de 1960. Ao lado dos grandes projetos de colonização concebidos, sobretudo para a potencialização dos empreendimentos agropecuários na região, inicia-se a implantação dos Grandes Projetos minerários. Assim, aumenta a pressão sobre o potencial de recursos naturais desencadeando-se inúmeros conflitos territoriais na Amazônia. Esta realidade

${ }^{13}$ Lei n. 4.504/1964. Art. $11^{\circ}, \mathbb{S} 2^{\circ}$ Tanto quanto possível, o Instituto Brasileiro de Reforma Agrária imprimirá ao instituto das terras devolutas orientação tendente a harmonizar as peculiaridades regionais com os altos interesses do desbravamento através da colonização racional visando a erradicar os males do minifúndio e do latifúndio. (Grifo nosso). 
Terra, poder e território em Rondônia: processos históricos, interesses e perspectivas

agrava ainda mais a situação das formas de ocupações tradicionais exercidas pelos povos indígenas, ribeirinhos, seringueiros, entre outros. $\mathrm{O}$ extrativismo está ligado mais à floresta e não à terra como meio de produção. Pode-se perceber que na configuração da Amazônia das águas, a forma de ocupação territorial tem outra dimensão diferente e oposta da apropriação do território (Amazônia das Estradas), com base na propriedade privada e onde o negócio imobiliário é que caracteriza tal impulso (Little, 2002).

No bojo dos Programas de Integração Nacional (PINs), a anunciada estratégia de valorização da região pelos investimentos em "desenvolvimento regional" vai acoplando-se à outra estratégia de integração econômica nacional e internacional. A construção das estradas seria o elo desta estratégia viabilizando a expansão territorial dos grandes empreendimentos agropecuários e comércio imobiliário de terras. Por outro lado, sob a orientação do Estado, a implementação de Grandes Projetos voltados para a exploração de recursos minerais em escala industrial e com presença hegemônica do capital internacional, transformaria a Amazônia numa moderna colônia energético-mineral (Marques, 2012).

A projeção de uma malha viária para viabilizar os projetos de colonização serviu prioritariamente para a consolidação do latifúndio na Amazônia, para os esquemas de monopólio e cartel imobiliário das terras e para o instituto da grilagem de terras na região. Em muitos casos, portanto, a "política das estradas", tiveram efeito adverso ao prometido para os colonos desterrados e atraídos para os projetos de colonização na Amazônia. Para os povos indígenas, o texto de sempre, agora num novo contexto: territórios invadidos por fazendeiros, comerciantes de madeira ou de espécies de alto valor para a moderna biotecnologia (Marin, 2004, p. 23).

Rosa Elizabeth analisando tal fenômeno, visualiza o confronto entre a "civilização dos rios e a civilização das estradas", em que o deslocamento de milhares de famílias do centro-sul para o norte do Brasil traduziu-se, sobretudo numa realidade de conflitos de terra, uma das expressões mais marcantes e resultado deste modelo de desenvolvimento:

(...) de um lado, uma intervenção que transforma a fronteira física da Amazônia em uma fronteira sociológica; e, de outro, o controle exercido por projetos e instâncias do governo (a 
exemplo do Incra) que se distanciam da colonização dirigida e defende a colonização privada, relutando em apoiar a colonização de massas e a expansão da fronteira (Marin, 2004, p. 19).

Guardando certas reservas em relação à chamada "expansão da fronteira", modelo equivocado de colonização, há de se concordar com o sentido conclusivo da afirmação. Os benefícios da colonização dirigida e sua estrutura mirava um público privilegiado. As terras públicas (devolutas) e a política de incentivos fiscais eram "reservas de motivo" para os empresários do sul do Brasil que poderiam assim desmatar grandes áreas para formar grandes fazendas. Neste cenário a lógica do "mercado de terras", dinamizou a especulação imobiliária credenciando a grilagem como "constituto" proprietário. E, em sede final, implementou-se os grandes polos industriais e, principalmente, como já anotado, os grandes programas de mineração, principalmente no lado Leste amazônico (Pará, Maranhão e Amapá).

Em meados da década de 1960, os militares incorporam a ideia do desenvolvimentismo, precisava lhe dar a tradução. Organiza-se então a chamada "Operação Amazônia" (1966-1970), visando atrair tanto as empresas nacionais e principalmente o capital internacional. Essencial para os projetos pensados, o governo visava também assegurar sua base de coalizão, sob o signo da doutrina da Segurança Nacional e do Desenvolvimento. Neste caso, a lógica da "intervenção interna” ganharia ares de nacionalismo, de demarcação das fronteiras e do progresso econômico. Neste sentido:

Com base numa avaliação de que dinâmicas decorrentes da estruturação da sociedade local eram responsáveis pelo atraso da economia regional e, ao mesmo tempo, que os atores locais seriam incapazes de se converterem em elementos propulsores de processos de desenvolvimento regional, os governos militares decidiram "ocupar" a Amazônia, atraindo para a região o empresariado "inovador" do Centro-sul ou mesmo do exterior (Monteiro, 2004, p. 103).

A contrapartida estatal seria a criação de uma série de Programas de incentivos financeiros e fiscais, "arranjos normativos" para facilitar processos de concessão de terras e licenças de exploração mineral, implementação de uma série de órgãos e instrumentos (infraestrutura) e 
Terra, poder e território em Rondônia: processos históricos, interesses e perspectivas

fomentos à atividade da colonização. O caráter "sagrado" desta empreitada reedita o discurso da "missão civilizatória", agora sob a toada do desenvolvimentismo. Um evento simbólico neste sentido, deu-se por ocasião da reunião que marcou o início da "Operação Amazônia", sinalizando justamente a transição desta Amazônia dos Rios para a Amazônia das Estradas e dos Grandes Projetos. A reunião ocorreu a bordo de um transatlântico, por nove dias pelo Rio Amazonas, em dezembro de 1966, onde se tomaram as decisões e se implementaram as adesões ao Projeto do Governo. Tal evento é assim contado por Márcio de Souza:

O transatlântico Rosa da Fonseca, fretado especialmente, saiu de Belém para Manaus levando a bordo um expressivo grupo de empresários internacionais, técnicos e funcionários governamentais. Desse passeio pelas águas do Rio Amazonas, uma estratégia foi montada, além da criação de um conjunto de instituições governamentais que ficariam encarregadas de planejar, gerenciar e coordenar as novas ações federais. Foram criados órgãos como o SUDAM, BASA, SUFRAMA e INCRA, através dos quais seus burocratas e técnicos movimentavam vultosos recursos e a ditadura militar numa só política o projeto de desenvolvimento com as ideias de ocupação e integração (Souza, 1977, p. 160).

Nas águas do Rio Amazonas delineia-se a Amazônia das Estradas e dos Grandes Projetos, por uma infeliz coincidência. Em resumo, nasce ali, na "Operação Amazônia" um sólido e completo sistema de colonização, definindo áreas, órgãos e estratégias de efetivação, não se esquecendo de expandir a iniciativa colonizadora para o setor privado, seja através do papel intermediário do comércio de terras para programas de colonização de médias e pequenas propriedades, seja na absorção de grandes áreas para fins de empreendimento rural (Santos, 1993).

\section{A SUSTENTAÇÃO JURÍDICA E OS DEBATES QUE ALICERÇAM A QUESTÃO}

Ainda que, no âmbito pós-Constituição de 1988 houvesse um contexto fértil de debates sobre "novos direitos", "novos sujeitos coletivos", territorialidade, "tradicionalidade das ocupações", a conjuntura, e, principalmente, as opções por programas neodesenvolvimentistas para Amazônia tratariam de impor obstáculos à efetivação de tais direitos. 


\section{Geografias de Rondônia: Território, Fronteira e Educação}

$\mathrm{Na}$ origem, o processo de colonização, entendidos por muitos, equivocadamente, como Programa de Reforma agrária, concretizou-se à custa de profundas violações, aqui já demonstradas. Em que pese, todas as questões estruturais abastecidas sucessivamente por programas e políticas de Estado e de governo, três grandes problemas se evidenciam: o problema da terra/território, o problema da floresta e o problema dos sujeitos históricos, ignorados e não reconhecidos. Apesar de interligados, estas questões desvelam interesses, muitos deles inconfessos. A questão da terra, na compreensão institucional atual, tem sido a questão da titulação ou da regularização. Restaura-se o princípio da "legalização fundiária", nome eficaz para a institucionalização da grilagem. Como no final do século XIX (Lei de terras de 1850), o enfoque aqui, é interditar ou impedir a legitimação da posse dos pequenos camponeses, dos povos que tradicionalmente ocupam as terras. A questão se resolve no papel, no título, na eficácia do contrato e no registro imobiliário. Uma "legalidade de papel", como saída legal para as profundas convulsões sociais no campo.

A questão da floresta, outro campo de disputa, reveste-se de um debate onde, ao lado dos interesses corporativos do avanço do capital na Amazônia, coexiste também uma lógica multilateral sob a narrativa do “desenvolvimento sustentável", da "governança global” e que envolve financiamentos e investimentos internacionais. Uma miscelânea engendrada por discursos ambientais exógenos, territoriais, programas de políticas compensatórias, etc. Um destes programas, acoplados ao projeto que deu sustentabilidade à colonização em Rondônia (Polonoroeste), foi o Programa Piloto ${ }^{14}$, sobrevivo ainda hoje.

É possível, pois, constatar que, a inserção política dos órgãos internacionais, dentro de uma lógica clara de "inserção dependente", configurou e consolidou, em muito, uma estratégia de amoldamento da região na concepção de globalização. Para tanto, utilizou-se do protago-

\footnotetext{
${ }^{14}$ Tal programa (Programa Piloto) ligado ao Banco Mundial foi proposto na reunião do grupo dos Sete países industrializados, em Houston, Texas (EUA), em 1990, e voltava-se para a proteção das Florestas Tropicais, mas sob o parâmetro da lógica do desenvolvimento ("desenvolvimento sustentável”). Os criadores e promotores do Programa Piloto ligaram o destino de sua iniciativa a uma ordem mundial pré-estabelecida à qual confiaram de maneira irrefutável a proteção dos recursos naturais na Amazônia, sem colocar minimamente em discussão a eficiência dessa ordem. Para mais informações conferir De Antoni, 2010, p. 301).
} 
Terra, poder e território em Rondônia: processos históricos, interesses e perspectivas

nismo de sujeitos locais e, sobretudo, de recursos, sob a forma de investimentos, atraindo ou capturando possibilidades de efetivação de uma política externa para a região. Neste sentido:

A globalização da Amazônia consiste então na extensão da regulamentação do mercado dentro de um espaço que, inicialmente protegido pelo princípio de conservação dos recursos naturais, foi convertido à lógica de mercado por meio das mesmas experiências de conservação implementadas. O PPG-7 contribuiu consideravelmente à construção desta nova fase: prestando todo o know-how necessário para gerenciar os serviços produzidos pelas florestas tropicais; graças à rede notável de comunidades, de grupos étnicos, de ONGs, de setores dos Estados da Amazônia que ficaram engajados, a linguagem e a cultura do mercado se tornaram mais familiares até os lugares perdidos da vasta região (De Antoni, 2010, p. 310).

A diferença entre aliança e cooptação, entre apoio e exploração, muitas vezes dissipa-se na linha tênue das retóricas. Assim também, os conceitos de corresponsabilidade internacional, de desenvolvimento sustentável, entre outros. No caso de Rondônia não há como não admitir que o Estado foi criado com recursos do Banco Mundial, sobretudo nos projetos de construção de estradas e colonização. E nisso, o Estado brasileiro foi o maior protagonista. Discutir, pois, a relação com o Estado na manutenção e amplificação dos mecanismos de desenvolvimento, é questão crucial. Diante das inúmeras tentativas de ordenamento fundiário, zoneamento, regularização e desenvolvimento regional, tangido pelo Estado, é de fundamental importância recorrer aos processos históricos e reparar nesta instrumentalidade estatal, a quem serve e que padrões ou modelos de desenvolvimento quer impor.

Significa o mesmo que analisar sobre quais recursos implementaram e sustentaram os índices de desenvolvimento? Quais interesses, servindo-se do aparelho estatal, incentivaram e contribuíram para o grau de reconcentração fundiária, especulação imobiliária junto com a "farra da grilagem institucionalizada"? Sob que argumentos e interesses, implanta-se, modifica e extingue áreas de proteção e conservação? Em que medida e a que fins os incentivos fiscais e patrocínio de obras de infraestrutura (rodovia, hidrovia, energia) estão vinculados? Sob qual 


\section{Geografias de Rondônia: Território, Fronteira e Educação}

perspectiva os modelos de desenvolvimento, regional são estabelecidos? A quem beneficia e que objetivo pretende?

Conforme Suyá Quintslr (2009), a Amazônia se caracteriza como uma arena onde estão em disputa concepções e projetos, que poderiam ser identificados em três grandes matrizes discursivas: a racionalidade econômica, do discurso desenvolvimentista e da mercantilização da natureza, por óbvio, corrente hegemônica; a racionalidade ecológica, do discurso preservacionista, e a racionalidade socioambiental, minoritário e que afirma e se sustenta sobre o valor da diversidade e justiça social. Portanto, é fundamental, no campo do diagnóstico e da análise, compreender os elementos subjacentes da racionalidade ambiental, pois são eles que determinarão, seja na perspectiva do empreendimento econômico, seja na luta por efetivação de direitos e reconhecimento. Neste sentido:

Ainda que o debate atual em torno da Amazônia se encontra fortemente polarizado entre concepções opostas de desenvolvimento e preservação, consideramos que a complexidade da questão ambiental na atualidade faz com que haja uma série de atores sociais defendendo diversas posições que vão muito além da dicotomia frequentemente evocada entre preservação e desenvolvimento econômico. De falto, o posicionamento dos atores sociais se encontra matizado pelas concepções referentes à relação entre sociedade e meio ambiente. Partimos do princípio de que o entendimento e a importância relativa dada por cada um desses atores a questões que concernem a essa relação irão determinar o seu posicionamento no espectro preservação versus desenvolvimento econômico e, em grande medida, as disputas em torno do tema, incidindo sobre as políticas que serão desenhadas e implementadas envolvendo o meio ambiente (Quintslr, 2009, p. 59).

A partir de tal pressuposto, os nomeados ciclos econômicos, as distintas concepções, seja "fronteira de expansão" ou "fronteira agrícola", as linhas de empreendimento do agronegócio (madeira, pecuária, soja), os projetos de infraestrutura (rodovia, hidrovia, energia), todos filtram-se por um modelo histórico de desenvolvimento e, portanto, por uma racionalidade econômica de sustentação política definida. Mas também, essa leitura aplica-se, em muito, às formas de resistência, seja 
Terra, poder e território em Rondônia: processos históricos, interesses e perspectivas

na adoção da instrumentalidade estatal, como solução dos problemas históricos, seja na própria concepção de organização e desenvolvimento a que os movimentos e organizações se inserem. Em perspectiva pendular, o Estado oscila neste território de disputa e instrumentalização, desvelando ou ocultando seu papel. É neste campo que o concreto às vezes se distancia do simbólico, muito embora as práticas se misturam aos discursos.

$\mathrm{Na}$ perspectiva atual hegemoniza-se a lógica do "expandir, desmatar e concentrar". Tal discurso emoldura-se no agro modelo, defendido à exaustão com a mesma retórica do progresso, do desenvolvimento ou da modernização. O "mercado do agro" e sua missão de salvamento da economia prepondera, ainda que claramente expansionista, concentrador e "desmatador". Pouco ou nenhum compromisso republicano envolve tal argumento. A apropriação do público, aliás, seja das terras públicas, das áreas protegidas e do subsolo, transforma-se em objeto de saque e pilhagem. Esta face de patrimonialismo, enfim, encontra no Estado e nos seus órgãos funcionais, uma recepção fantástica.

Este discurso, igualmente, se retroalimenta de forma harmoniosa com os sinais advindos do Congresso Nacional e assim, impõe-se uma agenda de retrocessos referentes às Unidades de Conservação, promove-se alterações legislativas para legitimar novas formas de concentração de terras, flexibiliza licenças ambientais e se precariza condições de vida e de trabalho dos camponeses. Sem falar, que, tal agenda, beneficia um setor econômico influente, que muito pouco possui de republicano: o campo do agronegócio. Claro, entretanto, que isso exige uma caução ideológica, uma justificação prévia. Por isso, os setores hegemônicos da economia, que são também setores hegemônicos na política, lançam e mantém uma campanha no sentido de capturar "corações e mentes", assegurando a legenda desta hegemonia. Mais que o fato, o importante é a versão.

À reiteração destas práticas, chama-se aqui de colonialidade. Este padrão instituidor da lógica capitalista, que se materializa na apropriação e mercantilização da natureza, no sequestro e privatização dos bens públicos, nas formas econômico-instrumentais de se pensar e explorar o meio ambiente. Em recorte específico, a colonização de Rondônia carrega consigo esta razão da colonialidade, planejada, dirigida e mantida para fins implícitos e evidentes. Na concepção de Oliveira: 
[...] todo o processo de ocupação da Amazônia tem representado uma usurpação dos territórios das nações indígenas, e este processo não foi realizado sem intencionalidade, ao contrário, era e é a estratégia geopolítica do confisco sumário pela força desses territórios e o enquadramento e redefinição das terras indígenas (Oliveira, 1993, p. 103).

E mesmo que a ideia de "função social" da terra ou da propriedade estivesse presente no Estatuto da Terra (Lei n. 4.504/1964), ou posteriormente guindada como diretriz na Constituição Federal de 1988, se mostrou insuficiente ante as demandas das dinâmicas patronais ou proprietárias dos projetos de colonização na Amazônia. Quer se dizer com isso que, historicamente, a ideia de posse, substantivada no trabalho, na moradia e na existência, poderia ser invocada como requisito de legitimação, inclusive dos direitos territoriais. No entanto, a propriedade assaltou a posse. Esta questão, crucial também para a Amazônia, traduz igualmente um campo de disputa. Márcia Maria Menendez Motta e Paulo Zarth analisam o cenário desta disputa:

Ainda hoje, quando um posseiro da Amazônia justifica seu direito à terra, ele o faz invocando o direito que teria sido gerado pelo trabalho na terra. Ao mesmo tempo, reclama e proclama que seu direito está referido aos frutos de seu trabalho, que por serem seus está no direito de cedê-los ou vendê-los. A concepção de que é preciso ocupar a terra com trabalho (na derrubada da mata e no seu cultivo) antes de obter reconhecimento de direito, era próprio do regime sesmarial. Do mesmo modo, a concepção de que o trabalho gera direito de propriedade sobre os frutos do trabalho também era própria desse regime fundiário. Nele, o domínio estava separado da posse. O domínio era da Coroa (Motta; Zarth 2008, p. 179).

No contexto estudado, o processo de colonização implantado e sustentado em Rondônia, em suas origens, desconheceu e anulou o direito da posse dos povos e comunidades tradicionais, em seus modos de vida e em suas relações de pertencimento territorial. A colonização dirigida, tão badalada pelos programas oficiais, cuidou de reservar grandes contingentes de terras, pelo instrumento de concessão e "alienação" de terras públicas a particulares do centro-sul do Brasil. Na narrativa 
Terra, poder e território em Rondônia: processos históricos, interesses e perspectivas

documental de Vincent Carelli (Corumbiara, 2009), esse procedimento foi delineado:

O sul de Rondônia é a frente de expansão da vez. A Gleba Corumbiara que é o "filé" da região, foi leiloada pelo Governo militar no final da década de 60 para empresários paulistas. Vários membros de uma mesma família arrematam um lote cada um e assim se formam os latifúndios. O governo gastou mais demarcando os lotes do que cobrava pelas terras. Os fazendeiros fizeram mais dinheiro vendendo madeiras do que pagaram pelos lotes.

E assim, também na colonização, a lógica proprietária, sob a tutela jurídica do Estado brasileiro, cuidará de assegurar duas importantes questões: a primazia do latifúndio, expropriando terras públicas e destinando à interesses privados, e a interdição de reconhecimento das ocupações "irregulares" dos camponeses, nestas mesmas terras, em muitos casos abandonadas. Quanto aos contratos e concessões, o mecanismo da "grilagem cartorial", reestruturará a lógica da dominialidade proprietária, útil e funcional à defesa e proteção judicial. Quanto às ocupações dos pequenos camponeses nestas terras, restará as liminares de despejo, a criminalização e a violência institucional ou privada das expulsões. Resolve-se assim, no âmbito civil, a questão proprietária, não importando a ilicitude das origens. No âmbito penal e policial, resolve-se a questão das ocupações e das posses. Caberá à jurisdição (Juris dictio), ou seja, o órgão estatal responsável de "dizer o direito", a "solução" da questão fundiária e, por assim dizer, a "dissolução" da questão pública da terra na Amazônia.

\section{CONSIDERAÇÕES FINAIS}

Há mais que um olhar e mais que uma perspectiva quando se busca analisar a questão socioterritorial no Estado de Rondônia. Não se sustenta mais a imposição das leituras homogeneizantes e muito menos a imposição do silêncio ou ocultamento dos processos históricos e sociais, da nossa formação. Assim, uma espécie de "hermenêutica da suspeita" ${ }^{15}$, diante das "coisas dadas", sobre determinadas e também naturalizadas se estabelece como pressuposto.

${ }^{15}$ Conceito elaborado pelo Filósofo Paul Ricoeur onde constata a necessidade de considerar na interpretação da realidade o clivo da suspeita. Isto, é, para além dos "consensos 


\section{Geografias de Rondônia: Território, Fronteira e Educação}

Remete-se, portanto, a este primeiro elemento de necessária desconstrução das narrativas institucionais. Os fatos desmentem as narrativas, mesmo porque os fatos se movimentam e revolvem "perigosamente" o chão retórico dos discursos. Ao retrato, muitas vezes frio, dos dados ou estatísticas, há que inserir a existência dos sujeitos, ocultados, silenciados, invisibilizados. Mesmo no silêncio há uma linguagem e muitas vezes sob a forma de denúncia. Com isso, aponta-se para além da realidade dos processos, a concretude destes sujeitos históricos e coletivos, que nos dias de hoje ainda se sentem convocados a mobilizações por direitos e por reconhecimento.

Mas também, sem a pretensão de suficiência, a presente análise remete a um olhar e a um exame mais atento dos discursos e das narrativas. Há, na tentativa de impor consensos, uma insistente postura epistêmica de colonialidade, traduzida em continuidade e diluída na retórica sofisticada do desenvolvimento, da oportunidade e da vanglória. A descolonização necessária, do pensamento, do olhar e da análise, como exercício permanente, é assim, um imperativo imprescindível.

A questão fundiária e territorial em Rondônia revela-se como um feixe emblemático de situações e relações. Proposta e imposta sob a tutela ideológica do desenvolvimentismo, a lógica estatal, ainda hoje, insiste em desconhecer, interditar e revogar direitos, ainda que, de alguma forma, assegurados. Os movimentos de resistência, por sua vez, reclamam visibilidade e insistem em ultrapassar barreiras e superar tantos interditos.

Entre equívocos e novos enredos, a história e o processo de colonização de Rondônia desvelam uma composição de pessoas e lugares. Há bastidores, palco e público, mas há também "silêncios", guerra e sofrimento. Há vítimas, "supostos" heróis, e tem havido, por certo, resistência das comunidades, das organizações e dos movimentos sociais. Mas, é do lugar de onde se olha, que a fala se produz, e por vezes, se reproduz. Assim, é na descolonização do olhar, do pensamento e da fala, que se tornará possível e imprescindível as ações de mudança e transformação necessárias.

impostos", numa perspectiva de (des)construção e (des)colonização dos sentidos, produzidos e, às vezes mantidos no e pelo imaginário coletivo, faz necessário suspeitar, para chegar ao conhecimento real. Ricoeur, Paul. O conflito das interpretações. Tradução de Hilton Japiassu. São Paulo: Imago, 1978. 
Terra, poder e território em Rondônia: processos históricos, interesses e perspectivas

\section{REFERÊNCIAS}

ALLEGRETTI, Mary Helena. A construção social de políticas ambientais - Chico Mendes e o Movimento dos Seringueiros. Tese de Doutorado, defendida junto ao PPG da Universidade Nacional de Brasília - Centro de Desenvolvimento Sustentável, 2002.

BALDI, César Augusto. Novo constitucionalismo latino-americano: considerações conceituais e discussões epistemológicas. In: Wolkmer, Antonio Carlos; Correas, Oscar (Organizadores). Crítica jurídica na América Latina, México, 2013, p. 90-207.

BECKER, Berta K. Amazônia. São Paulo: Ática, 1990.

CORUMBIARA. Direção de Vincent Carelli. Estúdio: Vídeo nas Aldeias. Brasil, 2009.

CARNEIRO FILHO, Arnaldo; FILHO, Oswaldo Braga de Souza. Atlas de pressões e ameaças às terras indígenas na Amazônia brasileira. São Paulo: Instituto Socioambiental, 2009.

CPT. Comissão Pastoral da Terra. Conflitos no Campo Brasil, Goiânia, 2021. Disponível em: www.cptnacional.org.br/publicacoes-2/conflitos-no-campo-brasil. Acesso em: 20 nov. 2021.

COSTA, Gleimiria Batista de. Permanência de práticas tradicionais em Reservas extrativistas no Estado de Rondônia. Orientadora: Helena Ávila Campos. 2012. Tese (Doutorado em Desenvolvimento Regional). Universidade de Santa Cruz do Sul - UNISC/RS. Santa Cruz do Sul, 2012.

CUNHA, Euclides da. Um paraíso perdido. Rio de Janeiro: Ed. José Olympio, 1994.

CIMI. Panewa Especial, Porto Velho, 2015.

DARDEL, Eric. O homem e a terra. São Paulo: Perspectiva, 2011.

DE ANTONI, Giorgio. O Programa Piloto para Proteção das Florestas Tropicais do Brasil (PPG-7) e a globalização da Amazônia. In: Revista Ambiente \& Sociedade. Campinas v. XIII, n. 2, p. 299-313, jul.-dez. 2010.

ESTADÃO DO NORTE. "Massacre no Paralelo 11 extermina 3.500 índios”. Porto Velho, 10.02.2006. Disponível em: https://pib.socioambiental.org/en/noticias?id=17879. Acesso em: 20 nov. 2021. 
FAJARDO, Raquel Z. Yrigoyen. El pluralismo jurídico en la historia constitucional latinoamericana: de la sujeción a la descolonización. 2012. Disponível em: http://6ccr.pgr.mpf.gov.br/destaques-do site/3_ RYF_2010_CONSTITUCIONALISMO_Y_PLURALISMO_BR.pdf Acesso em: 20 Jul. 2017.

FREYRE, Gilberto. Casa Grande e Senzala. Rio de Janeiro: José Olímpio, 1980, p. 120.

GUIMARÃES NETO, Regina Beatriz. Violência e trabalho na Amazônia: narrativa historiográfica. In: Revista Territórios \& Fronteiras. v. 7, n. 1. Cuiabá, abr. 2014, p. 13.

IANNI, Octávio. Colonização e contra-reforma agrária na Amazônia. Petrópolis: Vozes, 1979.

LIMA, Marta Goreth Marinho; PEREIRA, Elves Marcelo Barreto. Populações tradicionais e conflitos territoriais na Amazônia. In: Revista Geografias. Belo Horizonte, v. 3, n. 1, p. 107-119, jan./jun. 2007.

LITTLE, Paul E. Territórios sociais e povos tradicionais no Brasil: por uma antropologia da territorialidade. Brasília, UnB, 2002. Série Antropologia 322.

MARIN, Rosa Elizabeth Acevedo. Civilização do rio, civilização da estrada: transportes na ocupação da Amazônia no século XIX e XX. In: I SITREAMA, 2004, p. 18. Disponível em: www.ufpa.br/naea/papers. php?mvitem=3. Acesso em: 15 maio 2012.

MARQUES, Gilberto. Amazônia: uma moderna colônia energético-mineral? In: Revista Universidade e Sociedade. Sindicato nacional dos Docentes das Instituições de Ensino Superior (Andes). Ano XXI n. 49, Brasília, jan. de 2012.

MARTINS, José de Souza. A militarização da Questão Agrária. 2. ed. Petrópolis: Vozes, 1985.

MONTEIRO, Maurílio de Abreu; COELHO, Maria Célia Nunes. As políticas federais e reconfigurações espaciais na Amazônia. In: Revista Cadernos NAEA, v. 7, n. 1, junho de 2004. Disponível em: www.periodicos.ufpa.br/index.pho/ncn/article/viewFile/38/32. Acesso em: 2 mar. 2012.

MOTTA, Márcia Maria Menendes; ZARTH, Paulo (orgs.). Formas de resistência camponesa: visibilidade e diversidade de conflitos ao 
Terra, poder e território em Rondônia: processos históricos, interesses e perspectivas

longo da história. São Paulo: Editora Unesp; Brasília: Ministério do Desenvolvimento Agrário, NEAD, 2008.

MURA, Fabio. O tekoha como categoria histórica: elaborações culturais e estratégias kaiowá na construção do território. In: Revista Fronteiras. n. 13, 2004. Disponível em: www.scielo.br/scielo.php?script=sci_ nlinks\&ref=000163\&pid=S0104-9313201000010000600023\&lng=en. Acesso: 23 maio 2015.

OLIVEIRA, Ariovaldo Umbelino de. Integrar para (não) entregar: políticas públicas e Amazônia. Papirus: Campinas, 1988.

OLIVEIRA, Ariovaldo Umbelino de. Amazônia: monopólio, expropriação e conflitos. Série educar aprendendo. São Paulo: Editora Papirus. 1993, p. 103.

OLIVEIRA, Ariovaldo Umbelino de. A longa marcha do campesinato brasileiro: movimentos sociais, conflitos, reforma agrária. In: Revista Estudos Avançados, v. 15, n. 43, São Paulo: set/Dez. 2001. Disponível em: www. scielo.br/scielo.php?script=sci_arttext\&pid=S0103-40142001000300015

PEDRIALI, José. Transamazônica: fracasso nacional. Folha de São Paulo, 25 de outubro de 2016. Disponível em: www.josepedriali.com. br/2016/10/transamazonica-fracasso-nacional.html.

QUINTSLR, Suyá. Amazônia: Disputas materiais e simbólicas. In: Revista Brasileira de Estudos Urbanos e Regionais, v. 11, n. 1, Rio de Janeiro, 2009.

RICOEUR, Paul. O conflito das interpretações. Tradução de Hilton Japiassu. São Paulo: Imago, 1978.

SANTOS, José Vicente Tavares de. Matuchos: exclusão e luta: do sul para a Amazônia. Tradução de Lúcia Mathilde Endlich Orth. Petrópolis: Vozes, 1993.

SAYAGO, Doris; TOURRAND, Jean-François; BURSZTYN, Marcel (Org). Amazônia: cenas e cenários. Brasília: Universidade de Brasília, 2004.

SCORZA, Manuel. História de Garabombo, o invisível. (Tradução de Glória Rodríguez). Rio de Janeiro: Civilização Brasileira, 1975.

SHETON, Davis H. Vítimas do milagre: o desenvolvimento e os índios do Brasil. Tradução de Jorge Alexandre Faure Pontual. Rio de janeiro: Zahar Editores, 1977. 
Geografias de Rondônia: Território, Fronteira e Educação

SILVA, Ricardo Gilson da Costa. Dinâmicas territoriais em Rondônia: conflitos na produção e uso do território no período de 1970/2010. 2010. Tese (Doutorado em Geografia Humana) - Faculdade de Filosofia, Letras e Ciências Humanas, Universidade de São Paulo, São Paulo, 2011. doi:10.11606/T.8.2011.tde-14092011-131342.

SOUZA, Márcio de. A expressão amazonense: do colonialismo ao neocolonialismo. São Paulo: Alfa-Ômega, 1977, p. 160.

SOUZA FILHO, Carlos Frederico Marés. O renascer dos povos indígenas para o direito. Curitiba: Juruá, 1998.

WOLKMER, Antônio Carlos; Leite, José Rubens Morato (Org.). Os "novos" direitos no Brasil: natureza e perspectivas. São Paulo: Saraiva, 2003 


\title{
Fronteira, Direitos Humanos e Territórios Tradicionais EM Rondônia (AMAZÔNIA BRASILEIRA) ${ }^{1}$
}

\author{
Ricardo Gilson da Costa Silva* \\ Amanda Michalski "* \\ Luciano Ítalo Tavares de Souza*** \\ Luís Augusto Pereira Lima****
}

\section{INTRODUÇÃO}

A partir da década de 1960, a Amazônia brasileira vem experimentando ordenamentos territoriais que produzem formas de apropriação e dominação do mundo rural, no qual a mercantilização da natureza e da terra compõem a lógica territorial do Estado (agências públicas) e das grandes empresas (mineradoras, hidrelétricas, agropecuárias, construtoras, madeireiras). Trata-se de projetar e formar territórios da socialidade do capital, que se expande para todas as sub-regiões amazônicas. Dados aos impactos sociais, ambientais e territoriais decorrentes de seis décadas da chamada modernização da Amazônia, a condição de fronteira não cessou com o processo de modelação da economia regional, ou seja, há uma contínua transformação de áreas naturais em espaço da agropecuária e do mercado de terras, que atualmente se desloca para os territórios protegidos.

\footnotetext{
${ }^{1}$ A pesquisa financiada pelas instituições: Fapero, Dhjus/Emeron, Capes e CNPq. Publicado em: COSTA SILVA, R. G. da; MICHALSKI, A.; SOUZA, L. I. T.; LIMA, L. A. P. Fronteira, direitos humanos e territórios tradicionais em Rondônia (Amazônia Brasileira). Revista de Geografia Norte Grande, n. 77, p. 253-271, 2020.

" https://orcid.org/0000-0002-3348-9629

"* https://orcid.org/0000-0003-0855-502X

*** https://orcid.org/0000-0001-6109-7828

**** https://orcid.org/0000-0003-0390-4315
} 


\section{Geografias de Rondônia Território, Fronteira e Educação}

Nesse processo, a contínua marcha do capitalismo na Amazônia brasileira atinge as Áreas Protegidas, espaços destinados à preservação, à conservação da natureza, e à proteção dos territórios tradicionais dos povos amazônicos (indígenas, seringueiros, ribeirinhos, quilombolas, extrativistas, dentre outros grupos). Essas dinâmicas territoriais agrárias ampliam as pressões sociopolíticas e econômicas nos espaços institucionalizados para garantir formas sociais de uso coletivo da terra e da natureza que diretamente assegura a proteção dos serviços ambientais à sociedade.

Pode-se verificar tais dinâmicas, de modo geral, em toda a Amazônia, desde as sub-regiões mais próximas dos centros econômicos radiadores, quanto nas áreas em que as estradas ainda não chegaram, cujo acesso se faz por barcos (Costa Silva et al., 2018). Desse modo, analisa-se esse fenômeno no estado de Rondônia, localizado na Amazônia meridional brasileira, problematizando os processos de invasões nos territórios dos povos indígenas e seringueiros (comunidade tradicional). Neste caso, aborda-se os processos modeladores da fronteira que se realizam no norte do estado de Rondônia, especificamente no município de Porto Velho, onde a Terra Indígena Karipuna, a Reserva Extrativista Jacy-Paraná e a Floresta Nacional do Bom Futuro sofrem as pressões de agentes econômicos traduzidas nas invasões de Áreas Protegidas, grilagens, desmatamento, extração madeireira e agropecuária.

Baseado nos fenômenos empíricos estudados, o objetivo deste texto é analisar a relação da expansão da fronteira, ordenamentos territoriais e direitos humanos em Rondônia, priorizando os sujeitos sociais aviltados em seus direitos mais básicos, ou seja, os grupos sociais que formam os povos e as comunidades da Amazônia, com especial atenção aos povos indígenas e aos seringueiros da área de estudo. Como procedimentos metodológicos, adotou-se o i) trabalho de campo e observação direta da área de estudo, ii) coleta de dados quantitativos (pecuária, desmatamento, extração madeireira) junto aos bancos de dados de instituições públicas (Instituto Brasileiro de Geografia e Estatística-IBGE e Instituto Nacional de Pesquisas Espaciais-INPE), os quais foram trabalhados com os iii) softwares Excel (estatística), Philcarto (cartomática) e ArcGIS (geoprocessamento). iv) A revisão bibliográfica priorizou os estudos regionais referentes aos grandes projetos de infraestrutura, expansão de fronteira e impactos sociogeográficos.

Assim, além desta introdução, o texto está dividido em três seções, seguido das considerações finais. Na primeira seção, analisa-se a expansão da fronteira e ordenamentos do território na Amazônia, pro- 


\section{Fronteira, Direitos Humanos e Territórios Tradicionais em Rondônia [Amazônia brasileira]}

blematizando a transformação da região em espaço nacional da economia extrativa, cujas dinâmicas econômicas atingem os territórios dos povos amazônicos. $\mathrm{Na}$ segunda seção, aprofunda-se o entendimento desse processo para o estado de Rondônia, evidenciando o crescimento da pecuária, extração madeireira, desmatamento, mercado de terra e agronegócio. Em seguida, na terceira seção, problematiza-se como a expansão da fronteira atinge os territórios tradicionais e Unidades de Conservação em Rondônia, priorizando a Terra Indígena Karipuna e a Reserva Extrativista Jacy-Paraná, na região do município de Porto Velho, capital do estado de Rondônia. Na quarta seção, de modo resumido, elenca-se alguns apontamentos para a pesquisa em geografia, direitos humanos e território, com vistas ao entendimento das lutas dos povos amazônicos na defesa de seus territórios frente às pressões e violências produzidas pelas forças do capital.

Conclui-se que a expansão da fronteira promovida pelos grupos econômicos (pecuaristas, madeireiros, grileiros, mineradoras e agronegócios), com apoio do Estado, afeta a proteção ambiental e cultural dos povos amazônicos com fortes transgressões às leis de ordenamento territorial, cujo resultado institui um processo social vinculado à violência, ao crime ambiental e a violação dos direitos humanos e territoriais dos grupos sociais diretamente afetados.

\section{AMAZÔNIA, FRONTEIRA E ORDENAMENTOS DO TERRITÓRIO}

Desde a década de 1960, a formação socioespacial da Amazônia vem passando por aceleradas transformações coordenadas pelo Estado brasileiro, que numa perspectiva geopolítica de ocupação humana e econômica instituiu processos de socialidade do capital no interior da floresta Amazônica, produzindo uma geografia do desmatamento e das agressões aos territórios tradicionais dos povos amazônicos. A abertura de estradas, migração e colonização agrícola, articulada aos grandes projetos de infraestruturas (mineração, energia, agropecuária) e expansão urbana, configuraram o que Raffestin (1993) qualificou de sistema territorial de poder do Estado. Esses grandes projetos conformaram os tentáculos do Estado na apropriação e dominação do território (Becker, 2004).

Nesse sentido, fronteira e ordenamento territorial foram conceitos mobilizados para compreender a ordem política, econômica e social que se impunha à Amazônia. Por fronteira, entende-se a expansão espa- 


\section{Geografias de Rondônia Território, Fronteira e Educação}

cial do capital em regiões periféricas, no qual a natureza e a terra são metamorfoseadas em mercadorias, a exemplo da Região Amazônica (Becker, 2004; Costa Silva, 2017; Kohlhepp, 2002; Mello; Théry, 2001). Assim, pode-se afirmar que há uma ordem territorial que reconfigura as funções econômicas e sociais da Amazônia no sentido de aprofundar a extração dos recursos naturais. Nesses termos, as dinâmicas territoriais que atingem o espaço agrário amazônico estão indissociavelmente articuladas às contínuas apropriações dos recursos naturais, evidenciando estratégias de territorialização dos grupos sociais (migrantes, colonos, camponeses), agentes hegemônicos (latifundiários, grandes empresas) e Estado (diversas agências estatais) que reproduzem a expansão da fronteira (Coy et al., 2017). Desse modo, contemporaneamente, ao tempo em que se expande a fronteira, pari passu, tem-se as pressões socioeconômicas em Áreas Protegidas (Unidades de Conservação, Terras Indígenas e Quilombolas), que tendem a gerar conflitos territoriais e expropriações dos grupos sociais mais vulneráveis, como os povos indígenas, seringueiros, ribeirinhos e quilombolas, além de outras comunidades tradicionais amazônicas (Figura n. 1).

Figura 1 - Mapa das Áreas Protegidas na Amazônia brasileira (2020).

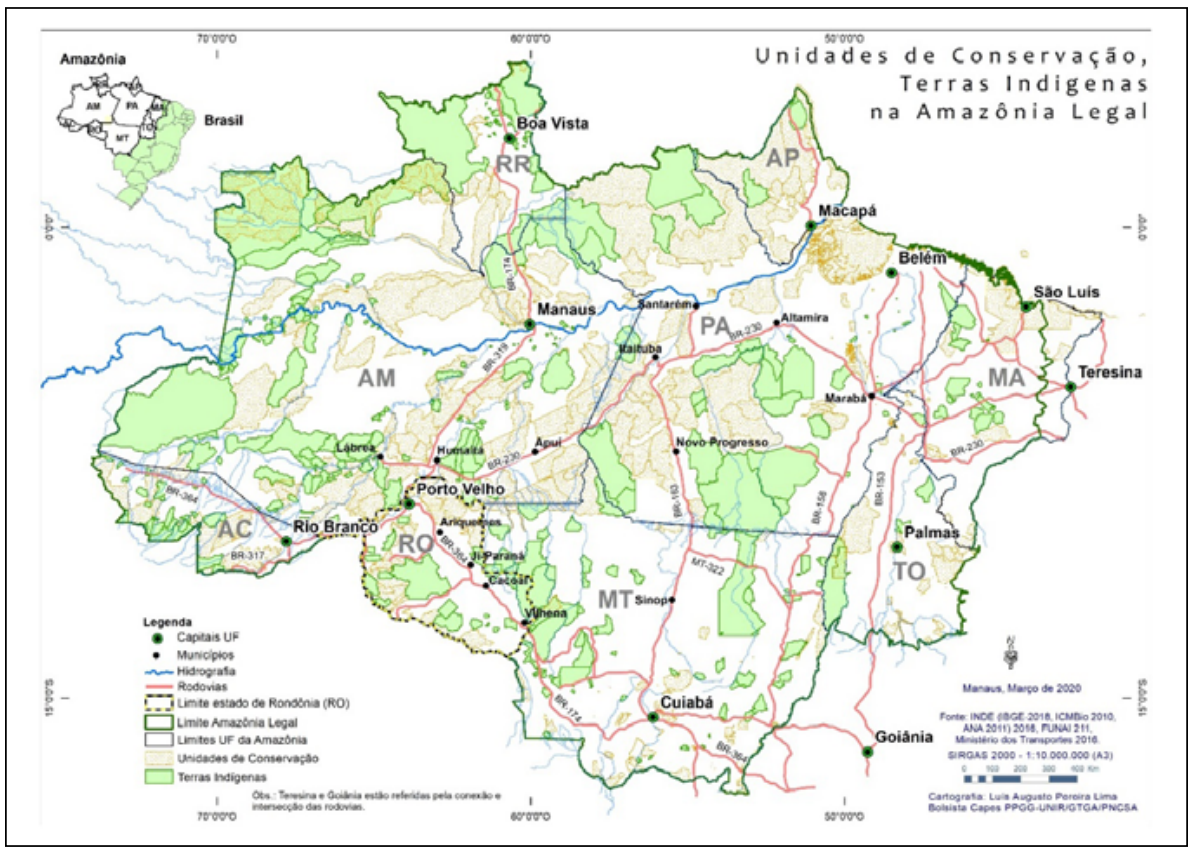

Fonte: Elaboração dos Autores. 


\section{Fronteira, Direitos Humanos e Territórios Tradicionais em Rondônia [Amazônia brasileira]}

Para Kohlhepp (2002), o processo de organização territorial na Amazônia apresenta duas categorias: a estatal e a privada. A primeira objetivou atrair investidores para a região Norte do Brasil, buscando promover projetos que pudessem colaborar com a melhoria da infraestrutura centralizada no transporte rodoviário. Tal medida tinha o intuito de legitimar a integração da região amazônica ao restante do país. A segunda, por meio de incentivos fiscais, efetivou-se nos megaprojetos de exploração agrominerais e agroflorestais. Esses processos, de modo geral, instituíram um ordenamento do território que expressou, e ainda expressa, a condição da Amazônia como fronteira de recursos, na medida em que sua função na divisão territorial do trabalho é a economia de produtos primários, ou com pouco valor agregado (Costa Silva ; Conceição, 2017). Qualificando o ordenamento territorial, Trindade Júnior e Madeira (2016, p. 37-38) propõem uma periodização das dinâmicas territoriais centrais que transformaram a Amazônia: "os polos de crescimento (até a década de 1980), os eixos de integração e desenvolvimento (a partir da segunda metade da década de 1990), [...] e os zoneamentos ecológicos-econômicos (a partir, principalmente, dos anos 2000). Kholhepp (2002) subdivide esses processos em seis fases (Quadro n. 1).

Quadro 1 - Fases de ordenamento territorial na Amazônia.

\begin{tabular}{|c|c|c|}
\hline Fase & Período & Objetivo \\
\hline $1^{a}$ & $\begin{array}{l}\text { Primeira metade } \\
\text { da década de } 1970\end{array}$ & $\begin{array}{l}\text { Construção de grandes rodovias / Transamazônica, a Perimetral } \\
\text { Norte, Cuiabá-Santarém e Cuiabá-Porto Velho-Manaus. }\end{array}$ \\
\hline $2^{a}$ & Entre 1974 e 1980 & $\begin{array}{l}\text { Implementação dos Programas de Polo Agropecuário e Agrominerais } \\
\text { da Amazônia (Polamazônia) }\end{array}$ \\
\hline $3^{a}$ & $\begin{array}{l}\text { Nos primeiros } \\
\text { anos da década } \\
\text { de } 1980\end{array}$ & $\begin{array}{l}\text { Implementação do Programa Integrado de Desenvolvimento do } \\
\text { Noroeste do Brasil (Polonoroeste) }\end{array}$ \\
\hline $4^{a}$ & Década de 1980 & $\begin{array}{l}\text { Megaprojetos minerais e agropecuários com destaque para o Projeto } \\
\text { Grande Carajás. }\end{array}$ \\
\hline $5^{\mathrm{a}}$ & $\begin{array}{l}\text { Início da década } \\
\text { de } 1990\end{array}$ & $\begin{array}{l}\text { Organização e implementação do Programa Piloto Internacional } \\
\text { para Conservação das Florestas Tropicais brasileiras (PPG-7) }\end{array}$ \\
\hline $6^{a}$ & $\begin{array}{l}\text { Segunda metade } \\
\text { da década de } 1990\end{array}$ & $\begin{array}{l}\text { Com base nos Eixos Nacionais de Integração e Desenvolvimento } \\
\text { (ENIDs) incorporados pelos Programas Brasil em Ação e Avança Brasil. }\end{array}$ \\
\hline
\end{tabular}

Fonte: Kholhepp, 2002. Organizado pelos autores. 


\section{Geografias de Rondônia Território, Fronteira e Educação}

Por sua vez, Mello e Théry (2001) contribuem com a periodização das transformações amazônicas propondo três fases, quais sejam: 1) na década de 1970 a ênfase esteve na infraestrutura do principal modal de transporte brasileiro, o rodoviário, bem como em projetos de colonização; 2) na década de 1980, por sua vez, o ordenamento territorial foi estruturado com base nos Polos de Crescimento, a exemplo do Polamazônia e Polonoroeste; 3) e finalmente, na segunda metade da década de 1990, as políticas territoriais promoveram os corredores de exportação, que foram responsáveis por reconfigurações espaciais/territoriais. Os autores descrevem as políticas territoriais ligadas aos corredores de exportação como "políticas contraditórias", haja vista apresentarem visões diferentes de desenvolvimento econômico e social para a Amazônia. No final da década de 1990 e início dos anos 2000 buscou-se promover um desenvolvimento pautado em políticas ambientais que, em parte, se configuraram pelo viés ricardiano ${ }^{2}$ de valoração dos recursos naturais e, ao mesmo tempo, perpetuando formas arcaicas de acumulação do capital. Acúmulo esse que foi marcado pela expansão da fronteira agrícola e expulsão dos povos indígenas e comunidades tradicionais dos territórios culturais.

As fases descritas do ordenamento territorial da Amazônia traduzem-se em impactos ambientais que amplificam os dados de desmatamento, queimadas, rápida degradação do solo e danos irreparáveis aos territórios tradicionais dos povos indígenas, comunidades quilombolas, ribeirinhos e seringueiros. Na medida em que o processo de expansão da fronteira se reveste de um sentido de "desbravamento" e "pioneirismo", onde os sujeitos se sentem heróis por abrirem estradas e criarem vilas e cidades, há toda uma engrenagem que molda a configuração socioterritorial da Amazônia.

Evidencia-se que todos os grandes projetos de infraestrutura na Amazônia trouxeram como lógica de ordenamento do território a sociabilidade do capital, sempre com apoio do Estado, no sentido de desconstituir os elementos amalgamadores dos povos amazônicos, ou seja, a expropriação dos territórios e da natureza. Na escala local, no mundo vivido das populações urbanas e rurais, partindo sempre as decisões de

\footnotetext{
2 Teoria de renda da terra e renda de escassez conceituadas por David Ricardo em seu livro Princípios da economia política e tributação escrito em 1817. Em suma, onde a demanda for maior que a oferta do recurso haverá cobrança de um preço público; é uma renda de escassez apropriada pelo dono, neste caso o Estado (Reis; Santin, 2007).
} 


\section{Fronteira, Direitos Humanos e Territórios Tradicionais em Rondônia [Amazônia brasileira]}

cima para baixo, os grandes projetos cristalizam nos lugares a solidariedade organizacional das empresas (Santos; Silveira, 2001), promovendo um processo de descaracterização da região, uma (des)amazonização da Amazônia.

Em resumo, esses são alguns dos processos que destacamos para compreender a forma como o ordenamento territorial da região amazônica se configurou e continua a se configurar, ao passo que promovem descaracterização social, cultural e ambiental, com forte intuito de pressionar os povos originários e comunidades tradicionais da Amazônia (Figura n. 1).

Atualmente, os instrumentos jurídicos de ordenamento territorial dos territórios protegidos (Unidades de Conservação, Terras Indígenas e Áreas Quilombolas) estão sendo erodidos pelo Estado neoliberal, de modo a prevalecer a forma corporativa-econômica que promove a agenda de enfraquecimento desses territórios, o que termina por fragilizá-los para atender os mecanismos de expansão da economia de fronteira e do mercado global de commodities. No caso de Rondônia, objeto de análise deste texto, compõem esse processo a pecuária, soja, madeira, mineração e o mercado de terras, sendo, pois, laboratório de políticas públicas aplicadas pelo Estado, com profundas mudanças, o que podemos designar como mundo agrário.

\section{RONDÔNIA: A MARCHA DA PECUÁRIA, MADEIRA, TERRA E SOJA}

Historicamente no Brasil, a pecuária é representada como uma das principais atividades responsáveis pela ocupação do território brasileiro, vista como um modelo de produção das áreas de expansão da fronteira agrícola, ancorada na intensa apropriação de terras e demais recursos naturais (Furtado, 2005; Barcellos et al., 2008; Becker, 2004). Segundo Barcellos et al. (2008, p. 52), a pecuária extensiva, na década de 1970, era compreendida como uma atividade que garantia segurança "em função de sua liquidez e baixo risco". Dessa maneira, a pecuária representava uma reserva de capital, uma vez que a dupla (boi e terra) correspondia à função de preservar ativos fixos, ou imobilizados, de reserva de valor, garantindo, dessa maneira, uma maior estabilidade econômica ao produtor.

Esse perfil da pecuária ainda repercute no aumento da área de pastagem, o que significa a incorporação de áreas de florestas pelas patas do boi. Com isso, promove-se tanto o deslocamento da fronteira quanto 


\section{Geografias de Rondônia Território, Fronteira e Educação}

o aumento das pressões político-territoriais nas Áreas Protegidas. Sabe-se que a pecuária extensiva na Amazônia está relacionada à baixa aplicabilidade de insumos tecnológicos, limitando a produtividade das pastagens e do rebanho. Isto significa que o manejo inadequado (solo, planta e animal) gera maior desgaste ambiental, indicando ser um dos fatores do deslocamento dessa atividade na fronteira. Decerto, a forma difundida pela exploração espacial da pecuária se correlaciona à baixa eficiência e menor produtividade (Ferreira et al., 2010).

No estado de Rondônia, a conversão de floresta em pastagens associa-se às dinâmicas espaciais dos grãos (soja e milho), que promovem a valorização da terra tanto para agricultura quanto para a pecuária (Costa Silva; Conceição, 2017). Em outras palavras, a expansão da fronteira agrícola se associa com o deslocamento da pecuária extensiva e, consequentemente, com o aumento nos conflitos socioterritoriais nos limites das Áreas Protegidas, ampliando a pressão econômica nos territórios tradicionais dos povos amazônicos. A fronteira realiza-se conjuntamente com o processo de especulação de terras, em que grandes grupos compram terras que servirão como reserva de valor (Ianni, 1979).

Figura 2 - Evolução do rebanho bovino em Rondônia (1990 a 2018).

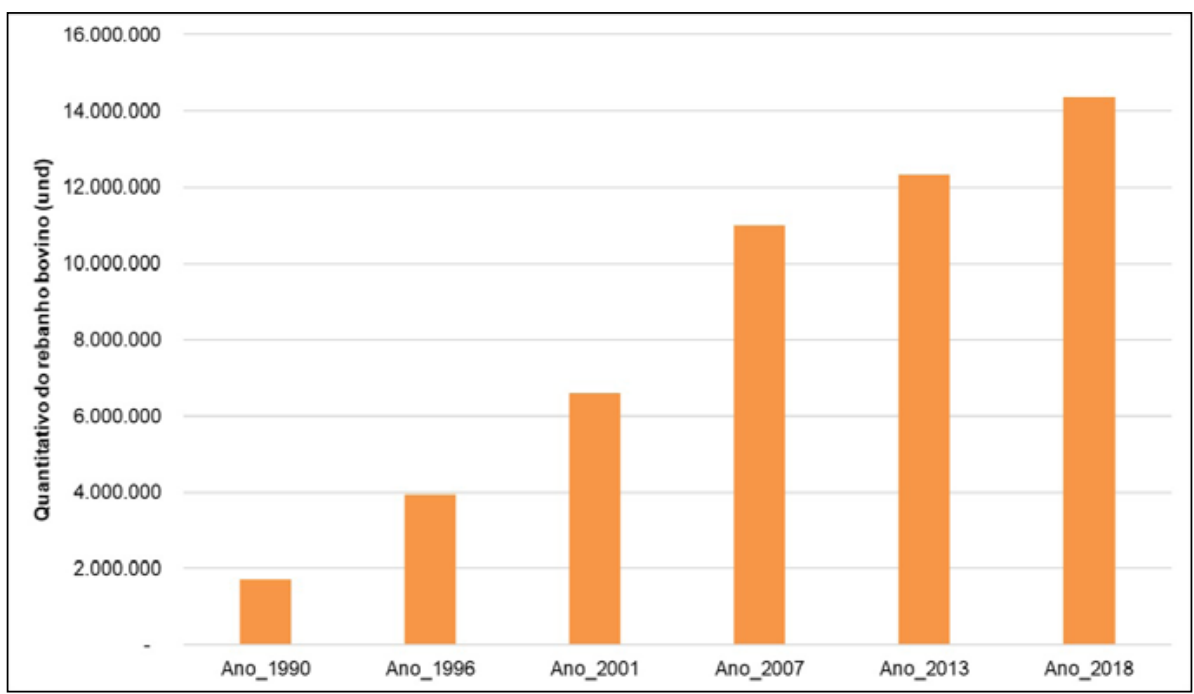

Fonte: PPM/IBGE/Sidra, 2019. Elaborado pelos autores. 


\section{Fronteira, Direitos Humanos e Territórios Tradicionais em Rondônia [Amazônia brasileira]}

Como objeto de análise, o estado de Rondônia é marcado por uma forte presença do capital agropecuário. De acordo com o Instituto Brasileiro de Geografia e Estatística - IBGE o setor agropecuário representa $13,89 \%{ }^{3}$ do Produto Interno Bruto (PIB), ocupando a terceira posição na composição do PIB estadual (IBGE, 2016). Apesar da sua colocação no ranking da economia estadual, este setor aparece como o principal indutor das transformações no espaço regional, desde a expansão da fronteira à migração campo-campo e campo-cidade (Costa Silva et al., 2017). A pecuária se destaca como umas das principais atividades que envolve todos os estratos fundiários, sendo pecuária (carne) e soja (farelo e grãos) os principais produtos de exportação. A pecuária extensiva em Rondônia alcança 62,17\% (IBGE, 2017) do número de estabelecimentos agropecuários. No Gráfico 1 podemos observar, nos últimos 20 anos, o crescimento do efetivo bovino de Rondônia.

O efetivo bovino rondoniense, entre os anos de 1998 e 2018, apresentou $736 \%$ de crescimento. Ao longo desses anos, Rondônia passou de 1.718.697 cabeças para mais de 14 milhões de bovinos, conforme podemos observar no cartograma que indica a distribuição espacial da pecuária em todos os municípios (Figura n. 3). Este aumento significativo possibilitou que o Estado atingisse a sexta $\left(6^{\mathrm{a}}\right)$ posição no ranking nacional e segunda $\left(2^{\mathrm{a}}\right)$ posição na Região Norte (IBGE, 2017). Em relação à área de pastagem, com base nos Censos Agropecuários (2006 e 2017), houve um acréscimo de $25 \%$ da área, passando de 4.565 .835 hectares (2006) para 5.740.063 hectares de pastagens plantadas (2017), o que lhe permitiu a nona $\left(9^{a}\right)$ colocação nacional e a terceira $\left(3^{a}\right)$ posição na Região Norte (IBGE, 2017).

${ }^{3}$ Referente ao ano de 2016. Segundo a tabela 5938 - Sidra/IBGE. 


\section{Geografias de Rondônia Território, Fronteira e Educação}

Figura 3 - Distribuição espacial da pecuária em Rondônia (1990 e 2018).

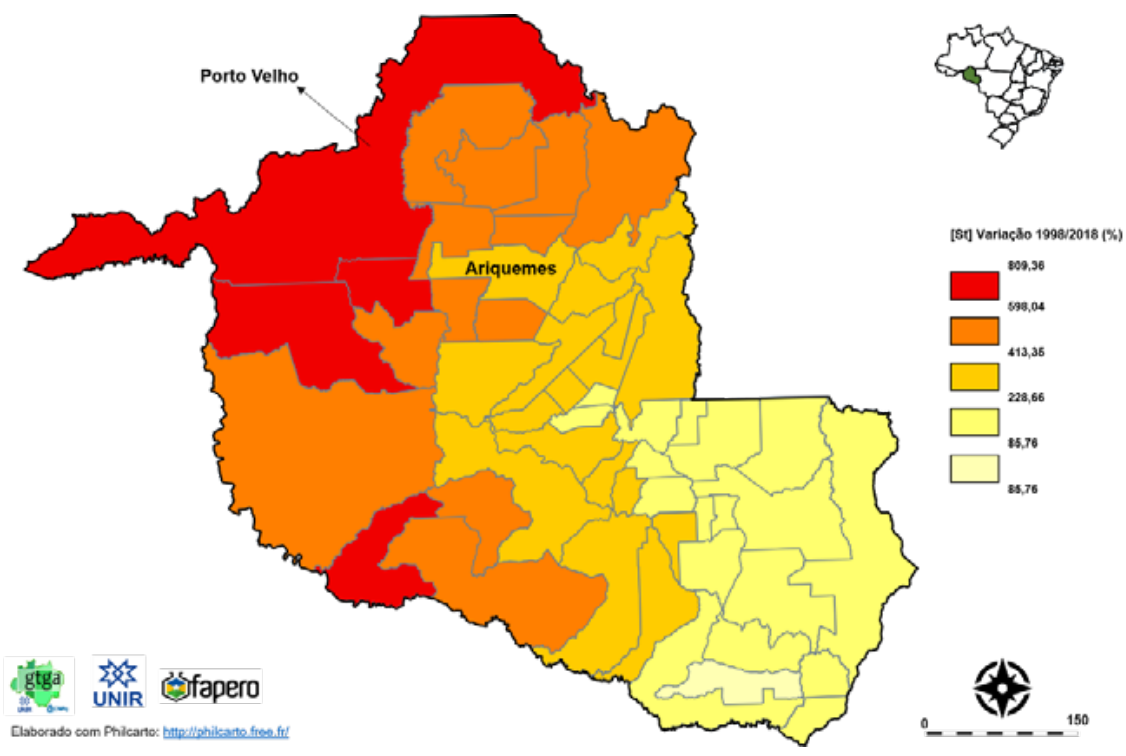

Fonte: IBGE, 2020. Organização: Autores.

Em Rondônia, dos 10 municípios que incorporaram áreas de pastagens, oito estão localizados no norte do estado, com destaque para Cujubim, que apresentou crescimento, no período entre 2006 e 2017 , de 155,91\% em área da pecuária. Este município findou o ano de 2018 com 49,80\% de aumento do desmatamento, assumindo a primeira posição dos municípios que mais desmataram nos últimos 18 anos. $\mathrm{O}$ número de propriedades com pecuária apresentou acréscimo de 19,05\% entre os anos de 2006 e 2017. Salienta-se que a pecuária expressa uma dinâmica territorial pautada na pressão de Áreas Protegidas, sobretudo, quando há um deslocamento espacial do sul para o norte rondoniense, contribuindo, até o ano de 2018, com 38,83\% de desmatamento em Rondônia. Entretanto, cabe acrescentar que essa dinâmica territorial, contraditoriamente, possibilita aos camponeses encararem a fronteira como uma maneira de reprodução social, territorial e econômica (Costa Silva, 2016; Wanderley, 2014). A pecuária que contribui com a reprodução social camponesa serve também como "manto" para encobrir latifundiários, haja vista que o quantitativo da área destinada à pastagem não expressa melhora na produtividade do rebanho de Rondônia. 
Dentre os grupos sociais e econômicos (camponeses, madeireiros, pecuaristas e grileiros) que movimentam a fronteira em Rondônia, iniciaremos com a análise da exploração madeireira. Como anteriormente exposto, a pecuária extensiva, por meio do manejo solo, planta e animal, não apresenta uma produtividade adequada. Além disso, continua exercendo a produção com rápida liquidez, necessitando de reserva de capital, neste caso, representada pela terra, sendo esta, ainda, o principal fator de produção da atividade, o que tende a refletir na permanente busca por novas áreas.

Como dinâmica territorial, essa conversão se dirige às Áreas Protegidas, principalmente nas Reservas Extrativistas e Terras Indígenas, como atualmente se verifica no norte de Rondônia, processo que decorre, sobretudo, do aumento do desmatamento ilegal praticado nessas áreas para fins tanto da exploração madeireira quanto às atividades agropecuárias e mercado de terras.

Esse processo contribui para o aumento dos conflitos socioterritoriais, visto que os recursos naturais em Áreas Protegidas passam a ser uma mercadoria essencial na expansão da fronteira. Diante disso, os territórios tradicionais dos seringueiros e indígenas, como veremos mais adiante, são "negligenciados" pelo Estado (Executivo, Legislativo e Judiciário), na medida em que essas áreas, sendo usurpadas pelos agentes da grilagem e do crime ambiental, violam os direitos humanos e territoriais dos povos amazônicos.

A exploração madeireira (legal e ilegal) assegura significativamente o deslocamento da fronteira em Rondônia. Assim como a pecuária, a madeira faz parte da tríade (pecuária, madeira e terra) que movimenta a fronteira, o que garantiu, em 2018, a terceira posição no comércio nacional, com $11 \%$ do volume total explorado no país. Os dois primeiros colocados são os estados de Mato Grosso, com 34\% e Pará, com $28 \%$ dos $11.616 .286 \mathrm{~m}^{3}$ de madeira em toras extraídas no Brasil. 


\section{Geografias de Rondônia Território, Fronteira e Educação}

Figura 4 - Produção de madeira por microrregiões de Rondônia $\left(\mathrm{m}^{3} 1990\right.$ e 2018).

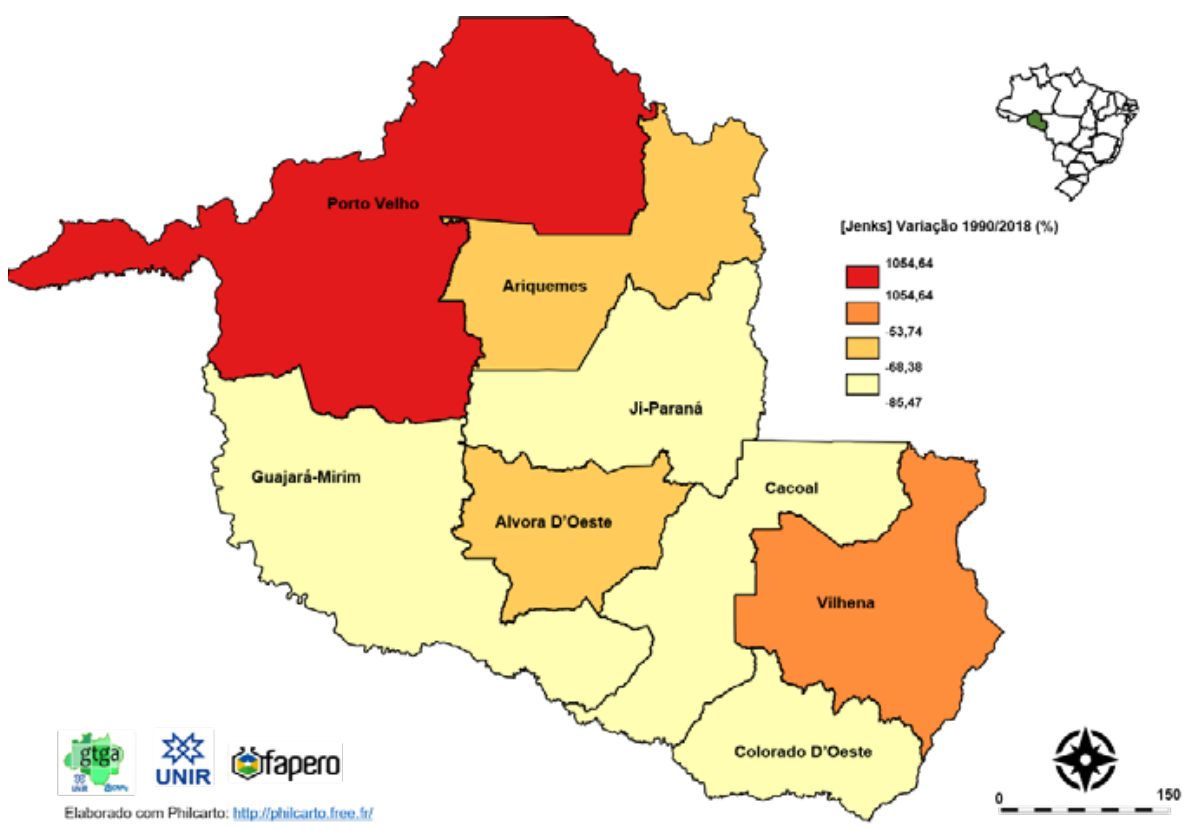

Fonte: IBGE, 2020. Organização: Autores.

Na Figura n. 4 estão indicadas as oito microrregiões de Rondônia, com dados referentes aos anos de 1990 e 2018, que respaldam o período com maior exploração madeireira no estado. No ano de 1990, as duas microrregiões com maior produção de exploração madeireira foram Ariquemes (35\%) e Cacoal (20\%), essas microrregiões são compostas por 16 municípios, 7 e 9 respectivamente. No ano de 2018, a microrregião de Porto Velho foi responsável por $60 \%$ da extração estadual. Nesta microrregião, os municípios com maiores volumes de exploração são: Porto Velho (45\%), Candeias do Jamari (29\%) e Cujubim (11\%). A microrregião de Ariquemes, no mesmo ano, foi responsável por $17 \%$ do volume explorado. Nesta microrregião, os municípios com maior representatividade na extração de madeira são: Machadinho D’Oeste (45\%), Rio Crespo (18\%) e Ariquemes (15\%). Ao correlacionarmos essas informações com os dados referentes ao desmatamento, identificamos que grande parte desses municípios que compõem essas duas microrregiões, com maior volume de extração de madeireira, estão entre os 10 municí- 


\section{Fronteira, Direitos Humanos e Territórios Tradicionais em Rondônia [Amazônia brasileira]}

pios com maior percentual de desmatamento e maior variação de incremento do desmatamento, em relação aos últimos 18 anos.

Com base nas informações coletadas na plataforma do Instituto Nacional de Pesquisas Espaciais (INPE), dos 52 municípios de Rondônia, 14 já possuem mais de $80 \%$ de sua extensão territorial desmatada ao longo dos últimos 50 anos (1970-2019). Também se destaca que três desses municípios encontram-se ao longo do eixo da BR-364, cuja formação territorial se deve aos núcleos dos projetos de colonização, sendo eles os municípios de Jaru, Presidente Médici e Ouro Preto do Oeste. Entretanto, os outros 11 municípios não estão ao longo da BR-364, mas em função do deslocamento da pecuária, no ano de 2018 incorporaram maiores áreas desflorestadas.

Segundo Michalski (2018), grande parte da madeira extraída no município de Porto Velho pode estar relacionada à extração ilegal. A autora apresenta essa hipótese com base em um estudo realizado pela Esalq/USP ${ }^{4}$, publicado no ano de 2018 , que aponta a fraude para legalizar a extração de árvores protegidas na Amazônia. Os dados analisados na referida pesquisa indicam a falsificação do selo $\mathrm{FSC}^{5}$, que libera licenças para madeiras extraídas, sendo essas, "legalizadas" no mercado. Portanto, nos $45 \%$ do volume de madeira em tora extraído no município de Porto Velho, podem estar incluídos os $29,45 \%$ do desmatamento da região. Além disso, o município registra a contínua ação criminosa de madeireiras que praticam crime ambiental (roubo de madeira) na Terra Indígena Karipuna, Resex Jacy-Paraná e Flona do Bom Futuro.

Esses grupos (madeireiros, fazendeiros, grileiros) buscam se apropriar dos recursos da natureza com a expansão da fronteira agrícola, o que implica no acréscimo de terras ao capital (Costa Silva, 2017). Dessa forma, por meio da expansão da fronteira, viabiliza-se a expropriação do campesinato nas demais sub-regiões rondonienses, favorecendo a incorporação de áreas ao agronegócio da soja. A expansão da fronteira promove o deslocamento da pecuária, acarretando tanto a marcha do desflorestamento quanto o surgimento dos conflitos socioterritoriais.

Adiciona-se ao processo o aquecimento do mercado de terras, sobretudo quando os produtores de soja almejam ampliar a área de produção, como atualmente ocorre nas microrregiões de Ariquemes e Porto

\footnotetext{
${ }^{4}$ Escola Superior de Agricultura Luiz de Queiroz da Universidade de São Paulo (USP).

${ }^{5}$ FSC Sistema de Certificação Florestal.
} 


\section{Geografias de Rondônia Território, Fronteira e Educação}

Velho. Desta maneira, promove-se a elevação do preço da terra, acarretando pressões econômicas e expropriações dos pequenos produtores/ campesinato. Portanto, a valorização das commodities agrícolas gera na Amazônia uma acentuada elevação no preço da terra, percebida como reserva de valor compatível aos agentes hegemônicos que, por sua vez, promovem um caráter especulativo e rentista do mercado (Costa Silva; Conceição, 2017).

No plano global, essa dinâmica é um reflexo da crise econômica ocorrida entre os anos de 2007 e 2010, o que obrigou o capital financeiro a investir em commodities agrícolas, minerais e compras de terras, uma verdadeira corrida em busca de recursos naturais. Dessa forma, amplia-se a especulação no mercado de terras, proporcionando assim, maior busca por reservas de valor que, consequentemente, indicam o aumento do latifúndio no Brasil, com impactos territoriais diretos na Amazônia.

$\mathrm{Na}$ escala regional, a expansão da fronteira agrícola, em Rondônia, busca formas de ramificação por meio da incorporação de áreas, ou seja, florestas transformadas em pastagens, com degradação ambiental (desmatamento e queimadas), assim como, amplia os conflitos socioterritoriais que objetivam erodir os direitos territoriais dos povos indígenas e comunidades tradicionais (seringueiros, ribeirinhos e quilombolas).

\section{A FRONTEIRA ATINGE OS TERRITÓRIOS TRADICIONAIS EM RONDÔNIA}

Nas últimas décadas, o norte/noroeste de Rondônia vem sendo transformado pelas frentes de expansão da pecuária e exploração ilegal de madeira, as quais estamos qualificando de expansão da fronteira. Diante disso, a fronteira se desloca para as Áreas Protegidas, a exemplo da Terra Indígena Karipuna, Reserva Extrativista Jacy-Paraná e Floresta Nacional Bom Futuro, processo que ocorre à medida que o desmatamento avança junto aos limites dessas áreas, levando à perda de serviços ambientais e até mesmo à redução ou redefinição de limites da área protegida (Imazon, 2018; Costa Silva, 2016).

Esse processo também atinge os direitos territoriais e, por conseguinte, os direitos humanos dos povos amazônicos, especificamente dos povos indígenas e dos seringueiros em análise neste estudo. A fronteira chegou nessas áreas protegidas, primeiro com o roubo de madeira, depois com tentativas de grilagens de terras, seguido da pecuária, o que tem contribuído com o aumento do desmatamento das Áreas Protegidas 


\section{Fronteira, Direitos Humanos e Territórios Tradicionais em Rondônia [Amazônia brasileira]}

mencionadas anteriormente e comprometendo as condições culturais, econômicas, sociais e ambientais dos povos amazônicos afetados.

A exploração ilegal da madeira funciona como uma maneira de obtenção imediata do valor na metamorfose da natureza em mercadoria, pois, a ilegalidade desta atividade que se desvia dos caminhos formais - pagamento de impostos, manejo florestal e outros serviços ambientais - alimenta toda uma cadeia de transgressões que prejudica e impacta os territórios tradicionais (CIMI, 2019). Segundo os dados do Programa de Monitoramento do Desmatamento da Floresta Amazônica Brasileira por Satélite (Prodes), entre 1988 e 2017, uma área de 2.823 hectares (ha) dos 152 mil hectares da TI Karipuna já foram desmatados, sendo que, $40 \%$ deste total, o que corresponde a 1.139 ha, ocorreu entre 2015 e 2017, o que indica que, nos últimos anos, houve uma aceleração da pressão territorial para desorganizar e invadir a Terra Indígena (Figura n. 5).

Como hipótese, indica-se que a expansão da pecuária nesta região, e consequente "corrida" pela terra púbica, foi motivada pelo deslocamento do agronegócio da soja do sul para o norte de Rondônia, fazendo com que a pecuária e o deslocamento populacional fossem empurrados para novas áreas rurais. Nesse sentido, ampliam-se os conflitos socioterritoriais e se confirma a dominação do território pelo capital agropecuário, assim como suas influências nas ações políticas que tendem à redução, fragilização e ou extinção de áreas protegidas, sejam Unidades de Conservação, Terras Indígenas ou Territórios Quilombolas (Costa Silva et al., 2017).

Conforme o Figura 4, as Áreas Protegidas em questão são alvos de atos criminosos da agrobandidagem que atua em toda a Amazônia. As Áreas Protegidas estão localizadas entres dois distritos do município de Porto Velho - União Bandeirantes e Rio Pardo - cuja economia se desenvolve, principalmente, a partir da pecuária e extração ilegal de madeira. De acordo com o Zoneamento Socioeconômico e Ecológico de Rondônia - ZSEE-RO (Rondônia, 2010), União Bandeirantes está na subzona 2.1 (área de conservação dos recursos naturais passível de uso sob manejo sustentável) e Rio Pardo está na subzona 3.2 (áreas destinadas às Unidades de Conservação de Proteção Integral). 
Figura 5 - Norte de Rondônia: Distritos de União Bandeirantes e Rio Pardo. Áreas Protegidas TI Karipuna, Resex Jacy-Paraná e Flona

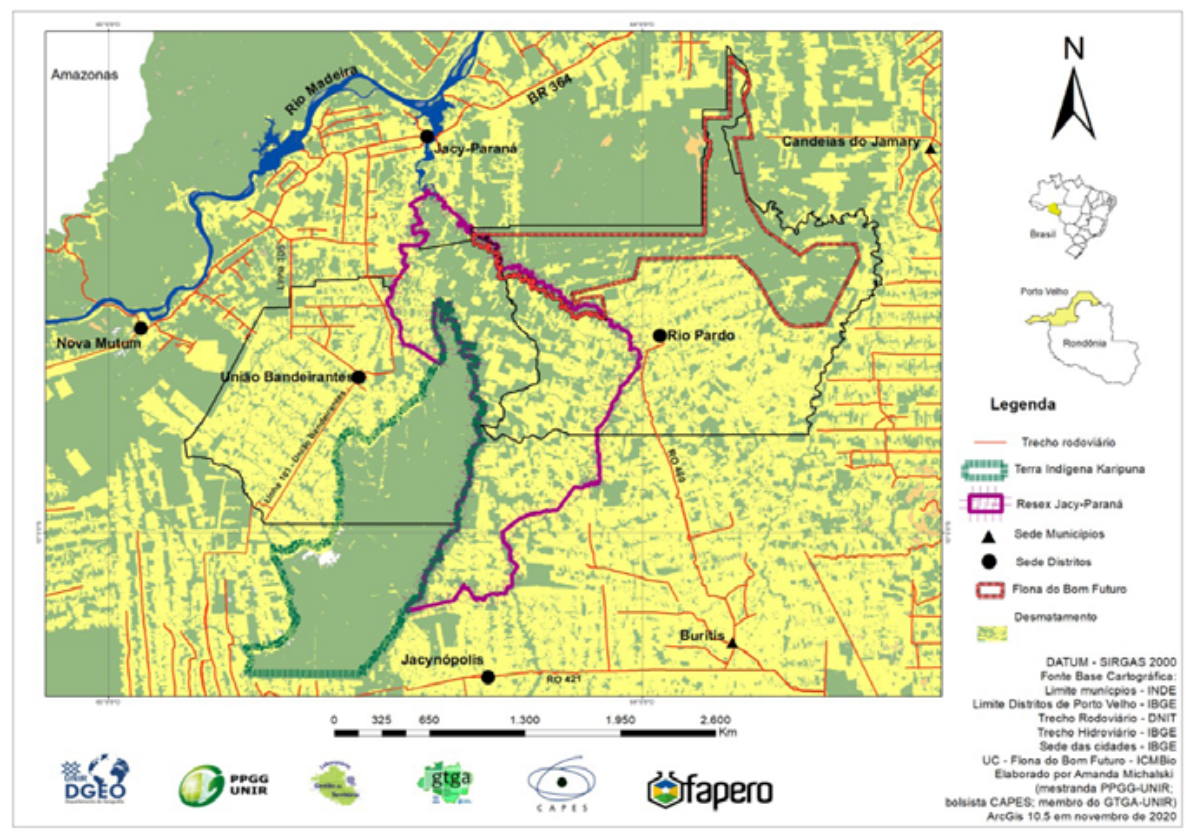

Fonte: Elaboração dos Autores.

A Reserva Extrativista Jacy-Paraná - território dos seringueiros vem sendo gradativamente destruída pela invasão de madeireiros, fazendeiros e pecuaristas, potencializando o desmatamento (Funai, 2018; Santana e Silva, 2019), situação de difícil controle ambiental que se encaminha à irreversibilidade. Essa destruição não causa somente impactos ambientais, mas impacta a vida de quem nela habita (os seringueiros), que com frequência são ameaçados de expulsão e de expropriação do território. Neste caso, trata-se de um processo contínuo de desterritorialização da comunidade tradicional. A Resex Jacy-Paraná tem uma área de 196.897,00ha, que até o ano de 2000 estava com pouca pressão antrópica, cujo desmatamento indicava apenas 778 hectares. O deslocamento da fronteira agrícola (pecuária, madeira e grilagem de terra) fez o desmatamento disparar, de modo que em 2016, a área desflorestada já correspondia a 77.536,31 hectares, e em 2017 apresentou 98.665 hecta- 


\section{Fronteira, Direitos Humanos e Territórios Tradicionais em Rondônia [Amazônia brasileira]}

res desmatados, o que equivale a quase $50 \%$ da Resex (Santana e Silva, 2019; ISA, 2019).

Os seringueiros da Resex praticam, prioritariamente, a coleta de frutos nativos (cupuaçu, tucumã, açaí, bacuri), coleta de castanha e a extração da borracha, assim como caça e pesca, e mesmo a reduzida atividade agrícola. Todas essas atividades podem servir tanto à obtenção de renda quanto à subsistência, instaurando as territorialidades desses grupos no interior do que ainda existe de floresta e do território tradicional que resiste à expansão da fronteira, sendo a Resex uma das mais invadidas e impactadas pela grilagem de terras em Rondônia.

A Terra Indígena Karipuna, assim como a Resex Jacy-Paraná, vêm sendo alvo de exploração ilegal de madeira em partes de sua área, cujo limite abre caminho para o alcance dos infratores que enxergam a floresta como fonte de acumulação (Funai 2018). Tais processos se relacionam a grupos organizados, verdadeiras agromilícias que agem por meio de invasões coordenadas para grilar a terra indígena, tentando fazer da TI Karipuna um laboratório da agrobandidagem na Amazônia, de modo a produzir um domínio político somado a uma situação social com vista a tornar irreversível a grilagem de terras, como ocorreu e ocorre na Resex Jacy-Paraná e na Flona do Bom Futuro. Essa é a aposta e o projeto territorial da agrobandidagem que age em Rondônia e na Amazônia brasileira. Umas da estratégia da agrobandidagem é incentivar a expansão da fronteira por meio do deslocamento do campesinato (posseiros), induzindo esses grupos a desbravarem áreas ambientais regulamentadas, com a intenção de pressionar o governo a alterar os limites de Unidades de Conservação e os tipos de usos descritos nos instrumentos de gestão territorial.

As ameaças à área indígena são diversas e envolvem desde a pressão menor de caçadores e pescadores, quanto a ação estratégica de madeireiros, grileiros e, em escala nacional, das solicitações de empresas mineradoras para pesquisa com vistas a extração de ouro e estanho (todos em estágio de requerimento de pesquisa no Departamento Nacional de Produção Mineral - DNPM (Costa Silva e Lima, 2020). Contudo, o roubo de madeira organizado pela indústria madeireira tem sido o ato mais criminoso e de maior ataque ao território dos Karipuna. Esse processo aumentou nos últimos anos, sobretudo em função conjuntura política do Brasil, em que os ataques aos territórios tradicionais e às Áreas Protegidas, de modo geral, produziram uma onda articulada de pressões políticas para fragilizar esses territórios protegidos. A TI Karipuna tem 153.000ha, com uma população aproximada de 55 indí- 


\section{Geografias de Rondônia Território, Fronteira e Educação}

genas, cuja evolução demográfica tem sido positiva desde 2004. Até o ano de 2000 havia somente 305 ha desmatados, aumentando tal pressão desde 2014 e chegando a 1.426 hectares desmatados em 2017 (ISA, 2019). Recentemente, no ano de 2018 e 2019, a agrobandidagem leiloou lotes na área indígena Karipuna com organização social e serviço de topografia e geoprocessamento, o que acendeu o alerta nas instituições públicas no sentido de produzir uma resposta rápida e eficaz.

Toda essa pressão econômica e territorial levou os órgãos públicos de fiscalização, controle e judicial, somada às denúncias feitas pelas organizações indígenas e organizações sociais de apoio aos povos indígenas, a manifestarem preocupações quanto aos atos de violências, de invasões e de possível genocídio na TI Karipuna. Desde 2016, as organizações sociais de apoio aos povos indígenas, inúmeras vezes, denunciaram junto ao Ministério Público Federal, Polícia Federal e Funai os incessantes mecanismos de invasões na TI Karipuna. Em 2018 e 2019, as instituições públicas formaram uma força tarefa para investigar e combater o crime organizado, a agrobandidagem e a agromilícia que atuavam na área indígena:

A Força-tarefa Amazônia, do Ministério Público Federal (MPF), articulou, nos últimos seis meses, quatro grandes operações para proteção de terras indígenas e unidades de conservação em Rondônia. Duas das operações são referentes à terra indígena Karipuna, uma foi na Floresta Nacional do Bom Futuro e a outra refere-se à terra indígena Uru-Eu-Wau-Wau. Ao todo foram 30 pessoas e oito empresas denunciadas por crimes como invasão de terras indígenas, lavagem de dinheiro, organização criminosa, dano ambiental, entre outros. Na Operação Floresta Virtual o foco foi a exploração predatória de madeiras na terra indígena Karipuna e os métodos de lavagem empregados pelas serrarias de União Bandeirantes, localidade que é um distrito de Porto Velho. Descobriu-se durante as investigações que os responsáveis pelas madeireiras desenvolveram um grande esquema de falsificação de documentos de origem florestal (DOFs), com inserção de informações falsas no Sistema DOF, sistema informatizado administrado pelo Ibama (MPF, 16/10/2019). 


\section{Fronteira, Direitos Humanos e Territórios Tradicionais em Rondônia [Amazônia brasileira]}

A agrobandidagem tem atuado em várias sub-regiões rondonienses com o propósito de invadir Unidades de Conservação e Terras indígenas e criar situações de apelo social e pressão para que o Estado aceite a conversão de áreas florestais em espaço da agropecuária, da extração madeireira, da mineração e do mercado de terras.

A narrativa de que os pequenos produtores/campesinato precisam de terras para trabalho se tornou comum nesse processo. Todavia, a estratégia frequentemente é de usá-los para garantir no médio prazo um mercado de terras à agropecuária e ao agronegócio, assim como, justificar a abertura das áreas indígenas à exploração mineral e florestal. Dessa forma, a agrobandidagem, em conjunto com organizações de garimpeiros, inventam o problema mineral em Rondônia.

Outra unidade de conservação que sofreu com esse processo foi a Floresta Nacional do Bom Futuro, que começou a ser ocupada desordenadamente a partir de 1995 e 1997, com a instalação de dois assentamentos do Incra. Seguiram-se várias ocupações irregulares na região, inclusive simuladas por agentes políticos locais que ali montaram currais eleitorais. Dessa forma, esses processos, em 2010, reduziram em mais de $65 \%$ a área da Flona do Bom Futuro. A área original desta Unidade de Conservação era de 280.000ha, e por meio da Lei 12.249 de 14 de junho de 2010, teve seus limites reduzidos para 97.357ha. Com a nova delimitação, a degradação ambiental não cessou e, atualmente, expressa um resultado devastador: cerca de $15,13 \%$ da área da Flona, que correspondem a 14.783ha já foram desmatados, registrando a ocupação de 3,5 mil habitantes e 35 mil bovinos ilegais (MMA, 2009; ISA, 2019).

\section{Direitos Humanos E Território: APONTAMENTOS PARA PESQUISA}

A questão da fronteira na Amazônia (agrícola, mineral, madeireira, hidroenergético, mercado de terras global) que se direciona às áreas mais distantes e inacessíveis, assusta os povos amazônicos que vivem em seus territórios tradicionais ou culturais.

Esse deslocamento, às vezes pontual, outras vezes em ritmos acelerados, de certa forma, esgotou o que se debatia anteriormente como "terras devolutas", como terras de ninguém, onde a posse ou a invasão de terras públicas bastaria para impor uma territorialidade, um projeto de território. Em muitas áreas da Amazônia o capital, ou a sociedade do capital chegou primeiro que o Estado e suas normas. 


\section{Geografias de Rondônia Território, Fronteira e Educação}

Não devemos esquecer que o primeiro estudo amplo dos recursos naturais da Amazônia, assim como a sua potencialidade, foi realizado no período de 1970/1985, pelo Ministério das Minas e Energia, no âmbito do Projeto RadamBrasil. Nesse período, havia uma recente ocupação na Amazônia, desde a década de 1960, quando a abertura da rodovia Belém-Brasília e a colonização da transamazônica constituíram os elementos iniciais, do que foi qualificado pelas ciências sociais como fronteira e frentes pioneiras.

Nesse processo, os territórios e os povos amazônicos foram ignorados, silenciados, sendo as primeiras vítimas da chamada modernização da Amazônia. Nas décadas de 1980/1990/2000 os ventos do reconhecimento do Estado brasileiro para com esses povos amazônicos se converteram em inúmeras políticas públicas, dentre as quais, certamente, o reconhecimento legal de seus territórios foram as mais importantes, porque entendia e normatizava uma ordem jurídica que garantia aos grupos sociais um território coletivo em suas múltiplas territorialidades.

Passadas décadas, muitas lutas e resistências dos povos indígenas, ribeirinhos, quilombolas, seringueiros, quebradeiras de coco, pescadores, extrativistas, camponeses ribeirinhos, camponeses agroextrativistas e tantos outros grupos sociais que podemos designar como povos amazônicos, seus territórios se encontram ameaçados pelas forças econômicas que querem transformar a natureza, a exuberante floresta, os caudalosos rios, em paisagem do fogo, do pasto, dos grãos e das represas, em paisagem da anti-natureza, em paisagem do anti-povo-amazônico.

O debate central, sob nosso entendimento, indica que a questão agrária se reveste de questão territorial, na medida em que a luta é para assegurar os direitos territoriais consolidados pelo Estado brasileiro em Áreas Protegidas, espaço e territórios dos povos amazônicos. A agenda política do agronegócio é rever e destruir esses direitos duramente conquistados pelos povos e comunidades tradicionais amazônicas (Costa Silva e Lima, 2020).

As ondas de violências aos povos amazônicos, as pressões econômicas e crimes ambientais contra seus territórios ensejam pesquisas referentes ao reconhecimento das diferenças culturais, dos direitos humanos e da defesa da natureza como processo indissociável à vida coletiva e à reprodução social desses grupos.

Tais processos convergem à indissociabilidade temática dos direitos humanos e direitos territoriais, ao território como condição de vida coletiva. Nesse sentido, o campo de luta, sofrimento e resistências dos 


\section{Fronteira, Direitos Humanos e Territórios Tradicionais em Rondônia [Amazônia brasileira]}

indígenas e dos seringueiros, como analisado em Rondônia, impõem-se como agenda de pesquisa com vistas a contribuir para o entendimento geral das questões postas, assim como, para a construção de instrumentos de lutas para com os povos amazônicos em suas pautas e desafios sociais e territoriais.

\section{CONSIDERAÇÕES FINAIS}

Todos esses processos de grilagem colocam em risco os direitos territoriais de povos indígenas, quilombolas, ribeirinhos, seringueiros, pescadores e outras comunidades tradicionais que dependem da natureza para viver. À medida em que o desmatamento se alastra, a possibilidade de vida nessas áreas tende a diminuir, sobretudo, quando associada à grilagem, há todo tipo de crime e ameaças aos povos amazônicos em seus territórios.

As três Áreas Protegida mencionadas neste estudo (TI Karipuna, Resex Jacy-Paraná e Flona do Bom Futuro) estão localizadas no norte de Rondônia, região de expansão da fronteira impulsionada pela extração ilegal de madeira, grilagem de terras e pecuária. Elas cristalizam as ameaças aos territórios protegidos na Amazônia, às disputas por territórios no sentido de se projetar um espaço do agronegócio da soja, considerando que a "demanda” por terra empurra a pecuária e a exploração madeireira para novas frentes, cujo limite parece indicar justamente as Áreas Protegidas. Neste caso, os povos indígenas, as comunidades tradicionais e os setores do campesinato sofrem esse processo de expropriação, violência e crime ambiental em seus territórios.

Os processos moleculares de acumulação do capital que fazem expandir a fronteira atingem os territórios dos povos e comunidades tradicionais amazônicas, constituindo em campo de conflitos sociais que adquire escala global. $\mathrm{Na}$ medida em que o capital global e seus aliados nas elites locais promovem a pilhagem de áreas públicas destinadas pelo Estado aos povos amazônicos, o capital tende a não respeitar e a ignorar as bases jurídicas e os ordenamentos territoriais que visam proteger tanto a natureza e seus serviços ambientais, quanto a reprodução social das coletividades que têm nos territórios a condição política de sua existência.

De modo global, as dinâmicas territoriais que aceleram as transformações no mundo agrário amazônico, cujos impactos mais severos atingem os territórios dos povos indígenas e comunidades tradicionais, 


\section{Geografias de Rondônia Território, Fronteira e Educação}

impõem pensar a relação teórica da geografia com os direitos básicos desses grupos sociais, a articulação do território com direitos humanos e territoriais, condição necessária para se constituir a pesquisa com compromisso social e significados humanos.

\section{REFERÊNCIAS}

BARCELOS, A. O.; RAMOS, A.K.B.; VILELA, L.; MARTHA JUNIOR, G.B. Sustentabilidade da produção animal baseada em pastagens consorciadas e no emprego de leguminosas exclusivas, na forma de banco de proteínas, nos trópicos brasileiros. Revista Brasileira de Zootecnia, 2008, v. 37, p. 51-67

BECKER, B. Amazônia: geopolítica na virada do III milênio. Rio de Janeiro: Garamond, 2004.

CIMI. Conselho Indigenista Missionário. Grileiros intensificam invasão na Terra Indígena Karipuna, em Rondônia. Reportagem do Greenpeace Brasil publicada em 24/01/2019. Disponível em https://cimi.org. br/2019/01/grileiros-intensificam-invasao-na-terra-indigena-karipuna-em-RONDÔNIA/ Acesso em: 20 de março 2020.

COSTA SILVA, R. G. Agentes, procesos y conflictos en la gestión territorial en el estado de Rondônia (Brasil). Polis, 2016, v. 15, n. 45, p. 319-344

COSTA SILVA, R. G. Da apropriação da Terra ao domínio do território: as estratégias do agronegócio na Amazônia brasileira. International Journal of Development Research, 2017, v. 7, n. 12, p. 17699-17707, 2017.

COSTA SILVA, R. G.; MICHALSKI, A; LIMA, L. A. P.; CONCEIÇÃO, F. S. Geografia das dinâmicas territoriais agrárias de Rondônia. In: Ferreira, G.H.C. (Org.). Geografia agrária em debate: das lutas históricas às práticas agroecológicas. Jundiaí: Paco Editorial, 2017, p. 143-162. COSTA SILVA, R.G.; CONCEIÇÃO, F. S. Agronegócio e campesinato na Amazônia brasileira: transformações geográficas em duas regiões nos estados de Rondônia e Pará. Geographia (UFF), 2017, v. 19, p. 54-72.

COSTA SILVA, R.G; LIMA, L.A.P; CONCEIÇÃO, F. S. (Orgs.). Amazônia: dinâmicas agrárias e territoriais contemporâneas. São Carlos: Editora Pedro \& João, 2018.

COY, M; KLINGLER, M; KOHLHEPP, G. De frontier até pós-frontier: regiões pioneiras no Brasil dentro do processo de transformação espaço- 
-temporal e sócio-ecológico. Confins, 2017, v. 30, n. 30. Disponível em https://journals.openedition.org/confins/11683. Acesso em: 23 de outubro de 2019.

FERREIRA, R.R.M; TAVARES FILHO, J.; FERREIRA, V.M. Efeitos de sistemas de manejo de pastagens nas propriedades físicas do solo. Semina: Ciências Agrárias, 2010, v. 31, n. 4, p. 913-932.

Funai. Fundação Nacional do Índio. Disponível em: www.funai.gov.br/ index.php/comunicacao/noticias/5502-operacao-sos-karipuna-investiga-organizacoes-criminosas-que-atuavam-em-terra-indigena-em-RONDÔNIA. Acesso em: 23 out. 2019.

FURTADO, C. Formação econômica do Brasil. São Paulo: Companhia Editora Nacional, 2005.

IANNI, O. Colonização e contra-reforma agrária na Amazônia. Petrópolis: Vozes, 1979.

IBGE - Instituto Brasileiro de Geografia e Estatística. Pesquisa do Censo Agropecuário 2006 e 2017 - Pecuária Municipal. Brasil, 2017

IBGE - Instituto Brasileiro de Geografia e Estatística. Produto Interno Bruto - 2016. Brasil, 2016.

IMAZON. Instituto do Homem e Meio Ambiente da Amazônia. Disponível em https://imazon.org.br/?s=\%C3\%A1reas+protegidas\&submit-search=. Acesso em: 24 out. 2020.

ISA. Instituto Socioambiental. Plataforma Terras Indígenas do Brasil. Terra Indígena Karipuna. 2019. Disponível em https://terrasindigenas. org.br/pt-br/terras-indigenas/3723\#demografia. Acesso em: 24 out. 2020.

ISA. Instituto Socioambiental. Unidades de Conservação do Brasil. Floresta Nacional do Bom Futuro. ISA, 2019. Disponível em https://uc. socioambiental.org/arp/639. Acesso em: 31 out. 2020.

KOHLHEPP, G. Conflitos de interesse no ordenamento territorial da Amazônia brasileira. Estudos Avançados, 2002, v. 16, n. 45, p. 37-61.

MELLO, N.A.; THÉRY, H. A armadura do espaço amazônico: eixos e zoneamento. Alceu, 2001, v. 1, n. 2, p. 181-214.

MICHALSKI, A. Geografia da pecuária e do desmatamento em Porto Velho: União Bandeirantes e Rio Pardo. Monografia (Graduação em Geografia) - Fundação Universidade Federal de Rondônia. Porto Velho, Rondônia, 2018. 


\section{Geografias de Rondônia Território, Fronteira e Educação}

MPF. Força-tarefa Amazônia fez quatro operações e denunciou 30 pessoas e oito madeireiras por crimes em Rondônia. MPF. Publicado em 16 de outubro de 2019. Disponível em www.mpf.mp.br/ro/salade-imprensa/noticias-ro/forca-tarefa-amazonia-fez-quatro-operacoes-edenunciou-30-pessoas-e-oito-madeireiras-por-crimes-em-RONDÔNIA. Acesso em: 31 out. 2020.

PRODES/INPE. Desflorestamento nas unidades de conservação. 2018. Disponível em www.dpi.inpe.br/prodesdigital/prodesuc.php Acesso em: 31 out. 2020.

PRODES/INPE. Desflorestamento nos municípios. 2018. Disponível em: www.dpi.inpe.br/prodesdigital/prodesmunicipal.php Acesso em: 19 ago. 2019.

RAFFESTIN, C. Por uma Geografia do Poder. São Paulo: Ática, 1993. REIS, A.; SANTIN, M.F.C.L. A teoria da renda da terra ricardiana: um marco unificador entre as economias da poluição e dos recursos naturais. Perspectiva Econômica, 2007, v. 3, n. 2, p. 65-81.

RONDÔNIA. Governo do Estado de Rondônia. Secretaria de Estado do Desenvolvimento Ambiental. 21 anos de Zoneamento Socioeconômico e ecológico do Estado de Rondônia: planejamento para o desenvolvimento sustentável e proteção ambiental. Sedam, Porto Velho, 2010.

SANTANA, R.S.; SILVA, S.C.P.G. Avaliação do avanço do desmatamento na Reserva Estadual Extrativista Jaci-Paraná-RO, no período de 1996 a 2016. Terr@Plural, 2019, v. 13, n. 1, p. 93-105.

TRINDADE JÚNIOR, S.C.; MADEIRA, W.V. Polos, eixos e zonas: cidades e ordenamento territorial na Amazônia. PRACS - Revista Eletrônica de Humanidades do Curso de Ciências Sociais da Unifap, 2016, v. 9, n. 1, p. 37-54.

WANDERLEY, M.N.B. O campesinato brasileiro: uma história de resistência. RESR, 2014, v. 52, n. 1, p. 25-44. 


\title{
A CAMINHO DO NORTE: CARTOGRAFIA DOS IMPACTOS TERRITORIAIS DO AGRONEGÓCIO EM RONDÔNIA (Amazônia OCIDENTAL) ${ }^{1}$
}

\author{
Ricardo Gilson da Costa Silva" \\ Amanda Michalski***
}

\section{INTRODUÇãO}

Iniciamos a análise com a seguinte indagação: a partir do agronegócio, quais desafios se impõem à Amazônia?

Para a questão posta, nossa abordagem será trilhada pela perspectiva miltoniana do espaço geográfico - o espaço híbrido (Santos, 1996). Nesse caminho encontramos significados de que o mundo em que vivemos, o mundo amazônico, composto por grupos sociais, comunidades, cidades e campos, permite-nos observar que a questão da materialidade e imaterialidade construída e apropriada, do lugar ao mundo, o espaço é nossa certeza existencial, experienciada em harmonias, dificuldades, conflitos e desafios.

O mundo se realiza nos lugares, nos territórios, nas regiões, mostrando-se como espaço produzido, composto por natureza, objetos técnicos e culturais (Santos, 1996), no qual os grupos sociais realizam a vida e vivenciam o mundo a partir do lugar. Podemos asseverar que a ordem que transforma o tempo social na Amazônia, que acelera o espaço (espaço-tempo-sociedade) tem elementos mais exógenos, con-

\footnotetext{
${ }^{1}$ A pesquisa contou com apoio das instituições: Fapero, Dhjus/Emeron e Capes. Publicado em: COSTA SILVA, R. G; MICHALSKI, A. A caminho do Norte: cartografia dos impactos territoriais do agronegócio em Rondônia (Amazônia ocidental). Confins, n. 45, p. 1-22, Paris, 2020.

https://orcid.org/0000-0002-3348-9629

"* https://orcid.org/0000-0003-0855-502X
} 


\section{Geografias de Rondônia Território, Fronteira e Educação}

temporaneamente materializada nos fluxos de commodities (carne, minério e soja). Trata-se de mercadorias que, para além de sua dimensão produtiva e econômica, assumem a condição de domínio territorial que tende a subverter os lugares atingidos, compondo-se como feixes de forças externas que cada vez mais se mostram como agenda territorial (no sentido de produzir espaço), conformando territórios a sua imagem.

Se imaginarmos a Amazônia como expressões territoriais de modos de vida e de relação dos grupos humanos com a natureza, podemos admitir, ao menos no espaço agrário, um mundo das águas (rios e lagos), das florestas e dos campos (agrícola e extrativista). Nesses mundos há todo um conjunto de particularidades socioculturais que evidenciam tanto a história quanto as aprendizagens pela memória e identidade dos grupos sociais que ensinam à sociedade urbana-industrial como viver e conviver com a natureza.

A diversidade sociocultural e os territórios tradicionais são expressões indissociáveis do nexo natureza, identidade, pertencimento, trabalho e trocas sociais. Assim, o território "é o chão e mais a população, isto é, uma identidade, o fato e o sentimento de pertencer àquilo que nos pertence. O território é a base do trabalho, da residência, das trocas materiais e espirituais e da vida, sobre os quais ele influi" (Santos, 2000, p. 96). Isso nos faz pensar a diversidade amazônica como modos de vida, completamente diferentes e contra-hegemônicos à linearidade econômica do agronegócio, que tende a converter e subjugar a diversidade socioambiental em monoculturas dos grãos, em unicidade mercantil.

Essas dialéticas se cristalizam no crescimento da área de soja na Amazônia, traduzindo-se em agenda territorial do agronegócio, cujas ameaças às áreas protegidas (Unidades de Conservação, Terras Indígenas e Terras Quilombolas) e, mesmo, à revisão jurídica desses ordenamentos territoriais, trazem a assunção de uma economia agrícola com pretensões imperativas - portanto, de domínio político, econômico e territorial - aos grupos sociais mais vulneráveis do mundo agrário amazônico.

Nesse sentido, a dimensão territorial da soja expressa a cartografia de um poder político-econômico-territorial, assentado nas oligarquias regionais com irrestrito apoio da mídia corporativa nacional/ regional, cujo discurso atribui às organizações sociais, povos, comunidades tradicionais, camponeses e agricultores familiares o estigma do atraso econômico, resultando, diretamente, em ataques aos territórios culturais e áreas protegidas, com consequente expansão das fronteiras agrícolas. O crescimento do agronegócio sojeiro implica diretamente na 


\section{A caminho do Norte: cartografia dos impactos territoriais do agronegócio em Rondônia [Amazônia Dcidental]}

expansão das fronteiras desse cultivo no Brasil, particularmente, acelerando as dinâmicas territoriais agrárias na Amazônia brasileira. Quais os caminhos dessa geografia?

Inicialmente, por fronteira, entende-se o espaço do conflito (Martins, 1997), das temporalidades, o limite entre a ótica do capital que tudo tende a transformar em mercadoria - e a vivência dos povos, comunidades tradicionais e camponeses amazônicos, que experienciam a sociobiodiversidade e os territórios como condição indissociável de sua história (Costa Silva, 2015; Costa Silva; Conceição, 2017; Costa Silva; Silva; Lima, 2019).

A fronteira é espaço-tempo, campo da vida e da violência, seus contornos nos mostram que, mesmo com a ação jurídica do Estado em preservar a natureza e os grupos sociais vulneráveis, protegendo-os por meio dos instrumentos modernos de gestão do território, instituindo espaços coletivos e territórios tradicionais, esses territórios estão ameaçados, pressionados e aliciados pelas frentes de expansão do capital agrário-financeiro, o que nos faz observar que as coerções territoriais do agronegócio para expandir o espaço da agropecuária se realiza na incorporação de áreas protegidas, áreas públicas, fazendo expandir a fronteira na Amazônia com violência e crime ambiental (Becker, 1995; Mello-Théry, 2011; Costa Silva; Conceição, 2017).

Ao utilizarmos a cartografia como metodologia de pesquisa (Archela e Théry, 2008), procuramos identificar os processos socioespaciais que assumem relevância nas escalas nacional e regional, podendo indicar períodos e lugares trilhados pela soja, o que certamente nos permite distinguir frentes de expansão do agronegócio e os limites territoriais desse processo.

Neste caso, partindo de uma leitura global, da totalidade histórica como ponto de ação do pensamento, na primeira seção analisamos os caminhos da soja no Brasil, que tende a se deslocar para o Norte, para a Amazônia profunda. Na seção seguinte, a escala regional se direciona para a configuração territorial da soja no estado de Rondônia, indicando seus efeitos espaciais na formação de novas fronteiras interestaduais. A escala local-regional está mais detalhadamente exposta na abordagem referente à região de União Bandeirantes, localizada no município de Porto Velho, onde esses processos de deslocamento da fronteira se fazem mais evidentes. Em seguida, encaminhamos as conclusões deste estudo. 


\section{Os CAMINHOS DA SOJA PARA O NORTE DO BRASIL}

A periodização se torna um bom recurso de método (Santos, 1996 e 2000) para representar os processos que transformam o Brasil, no caso específico, o crescimento e o mundo da soja nas regiões brasileiras. A cartografia, igualmente, ajuda-nos a pensar a relação sociedade-espaço, o mundo agrário e seus processos transformadores nas diversas escalas geográficas da relação social, portanto, o espaço em movimento (Théry, 2005; Martinelli, 2005; Archela e Théry, 2008).

A produção de soja tem levado o Brasil a patamares de competitividade global, mobilizando as estruturas públicas a servirem ao que podemos chamar de novo "messianismo econômico" no mundo agrário. Tudo parece se resumir à soja e suas contribuições à economia nacional. Uma das características desta commodity é o domínio territorial, a concentração da terra, coerção territorial e expulsão da população rural. 


\section{A caminho do Norte: cartografia dos impactos territoriais do agronegócio em Rondônia [Amazônia Dcidental]}

Mapa 1 - Cartografia da produção de soja no Brasil $(1980 / 1990 / 2000 / 2018)^{2}$
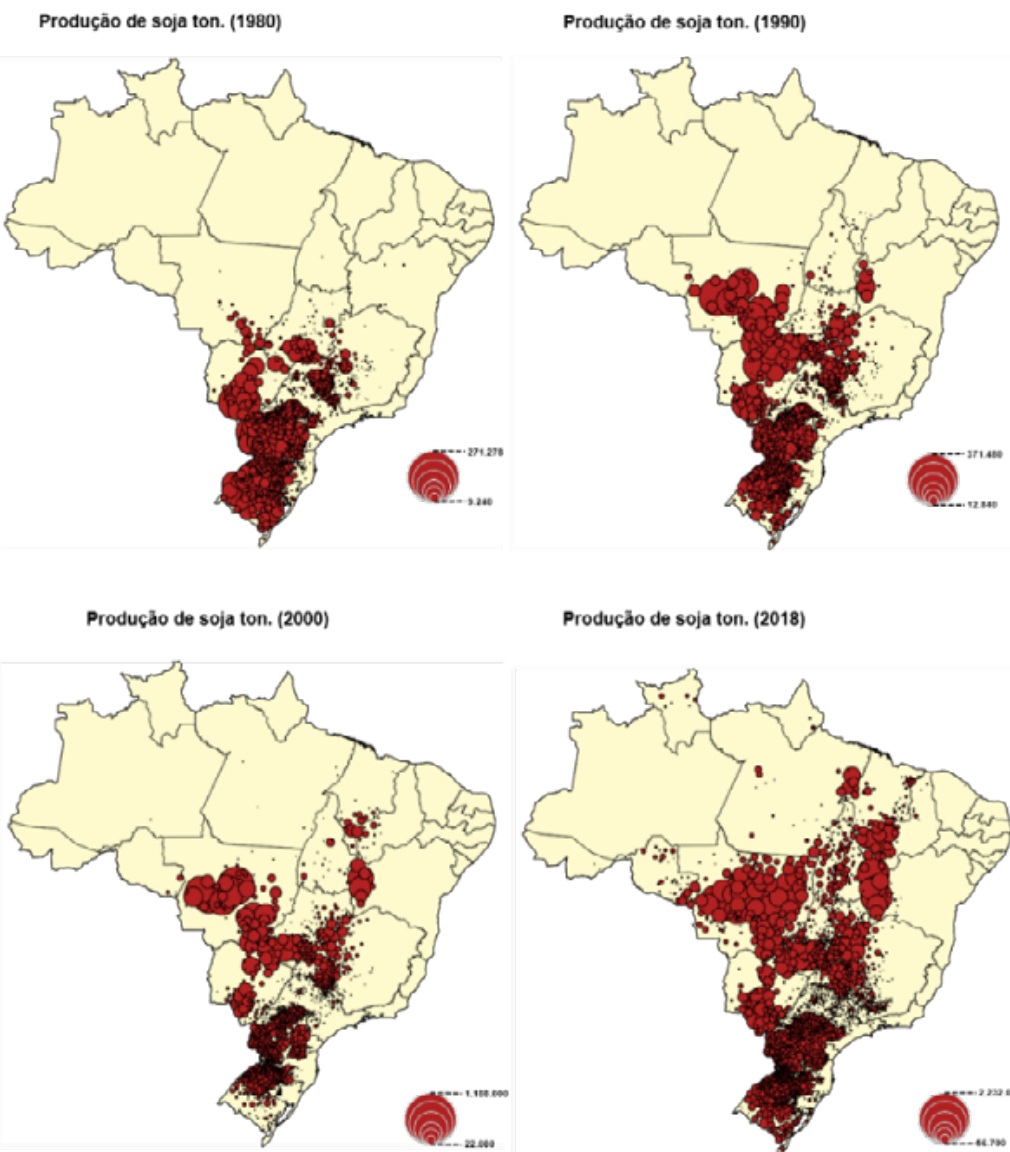

Produçăo de soja ton. (2018)

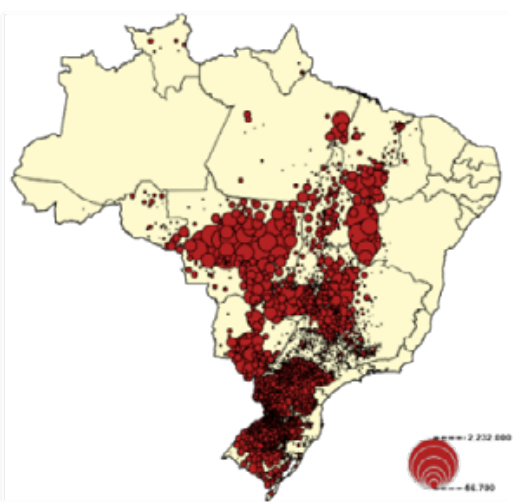

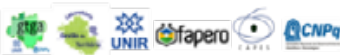

Fonte: IBGE - Produção Agrícola Municipal. Organização: Autores (RGCS/AM).

${ }^{2}$ Nota metodológica: para a elaboração dos mapas no Philcarto, optarmos por deixar na legenda a maior produção municipal por ano. Significa que o maior círculo proporcional se refere ao município que mais produziu soja no ano referente. Assim, por exemplo, em 1980, a maior produção municipal foi de Cascavel (PR), com 271.278 toneladas; em 1990 foi Campo Novo do Parecis (MT), com 371.480 toneladas; em 2000 foi Sorriso (MT), com 1.188.000 toneladas; e em 2018, novamente Sorriso (MT), com 2.232.000 toneladas. 


\section{Geografias de Rondônia Território, Fronteira e Educação}

Em termos de domínio territorial se verifica o deslocamento da soja para regiões brasileiras que na década de 1970 pouco apresentavam condições de absorver monocultivos, contudo, sendo áreas que já estavam territorializadas por populações e comunidades rurais. Assim, cartografamos a geografia da soja no Brasil (Mapa 1) admitindo três períodos: a Região Sul, como origem da soja (1980/1990); o Centro-Oeste, como fronteira agrícola global (a partir de 1990); e as novas fronteiras no Nordeste e Norte (a partir de 2000 e 2018).

Em uma primeira aproximação, até as décadas de 1980/1990, os caminhos da soja estavam circunscritos ao Centro-Sul do Brasil, especialmente no oeste dos estados do Rio Grande do Sul (RS) e Paraná (PR), sul do Mato Grosso do Sul (MS), sul e centro-norte do Mato Grosso (MT), região do triângulo mineiro (MG) e Goiás (GO). Em 1990, a primazia da produção estava com a Região Sul, com destaque para RS e PR, que juntos respondiam por $55 \%$ das 19.897 .804 toneladas de soja produzidas no Brasil. O MT já aparecia com $15 \%$ da produção nacional, resultado da migração dos grãos no início da década de 1980. Nesse período já havia a percepção de que não seria possível comportar o crescimento da soja na estrutura fundiária da Região Sul, o que, consequentemente, indicara o deslocamento espacial da mercadoria para o norte, abrindo novas fronteiras, ainda na década de 1980, nos estados do Centro-Oeste (MT, MS e GO).

Em 2000 a espacialidade dos grãos se alterou significativamente, indicando que a soja se direcionou para o Centro-Oeste, processo que configurou a região como fronteira agrícola global (Costa Silva, 2015), que, tanto apresentou aumento da produção e produtividade, quanto gerou expectativa de incorporação de novas áreas ao agronegócio (soja, milho e, depois, cana-de-açúcar). No ano 2000, o Mato Grosso (27\%), Mato Grosso do Sul (8\%) e Goiás (12\%) respondiam por $47 \%$ da soja do Brasil, enquanto RS (15\%) e PR (22\%) representaram $37 \%$ da produção nacional (IBGE, 2019). Nesse ano, a região Nordeste já aparecia com a produção de 2.063 .859 de toneladas ( $6 \%$ da produção nacional), com destaque para os estados do Maranhão, Bahia e Piauí, que compõem a região do MATOPIBA. A região Norte exibiu números muito modestos, com apenas 184.614 de toneladas, todavia, já sinalizava o produto agrícola em experimentação com a potencialidade de se fazer da Amazônia uma fronteira dos grãos de soja (Alves, 2015; Costa Silva, 2005 e 2015).

Atualmente, quando se observa os números relativos à produção de soja (em 2018), a região Centro-Oeste assume a primazia desta com- 


\section{A caminho do Norte: cartografia dos impactos territoriais do agronegócio em Rondônia [Amazônia Dcidental]}

modity (Mapa 2), representando $45 \%$ da produção nacional, enquanto a região Sul produz 33\%, o que confirma a estabilização da produção e área produtiva no Sul do país. O que nos chama a atenção é o deslocamento da fronteira agrícola, que centralizada sobretudo no MT, agora se direciona aos estados do Nordeste (11.534.126 ton.; $10 \%)$ e Norte (5.467.676 ton.; $5 \%$ ), os quais somaram $15 \%$ da produção nacional.

A assunção do Nordeste como a nova fronteira agrícola foi cristalizada na formação dos polos agrícolas do sul do Maranhão, leste do Tocantins (região Norte), sul do Piauí e oeste da Bahia, cuja designação foi a região do MATOPIBA, dinâmica territorial do agronegócio que vários pesquisadores vêm indicando como uma nova regionalização nos cerrados do centro-norte do Brasil (Alves, 2015).

Mapa 2 - Produção (toneladas) e área (hectares) de soja no Brasil (2018).

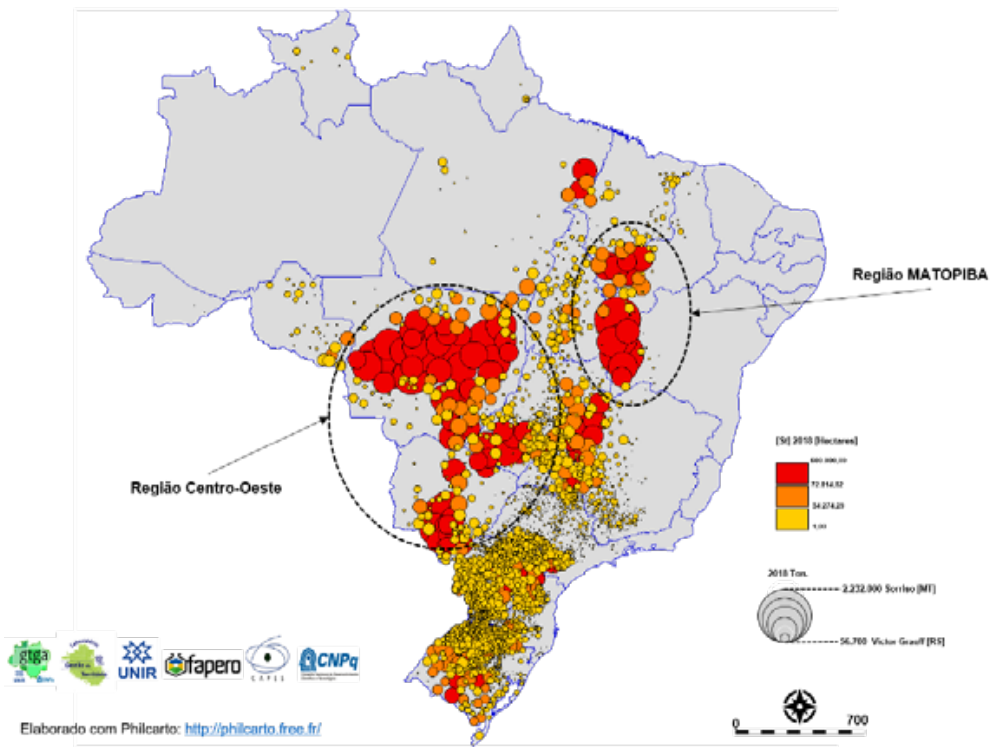

Fonte: IBGE - Produção Agrícola Municipal. Organização: Autores (RGCS/AM).

Portanto, sendo coerente com a periodização proposta, tem-se um primeiro período (1980/1990) representado pela produção de soja no Sul do país, produto da modernização dolorosa da agricultura brasileira iniciada nas décadas de 1960/1970 (Graziano da Silva, 1982), momento 


\section{Geografias de Rondônia Território, Fronteira e Educação}

em que a estrutura fundiária se manteve inalterada, com elevados índices de concentração da terra, abrindo-se à produção de monocultivos (soja e milho). No período posterior (1990/2000), com a primazia do Mato Grosso, o Centro-Oeste assume a condição de fronteira global de commodity, sendo a soja o "carro chefe" que consolida a região do agronegócio dos grãos e faz, ao mesmo tempo, deslocar a fronteira para regiões poucos aptas às monoculturas (Mapa 2).

A emergência de novas regiões agrícolas centralizadas pela soja será experenciada no período posterior ao ano 2000, quando o deslocamento da fronteira agrícola globalizada (Costa Silva, 2014) se direciona ao Nordeste brasileiro, que vai formar a região do MATOPIBA e, em menor escala, em áreas do Norte, especial em Rondônia, Tocantins e Pará, iniciando, a partir do Mato Grosso, uma pressão mais intensa na floresta amazônica.

A produtividade média da soja no Brasil, para o ano de 2018, foi de 3,4 toneladas por hectares. Em vários municípios (116) esse média foi extrapolada (4,22 ton./ha média), alcançando níveis satisfatórios bem superiores à produtividade nacional (Mapa 3). Utilizando uma escala de produtividade de 1 a 5 toneladas/hectares, as manchas de alta produtividade (vermelho) ocorrem tanto no Sul e Centro-Oeste, como nas novas fronteiras agrícolas, a exemplo do oeste da Bahia, norte do Mato Grosso, Maranhão, Piauí e Rondônia. Tal processo significa que a incorporação de novas áreas também está assentada nos processos tecnológicos que tendem a ampliar a escala geográfica dessas novas fronteiras, assim como, na ampliação dos conflitos agrários e territoriais (Ribeiro; Costa Silva; Correa, 2015; Costa Silva, Conceição, 2017). 


\section{A caminho do Norte: cartografia dos impactos territoriais do agronegócio em Rondônia [Amazônia Dcidental]}

Mapa 3 - Produtividade da soja no Brasil/toneladas por hectares (2018).

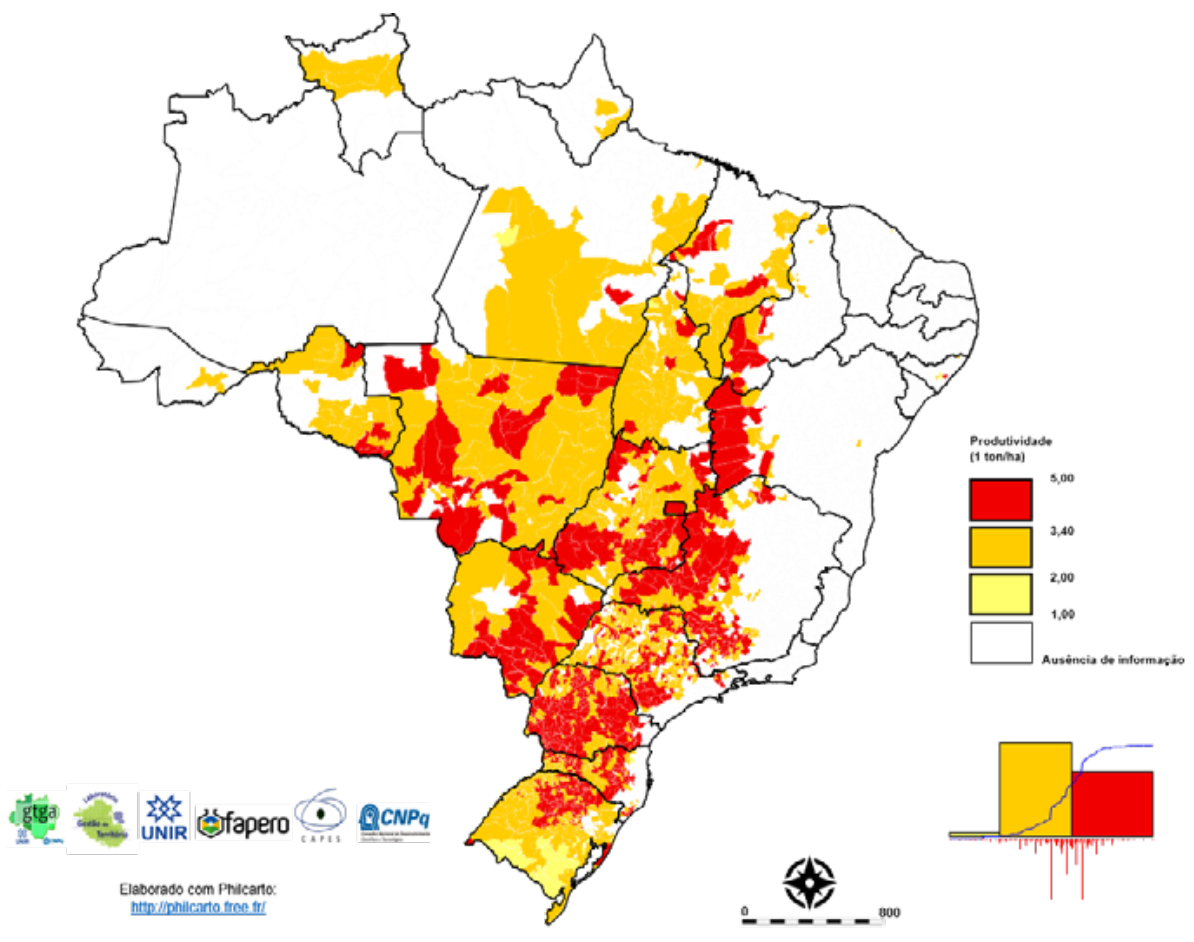

Fonte: IBGE - Produção Agrícola Municipal. Organização: Autores (RGCS/AM).

Se os dados agrícolas do mundo da soja colocam o Brasil como espaço nacional da economia internacional (Santos, 1996), configurando-o em fronteira agrícola globalizada (Costa Silva, 2015), certamente, esse "mundo" tende a se expandir nos lugares que lhe sejam forçosamente preparados. A região do MATOPIBA é um exemplo desse processo (Alves, 2015).

$\mathrm{Na}$ Região Norte, ainda que a produção de soja seja pouco representativa, se comparada aos números nacionais, nossa atenção se direciona aos impactos desse processo em escala local, quando os lugares e os municípios estão sendo solapados pela força avassaladora do agronegócio que desloca a fronteira na escala intra-estadual, empurrando a agropecuária para regiões próximas de áreas protegidas.

Nessa perspectiva cartográfica, verifica-se regiões da soja na Amazônia brasileira. Neste caso, a presença do Mato Grosso, como 


\section{Geografias de Rondônia Território, Fronteira e Educação}

fronteira global, nos permite pensar tanto sua centralidade e verticalidade, como também sua função enquanto centro difusor nacional, quando seus "tentáculos" penetram em toda a Amazônia. Assim, há forte produção de soja no sul do Maranhão e leste do Tocantins, ambos capturados pela formação do MATOPIBA; contudo, ainda que muito modesta, a soja também se direciona ao sudeste e oeste do Pará, sul e norte de Rondônia, cerrados de Roraima e Amapá, processo que se realiza no âmbito dos conflitos agrários, territoriais e do crime ambiental, como, particularmente, analisaremos em Rondônia.

\section{SOJA E DESLOCAMENTO DA FRONTEIRA EM RONDÔNIA}

Estudos realizados em Santarém (oeste do Pará) e Vilhena (sul de Rondônia) identificaram que o crescimento da soja se direciona em áreas do campesinato e nos limites de áreas protegidas (terras indígenas, terras quilombolas e Unidades de Conservação), concluindo que a espacialização desta commodity atingira os territórios protegidos e espaços do extrativismo comunitário, no qual ressalta-se as territorialidades dos povos e comunidades tradicionais amazônicas (Costa Silva; Conceição, 2017; Ribeiro; Conceição; Costa, 2015).

Especialmente no estado de Rondônia, objeto desta análise, a partir do ano de 1997/1998, o deslocamento da soja tem origem na pressão espacial do Mato Grosso, quando a procura por áreas aptas à produção de monocultivos, estrutura fundiária concentrada e preço da terra favorável convergiram à migração da soja para o sul rondoniense (Costa Silva, 2005; 2014). Em duas décadas houve um significativo crescimento da soja (Gráfico 1): a área plantada saiu de 7.892 para 278.533 hectares, e a produção cresceu de 15.791 para 908.702 toneladas no período de 1998/2017, o que representa a multiplicação na ordem de 35 vezes para a área e 58 vezes para a produção.

A produção de soja em Rondônia não é tão expressiva como ocorre nas áreas do Mato Grosso, ou mesmo em comparação com a nova fronteira agrícola do MATOPIBA, contudo, a questão que se impõe é da escala geográfica e dos impactos territoriais no espaço agrário rondoniense. Seus aspectos mais importantes mostram-se nas aceleradas transformações territoriais na escala regional, quando a regionalização da soja fez deslocar os fluxos econômicos para regiões mais preservadas, sem grandes pressões socioterritoriais da agropecuária, como atualmente ocorre no norte rondoniense (Costa Silva et al., 2017). 


\section{A caminho do Norte: cartografia dos impactos territoriais do agronegócio em Rondônia [Amazônia Qcidental]}

Gráfico 1 - Evolução da produção e área de soja em Rondônia (1990/2017)

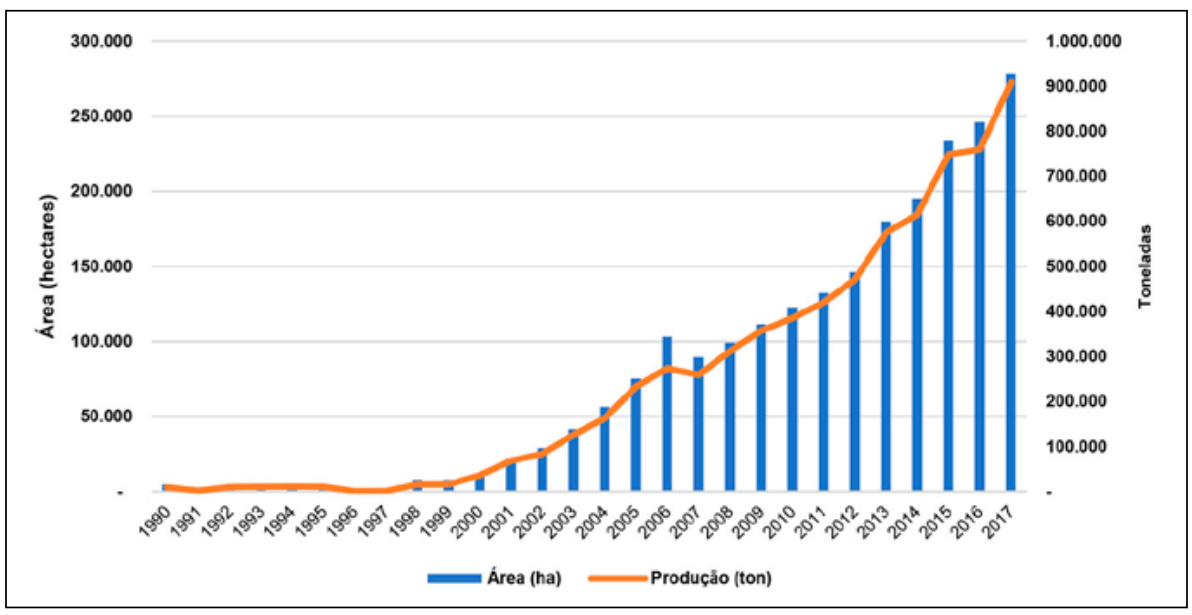

Fonte: IBGE - Produção Agrícola Municipal (2019). Organização: Autores (RGCS/AM).

De início, em Rondônia, a soja vai produzir a sua região, concentrando a produção no sul do Estado. A regionalização do agronegócio sojeiro foi o primeiro processo geográfico de diferenciação do espaço agrário de Rondônia (Costa Silva, 2014). Anteriormente, verificava-se no agrário rondoniense a ampla participação da pecuária como um processo geral de produção de mercadoria, somada à produção agrícola oriunda dos inúmeros projetos de assentamentos rurais, cujo circuito econômico estava circunscrito, em seu maior volume, ao comércio regional amazônico.

A produção de soja vai modificar a escala geográfica da circulação mercantil, na medida em que vai participar, perifericamente, do mercado global de commodities agrícolas. No mapa 4, nota-se que em 1998 somente cinco (5) municípios participavam da produção sojeira; duas décadas depois, o espaço da commodity ampliou-se para 32 dos 52 municípios rondonienses, o que serve como indicador, tanto da regionalização consolidada no sul rondoniense, quanto da constituição de novas fronteiras agrícolas. Com a concentração dos grãos (soja e milho) se formou um espaço corporativo (Costa Silva, 2005; Santos, 1996), principalmente da Amaggi (empresa do grupo Maggi) e Cargill, que juntas induziram, normatizaram e coordenaram a produção e a circulação da mercadoria no sul rondoniense. 


\section{Geografias de Rondônia Território, Fronteira e Educação}

Mapa 4 - Regionalização da soja em Rondônia (2017).

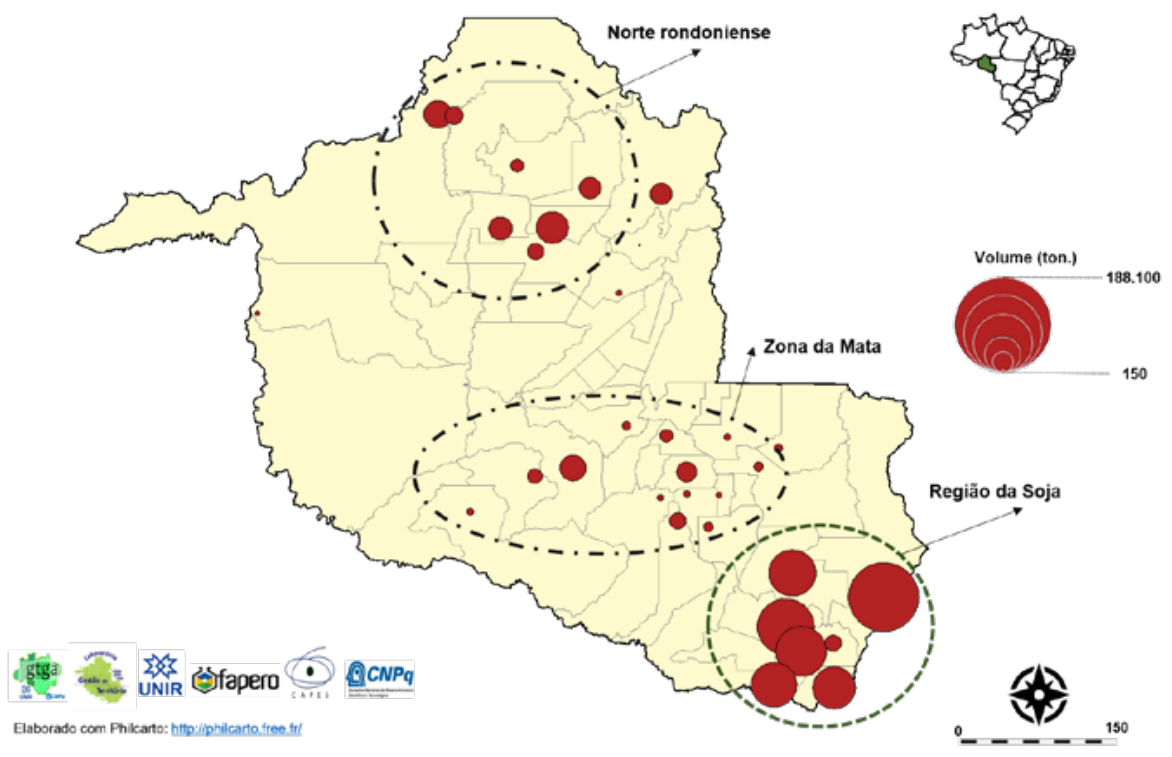

Fonte: IBGE - Produção Agrícola Municipal. Organização: Autores (RGCS/AM).

Evidentemente, a expansão da soja só alcançaria algum grau de sucesso se estivesse relacionada à logística (Becker, 1995), sobretudo a de transportes, condição necessária à fluidez territorial da mercadoria (Arroyo, 2001; Huertas, 2018). Assim, a inauguração da Hidrovia Madeira-Amazonas (1997), com os portos dos agentes hegemônicos do agronegócio (Hermasa/Maggi e Cargill), permitiu o fluxo da soja de Rondônia e do oeste do Mato Grosso pelo rio Madeira, ligando os portos de Porto Velho (RO) à Itacoatiara (AM), no trecho de 1.015 km (porto da Hermasa/Maggi), e à Santarém (PA), no trecho de 1.603 $\mathrm{km}$ (porto da Cargill), locais onde se fazem o transbordo para grandes navios que seguem ao mercado internacional (Costa Silva, 2005).

Por meio do Rio Madeira, o agronegócio abriu caminhos na Amazônia ocidental, sinalizando aos médios e grandes produtores que a logística de transporte inaugurava a fronteira globalizada em Rondônia, configurando-a como espaço da globalização (Santos, 1994; Costa Silva, 2005 e 2015), considerando que isso favoreceu a inversão de capital 


\section{A caminho do Norte: cartografia dos impactos territoriais do agronegócio em Rondônia [Amazônia Dcidental]}

no espaço agrário com vistas à territorialização da monocultura. Após duas décadas, a região da soja está consolidada em sete municípios (sul rondoniense), com produção de 657.808 toneladas $(72 \%$ da produção estadual).

Mas, a fronteira se desloca em duas direções no espaço regional, como visto no Mapa 3: primeiro, conforme dados de 2017, há o advento da produção da commodity no norte rondoniense, onde 11 municípios produziram 161.713 ton. (18\%); e, em menor escala, a região ampliada da Zona da $\mathrm{Mata}^{3}$, dos quais 14 municípios produziram 89.181 ton. (10\%) (IBGE, 2019). Em todo esse processo, a substituição de pastagens, o arrendamento de terra e o elevado preço do hectare de terra agrícola chancelam a marcha da soja. Contudo, o efeito espacial se traduz no deslocamento da pecuária para novas áreas, como veremos mais adiante.

Em todas essas regiões rondonienses, a marcha da soja produz conflitos agrários e territoriais, pressiona o campesinato, seja com aliciamentos nos arrendamentos de terras ou através dos impactos dos agrotóxicos, seja na valorização do preço da terra, causando "euforia” para uns e conflitos para outros (Ribeiro; Costa Silva; Correa, 2015; Costa Silva; Conceição, 2017; Ricarte, 2017). No que se refere às grandes propriedades, o agronegócio converteu áreas de pastagens em espaços da monocultura favorecido pela estrutura fundiária do sul rondoniense, caracterizada pela presença de latifúndios e por conflitos agrários, como ocorreu em 1995 na fazenda Santa Elina, município de Corumbiara, que ficou conhecido na história como Massacre de Corumbiara.

A conversão de pastagens à soja capitalizou os grandes proprietários (pecuaristas) e empresas agropecuárias com a venda ou arredamentos de terras. O resultado se mostra no contínuo deslocamento da fronteira em Rondônia em direção às sub-regiões norte rondoniense e Zona da Mata, que incorpora a fronteira com a Bolívia. Nos caminhos do capital agrário, o deslocamento espacial se faz em terras devolutas

\footnotetext{
3 “Zona da Mata” corresponde a qualificação dada pelos migrantes/colonos que vieram para Rondônia na década de 1970 e ocuparam a região do atual município de Rolim de Moura. Na época da colonização, a então localidade de Rolim de Moura pertencia ao município de Cacoal, sendo reconhecida pela crescente economia madeireira que movimentava a fronteira. A grandiosidade da floresta "inspirou” a designação de região Zona da Mata, que até hoje é utiliza na mídia regional e na propaganda governamental (Costa Silva, 2012).
} 


\section{Geografias de Rondônia Território, Fronteira e Educação}

(áreas da União não destinadas, mas ocupadas irregularmente, principalmente por grileiros) e em áreas protegidas (Unidades de Conservação, Terras Indígenas e Terras Quilombolas). Isso significa que o agronegócio da soja impulsionou a migração populacional intrarregional (campo-cidade/campo-campo), deslocando e potencializando a fronteira agrícola.

A regionalização da soja "empurrou" a pecuária e, consequente, a demanda por terra em sub-regiões rondonienses que não estavam pressionadas pela economia agrícola (pecuária, agricultura e terra). Essa é a situação geográfica no norte rondoniense, no município de Porto Velho, capital do estado de Rondônia, que analisaremos, especificamente, no próximo subtema.

\section{EXPANSÃO DA FRONTEIRA INTERNA EM RONDÔNIA: ANÁLISE DE UNIÃO BANDEIRANTES}

$\mathrm{Na}$ seção anterior demonstramos a regionalização da soja e as frentes de expansão da fronteira em Rondônia, indicando os caminhos do agronegócio em sub-regiões que, a priori, não estavam no "radar" desta economia agrícola. Aprofundaremos a abordagem analisando uma situação geográfica no norte Rondoniense, na região do então povoado de União Bandeirantes, onde migração populacional, desmatamento, agropecuária e pressões nas áreas protegidas compõem os vetores das dinâmicas agrárias e territoriais.

Lembramos que Rondônia foi o primeiro Estado da Amazônia Legal a instituir o Zoneamento Socioeconômico Ecológico (ZSEE), então considerado, na década de 1990, como o mais moderno instrumento de gestão do território para a região amazônica. Evidentemente, para o sucesso da gestão do território, é mister a ação coordenada do Estado no desenvolvimento de políticas econômicas, sociais e ambientais articuladas para que o espaço ordenado possa ser um balizador das ações da sociedade (Rondônia, 2010; Costa Silva, 2016).

Em síntese, o Zoneamento é a pactuação da sociedade em ordenar o uso do território. Os processos socioespaciais podem conter escalas diferentes e a "vigilância" para com o espaço ordenado atribui ao Estado o permanente monitoramento das dinâmicas territoriais e agrárias que, contemporaneamente, anunciam vetores externos, exógenos ao cotidiano dos lugares. São fluxos externos que se internalizam nos lugares e territórios, subvertendo a lógica endógena, a ordem local (Santos, 1996). A perspectiva teórica do espaço nos permite compreender que o 


\section{A caminho do Norte: cartografia dos impactos territoriais do agronegócio em Rondônia [Amazônia Dcidental]}

agronegócio da soja representa um dos fluxos externos que se internalizaram em Rondônia, sendo, portanto, um elemento tensionador, modificador e indutor das dinâmicas agrárias e territoriais vigentes, no qual, União Bandeirantes é a expressão mais concreta dessa geografia das fronteiras. Subdividiremos a análise em três eixos: migração e formação da agrocidade $^{4}$, que se baseia na existência de uma forte interligação entre campo e cidade; produção agropecuária e exploração madeireira; gestão do território, áreas protegidas e desmatamento.

\section{UNIÃO BANDEIRANTES E A FORMAÇ̃̃o DE UMA AGROCIDADE EM MEIO À FLORESTA}

A migração faz parte da formação socioespacial de Rondônia, que na década de 1970 recebeu milhares de colonos, migrantes do Centro-Sul do Brasil, com a expectativa de acesso à terra, motivados pela política de colonização agrícola executada pelo Instituto Nacional de Colonização e Reforma Agrária (Incra).

Esse processo demográfico, de escala inter-regional, deu os primeiros contornos à configuração territorial de Rondônia. Cinco décadas depois, a migração perdeu potência, as cidades e a rede urbana cresceram e as dinâmicas migratórias restringiram-se à escala intra-estadual, prevalecendo mais o sentido campo-cidade e pouco campo-campo (Costa Silva et al., 2017). Contudo, no norte rondoniense há processos migratórios em direção ao campo e aos pequenos municípios, sendo uma das expressões da migração populacional na escala intra-estadual, no qual, União Bandeirantes, é manifestação dessa geografia.

A migração de famílias camponesas para área devoluta da União, nos anos 1999/2000, deu início à vila de União Bandeirantes, localizada a $160 \mathrm{~km}$ da cidade de Porto Velho, capital do estado de Rondônia.

\footnotetext{
${ }^{4}$ Provisoriamente, qualificamos de agrocidade a formação de pequenos núcleos urbanos, em geral não planejados, que surgem em função da expansão da fronteira agrícola. Os sujeitos desse processo são os proprietários de terras, madeireiros, comerciantes, camponeses expropriados e pequenos proprietários que buscaram adquirir terras na perspectiva de ampliar e melhorar suas vidas. As agrocidades apresentam um comércio vinculado à agropecuária e a exploração de algum recurso natural que possa movimentar a economia da fronteira, que no caso se verifica com a exploração ilegal de madeira. Em função da dinâmica socioeconômica, não podem ser consideradas como vilas rurais e, ao mesmo tempo, não alcançaram o estatuto de cidade.
} 


\section{Geografias de Rondônia Território, Fronteira e Educação}

Passadas quase duas décadas, União Bandeirantes deixou de ser uma vila para se tornar uma pequena cidade, uma agrocidade, com equipamentos urbanos mínimos, economia local vinculada ao comércio, agropecuária e setor madeireiro.

Em termos de gestão do território esta agrocidade ainda não alcançou nem o estatuto de distrito de Porto Velho, muito embora sua dinâmica socioeconômica já lhe credencie a ser um município, dado o porte de pequena cidade que assume atualmente. Conforme o último Censo Demográfico, o IBGE classificou União Bandeirantes como um aglomerado rural $^{5}$, a priori, pois cabe à Prefeitura de Porto Velho a gestão do território, designando bairros e distritos, o que significa que o Censo não captou os indicadores socioeconômicos mais detalhados dessa cidade em formação.

Se as estatísticas oficiais estão defasadas, não captando o fenômeno geográfico em curso, a dinâmica urbana se acelera em meio à floresta, podendo esta agrocidade ser comparada com as métricas de outros municípios. Estima-se que a população da cidade alcance 15 mil pessoas, com mais 10 mil pessoas no campo, totalizando 25 mil habitantes em União Bandeirantes (Costa Silva, 2016). Se comparamos com alguns dados da geografia populacional de Rondônia, que tem 52 municípios, temos os seguintes números: em 27 municípios rondonienses, a população total não ultrapassa 25 mil habitantes; em 38 municípios, a população urbana não atinge 14 mil habitantes; e em 42 municípios, a população rural não ultrapassa 10 mil pessoas. Ou seja, a invisibilidade das estatísticas oficiais não dá conta da dinâmica territorial de União Bandeirantes que já apresenta as condições, em termo populacionais, semelhantes a 27 municípios rondonienses.

\footnotetext{
${ }^{5}$ Segundo o IBGE (2010, p. 19-21), define-se aglomerado rural como uma "localidade situada em área legalmente rural, onde existam unidades domiciliares que conformem um conjunto de edificações adjacentes (50m ou menos de distância entre si) com características de permanência”. [São classificados como rural do tipo extensão urbano, povoado e núcleo]. Povoado - é um aglomerado rural sem caráter privado ou empresarial, ou seja, não vinculado a um único proprietário do solo (empresa agrícola, indústrias, usinas, etc.), cujos moradores exercem atividades econômicas, quer primárias (extrativismo vegetal, animal e mineral; e atividades agropecuárias), terciárias (equipamentos e serviços) ou, mesmo, secundárias (industriais em geral), no próprio aglomerado ou fora dele. $\mathrm{O}$ povoado é caracterizado pela existência de um número mínimo de serviços ou equipamentos para atender aos moradores do próprio aglomerado ou de áreas rurais próximas.
} 


\section{A caminho do Norte: cartografia dos impactos territoriais do agronegócio em Rondônia [Amazônia Dcidental]}

Evidentemente, a migração é fator determinante nesse processo espacial que, entretanto, assume a escala intra-estadual, ou seja, as famílias que ocuparam a região e que formaram a cidade e o campo são oriundas dos grandes e pequenos municípios de Rondônia. Muitas delas já haviam passado por outros processos de migração na escala intra-estadual, uma vez que a história regional de Rondônia é marcada pelo processo de migração inter-regional e intraestadual (Valverde, 1979; Costa Silva, 2012).

Dado a esse processo, indica-se que a fronteira não consegue "segurar" os moradores locais, ou seja, há um encurtamento temporal nos lugares de moradia e de trabalho para os grupos sociais mais vulneráveis economicamente, o que resulta em uma aceleração da mobilidade espacial desses sujeitos. Essa vulnerabilidade se expressa na necessidade do campesinato migrar como um processo "espontâneo", atingido pelos efeitos do agronegócio que pressiona esses e outros grupos sociais, como por exemplo, os seringueiros, a buscarem outros espaços de reprodução social, econômica e política, considerando que a fronteira se transforma em espaço-mercadoria do capital agrário (Mapa 5).

A maioria dos migrantes se deslocou da região central de Rondônia para União Bandeirantes, especialmente dos municípios de Jaru, Ouro Preto, Mirante da Serra e Ji-Paraná (Mapa 5). Deve-se registrar que esses municípios formaram a primeira região da colonização agrícola (1970/1990) e de institucionalização de assentamentos rurais, compondo o "berço" da migração em Rondônia (Théry, [1976]2012; Valverde, 1979; Coy, 1987). 


\section{Geografias de Rondônia Território, Fronteira e Educação}

Mapa 5 - Origem/nascimento da população de União Bandeirantes (2016).

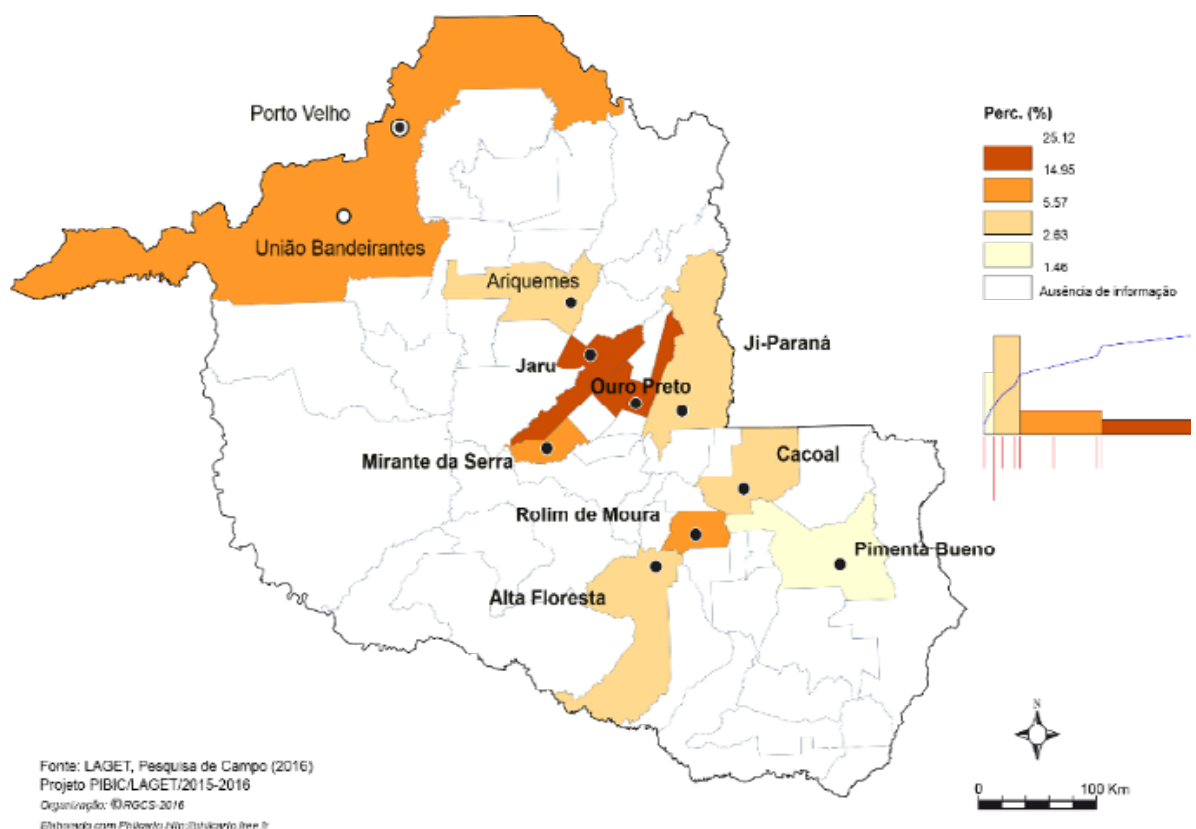

Fonte: Pesquisa de campo, PIBIC/UNIR/Laget. Organização: Autores (RGCS/AM).

Segundo dados levantados em trabalho de campo, os fatores que levaram à migração se relacionam à expectativa de trabalho, renda, acesso à terra urbana e rural, e perspectiva positiva em melhoria da vida familiar. Ao verificarmos que $85 \%$ dos moradores nasceram em Rondônia, nos municípios e região sede da colonização, significa que, possivelmente, estes são filhos dos migrantes que chegaram nas décadas de 1970/1980. Neste caso, viveram a multiespacialidade do campo e da cidade na área de colonização, indicando que a sobrevivência e a permanência de trabalhadores encontram graus de dificuldades para se manterem nos lugares de origem. Assim, a migração intra-estadual também se mostra como saída econômica quando o ato de migrar atende à expectativa de melhorias sociais e de acesso à terra na expansão da fronteira.

Os municípios de origem dos migrantes são fortes na pecuária de corte e leite, sendo a criação de gado o principal produto do campo. Em diálogo com os moradores de União Bandeirantes, muitos depoimen- 


\section{A caminho do Norte: cartografia dos impactos territoriais do agronegócio em Rondônia [Amazônia Qcidental]}

tos nos indicaram que o preço da terra, somado à estrutura fundiária, com propriedades abaixo de 20 hectares, apresentava limites à produção agropecuária caso não se aportassem investimentos e tecnologias nos processos produtivos. Nessas situações, o preço da terra elevado era o maior patrimônio das famílias, sobretudo pelo aumento da pecuária, que, ao tempo em que valoriza a terra, impulsiona a concentração fundiária.

Para muitos, o caminho da cidade não era a melhor escolha, dadas as dificuldades e limitações do mercado de trabalho, além do custo de vida urbano. A valorização do preço da terra na região Central de Rondônia, cuja cidade polo é Ji-Paraná, se deve ao crescimento do rebanho bovino e ao deslocamento da pecuária extensiva da região do agronegócio da soja. A soja, ao converter pastagem em terra agrícola dos grãos (soja e milho), capitalizou os grandes proprietários que, por sua vez, passaram a expandir a pecuária nas demais sub-regiões rondonienses. O produto espacial desse processo foi a "pecuarização", aumento do preço da terra e migração dos pequenos, médios e grandes proprietários para áreas devolutas no estado de Rondônia, no qual a região de União Bandeirantes é resultado/efeito do processo territorial do agronegócio da soja.

\section{AgropeCUÁRIA, INDÚSTRIA MADEIREIRA E DESMATAMENTO}

No período de 18 anos, União Bandeirantes se afirmou como a maior região agrícola do município de Porto Velho. A produção agrícola e pecuária, em sua maioria sob a gestão de pequenos proprietários, famílias camponesas que saíram da região central de Rondônia, cresceu significativamente.

A pecuária é o "carro chefe" da economia da fronteira, dentre outras questões, por ser uma poupança móvel, com maior liquidez e com mercado permanente. As trocas mercantis se efetivam com os compradores de gado, frigoríficos, grandes pecuaristas e com os pequenos proprietários. É a pecuária extensiva e a agricultura familiar (pequenos agricultores) que movimentam a fronteira.

Em União Bandeirantes (Mapa 6), o rebanho bovino representa $19 \%$ da pecuária (180.000 bovinos) do município de Porto Velho, produzido em 33\% dos estabelecimentos (1.814 unidades) destinados à criação de gado do mesmo município. Se incluirmos nas métricas o rebanho da região de Rio Pardo, outro "distrito" formado em meio à floresta, 


\section{Geografias de Rondônia Território, Fronteira e Educação}

significa adicionar 171.000 bovinos em 1.021 estabelecimentos agropecuários, o que nos permite apresentar os seguintes dados: 351.000 cabeças de gado produzidas em 2.835 propriedades, o que representa, respectivamente, $36,17 \%$ do rebanho e $51,16 \%$ das propriedades rurais do município de Porto Velho (IBGE, 2019; Idaron, 2019). A agropecuária movimenta a fronteira, garantindo trabalho e renda a milhares de famílias, em sua maioria estabelecida numa malha fundiária de pequenas propriedades.

Mapa 6 - Áreas Protegidas na região de União Bandeirantes

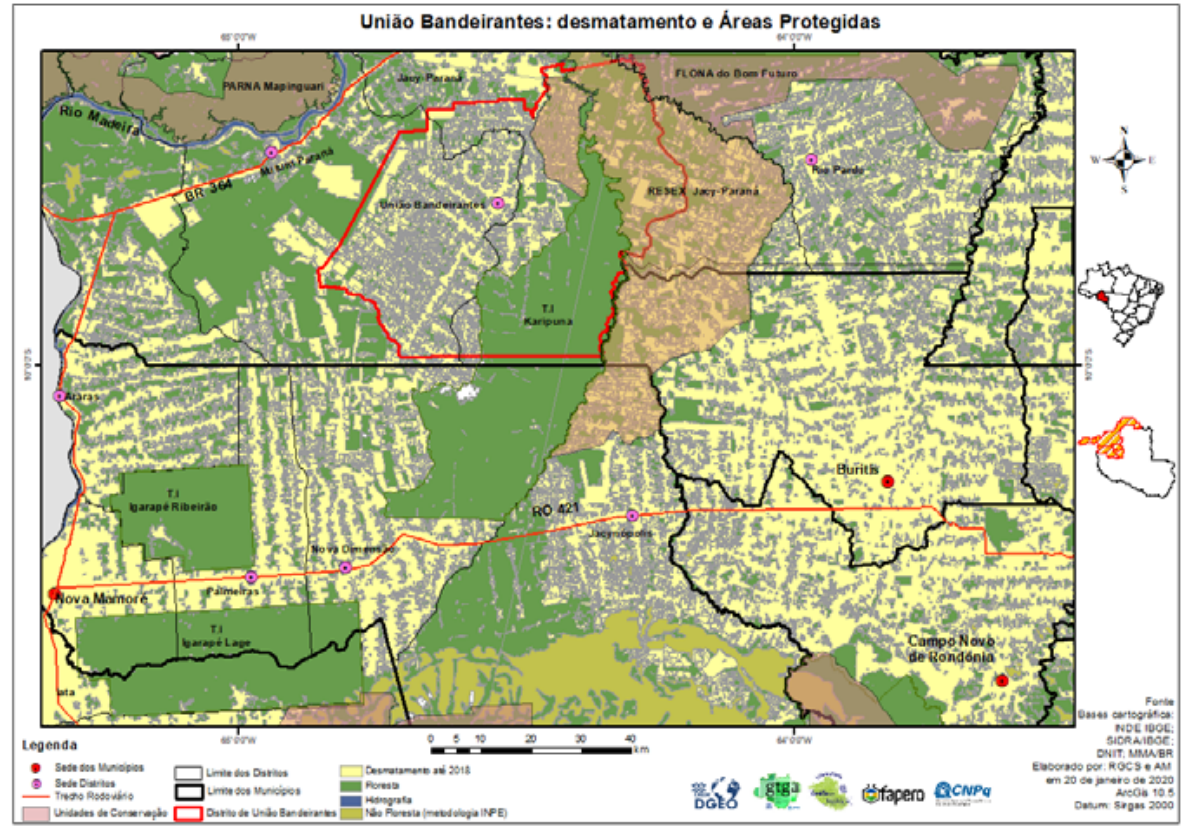

Fonte: Autores (RGCS/AM), 2019.

Antes da pecuária, outra economia extrativa se encarrega de abrir os espaços na floresta. Trata-se da exploração madeireira, atividade econômica que faz a linha de frente da expansão da fronteira. No Mapa 6 podemos observar o tensionamento e o avanço do desmatamento em consequência da expansão da fronteira para o norte de Rondônia, onde se localizam áreas protegidas, a exemplo do Parque Estadual GuajaráMirim, Resex Jacy-Paraná e as Terras Indígenas Igarapé Lage e Igarapé 


\section{A caminho do Norte: cartografia dos impactos territoriais do agronegócio em Rondônia [Amazônia Dcidental]}

Ribeirão, além da Terra Indígena Karipuna, que apresenta grande parte de sua área no município de Porto Velho.

No início da formação de União Bandeirantes, a extração madeireira apresentava grande dinamismo, isso porque, nos primeiros anos de ocupação, somavam-se mais de 60 serrarias instaladas na localidade. No ano de 2017, em trabalho de campo, identificamos seis serrarias em funcionamento (Figuras 1 e 2). Na figura 2 estão pontuadas as seis serrarias que ainda mantinham seus pátios em funcionamento e suas fornalhas acessas até o mês de junho de $2019^{6}$, demonstrando que o comércio madeireiro ainda estava ativo, sendo essa uma das características das áreas de expansão da fronteira.

Figura 1 - Indústria madeireira em União Bandeirantes (2017).

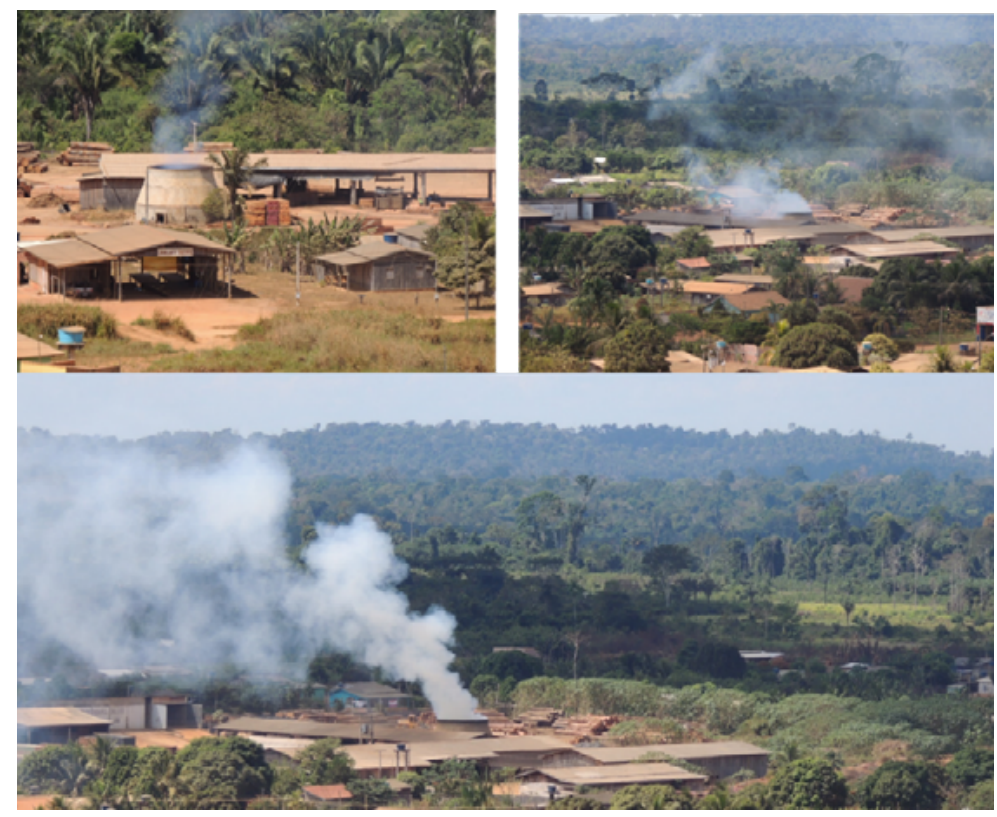

Fonte: GTGA (Trabalho de campo em dezembro de 2017). 


\section{Geografias de Rondônia Território, Fronteira e Educação}

Figura 2 - Localização das seis serrarias em funcionamento em União Bandeirantes (até o mês de junho de 2019).

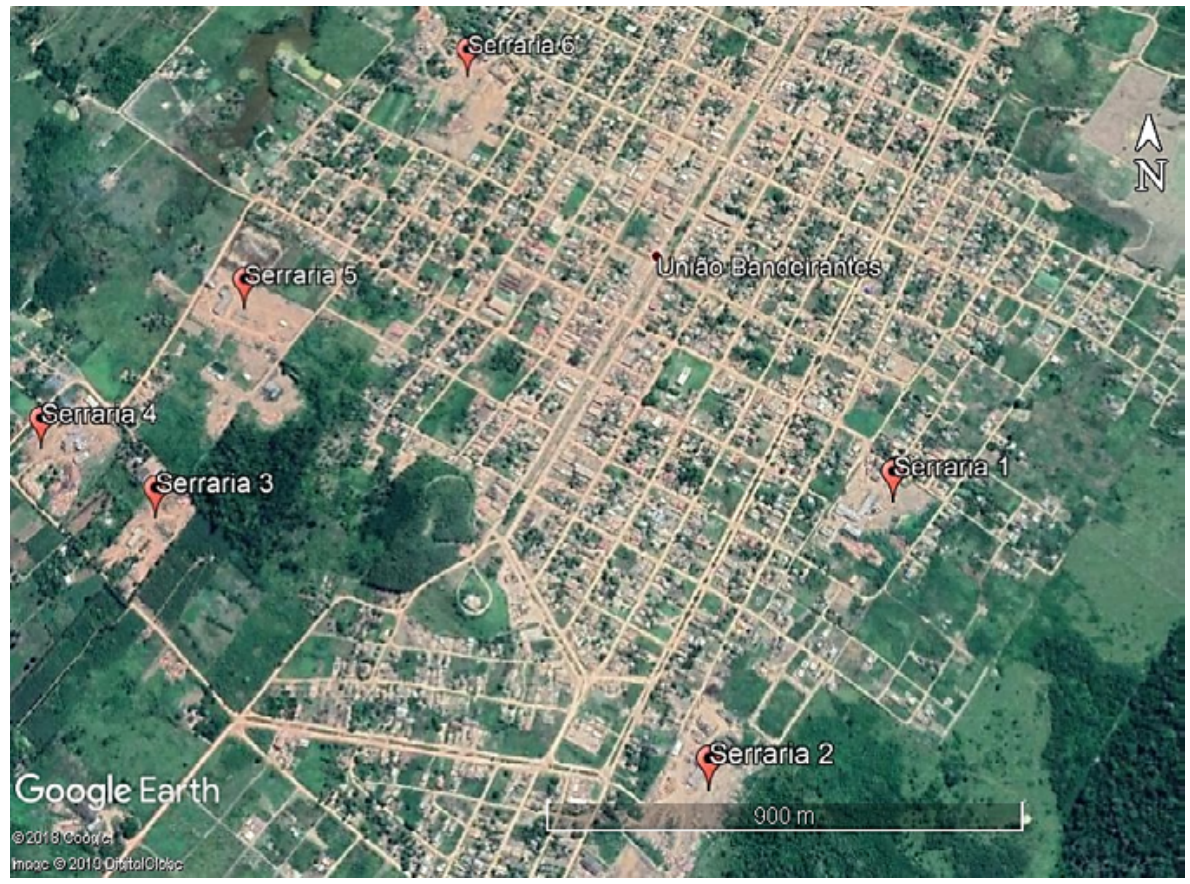

Fonte: Google Earth PRO. Organização: Autores (RGCS/AM) (janeiro de 2019). Disponível em: www.google.com/maps/@-9.714006,-64.5315528,1423m/data=!3m1!1e3.

A exploração madeireira na região amazônica, segundo o relatório apresentado pelo Pnuma ${ }^{7}$ no ano de 2012, pode estar relacionada ao comércio irregular de carbono verde. Esse estudo apontou que de 50 a $90 \%$ das extrações de madeira nos países tropicais acabam sendo realizadas pelo crime organizado. Neste relatório são identificadas fraudes relacionadas ao sistema de licenças das madeiras extraídas, algumas delas, inclusive, retiradas de Terras Indígenas por meio da adulteração de planos de manejos, verdadeira "lavagem de madeira" (Augusto, 2012).

Alguns proprietários de madeireiras apresentam áreas com maior cobertura vegetal no processo de licenciamento ambiental, cujo limite de

\footnotetext{
${ }^{7}$ Programa das Nações Unidas para o Meio Ambiente (Pnuma).
} 


\section{A caminho do Norte: cartografia dos impactos territoriais do agronegócio em Rondônia [Amazônia Dcidental]}

exploração, segundo o Código Florestal, é de 30 metros cúbicos por hectare da propriedade rural. Essas áreas já apresentam desmatamento e, por ineficácia da gestão estadual, a licença é fornecida, ocorrendo então a exploração de "árvores fantasmas", considerando que elas não existem nos locais indicados para exploração da madeira. Como resultado, essas árvores são retiradas de outros locais, como atualmente ocorre na Resex Jacy-Paraná e na Terra Indígena Karipuna, na região de União Bandeirantes, sendo comercializadas de forma "legal", por meio dos licenciamentos falhos (Michalski, 2018; Brancalion et al., 2018).

Gráfico 2 - Exploração madeireira na microrregião de Porto Velho (1996 a 2016).

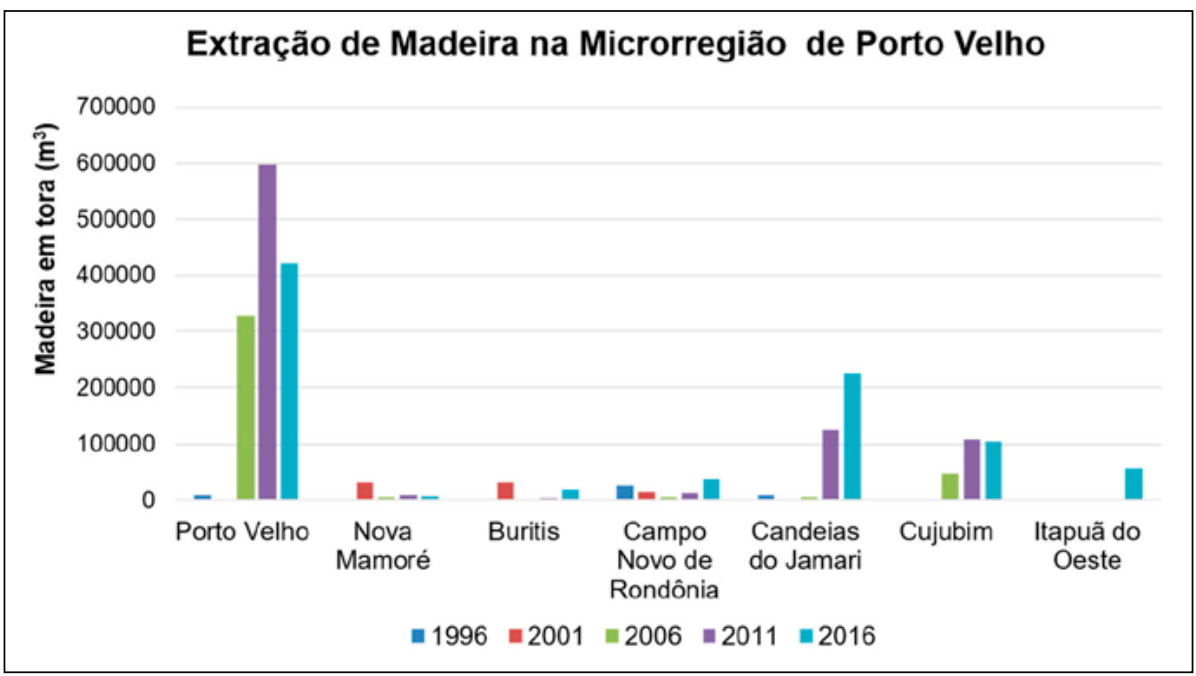

Fonte: IBGE/Sidra (2018); Organização: Michalski, 2018.

A análise pode ser feita por meio dos dados da extração de madeira (em toras) em Rondônia, no período de 1996 a 2016. Os dados indicam a relação direta entre extração madeireira e consequente aumento do desmatamento no município de Porto Velho. Nesse período, a microrregião de Porto Velho se destaca, no ano de 2011, com 600 mil metros cúbicos extraídos. No Gráfico 2, verifica-se a evolução da extração de madeira, em toras, na microrregião de Porto Velho, que apresenta maior relevância no estado de Rondônia. 


\section{Geografias de Rondônia Território, Fronteira e Educação}

Porto Velho, conforme podemos observar no gráfico 2, apresenta maior quantitativo de extração madeireira, que segundo o IBGE, ocorreu de forma legal, mas ao compararmos os dados do desmatamento, inclusive em reservas florestais e áreas indígenas, com o avanço da pecuária para o norte de Rondônia, constatamos uma forte correlação das variáveis, desmatamento e aumento da pecuária. Essa correlação pode ser verificada no Gráfico 3.

Gráfico 3-Correlação com o coeficiente de Pearson (pecuária e desmatamento).

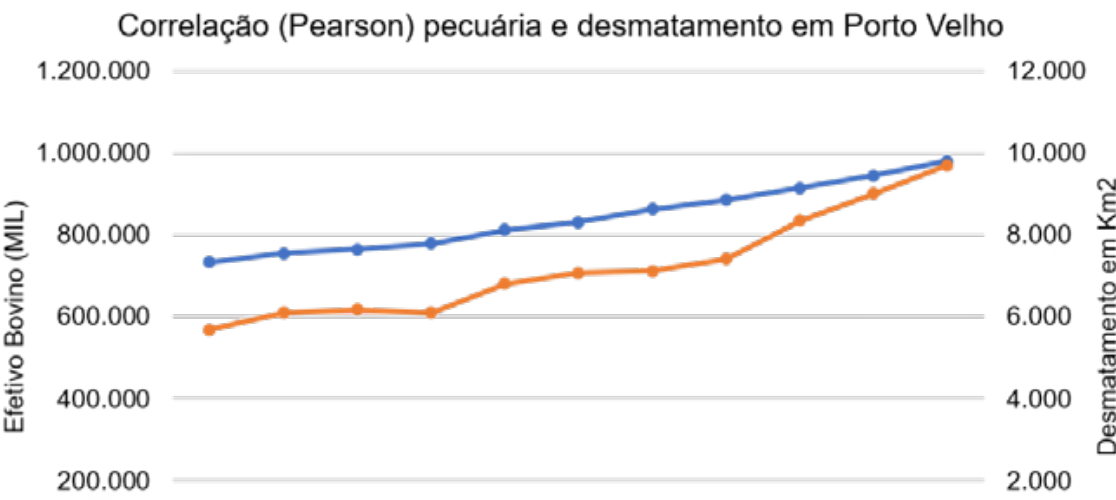

20072008200920102011201220132014201520162017

$\rightarrow$ Desmatamento $\rightarrow$ Rebanho 0,98

Fonte: Prodes e IBGE (2017); Organização: Michalski, 2018.

Com base nas informações do Gráfico 3, utilizando o coeficiente de Pearson, que busca identificar correlações entre as variáveis pecuária bovina e o desmatamento, mostra-se que o valor de $r$ atinge 0,98, demonstrando um forte grau de correlação positiva, ou seja, uma variável interfere na outra. Ao longo dos últimos anos são constantes as apreensões de madeira extraídas de forma ilegal no município de Porto Velho, na Terra Indígena Karipuna e, principalmente, da Reserva Extrativista Jacy-Paraná, Unidade de Conservação que apresenta aproximadamente $50 \%$ de área desmatada (Santana; Silva, 2019). 


\section{A caminho do Norte: cartografia dos impactos territoriais do agronegócio em Rondônia [Amazônia Dcidental]}

A Terra Indígena Karipuna tem aproximadamente 10 mil hectares desmatados, fruto da ação ilegal dos madeireiros e grileiros de terras públicas. Segundo os dados do Programa de Monitoramento do Desflorestamento da Amazônia (Prodes), entre os anos de 2015 e 2017 ocorreram os maiores índices de desmatamento dentro da T.I Karipuna, sendo esse período responsável por $40 \%$ do total degradado até o ano de 2017 (CIMI, 2019).

\section{GESTÃO DO TERRITÓRIO E ÁREAS PROTEGIDAS}

Inicialmente, a ocupação da região de União Bandeirantes foi objeto das famílias camponesas, pequenos proprietários e famílias oriundas das cidades. Posteriormente, esse processo se deslocou para a chancela dos grupos madeireiros, pecuaristas/fazendeiros e grileiros. Rapidamente, esses grupos, em conluio ou em ação individual, iniciaram o processo de invasão de terras públicas devolutas e áreas protegidas (Mapa 7), ampliando o desmatamento do município de Porto Velho.

Mapa 7 - Região de União Bandeirantes e Áreas Protegidas (2018).

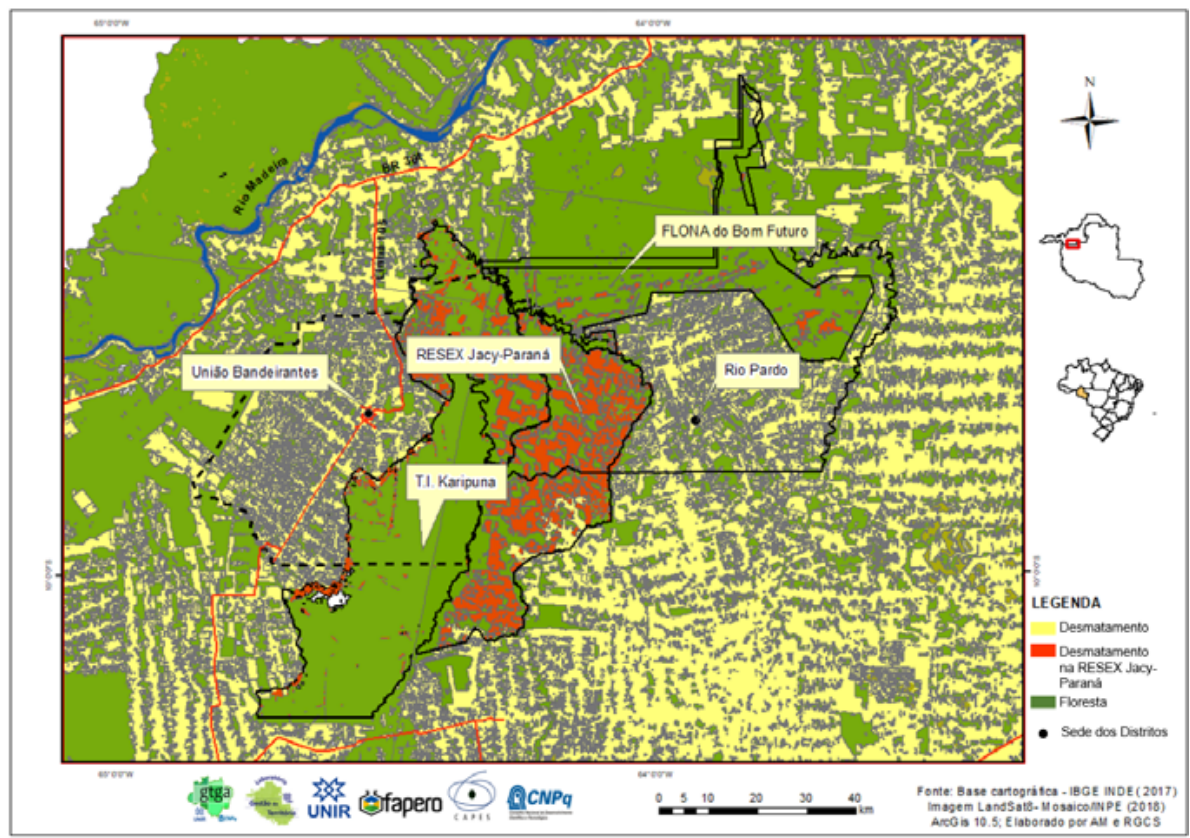

Fonte: Organização: Autores (RGCS/AM). 


\section{Geografias de Rondônia Território, Fronteira e Educação}

A região de União Bandeirantes é composta por áreas protegidas que estão sendo objeto de pilhagem ambiental. Tem-se a Reserva Extrativista de Jacy-Paraná (196.897ha.) e a Terra Indígena Karipuna (153.000ha.). Nas adjacências há a Floresta Nacional do Bom Futuro e a Terra Indígena Karitiana.

Desde o ano 2000, o processo de desmatamento se tornou mais intenso no município de Porto Velho, o que configurou a região de União Bandeirantes como a mais expressiva expansão da fronteira agrícola em Rondônia. No período de 2000 a 2018, o desmatamento avançou vertiginosamente em Porto Velho, saindo de $3.888,30 \mathrm{~km}^{2}(11,23 \%$ de desmatamento) para $10.199,60 \mathrm{~km}^{2}(29,45 \%)$ de desmatamento, cuja taxa de variação foi da ordem de $162,32 \%$. Nesse período, Porto Velho passou a compor a relação anual dos municípios da Amazônia Legal que contribuíram no incremento do desflorestamento. Os dados indicam que $62 \%$ do desmatamento em Porto Velho ocorreu no recente período de expansão da fronteira agrícola em Rondônia.

A passividade do Estado (governos de Rondônia, Federal e suas agências de gestão ambiental e territorial) proporcionou esse processo devastador. Muitos agentes públicos tiveram interesses políticos ao apoiar o avanço da fronteira em áreas de florestas e Unidades de Conservação. O exemplo mais concreto dessa "passividade" em conter a pressão das madeireiras e grileiros em áreas protegidas foi a invasão irreversível que terminou na redução de $65 \%$ da área original da Flona do Bom Futuro.

Os grupos organizados descritos acima, à revelia do ordenamento territorial e com a passividade do Estado (federal e estadual), ocuparam e "demarcaram" terras na área rural de União Bandeirantes, inclusive na zona de amortecimento da Resex e nos limites da Terra Indígena Karipuna. $\mathrm{Na}$ atualidade, estas áreas protegidas apresentam as seguintes situações: a Resex Jacy-Paraná está com quase $50 \%$ da área desmatada, totalmente pressionada com invasões, sobretudo dos pecuaristas/fazendeiros, o que torna mais difícil sua reversibilidade. Trata-se de uma Unidade de Conservação muito fragilizada, inclusive com desterritorializações dos seringueiros; já a Terra Indígena Karipuna, nos últimos três anos, experimenta frequentes invasões, roubo de madeiras e tentativas de grilagem de terra.

No período de duas décadas, a expansão da fronteira ocorreu com a conversão de áreas naturais e protegidas (ordenamento territorial) em espaço da agropecuária, que funcionou, e ainda funciona, como 


\section{A caminho do Norte: cartografia dos impactos territoriais do agronegócio em Rondônia [Amazônia Qcidental]}

reserva espacial do agronegócio. A lógica territorial do agronegócio, que em Rondônia assenta-se na soja e na pecuária extensiva, articula-se tanto a modernização agrícola quanto a pressão territorial em áreas protegidas, compondo, no mesmo processo, modernização, tecnologia, violência e crime ambiental.

$\mathrm{O}$ avanço da fronteira traz sérias ameaças e pressões às áreas protegidas, cujo dado relevante é a sobreposição de imóveis rurais sobre Terras Indígenas. O município de Porto Velho apresenta, segundo dados do Sistema Nacional de Cadastro Ambiental Rural (Sicar), 19.733,79 hectares de imóveis rurais sobrepostos em Terras Indígenas. Nova Mamoré, município do noroeste/norte do estado de Rondônia, apresenta 165.474,35 hectares de áreas com sobreposição, sendo a maior extensão sobreposta do estado de Rondônia. Porto Velho e Nova Mamoré, com base nos dados fornecidos pelo Sicar, representam 33,88\% do total de áreas sobrepostas em Rondônia, ou seja, propriedades agropecuárias em Terras Indígenas.

\section{CONSIDERAÇÕES FINAIS}

O mundo agrário brasileiro tem no crescimento das commodities o seu "carro chefe", que lhe credencia a participar da globalização econômica. Dentre as principais mercadorias agrícolas, a soja é a que, nas últimas décadas, vem apresentando uma dinâmica territorial expansiva, sempre na busca por novas áreas agrícolas, incorporando lugares e territórios, o que termina por mover as fronteiras internas no Brasil.

Como demonstramos, a cartografia da soja indica que seu movimento espacial caminha para o norte do Brasil. Nas décadas de 1960/1970/1980, a região Sul foi o espaço embrionário desta monocultura que cresceu no âmbito da modernização dolorosa, momento em que a expropriação camponesa foi mais acentuada. Nas décadas de 1990/2000 é o Centro-Oeste que assume a centralidade territorial da produção nacional dos grãos (soja e milho), tornando-se um celeiro no mercado mundial de grãos, com proeminência do Mato Grosso. O preço das commodities e a demanda por terras faz movimentar a fronteira na lógica de incorporação dos lugares ao mundo da soja. Esse processo atinge com mais intensidade a região do MATOPIBA (2000/2018), o que vários autores já indicam tratar-se, a partir da agricultura globalizada, de uma nova regionalização. 


\section{Geografias de Rondônia Território, Fronteira e Educação}

A Amazônia brasileira também foi atingida pelas fronteiras da soja. Em se tratando de região Norte, verifica-se quatro polos da soja que ameaçam a floresta, áreas protegidas, assentamentos rurais e territórios tradicionais. No Pará, a soja se insere no sudeste paraense (município de Paragominas) e oeste (Santarém). Em Tocantins, influenciado pelos vetores do agronegócio do Centro-Oeste, os grãos apresentam produção considerável, o que lhe coube participação na região do MATOPIBA. Nos estados de Roraima e Amapá a produção é incipiente, todavia, como também se verificou no Pará e Tocantins, há um campo de conflitos territoriais que atingem camponeses, quilombolas e povos indígenas.

No estado de Rondônia a soja se territorializou na região sul (ou "cone-sul"), favorecida pela oferta de terras com razoáveis preços, estrutura fundiária concentrada e logística da hidrovia do Rio Madeira. A expansão das fronteiras internas de Rondônia deve ser compreendida pelo nexo soja, boi, madeira e terras públicas. A regionalização da soja no sul rondoniense deslocou a pecuária para outras sub-regiões, fazendo da pecuária a principal mercadoria (carne e leite) do espaço agrário. Neste caso, analisamos a expansão da fronteira na sub-região Norte rondoniense, onde o município de Porto Velho, que não tinha "vocação” à agropecuária, passou à posição de primeiro lugar no ranking da pecuária. Assim, um dos efeitos espaciais do agronegócio da soja foi o deslocamento da pecuária para regiões de floresta.

Conclui-se que o agronegócio da soja tem uma centralidade geográfica, designada na crescente demanda por terras, o que faz mover as fronteiras econômicas no Brasil. Contudo, a pressão em novas áreas agrícolas se reveste em demanda territorial, que tende a pressionar o "estoque" de terras que está sob a gestão do Estado, sejam elas áreas protegidas/institucionais (Unidades de Conservação, Terras Indígenas e Quilombolas) ou as chamadas terras devolutas. A geografia da soja tensiona a gestão das áreas públicas, pressionando as áreas protegidas e os territórios tradicionais para expandir a fronteira do agronegócio na Amazônia.

\section{Agradecimentos}

Conforme indicado no início deste trabalho construído a partir de pesquisas que vem sendo realizadas desde o ano de 2015 , cujo o objeto de estudo esteve - e está vinculado - a projetos de iniciação científica e pós-graduação. Entre as principais agências financiadoras estão: o Conselho Nacional de Desenvolvimento Científico e Tecnológico - CNPq, 


\section{A caminho do Norte: cartografia dos impactos territoriais do agronegócio em Rondônia [Amazônia Dcidental]}

e a Fundação Rondônia de Amparo ao Desenvolvimento das Ações Científicas e Tecnológicas e à Pesquisa do estado de Rondônia - Fapero.

Por meio da concessão de bolsas de iniciação científica, foram concluídos cinco ciclos do Programa Institucional de Bolsas de Iniciação Científica (Pibic). Trabalhados dos quais resultaram em artigos científicos, e reconhecidos com menções honrosas em três dos cinco ciclos concluídos.

Com o apoio dos recursos da Fapero foram realizados trabalhos de campos, participação em eventos regionais e nacional, assim como na organização de eventos de cunho científico-acadêmico que, possibilitaram a ampliação da discussão dos estudos geográficos da/na Amazônia relacionadas as dinâmicas socioterritoriais e ambientais vinculadas a expansão da fronteira agrícola.

Ambas as pesquisas buscam explicar os questionamentos relacionados as divergências entre agentes e sujeitos territorializados na Amazônia, com destaque para o estado de Rondônia, visto que a partir desta compreensão, intenta-se que tais estudos possam contribuir com a revisão e formulação de políticas públicas voltadas ao espaço agrário rondoniense e que possam servir como norteadores para demais aplicações políticas no território amazônico.

Não poderíamos deixar de incluir em nossos agradecimentos, a Universidade Federal de Rondônia, por meio do Departamento de Geografia e do Programa de Pós-Graduação em Mestrado e Doutorado em Geografia, visto que ambos disponibilizaram toda a estrutura física e intelectual, por meio de seu quadro de docentes comprometidos com a educação/ensino superior, assim como com a pesquisa e extensão em tal intensidade de importância.

\section{REFERÊNCIAS}

ALVES, V. E. L. (org.). Modernização e regionalização nos cerrados do Centro-Norte do Brasil. 1. ed. Rio de Janeiro: Consequência Editora, 2015. ARCHELA, R. S; THÉRY, H. Orientação metodológica para construção e leitura de mapas temáticos. Confins (Paris), p. 3483, 2008. Disponível em: https://journals.openedition.org/confins/3483.

ARROYO, M. Território Brasileiro e Mercado Externo: uma leitura dessa relação na virada do Século XX. In: Souza, Maria Adélia (Org.). Território Brasileiro: usos e abusos. Campinas: Edições Territorial, 2003. 


\section{Geografias de Rondônia Território, Fronteira e Educação}

AUGUSTO, R. DE C. “Carbono Verde: Comércio Negro". Relatório da ONU afirma que a extração ilegal de madeira tem até hackers envolvidos. Ambientalista em Rede. 2012 Disponível em: https:// ambientalistasemrede.wordpress.com/2012/10/17/carbonoverde-comercio-negro-relatorio-da-onu-afirma-que-a-extracao-ilegal-de-madeira-temate-hackers-envolvidos/. Acesso em: 19 out. 2018.

BECKER, B. A Geopolítica na virada do milênio: logística e desenvolvimento sustentável. In: Castro, I.; Gomes, P.; Correa, R. (Orgs). Geografia: conceitos e temas. Rio de Janeiro: Bertrand Brasil, 1995. p. 271-307.

BRANCALION, P. H. S. et al. Fake legal logging in the Brazilian Amazon. Science Advances. Vol. 4, n. 8, 2018. Disponível em: http:// advances.sciencemag.org/content/4/8/eaat1192/tab-pdf.

CIMI. Conselho Indigenista Missionário. «Grileiros intensificam invasão na Terra Indígena Karipuna, em Rondônia». Reportagem do Greenpeace Brasil publicada em 24/01/2019. Acesso: https://cimi.org.br/2019/01/grileiros-intensificam-invasao-na-terra-indigena-karipuna-em-RONDÔNIA/.

COSTA SILVA, R. G. A regionalização do agronegócio da soja em Rondônia. Geousp: espaço e tempo, v. 18, p. 298-312, 2014. DOI: https://doi.org/10.11606/issn.2179-0892.Geousp.2014.84534.

COSTA SILVA, R. G. Agentes, procesos y conflictos en la gestión territorial en el estado de Rondônia (Brasil). Polis, Santiago, v. 15, n. 45, p. 319-344, dic. 2016. Disponível em: http://dx.doi.org/10.4067/ S0718-65682016000300016.

COSTA SILVA, R. G. Amazônia globalizada: da fronteira agrícola ao território do agronegócio - o exemplo de Rondônia. Confins (Paris), v. 23, p. 1-30, 2015. Disponível em: http://confins.revues.org/9949.

COSTA SILVA, R. G. Avanços dos espaços da globalização: a produção de soja em Rondônia. Dissertação (Mestrado em Desenvolvimento Regional e Meio Ambiente) - Universidade Federal de Rondônia, Porto Velho, 2005.

COSTA SILVA, R. G. Das margens do Madeira ao interior da floresta: percursos da formação socioespacial de Rondônia (1970-1995). In: Almeida Silva, A; Nascimento Silva, M. G. S; Costa Silva, R. G. (Orgs.) Colonização, território e meio ambiente em Rondônia: reflexões geográficas. Curitiba: Editora SK, 2012. v. 1, p. 58-82.

COSTA SILVA, R. G. Espaço, sociedade e natureza em Rondônia. Revista Geoamazônia, v. 1, p. 144-165, 2014. Disponível em: http://dx. doi.org/10.17551/2358-1778/geoamazonia.n2v1p144-165. 


\section{A caminho do Norte: cartografia dos impactos territoriais do agronegócio em Rondônia [Amazônia Dcidental]}

COSTA SILVA, R. G.; MICHALSKI, A; LIMA, L. A. P.; CONCEIÇÃO, F. S. Geografia das dinâmicas territoriais agrárias de Rondônia. In: Ferreira, Gustavo Henrique Cepolini. (Org.). Geografia agrária em debate: das lutas históricas às práticas agroecológicas. Jundiaí: Paco Editorial, 2017, v. 1, p. $143-162$.

COSTA SILVA, R. G; CONCEIÇÃO, F. S. Agronegócio e campesinato na Amazônia brasileira: transformações geográficas em duas regiões nos estados de Rondônia e Pará. Geographia (UFF), v. 19, p. 54-72, 2017. Disponível em: www.geographia.uff.br/index.php/geographia/article/ view/1008.

COSTA SILVA, R. G; SILVA, V. V; LIMA, L. A. P. Os novos eixos da fronteira na Amazônia ocidental. Confins (Paris), v. 43, p. 1-6, 2019. Disponível em: https://journals.openedition.org/confins/24950.

COSTA, S. M. G. Sojicultura e mercado de terras na Amazônia. Universidade Federal do Pará (UFPA). R. Pol. Públ., São Luís, v. 19, n. 1, p. 173-185, jan./jun. 2015. DOI: http://dx.doi.org/10.18764/21782865.v19n1p173-185.

COY, M. Rondônia: frente pioneira e programa Polonoroeste. O processo de diferenciação sócio-econômica na periferia e os limites do planejamento público. Tübinger Geographische Studien, n. 95, p. 253-270, 1987.

GRAZIANO DA SILVA, J. G. A modernização dolorosa: estrutura agrária, fronteira agrícola e trabalhadores rurais no Brasil. Rio de Janeiro: Zahar, 1982.

HUERTAS, D. M. O papel de Porto Velho como nodal do transporte rodoviário de carga. In: Costa Silva (org.). Porto Velho, urbanização e desafios para uma cidade centenária. Porto Velho: Temática Editora/ Edufro, 2018. p. 127-144. Disponível em: www.gtga.unir.br/pagina/ exibir/9501.

MARTINELLI, M. Cartografia dinâmica: tempo e espaço nos mapas. Geousp - espaço e tempo (online), (18), 53-66, 2005. https://doi. org/10.11606/issn.2179-0892.Geousp.2005.73972

MARTINS, J. S. Fronteira: a degradação do outro nos confins do humano. São Paulo: Hucitec, 1997.

MELLO-THÉRY, N. A. de. Território e gestão na Amazônia: terras públicas e os dilemas do Estado. São Paulo: Annablume, 2011.

MICHALSKI, Amanda. Geografia da pecuária e do desmatamento em Porto Velho: União Bandeirantes e Rio Pardo. Porto Velho, 2018. 


\section{Geografias de Rondônia Território, Fronteira e Educação}

102f. Trabalho de Conclusão de Curso (Bacharelado em Geografia) pela Universidade Federal de Rondônia - UNIR.

PNUMA. United Nations Environment Programme. Keeping Track of Our Changing Environment: From Rio to Rio+20 (1992-2012), Nairobi. October 2011 ISBN: 978-92-807-3190-3. Disponível em: https:/cetesb.sp.gov.br/proclima/wp-content/uploads/sites/36/2014/05/ Keeping_Track.pdf.

RIBEIRO, A. F. A.; COSTA SILVA, R. G; CORREA, S. S. Geografia da soja em Rondônia: monopolização do território, regionalização e conflitos territoriais. Campo-Território, v. 10, p. 180-201, 2015. Disponível em: www. seer.ufu.br/index.php/campoterritorio/article/viewFile/28439/17010.

RICARTE, Carlos Alberto de Almeida. A psicosfera do espaço agrário de Vilhena: contradições entre o agronegócio e o campesinato. 2017. 167f. Dissertação (Mestrado) - Programa de Pós-Graduação em Geografia, Fundação Universidade Federal de Rondônia, Porto Velho, 2017. Disponível em: www.ri.unir.br/jspui/handle/123456789/2193.

RONDÔNIA. Governo de Rondônia. Secretaria de Estado do Desenvolvimento Ambiental. 21 anos de Zoneamento Socioeconômico e Ecológico do Estado de Rondônia: planejamento para o desenvolvimento sustentável e proteção ambiental. Sedam, Porto Velho, 2010.

SANTANA, R. S; SILVA, S. C. P. G. Avaliação do avanço do desmatamento na Reserva Estadual Extrativista Jaci-Paraná-RO, no período de 1996 a 2016. Terr@Plural, Ponta Grossa, v. 13, n. 1, p. 93-105, jan./ abr. 2019. Disponível em: www.revistas2.uepg.br/index.php/tp/article/ view/10469/pdf.

Santos, M. A natureza do espaço: técnica e tempo, razão e emoção. São Paulo: Hucitec, 1996.

SANTOS, M. Por uma outra globalização: do pensamento único à consciência universal. Rio de Janeiro: Record, 2000.

Théry, H. A dimensão temporal na modelização gráfica. Geousp, São Paulo, v. 17, p. 171-184, 2005. Disponível em: www.geografia.fflch.usp. br/publicacoes/Geousp/Geousp17/Intercambio1_Herv\%C3\%A9.pdf

THÉRY, H. Rondônia: mutações de um território federal na Amazônia brasileira. Curitiba: SK Editores, [1976] 2012.

VALVERDE, O. (coord.). A organização do espaço na faixa da Transamazônica. Vol. 1: Sudoeste amazônico. Rondônia e regiões vizinhas. Rio de Janeiro: IBGE, 1979. 258 p. 


\section{Agroecologia Política e Movimentos Sociais NA AMazônia ${ }^{1}$}

Lucas Ramos de Matos*

\section{INTRODUÇ̃̃o}

A luta pela terra representa o cerne da questão agrária no Brasil e nos remete as teses que vão além da conquista da propriedade. O pressionamento pelo acesso à terra e as condições contemporâneas geraram importantes movimentos sociais como a Via Campesina, com articulação de camponesas e camponeses de 182 organizações enraizadas em mais de 80 países de todos os continentes e o MST (Movimento dos Trabalhadores Rurais Sem Terra), que é formado por milhares de famílias na luta pela terra ou nos/pelos territórios já consolidados. O MST é uma matriz de pensamento e ação popular herdeira do levante dos primeiros povos indígenas, quilombolas e, sobretudo, das Ligas Camponesas que surgiram na contramão da dominação/exploração (política, econômica e militar) nas fazes mercantil, coronelista e militar. Oficialmente, o MST surgiu em 1984, com os objetivos de lutar pela terra, pela reforma agrária e por mudanças sociais. Hoje, o lema "Lutar! Construir reforma agrária popular!" afirma a preocupação do movimento com as questões das populações do campo e da cidade no contexto do avanço da retórica neoliberal autoritária como movimento globalizado. O entendimento do MST é de que o adjetivo popular sintetiza os desafios e o papel do movimento social na luta pela terra, nos territórios já conquistados, por justiça ambiental e soberania alimentar, contra a privatização daquilo que é público (sobretudo os recursos natu-

\footnotetext{
${ }^{1} \mathrm{O}$ texto é resultado parcial da pesquisa de mestrado em geografia, sob a orientação do professor Ricardo Gilson da Costa Silva, do Programa de Pós-graduação em Geografia da Universidade Federal de Rondônia (PPGG/UNIR).

" https://orcid.org/0000-0002-8732-1063
} 


\section{Geografias de Rondônia Território, Fronteira e Educação}

rais, ambientais e genéticos), formando uma agenda para o meio rural e urbano que corresponde ao novo período histórico de hegemonia do sistema mundo moderno-colonial-patriarcal em forma de agribusiness - versão da agricultura tecnicista-desenvolvimentista norte-americana também chamada de agronegócio.

$\mathrm{Na}$ Amazônia brasileira, marcada majoritariamente pelas narrativas dos grupos hegemônicos, a trajetória da pistolagem e da grilagem, quase sempre praticadas por agentes públicos e econômicos, silenciada nas diversas instâncias política e jurídica, fez/faz com que as agromilícias e grileiros de terras públicas ampliassem de forma gradual suas "cotas de poder $^{2}$ ", beneficiando diretamente grupos econômicos ligados ao agro. Por outro lado, as/os sem-terra, sob uma série de ofensivas neoliberais que vão dos estigmas e preconceitos à violência concreta do Estado e do latifúndio, formam um feixe de conceitos (como território, sobriedade, soberania alimentar, biopoder etc.) e pautas locais que se manifestam na luta pela/ na terra, pelo/nos territórios e pela/na natureza, por representação política, entre outras pautas, formando a racionalidade ambiental dos movimentos sociais contemporâneos de luta pela terra e por/no território.

A partir da perspectiva da conquista da terra, os assentamentos se constituem em uma dinâmica de coletividade que está relacionada a uma visão globalizada de transformação da sociedade, com um novo direcionamento que procura, entre outros, a soberania alimentar dos povos e a sustentabilidade da vida por meio (não somente) de uma ética/ relação biocêntrica e ecocêntrica ${ }^{3}$ de natureza, que também está expressa

\footnotetext{
${ }^{2}$ Termo cunhado inicialmente pelo antropólogo Pal Elliott Little em sua "etnografia dos conflitos socioambientais", para tratar os conflitos sociais que giram no entrono dos recursos naturais (terra, água, madeira, minério etc.). O termo cotas de poder tem sido reciclado em nossas investigações na temática dos conflitos socioambientais e refere-se ao conjunto de recursos que determinado agente ou grupo possui a ser investido na arena de embates, que envolve patrimônios, status social, acesso político e jurídico, construção de narrativas, etc. As cotas de poder põem em desvantagem os grupos sociais que possuem menos recursos para investir em suas causas.

${ }^{3}$ A noção de ética/relação ou princípio biocêntrico foi cunhada inicialmente pelo antropólogo Rolando Toro ao sugerir o modelo teórico da Biodança. Além de Toro, Humberto Maturana, Francisco Varela, Eduardo Gudynas, entre outros, são importantes contribuintes do tema. $\mathrm{O}$ biocentrismo e o ecocentrismo sugerem um ambiente em que o homem aparece não como administrador, mas como parte integrante dos ecossistemas e tem a natureza como um sujeito de direitos (Gudynas, 2009; 2010). Trata-se da conexão com os ciclos naturais que garante a evolução da vida como um todo. Para além disso, o biocentrismo e o ecocentrismo marca uma ruptura com a noção antropocêntrica em que
} 


\section{Agroecologia Política e Movimentos Sociais na Amazônia}

nos territórios material e imaterial do MST. O território material é onde o MST projeta suas ações, por meio de agentes locais, no diálogo e no pleiteio de benfeitorias e políticas públicas com outros agentes, visando à organicidade dos modos de produção nos assentamentos conquistados. O território imaterial, por sua vez, está na mística do MST (Coelho, 2014; Moscal, 2017). É onde as camponesas e camponeses manifestam o sincretismo de suas cosmovisões de mundo, seus valores culturais e simbólicos, que têm, entre outras coisas, a natureza como um bem comum que transcende a visão de natureza como mercadoria do mundo coisificado, fragmentado, hegemônico e desigual. Neste sentido, temos argumentado que os movimentos sociais contemporâneos têm protagonizado um processo de territorialização de uma racionalidade ambiental, amparada na reapropriação social da natureza e reinvenção dos territórios (Leff, 2006; 2009; Porto-Gonçalves, 2012; 2016), que se mostra como alternativa de enfrentamento da crise ambiental.

Através de uma abordagem amparada na ecologia política (Vayda, 1983; Porto-Gonçalves, 2005; 2012; 2016; Martínez-Alier, 2018; Leff, 2006; 2009; 2015) tentaremos “explorar” a ecologização das lutas sociais na Amazônia, demonstrando que a apropriação da ecologia pelos movimentos sociais contemporâneos tem respaldo no processo de reapropriação social da natureza e reinvenção dos territórios (Leff, 2006; 2009; Porto-Gonçalves, 2012; 2016). Nesta importante categoria do campesinato Amazônico, há uma diferenciação das vertentes ecológicas e representações sociais de ambiente, localmente amparadas por uma ética/relação biocêntrica e ecocêntrica de natureza, que se expressa na racionalidade ambiental dos movimentos sociais contemporâneos, que ao se apropriar, respeita as manifestações de vida material e simbólica na natureza, resultando em um ecologismo que envolve pautas locais e concretas contra a degradação ambiental e humana e dos ecossistemas locais, o uso dos agrotóxicos e o racismo ambiental às comunidades; de justiça ambiental; de resistência à invasão dos territórios comunitários e o roubo de terras públicas; no afeto pela terra e nas coletividades humanas, na reivindicação dos territórios; pela reapropriação social da natureza. Estas pautas também estão arraigadas nas categorias esquecidas pela racionalidade econômica dos modelos interpretativos dominantes; na ecologia da alma, do espírito e das subjetividades humanas (Marques, 2012; 2016).

a natureza está para o domínio do homem. Tanto o biocentrismo quanto o ecocentrismo tem como principal premissa a sustentabilidade da vida. 


\section{Geografias de Rondônia Território, Fronteira e Educação}

Na questão metodológica, optamos por uma combinação $a d$ hoc de métodos (técnicas) quantitativos, seguidos de métodos (técnicas) qualitativos, sendo uma adaptação do método de "contextualização progressiva" (Vayda, 1983), que por sua vez, estabelece contextos progressivamente mais amplos ou densos da pesquisa para analisar relações/ interações homem-natureza, a partir de racionalidades e conhecimentos de contextos, no sentido de sistematizar elementos inusitados do estudo, à medida que o pesquisador, para entender as forças que contribuem para o fenômeno, partindo primeiramente da formulação de questões mais amplas, posiciona-se em locais, atividades e ocasiões específicas, optando pela combinação de métodos (técnicas) quantitativos, seguidos de métodos (técnicas) qualitativos, assumindo o papel fundamental de inserir tais ocasiões locais e específicas dentro de um complexo de causas e efeitos. Esta abordagem está ancorada ao campo teórico-político da ecologia política e se ocupa em reforçar o diálogo entre Ciências Sociais e Ciências Naturais, no sentido de produzir "uma ciência verdadeiramente ecológica", que focaliza o relacionamento dinâmico entre o biofísico e o social, que por sua vez, requer mudanças na prática científica.

Nesse sentido, aproveitamos esta abordagem de imersão em territórios do MST de Rondônia, optando pela adoção de abordagens quantitativas, seguidas de abordagens qualitativas. A abordagem quantitativa envolveu o posicionamento nos assentamentos, nas unidades de produção camponesa, nas reuniões, assembleias, encontros, etc. $\mathrm{Na}$ questão qualitativa, optamos pelo diálogo (conversa formal e informal), entrevistas semiestruturadas aliadas à observação participante. É neste sentido que enfatizamos o significado prático de "contextualizar progressivamente", quando optamos por esperar o inesperado.

\section{O PROCESSO DE REAPROPRIAÇÃO SOCIAL DA NATUREZA}

A crise ambiental é uma crise da racionalidade econômica moderna, da razão, do conhecimento; dos modelos interpretativos dominantes, conforme argumenta Leff.

A problemática ambiental emerge como uma crise de civilização: da cultura ocidental; da racionalidade da modernidade; da economia do mundo globalizado. Não é uma catástrofe ecológica nem um simples desequilíbrio da economia. É a própria desarticulação do mundo ao qual conduz a coisificação do ser e 


\section{Agroecologia Política e Movimentos Sociais na Amazônia}

a superexploração da natureza; é a perda do sentido da existência que gera o pensamento racional em sua negação da outridade (Leff, 2006, p. 15).

Frente à crise ambiental, a chamada racionalidade ambiental, por sua vez, sugere uma estratégia teórica que articula condições ideológicas, teóricas, políticas e materiais "que estabelecem novas relações de produção e novas bases para o desenvolvimento das forças produtivas" (Leff, 2009, p. 282). A racionalidade ambiental assume a função de estabelecer novas formas de reinterpretação da natureza que confrontem os paradigmas da racionalidade econômica dominante, através do pensamento/ação ambiental baseado em processos políticos e sociais. A racionalidade ambiental é, portanto, a construção de uma nova ordem ecológica baseada em valores socioculturais entrelaçados em relações de poder, pela reapropriação social da natureza e pela autogestão dos processos produtivos (Leff, 2015) que, por sua vez, confronte a nova ordem governamental ambiental.

Contra isto, surgem os movimentos pela transição ecossocial que questionam a degradação ambiental sobre as camadas sociais marginalizadas e os ecossistemas locais, o racismo ambiental, os megaprojetos desenvolvimentistas e a participação política.

A desconstrução da razão que as forças ecodestrutivas de um mundo insustentável desencadearam e a construção de urna racionalidade ambiental não são apenas um empreendimento filosófico e teórico. Estão arraigadas em práticas sociais e em novos atores políticos. Trata-se, ao mesmo tempo, de um processo de emancipação que implica a descolonização do saber submetido ao domínio do conhecimento globalizante e único, para fertilizar saberes locais (Leff, 2006, p. 18-19).

O processo de reapropriação social da natureza e reinvenção dos territórios se funda na contramão das questões que movem a crise ambiental (Leff, 2006). Para Leff, os movimentos pela reapropriação social da natureza incorporam em suas pautas algumas dessas demandas: 


\section{Geografias de Rondônia Território, Fronteira e Educação}

a) maior participação nos assuntos políticos e económicos e na gestão dos recursos ambientais.

b) inserção nos processos de democratização do poder político e de descentralização econômica.

c) defesa de seus territórios, seus recursos e seu ambiente, além das formas tradicionais de luta pela terra, emprego e salário.

d) elaboração de novos modos de produção, estilos de vida e padrões de consumo afastados dos modelos capitalistas e urbanos globais, transnacionais e estrangeiros.

e) procura de novas formas de organização política, diferentes dos sistemas corporativos e institucionais de poder.

f) organização em torno de valores qualitativos (qualidade de vida), além dos benefícios derivados da oferta do mercado e do Estado benfeitor.

g) crítica à racionalidade económica fundada na lógica do mercado, namaximização do lucro e na eficiência tecnológica, e aos aparelhos de controle económico e coerção política e ideológica do Estado (Leff, 2006, p. 556-557).

Como se vê, os movimentos pela reapropriação social da natureza têm como característica o fato de que possuem pautas que vão de questões locais de resistência, organicidade política e reivindicação de direitos à articulação de pautas transnacionais, como é o caso da Via Campesina (Desmarais, 2013).

Os movimentos sociais contemporâneos têm territorializado uma racionalidade ambiental baseada na construção de novas bases de poder para uma transição societária; em novo léxico teórico-político, na resistência nos territórios comunitários frente à rapinagem capitalista da natureza, que ora amplia cada vez mais, e na construção de forças produtivas de reapropriação social da natureza, dos territórios e do poder; como alternativa de enfrentamento ao ápice da crise ambiental que vai do colapso ecológico, ao risco de falência das democracias supostamente consolidadas. 


\section{Agroecologia Política e Movimentos Sociais na Amazônia}

\section{Agricultura CAMPONESA NAS FRONTEIRAS DO CAPITALISMO}

A agricultura globalizada tem impactado todas as regiões do planeta. $\mathrm{Na}$ Amazônia brasileira, onde se encontram as condições propícias de evolução e diversidade da vida, as manifestações culturais, modos de vidas e adaptabilidade humana nos ecossistemas, tem experimentado um processo assustador de mudanças ambientais e transformações territoriais nos usos múltiplos da terra. Os modos de vida que se manifestam nas vertentes alternativas de agricultura nos territórios comunitários na Amazônia têm sido fragmentados por um modelo de desenvolvimento econômico autoritário, que tem condicionado as coerências territoriais endógenas aos fluxos da globalização neoliberal (Costa Silva, 2010; 2014; 2015).

$\mathrm{Na}$ Amazônia, a localização geográfica das comunidades nos permite entender que a agricultura local está cada vez mais condicionada aos fluxos da globalização neoliberal autoritária. A agricultura capitalista tem impactado até mesmo as regiões mais remotas da Amazônia, antes territorializadas pelas lógicas do campesinato (Costa Silva; Lima; Conceição, 2018).

Para dar um exemplo, muitas dessas comunidades estão aglutinadas a grandes e médias propriedades, que por sua vez, se constituem na força motor da agropecuária (gado de corte), ou produção de grãos (soja e milho), e são impulsionadas por transformações econômicas. Este é o caso de três importantes assentamentos na região central de Rondônia: Margarida Alves, Palmares e Padre Ezequiel, que pode ser verificado de forma sucinta a partir das transformações territoriais que moldam o recorte central do estado de Rondônia ao longo das últimas décadas. Frente aos assentamentos (e outras comunidades indígenas) estão aglutinadas medias e grandes propriedades (resultado do PIC de Ouro Preto) que por sua vez, se constituem na formação da bacia leiteira de Ouro Preto do Oeste, aliado aos investimentos de empresas do ramo alimentício, a exemplo dos grupos JBS-Friboi, Irmão Gonçalves, Italac, Ouro Minas, Monte Verde, Tradição, entre outros, que por sua vez, projeta suas ações na região e nas comunidades locais, fragmentando os modos de produção e reprodução da vida material e simbólica, a diversidade de plantios epráticas alternativas de agricultura, os ecossistemas locais; destrói a natureza e os modos de vida do campesinato amazônico. 


\section{Geografias de Rondônia Território, Fronteira e Educação}

\section{Agroecologia e RESISTÊNCIA CAMPONESA NA AmAZÔNIA}

No Brasil, a agricultura camponesa tem se destacado cada vez mais no contexto de produção agroecológica. Surgiu a partir da ocupação de imigrantes europeus e africanos, tendo como principais premissas o trabalho familiar, o uso de áreas pequenas, a produção para o autoconsumo, o mercado interno e local, a produção diversificada e a produção de alimentos sem o uso intenso de agrotóxicos, representando um modo de produção que garante a soberania alimentar da agricultura camponesa.

A agricultura camponesa representa um modo de ser e de viver que tem centralidade na reprodução social da família, e a sua contradição in terna se dá entre a capacidade de trabalho disponível da família e as necessidades de consumo (Chayanov, 1974), gerando, assim, uma lógica econômica própria, uma especificidade camponesa que permitiu sua longevidade através dos séculos.

A agricultura camponesa tem se destacado como o perfil de produção mais sustentável, através de vertentes agroecológicas (Costa Neto; Canavesi, 2002; Frade; Sauer, 2017; Matos, et al., 2020) e a pluriatividade (Schneider, 2003). Amparada por premissas que diferem o campesinato, a agricultura camponesa se propaga por meio de requisitos, como as vertentes agroecológicas, a gestão ambiental, o uso de áreas pequenas, a adoção de máquinas leves, o abastecimento popular, a mão de obra familiar e o cultivo de sementes naturalmente selecionadas (sementes crioulas) e, sobretudo, do cuidado com aqueles que consomem os produtos oriundos do campesinato. Apesar de desestimulada, impedida e inibida (por questões de ofensiva neoliberal reacionária como acesso à terra, políticas públicas e hegemonia da agricultura capitalista), a agricultura camponesa cresce constantemente, destacando-se pela produção de alimentos saudáveis, cultivados em um modelo que agrega valor e respeito ao ambiente e à humanidade.

Na visão do MST, a agricultura camponesa está em função da sustentabilidade da vida, sendo chave para a garantia da soberania alimentar do povo brasileiro (MST, 2021). Apesar das vantagens, a agricultura camponesa ainda enfrenta grandes dificuldades, pois o avanço do latifúndio se dá sobre o retrocesso do campesinato, por "ser estrangulado", por falta de subsídios e influência política, sendo assim, bloqueado, impedido, reprimido e inibido, enquanto o latifúndio é estimulado, apoiado, financiado, protegido e defendido por grupos hegemônicos. Para dar um exemplo, no Governo Bolsonaro, aprofundando tendências 


\section{Agroecologia Política e Movimentos Sociais na Amazônia}

de governos anteriores (sobretudo após o golpe de 2016) a "reforma agrária" foi totalmente paralisada, enquanto que avança a regulação da grilagem de terras públicas (PL 2633/2020), aliado às múltiplas formas de violências no campo. Outra questão está nas medidas pró agronegócio dos últimos anos. O acesso ao crédito rural, por exemplo, de 2019 a 2020, dos 176 bilhões de reais, 163,2 foram destinados à agricultura capitalista, enquanto que 22,8 foram destinados à agricultura camponesa (Alentejano, 2020).

É de longa data que as vertentes agroecológicas vêm sendo discutidas no MST, junto às camponesas e camponeses. Estes que atuam no sentido de preservar a vida, e, consequentemente, têm cuidado do ambiente. Quando as famílias lutam por terra, moradia, escola, energia, água, sementes, crédito agrícola, entre outros, estas pautas constituem-se também em luta a favor do meio ambiente. A terra, aliás, é um bem sagrado, como assim diz o senhor Luiz - em nosso trabalho de campo realizado em 2019 no PA Margarida Alves (em Nova União, região central de Rondônia) - sobre seu apego a sua pequena propriedade de quatro hectares: "é que aqui nós somos igual minhoca (...) nós gostamos é da terra". É o que traz também os aspectos culturais e simbólicos da luta social do Movimento, por exemplo, quando em poesia, descreve o ciclo de produção e reprodução da vida material e simbólica que a terra é capaz de gerar: "A chuva cai sobre a natureza, a planta cresce gerando a riqueza, e o trabalhador luta com certeza, pra não faltar o pão sobre a nossa mesa. A terra guarda a raiz da planta que gera o pão, a madeira que dá o cabo da enxada e do violão" (Oficina de músicos do MST), ou quando narra o modelo de desenvolvimento defendido pelas camponesas e camponeses do MST, frente aos impérios alimentares do capital moderno-colonial, onde a democratização da terra é um importante caminho para a transformação na sociedade: "Queremos que abrace esta terra por ela quem sente paixão, quem põe com carinho a semente pra alimentar a Nação. A ordem é ninguém passar fome, Progresso é o povo feliz, A Reforma Agrária é a volta do agricultor à raiz" (Oficina de músicos do MST). O camponês, pesquisador e poeta Ademar Bogo também traz o foco das estratégias de luta pela terra e na terra, e a organização do trabalho no MST, cuja terra ampara o modelo produtivo do movimento como contraposição ao modelo capitalista em forma de agronegócio: "Quando chegar na terra, Lembre que ainda não tem liberdade, Este é o primeiro passo que estamos dando nesta sociedade, Só a terra não liberta, Este é o alerta, Aumenta a ansiedade Isto virá no dia que com ousadia ganhar a cidade" (Oficina de músicos do MST). Se por 


\section{Geografias de Rondônia Território, Fronteira e Educação}

um lado o discurso neoliberal tem feito uma disputa pelo imaginário humano como um território a ser conquistado/disputado dentro da luta paradigmática, por outro lado, a mística é o território imaterial onde o Movimento demonstra seu projeto de construção social e cultural de sociedade.

Figura 1 - Mística camponesa e movimentos sociais na Amazônia.

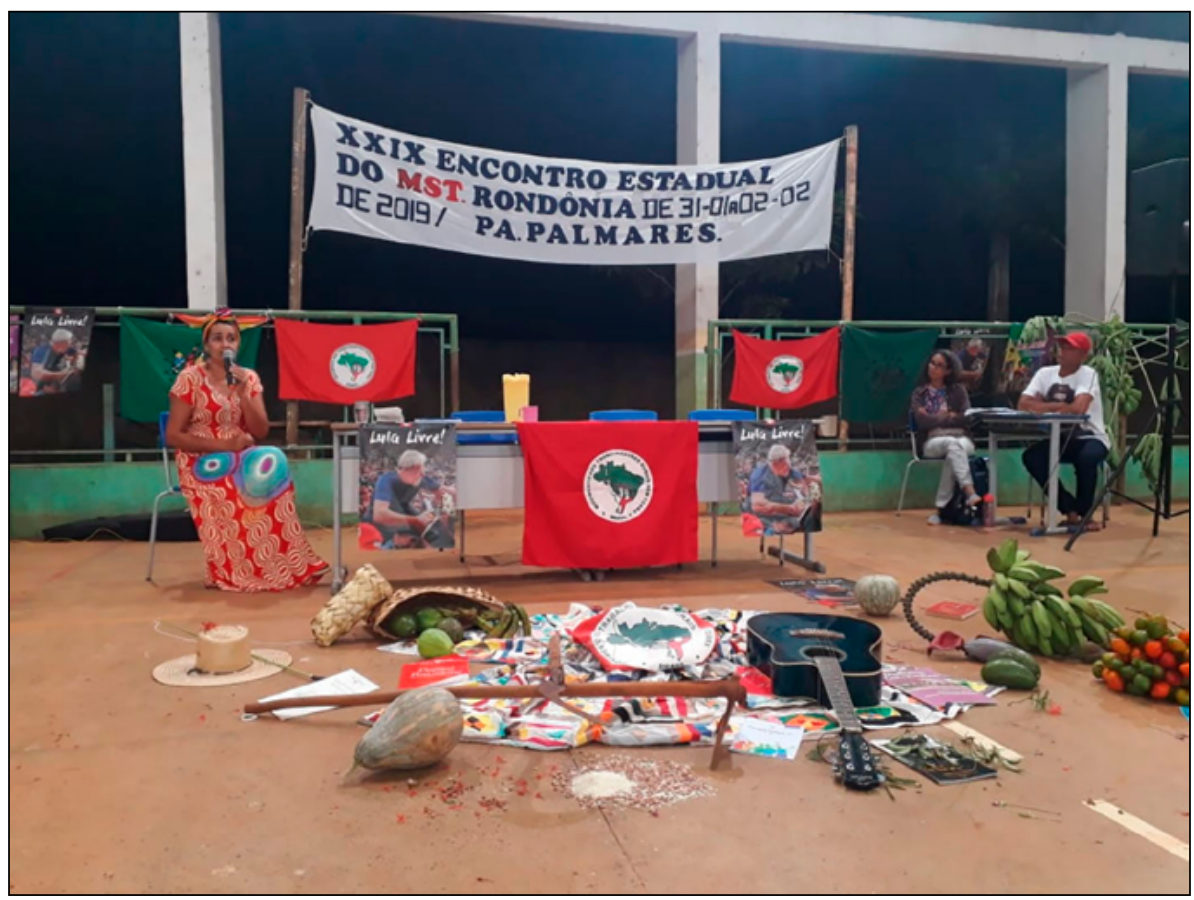

Fonte: Matos, 2021.

Porto-Gonçalves (2005, p. 28) traz a territorialidade das camponesas e camponeses do MST como populações "detentoras de um acervo de conhecimento diversificado, um dos mais ricos patrimônios da humanidade, e habitam os maiores acervos de biodiversidade".

Uma nova configuração da questão agrária está em curso e novas questões têm se apresentado ao debate, como é o caso dos organismos laboratorialmente modificados. 
Trata-se de um tema estratégico para todos os envolvidos nas lutas emancipatórias, sobretudo no campo. Afinal, este tema não pode ser resumido ao debate acerca da poluição do ambiente,em si mesmo importante. É um tema rigorosamente vital para todos os que se colocam numa perspectiva emancipatória e, assim, é muito mais do que um tema controvertido. O envolvimento do MST e da Via Campesina nesse tema torna-os estratégico, e não só para si mesmos, mas para toda a humanidade. A natureza volta a adquirir centralidade no debate do devir histórico e, com isso, traz para o centro da cena uma série de sujeitos sociais que acreditávamos estarem fadados à extinção e que emergem dos campos, dos cerrados, das florestas, dos mangues e dos povos que teceram suas matrizes de racionalidade com esses ambientes. Aliás, essas populações são hoje detentoras de um acervo de conhecimento diversificado, um dos mais ricos patrimônios da humanidade, e habitam os maiores acervos de biodiversidade, posto que são áreas que ficaram a salvo das monoculturas e sua pobre diversidade genética típicas da agricultura capitalista. Assim, a questão agrária não só se urbaniza como se mundializa e, assim, faz sentido uma internacional camponesa, como a Via Campesina, da qual o MST é um dos principais protagonistas. Há, assim, uma linha que aproxima tanto a Monsanto ao McDonald como, contraditoriamente, os agricultores franceses ao MST, aos camponeses e indígenas hondurenhos, aos zapatistas, aos cocaleros, aos mapuche, aos indigenatos equatorianos, mexicanos, aos piqueteros, aos sem-tetos (Porto-Gonçalves, 2005, p. 28).

Esse diálogo horizontal é o que se vê na relação das populações sem terras com a natureza, que transcende a simples forma materialista de resistência quando o discurso neoliberal tenta impor sua hegemonia na relação capital nacional-globalizado, onde as camponesas e camponeses demonstram (não somente), seja através do bojo da insatisfação com a degradação ambiental, da preocupação com os que consomem seus produtos, ou simplesmente no apego à terra e aos múltiplos usos e significados que ela possui; estes que respeitam a presença de outros seres (até mesmo os imaginários) e considera a diversidade 


\section{Geografias de Rondônia Território, Fronteira e Educação}

da vida, constituindo sua ecologia com rico acervo de biodiversidade, em sintonia com a presença humana, típico da agricultura camponesa.

Como forma de investimento nas coletividades humanas e construção de movimentos alternativos, o Movimento investe na criação de cooperativas e associações, que reúne famílias assentadas entorno de projetos, ideias, conceitos e modos de produção coletivos. O cooperativismo nos assentamentos do MST pode ser entendido como uma alternativa de concretizar a proposta de organicidade do território, onde o movimento tem demonstrado a sua importância social no contexto da produção de alimentos saudáveis e diversificados para as populações das cidades. Para o MST, a cooperação faz parte de um processo pedagógico que permite que as famílias rompam com o individualismo e passem a acreditar na ação da força conjunta da produção, por meio da divisão social do trabalho e da conquista de políticas públicas. O cooperativismo camponês é, também, uma forma de coletividade e solidariedade humana que contempla a aceitação da outridade ${ }^{4}$. A cooperação transcende as questões burocráticas e institucionais desde as pautas de resistências locais e concretas nos acampamentos aos assentamentos conquistados, à participação nos espaços comunitários de trabalho, festas, reuniões, assembleias encontros de jovens, etc. Uma dessas formas de cooperação não institucionalizada é o mutirão, prática muito comum nos assentamentos. Geralmente, os mutirões são organizados para a construção de escolas, igrejas, para o roçado, ou até mesmo para a construção de uma ponte quando a gestão pública local não cumpre suas obrigações. Nos assentamentos, os mutirões acontecem, geralmente, quando um assentado ou assentada passam por enfermidade e ficam impossibilitados de cumprir suas atividades laborais. Além de demonstrar a solidariedade humana de camponesas e camponeses, para o MST, essas são formas primárias de cooperação, pois as principais formas de cooperação estão voltadas para a organização na produção, para o acesso ao crédito, e na comercialização dos produtos.

\footnotetext{
${ }^{4}$ Conceito fundamental da obra de Enrique Leff, extraído a partir da noção de alteridade, cunhada por Emmanuel Levinas. A ética da outridade vai ao desencontro com a negação do Outro e nos convida a viver com a diferença. É um convite ao encontro com o Outro. Dessa forma, a outridade pressupõe o direito à diferença: é o caminho em que se constrói a política da diferença, o diálogo de saberes, a racionalidade ambiental; os caminhos para a sustentabilidade da vida (Leff, 2006).
} 


\section{Agroecologia Política e Movimentos Sociais na Amazônia}

Os motivos para cooperar possuem razões econômicas, que vão do incremento da renda, obtenção de crédito, aumento da produtividade e desenvolvimento das agroindústrias familiares. As razões sociais e políticas envolvem o acesso à moradia digna e infraestrutura nos assentamentos, e participação nas lutas vinculadas às necessidades específicas e imediatas na realidade local. Existem também as razões ambientais, que estão na preocupação com a produção de alimentos saudáveis para a sociedade. As famílias aprendem, divulgam e articulam ideias para preservar o meio ambiente, produzindo alimentos saudáveis, evitando o uso de monoculturas e agrotóxicos.

O campesinato do MST é composto por jovens, crianças, homens e mulheres camponesas e camponeses, os quais formam os territórios material e imaterial do MST. Além da democratização da terra que massacra os menos favorecidos em um crime que "comemora" cinco séculos, silenciado nas diversas instâncias da sociedade, aqueles que compõem o MST apostam na preservação ambiental através de boas práticas, as quais têm na agroecologia uma base de formação ecológica, social, política e cultural, no sentido da emancipação humana, destacada na figura de homens, mulheres, das crianças sem-terrinhas e da juventude que lutam pelo acesso à terra para as famílias que estão na condição desumana de sem-terra, embaixo da lona preta, recuperando a autonomia por meio da educação no campo e das escolas do campo, por justiça ambiental, por uma sociedade intercultural baseada na política da alteridade, pelo fortalecimento da cultura popular camponesa, pelas religiosidades e a mística (que demonstra formas também não materialistas de oposição ao capital moderno-colonial patriarcal), pelas mulheres do campo e da cidade e seus direitos historicamente negados, pelos coletivos LGBTQIA+ e mulheres sem-terra (demostrando as múltiplas e simultâneas opressões do patriarcado e, atualmente, a oposição à ideologia sexista dominante e à misoginia) do campo e da cidade, por uma agricultura sustentável, por um mundo sem exploração humana; pela sustentabilidade da vida no planeta Terra.

Já é sabido que a construção de uma identidade coletiva é facilitada quando existe um contramodelo. A maneira como as camponesas e camponeses constroem seus territórios materiais e imateriais nos espaços onde vivem mostra que é possível ampliar o formato de produzir, mesmo dentro das dependências do discurso político, da ideologia do processo econômico, das hegemonias localmente impostas. As reivindicações do MST sempre defendem uma agricultura sustentável, baseada na matriz tecnológica dos agroecossistemas. As vertentes ecológicas se caracte- 


\section{Geografias de Rondônia Território, Fronteira e Educação}

rizam como alternativa de estímulo à incorporação de boas ações das camponesas e camponeses agroecológicos nos assentamentos do MST, tendo em vista que a agroecologia, que é o tema ecológico central nos territórios do MST, deve ser interpretada de maneira holística, pressupondo o manejoecológico dos recursos ambientais e se configurando na matriz sociocultural latino-americano, que se empenha em desmistificar o ódio contra estes que lutam pela democratização da terra e pela soberania alimentar dos povos; tal ódio que assume formas de dominação histórica, legitimada por um discurso neoliberal de desenvolvimento considerado político e científico (Guzmán; Molina, 2013), que tem nos impedido de compreender e reverter nossa própria realidade.

É de vital importância que o estímulo às boas práticas, se configurando também a partir de uma visão holística e na ecologia de saberes, seja incorporadoem um processo de transição agroecológica que desconsidere o preconceito que se tem com os modos de vida do campesinato, uma vez que esta deve ter o caráter de promover a formação inicial, qualificada e contínua das famílias na gestão ambiental de seus territórios, suas identidades e seus saberes populares e cosmologias que pautam a produção da vida material e simbólica do cotidiano,e o diálogo de saberes (Leff, 2015), à luz de racionalidades híbridas para um pensamento alternativo que possibilite uma ruptura com modelos interpretativos baseados unicamente no pensamento hegemônico das ciências duras (Floriani, 2013), na imposição cultural do mundo cristão ocidental e a diferença política do colonialismo e do capitalismo em sua atual fórmula moderno-colonial patriarcal, que tem na consolidação da racionalidade econômica a imposição necessária de um "desenvolvimento sustentável” baseado nas atuais formas de dominação/exploração. A agroecologia desenvolvida nos assentamentos, por sua vez, baseia-se na produção em agroecossistemas diversos, sendo que o objetivo é promover o equilíbrio entre plantas, solos, nutrientes, luz solar, água e outros elementos coexistentes.

A agroecologia engloba orientações que vão desde o controle de pragas, aumento de resiliência à correção de doenças ou problemas do solo. Os resultados dos ecossistemas de base agroecológica se despontam na disponibilidade de cobertura vegetal para a proteção do solo, produção constante de alimentos saudáveis sem grande variedade, conservação dos recursos hídricos pela disponibilidade vegetativa e cobertura, manejo adequado dos recursos produtivos, reciclagem de nutrientes e produção de biomassa, controle biológico de pragas e garantia de produção sem o uso de insumos químicos que possam degradar o 


\section{Agroecologia Política e Movimentos Sociais na Amazônia}

ambiente (Altieri, 2004). Esse é o caso das camponesas e camponeses do assentamento Margarida Alves expressos nas mais variadas especificidades, como representação de uma agricultura biodinâmica e em fluxos de energia (Kohler; Negrão, 2018), mesmo quando as grades da racionalidade dominante impõem suas hegemonias, e às vezes os prendem, como traz o estudo de Kohler e Negrão (2018), em uma análise centrada no ecodiscurso, mostrando que essas especificidades, no caso do assentamento Margarida Alves, demonstram que são também pautadas na construção de formas quase sempre não materialistas de enfrentamento ao discurso neoliberal, reforçando o que temos argumentado.

The eco-centered discourse of Margarida Alves' leaders and homeopathy/ agroecology practitioners shows a strong convergence, not only with pea- sant's world protest, but also with natives and traditional populations' movements. This moral and ethical discourse is structured as an antithesis to agribusiness' logic, by rejecting the hegemonic "common sense" and crea ting a new terminology (Kohler; Negrão, 2018, p. 15).

É possível perceber que há mais do que um discurso ecocentrado. Há discurso moral e ético que procura renúncia e oposição sistemática à racionalidade econômica, instaurada por meio do "desenvolvimento sustentável” como atual forma de dominação/exploração. Há uma ecologia baseada na resistência agroecológica, que pode ser demostrada por meio das vertentes homeopáticas e agroecológicas, localmente impulsionadas por uma ciência amparada nos saberes populares e espiritualidades, demonstrando uma ecologia baseada tanto em uma ética/relação biocêntrica e ecocêntrica quanto reivindicatória.

Os territórios do MST na Amazônia demonstram que é de vital importância reconhecer que existe outro modelo de agricultura para além da agricultura capitalista praticada por grupos hegemônicos e rapineiros da natureza. $\mathrm{O}$ fato da ocorrência da arborização das pastagens ocorrer de modo empírico, ou até mesmo plantado, ao acaso ou planejado com técnicas agronômicas, como ocorre nas propriedades, demonstra uma sensibilidade ambiental que se expressa, por exemplo, quando uma assentada ou assentado planta uma espécie frutífera com o objetivo de alimentar, além do gado, outros animais como os macacos e os pássaros, ou quando uma frutífera nativa é deixada ao acaso com intuito de alimentar o gado e 


\section{Geografias de Rondônia Território, Fronteira e Educação}

outros animais. Essa relação demonstra uma diferenciação nas práticas e representações sociais do meio ambiente.

É possível perceber que as camponesas e camponeses incentivam, divulgam e articulam experiências que mostram ser possível ampliar este formato de produzir e de se relacionar com o ambiente, mesmo diante das hegemonias localmente impulsionadas por forças exógenas.

Nossa abordagem mostra que, mesmo posicionados nas fronteiras do capitalismo produtivista-tecnicista-desenvolvimentista, as camponesas e camponeses dos assentamentos ligados ao Movimento Sem Terra dão continuidade aos seus saberes populares e modos de vida como forma de resistência e de lembrar sua existência e importância fundamentais na sociedade, marcadas por um modelo econômico autoritário, afirmando a validez do que já foi defendido há muitos anos pelas próprias camponesas e camponeses, no pensar e nas ações de mérito empírico: "Ocupar, Resistir, Produzir" (1989).

\section{CONSIDERAÇÕES FINAIS}

Desde a "primavera silenciosa" de Rachel Carson (1962), que nos fez acordar para o sentido das flores e para as manifestações da vida material e simbólica silenciadas pela racionalidade econômica dominante, quando traz ao mundo os problemas sociais e ecológicos do uso dos DDT, houve uma necessidade de compreender interações da sociedade com a natureza nas suas complexas dimensões de interdependência para entender o espírito de uma ecologia que, como nos diz o grande ecologista humano brasileiro Juracy Marques, perceba que existe gente nos ecossistemas e que há uma necessidade de estudar suas relações com o meio biofísico. Há uma necessidade de estabelecer condições para um diálogo horizontal de conhecimentos como nos aponta Edgar Morin (1982) em "Ciência com consciência", e esse diálogo chama-se ecologia social. Esta que parte da ideia de que toda experiência social produz e reproduz conhecimento, como bem nos ensina Boaventura de Souza Santos, e que os saberes inferiores, próprios de seres inferiores, crença dos modelos interpretativos dominantes que, além do impacto nas práticas sociais de dominação, através de relações desiguais de saber-poder, demonstrou-se um grande equívoco a ser superado no âmbito dos paradigmas emergentes, como aponta a coerência teórico-política do pensamento de Enrique Leff, quando nos convida para o diálogo de saberes e 
anuncia um processo de reapropriação social da natureza que se ampara em uma nova racionalidade ambiental.

A Via Campesina assume a função de articular internacionalmente esse diálogo horizontal, baseado na economia moral, na solidariedade camponesa, na pressão por reforma agrária, na sustentabilidade da agricultura camponesa, na proteção da biodiversidade e dos recursos ambientais, naturais e genéticos, através do paradigma da soberania alimentar e, na pauta mais recente: as múltiplas e simultâneas dimensões identitárias de gênero.

Nos territórios do MST, na Amazônia, pode-se observar que os saberes populares, aliados à luta política e à resistência por/nos territórios, amparam as vertentes da agroecologia política, que soam, não somente como luta política e social, mas também, como alternativa de enfrentamento da crise ambiental. Nossa abordagem mostra uma diferenciação nas práticas ecológicas desenvolvidas nos assentamentos do MST na Amazônia, resultado de uma ética/relação biocêntrica e ecocêntrica de natureza, onde o homem está inserido, não como administrador, mas como parte integrante dos ecossistemas. Estas práticas e vertentes estão amparadas, não poucas vezes nos saberes populares, em cosmovisões de mundo, na resistência por/nos territórios e na luta política e social das camponesas e dos camponeses do MST, no amplo mapa do desmatamento, em uma Amazônia marcada pelo pé do boi. O MST é o mais atuante movimento brasileiro que tem difundido pautas locais e concretas de resistência e tem contribuído nos paradigmas de uma luta singular de enfrentamento ao capital moderno-colonial-patriarcal em sua estrutura global que, mais que um modo de produção é um regime cultural e civilizatório. O MST é um movimento social de reapropriação social da natureza e reinvenção dos territórios.

\section{Agradecimento}

Ao Movimento dos Trabalhadores Rurais Sem Terra - MST de Rondônia. À Coordenação de Aperfeiçoamento de Pessoal de Nível Superior - Capes. Ao Programa de Pós-graduação em Geografia PPGG/UNIR. Ao grupo de pesquisa em Gestão do Território e Geografia Agrária da Amazônia - GTGA/UNIR/CNPq. 


\section{Geografias de Rondônia Território, Fronteira e Educação}

\section{REFERÊNCIAS}

ALENTEJANO, P. R. R. As políticas públicas do governo Bolsonaro para o campo: a contrarreforma agrária em marcha acelerada. Revista da Anpege, v. 16. n. 29, p. 353-392, Ano 2020.

ALTIERI, M. Agroecologia: A dinâmica produtiva da agricultura sustentável. Rio Grade do Sul: Ed. UFRGS, 2004.

CHAYANOV, A. V. La organización de la unidad económica campesina. Buenos Aires: Nueva Visión, 1974.

COSTA NETO, C.; CANAVESI, F. Sustentabilidade em assentamentos rurais: o MST rumo à 'reforma agrária agroecológica' no Brasil? Ecología política. Naturaleza, sociedad y utopia. Clacso, 2002.

COSTA SILVA, R. G.; LIMA, L. A. P; CONCEIÇÃO, F. S. Territórios em disputas na Amazônia brasileira: ribeirinhos e camponeses frente as hidrelétricas e ao agronegócio. Confins (Paris), v. 36, n. 36, p. 1-12, 2018. Disponível em: https://journals.openedition.org/confins/13980.

COSTA SILVA, R. G. Dinâmicas territoriais em Rondônia: conflitos na produção e uso do território no período de 1970/2010. Tese (Doutorado) USP, São Paulo, Brasil 2010a.

COSTA SILVA, R. G. Globalização e fragmentação do espaço agrário em Rondônia. RDE - Revista de Desenvolvimento Econômico, Ano XVI n. 30, Salvador, BA, 2014.

COSTA SILVA, R. G. Amazônia globalizada: da fronteira agrícola ao território do agronegócio - o exemplo de Rondônia. Confins (Paris), v. 23, p. 1-30, 2015. Disponível em: http://confins.revues.org/9949.

DESMARAIS, A. A. A. Via campesina: A globalização e poder do campesinato. São Paulo: Cultura Acadêmica; Expressão Popular, 2013.

FRADE, F.; SAUER, S. O MST e a experiência de agroecologia em assentamentos de reforma agrária no Brasil. Revista Latinoamericana de Estudios Rurales, II (3), 2017.

GUDYNAS, E. La ecología política del giro biocéntrico en la nueva Constitución de Ecuador, Revista de Estudios Sociales, 23, 2009a.

GUDYNAS, E. La senda biocéntrica: valores intrínsecos, derechos de la naturaleza y justicia ecológica. Tabula Rasa, n. 1, p. 45-71, 13, 2010.

LEFF, E. Racionalidade ambiental: a reapropriação social da natureza. Rio de Janeiro: Civilização Brasileira, 2006a.

LEFF, F. Saber Ambiental: sustentabilidade, racionalidade, complexidade, poder. 11 ed. Petrópolis: Vozes, 2015b. 
LEFF, E. Ecologia, capital e cultura: a territorialização da racionalidade ambiental. Petrópolis: Vozes, p. 439, 2009c.

MARTÍNEZ-ALIER, J. O ecologismo dos pobres: conflitos ambientais e linguagens de valoração. 2. ed. São Paulo: Contexto, 2018.

PORTO-GONCALVES, C. W. A nova questão agrária e a reinvenção do campesinato: o caso do MST. In: OSAL: Observatório Social de América Latina: Clacso, 2005a.

PORTO-GONÇALVES, C. W. A Ecologia política na América Latina: reapropriação social da natureza e reinvenção dos territórios. INTERthesis. Vol. 9, n. 1, jan./jun., 2012b.

PORTO-GONÇALVES, C. W. Lucha por la Tierra. Ruptura metabólica y reapropiación social de la naturaliza. Revista Latinoamericana, v. 15, n. $45,2016 \mathrm{c}$.

COELHO, F. A alma do MST? A prática da mística e a luta pela terra. Dourados: Ed. UFGD, 2014.

FLORIANI, D. Crítica da razão ambiental: pensamento e ação ambiental para a sustentabilidade. Sao Paulo: Annablume, 2013.

KOHLER, F.; NEGRÃO, M. P. The homeopathy/agroecology nexus: a discourse--centered analysis in a Brazilian agrarian settlement. Dialectical Anthropology,v. 42, p. 1-15, 2018.

GUZMÁN, E.; MOLINA, M. G. Sobre a evolução do conceito de campesinato. 2. ed. São Paulo: Expressão Popular, 2013.

MATOS, L. R.; COSTA SILVA, R. G.; THÉVENIN, J. M. R.; SOUZA. W. K. A. Ecologia humana no MST: os saberes-fazeres em forma de resistência em um assentamento agrário na Amazônia Brasileira. Retratos de Assentamentos, 23(1), 91-125, 2020.

MORIN, E. Ciência com consciência. Rio de Janeiro: Bertrand Brasil, 2000. MARQUES, J. Ecologia da alma. Petrolina: Franciscana, 2012a.

MARQUES, J. Ecologia do espírito. Petrolina, Franciscana, 2016b.

MOSCAL, J. dos S. Sentimentos da luta: música e mística no movimento dos trabalhadores rurais sem-terra. Tese (doutorado) em Antropologia Social, Univer- sidade Federal de Santa Catarina, Florianópolis, p. 283, 2017.

OFICINA NACIONAL DE MÚSICOS DO MST. Musicoteca (Movimento dos Trabalhadores Rurais Sem Terra). 2016. Disponível em: https://mst.org. br/2016/05/30/i-oficina-nacional-de-musicos-do-mst/. acesso em: 28 out. 2021. 


\section{PARTE 2}

\section{ESPAÇO AGRÁRIO, AGRICULTURA FAMILIAR E AGRONEGÓCIO}




\title{
ESPECIALIZAÇÃO PRODUTIVA REGIONAL: UMA ABORDAGEM SOBRE O AGRONEGÓCIO DA SOJA NO SUL DE RONDÔNIA ${ }^{1}$
}

\author{
Juander Antonio de Oliveira Souza"
}

\section{INTRODUÇÃO}

O recorte temporal compreende o período de 1998 a 2018, o início corresponde a implantação da Hidrovia do Madeira com o porto graneleiro na cidade de Porto Velho, que impulsionou o agronegócio rondoniense e o deixou mais competitivo, com os novos sistemas de ações e objetos incorporados ao espaço da Região Produtiva do Agronegócio RPA de Vilhena, alterou as estruturas preestabelecidas, a partir da espacialização do agronegócio com a produção de grãos (soja e milho) e pecuária.

A colonização oficial de Rondônia foi a partir dos projetos de colonização implantados pelo governo militar na década de 1970, como condicionantes históricos e geográficos para compreender o processo de transformação ocorrido em Rondônia pelo trabalho social. Tem-se a preocupação de compreender os processos de modernização do território a partir da verticalização das atividades produtivas, que buscou atender demandas externas com o que Santos (1978) designa de "espaços derivados" onde a organização se dá mais pela vontade remota do que pela organização dos próprios lugares. Na década de 1970, o Brasil entra em uma fase de transformação do setor industrial e modernização da agricultura, e passa a figurar entre os principais produtores mundiais de grãos até a atualidade.

O trabalho envolve algumas categorias de análise, com destaque ao território que possibilitou compreender a metamorfose que essa

\footnotetext{
${ }^{1}$ Publicado em: SOUZA, Juander Antônio de Oliveira. Especialização produtiva regional: uma abordagem sobre o agronegócio da soja no sul de Rondônia. Ciência Geográfica, Bauru, XXV - Vol. XXV - (2), p. 695-717, jan./dez., 2021.

" https://orcid.org/0000-0002-7238-9460
} 


\section{Geografias de Rondônia Território, Fronteira e Educação}

região passa com o avanço do agronegócio da região Centro-Oeste do país para o Sul do estado de Rondônia, sendo o município de Vilhena um território modernizado, tecnificado e verticalizado com a produção agrícola da soja se espacializando para os municípios circunvizinhos.

Com a globalização da economia, ocorre o processo de produção e circulação de mercadorias entre as diversas regiões do planeta, em um ritmo cada vez mais acelerado. A produção espacial floresce a sobrevivência do capitalismo com a acumulação do capital. Isso é possível devido ao avanço da ciência que produz um sistema técnico onde a informação é difundida, possibilita às empresas uma mais-valia universal (Santos, 2008).

$\mathrm{Na}$ busca por ampliação dos resultados financeiros, as organizações produtivas se deslocam para regiões que oferecem maiores vantagens para o capital, e passa modificar as dinâmicas em escala local ou regional a partir da incorporação de capitais fixos no território, com aplicação de inovações tecnológicas na agricultura, e adapta a região que está se inserindo.

Com a dinâmica de produção e reprodução dos espaços agrícolas e urbanos, associados ao processo de reestruturação da agropecuária brasileira, surge os novos arranjos territoriais, no qual Elias (2013) designa de Regiões Produtivas do Agronegócio (RPA). As RPAs são os novos territórios das redes agroindustriais que recebem expressivos investimentos do agronegócio globalizado, e se torna mais competitiva, passa a fazer parte dos circuitos espaciais da produção e círculo de cooperação de commodities agrícola (Elias, 2011).

Para atender a demanda global, o agronegócio (re)estrutura o território dentro de uma dialética espacial de modernização e desigualdades socioespaciais regionais. O constante movimento do capital, é responsável pelas alterações no espaço geográfico, pelas inovações tecnológicas e avanço da modernização, ocorrendo a expansão da fronteira agrícola. O agronegócio soja circula de forma global e, onde se insere, dá uma nova dinâmica ao campo e a cidade e (re)estrutura a região que se encontra, sendo importante proceder pela análise regional dos efeitos que a cultura promove sobre a socioeconomia, sua inserção não se restringe apenas ao município, ultrapassando seus limites territoriais e influenciando as dinâmicas socioeconômicas já estabelecidas.

A expansão da agricultura no cerrado mato-grossense tornou o município de Sorriso o maior produtor de soja do país, estruturando o comércio para dar suporte a produção com a instalação de empresas e 


\section{Especialização produtiva regional: uma abordagem sobre o agronegócio da soja no Sul de Rondônia}

escritórios de grandes grupos empresariais que investiram no município e impulsionou o agronegócio (Bernardes, 2010). Cidade como Sapezal no oeste mato-grossense nasceu do agronegócio com a produção de soja, milho e algodão. A circulação de grãos e a criação de um eixo de exportação foram as condições básicas para a fundação de Sapezal (Barbosa, 2011).

Nos municípios de Barreiras e Luiz Eduardo Magalhães no oeste da Bahia, instalou-se algumas das principais empresas do agronegócio como a Bunge, Cargill, ADM, Amaggi, LDC, Noble, Multigrain e SLC, trabalhando com uma combinação da economia de escala, gestão profissional e acesso aos mercados de capitais, sufocando os pequenos produtores, promovendo a concentração fundiária com a expansão da monocultura, desestruturando o campesinato e surgindo uma urbanização desordenada (Santos, 2015; Castillo et al., 2016). Esse fato ocorrido nos municípios de Barreiras e Luiz Eduardo Magalhães, assim como em Sapezal, se repete no município de Vilhena com a implantação dos grupos hegemônicos como a Bunge, Cargill, Amaggi, Grupo Masutti, e dezenas de outras filiais com produtos e serviços agrícolas encontrados nas regiões produtoras de grãos por todo o país.

Com a inserção do agronegócio, os pequenos agricultores ficam a margem da acumulação ampliada do capital, muitos são expulsos de suas terras, outros resistem por conta própria, já os produtores médios, podem se manter graças a diversificação das atividades prestando serviços a agricultura empresarial (Castillo et al., 2016). As RPAs sempre estão em busca de novas áreas que ofereçam vantagens competitivas e garanta sua existência.

A atividade agrícola e pecuária, conjuga produção, processamento, distribuição, circulação e consumo dos produtos, por meio de um sistema agroindustrial complexo, podendo dinamizar e influenciar a estrutura geográfica espacial do campo e da cidade onde se implanta. A abordagem regional possibilita compreender as mudanças na dinâmica socioeconômica e estrutura espacial, com as particularidades que distingue ou aproxima uma região da outra.

Em Rondônia, na região central do estado no eixo da BR-364 encontra-se uma fragmentação do território ocupado por pequenas propriedades devido à distribuição de terras nos projetos de colonização com áreas inferiores a 100 hectares para o colono migrante, não havendo a reconcentração fundiária, com a consolidação da pecuária, apresentando grande produção de leite. Essas pequenas propriedades 


\section{Geografias de Rondônia Território, Fronteira e Educação}

inviabiliza a monocultura da soja, devido à fragmentação territorial e a valorização da terra. A soja precisa de grandes extensões de terras agricultáveis, para viabilizar o investimento em máquinas e implementos utilizados para plantio, tratos culturais e colheita. Ao contrário da soja, a produção de bovinos de corte e leite, necessita de menor investimento e pode ser praticada em qualquer tamanho de propriedade. A produção de leite é encontrada na maioria das pequenas propriedades como complemento de renda e os bezerros como investimento ou poupança.

Para a realização desse trabalho, as pesquisas consistiram no levantamento bibliográfico em leituras de livros, artigos, teses, relacionados a geografia agrária e regional e contextualização local, disponíveis em formato físico e digital, vinculados ao agronegócio com a produção de soja, e a cidade do agronegócio, verticalizado em Vilhena. O trabalho de gabinete buscou informações em sites como o IBGE, Conab, MDIC, Jucer-RO, Idaron, entre outros, a respeito da produção de soja na região, área plantada, mercado de trabalho e dados demográficos. O trabalho contempla resultados de uma pesquisa de tese de doutoramento em geografia, sobre a regionalização da soja e a formação da cidade do agronegócio na RPA de Vilhena, importante região produtora de grãos no estado de Rondônia, responsável por $70 \%$ da produção estadual de grãos, localizada no Sul do estado.

\section{A especialização produtiva regional NO ATUAL PERÍOdo téCNICO- -CIENTÍFICO-INFORMACIONAL}

Uma transformação relacionada à soja no município de Vilhena em Rondônia, por ser a pioneira no cultivo do grão acabou por se tornar o polo de referência da atividade agrícola, ocorrendo a difusão nos municípios adjacentes, com a implantação e instalação de infraestrutura como silos de armazenagem, secadores de grãos, implantação de escritórios de grandes empresas como a Bunge, Cargill e Amaggi, promovendo o fortalecimento e espacialização da soja aos municípios circunvizinhos.

Nos últimos anos, a soja vem avançando para outras regiões rondonienses, ocupa espaço de outras atividades agrícolas já praticadas na região, na medida em que se instaura a territorialização do capital. Essa expansão provoca conflitos agrários devido à valorização da terra para a ampliação das áreas com lavouras de grãos, fazendo com que áreas ocupadas por posseiros, venham ser requisitadas pelos antigos proprietários, fomentando novas invasões de áreas protegidas como terras da 


\section{Especialização produtiva regional: uma abordagem sobre o agronegócio da soja no Sul de Rondônia}

União, terras indígenas, unidades de conservação, dentre outras. A soja ocupa as áreas de pastagens, deslocando a pecuária já consolidada na região para outras regiões do estado, fazendo pressão na abertura de novas áreas para pastagens. Para Costa Silva (2014) a substituição da atividade pecuária pela soja reduz o rebanho bovino nos municípios onde a soja avança, desloca o rebanho para áreas ao norte e noroeste de Rondônia, devido à compra ou arrendamento das terras, decorrente da capitalização que a agricultura globalizada promove.

O crescimento da área plantada de soja pressiona a área destinada à produção bovina, que continua ascendente em outros municípios, num movimento migratório constante nos últimos anos, promove a abertura de novas áreas com soja, expulsando os camponeses, seja pela compra, arrendamento de terras, uso de agrotóxicos, ou retomada de áreas ocupadas por posseiros pelos antigos proprietários das áreas concedidas por meio de concessão do governo a partir dos Contratos de Promessa de Compra e Venda - CPCVs, Contrato de Concessão de Terras Públicas - CCDTPs, Contrato de Alienação de Terras Públicas - CATPs, os quais deveriam seguir regras contratuais. Nos municípios onde há implantação da sojicultora, esta atividade se torna predominante, sobrepondo as demais atividades praticadas de forma tradicional e já consolidada.

É importante a compreensão dessas dinâmicas por meio das relações que são estabelecidas para o crescimento e espacialização da soja e pecuária, para entender os efeitos dessa transformação na região estudada. Uma vez conhecido os efeitos da espacialização da sojicultura numa região, o Estado pode estabelecer políticas públicas para coordenar e planejar essas mudanças em novas áreas, não sendo a revelia do capital, mas evitando que efeitos negativos, sociais e ambientais ocorram. $\mathrm{O}$ poder público pode se antecipar a ocorrências de conflitos agrários por disputa de terras que ainda não estão destinadas ou legalizadas juridicamente, criar espaço para a (re)produção do campesinato, planejar estrategicamente o desenvolvimento do estado por regiões de afinidade, dentre outras possibilidades de ordem econômica, ambiental e social.

Para entender a dinâmica do avanço da soja no Sul de Rondônia, faz necessário conhecer a dinâmica produtiva dos municípios de Comodoro, Campos de Júlio e Sapezal na região Oeste do estado de Mato Grosso, municípios sojicultores adjacentes à cidade de Vilhena que já praticavam a sojicultura antes de Vilhena, propiciando a vinda de produtores para o município de Vilhena. A abertura da Hidrovia do Madeira com o Porto Graneleiro em Porto Velho, inaugurado em 1997 


\section{Geografias de Rondônia Território, Fronteira e Educação}

pelo Grupo Amaggi para escoamento de grãos da região oeste mato-grossense e recebimento de insumos, melhora a logística de escoamento dos grãos rondoniense.

A abertura da Hidrovia do Madeira tornou o cultivo da soja competitivo para Vilhena com essa rota logística hidro-rodoviária, BR-364/ Hidrovia do Madeira. A partir de 1997 a soja emerge como commodity e passa a impor sua dinâmica territorial, que vem do global ao local, reconfigurando o espaço nacional (Costa Silva, 2014a), de forma a permitir fluidez territorial (Arroyo, 2003) tendo a maior parte da produção exportada ao exterior. Ocorre o crescimento de área plantada a cada safra despertando o interesse de produtores já instalados na região, e a vinda de produtores do oeste do Mato Grosso, além de produtores do Sul do país.

Com o cultivo da soja na Região de Vilhena, muitas propriedades disponibilizadas pelo governo por meio de concessão e leilões através dos CATPs, CPCVs, CCDTPs que haviam sido abandonadas, foram reivindicadas suas posses devido à valorização da terra na região, ocorrendo disputas com posseiros que ocupam essas propriedades e os antigos proprietários. No ano de 2018, a Região de Vilhena concentrou cerca de $25 \%$ dos conflitos agrários por disputa de terra no estado de Rondônia (CPT, 2019).

Em decorrência da espacialização da soja no município de Vilhena, podem ser observados alguns elementos como uma rede de objetos técnicos prestadores de serviços, silos de armazenagem, concessionárias de máquinas e implementos agrícolas voltados para atender o agronegócio da soja. Aspectos relacionados à topografia e a predominância de extensão do cerrado mato-grossense, temperatura e condições edáficas que favorecem a produção de soja são aspectos que contribuíram para a espacialização da soja no Sul de Rondônia. Além desses aspectos, o município está localizado num entroncamento entre às margens da Rodovia BR-364 e BR-174 que cortam o perímetro urbano de Vilhena. Importantes vias que servem como corredor logístico, sendo que Vilhena é o município polo da região que leva seu nome, composta pelos municípios de Vilhena, Cabixi, Colorado do Oeste, Chupinguaia, Corumbiara, Cerejeiras e Pimenteiras do Oeste em, razão da concentração de indústrias, empresas e comércio com prestação de serviços e produtos, educação e saúde, sendo conhecida como "Portal da Amazônia" em Rondônia (Ricarte, 2017; Extra de Rondônia, 2017). 


\section{Especialização produtiva regional: uma abordagem sobre o agronegócio da soja no Sul de Rondônia}

A Hidrovia Madeira-Amazonas vem impondo uma nova dinâmica na logística, favorece a produção agrícola em Rondônia e na região Oeste do Mato Grosso. Conforme destacado por Santos (1996), esses investimentos em infraestrutura modifica as relações multiescalares dos agentes territoriais e do lugar onde se materializa. A hidrovia permite o fluxo da mercadoria globalizada com possibilidade de expansão e ganhos econômicos aos agentes locais e, com o avanço da soja sobre a produção familiar, ocorre a migração campo-campo e campo-cidade, promove o êxodo rural e o crescimento urbano (Ricarte, 2017). A hidrovia do Madeira faz a ligação do porto de Porto Velho-RO aos portos de Itacoatiara-AM e Santarém-PA, fazendo a logística hidroviária de mercadorias e insumos globais e nacionais. A hidrovia funciona articulando o fluxo do agronegócio globalizado, gerando uma nova configuração geográfica em Rondônia com a regionalização da produção de grãos de soja e milho no sul do estado (Costa Silva, 2005).

Com a regionalização produtiva no Sul de Rondônia, o município de Vilhena se adapta para atender a demanda crescente do campo em decorrência da materialização do capital e implantação de fixos para se consolidar e especializar no agronegócio soja. Essa materialização do capital promove um desenvolvimento incompleto da metamorfose do progresso no discurso do agronegócio, sendo incentivado pelo poder público através de políticas do Estado, gera conflitos agrários resultante do agronegócio na região e fora dela.

A área territorial da região de Vilhena é de, aproximadamente, $31.448 \mathrm{~km}^{2}$. A principal influência do fluxo migratório foi a implantação do Plano de Integração Nacional (PIN) que o estado recebeu em seus ciclos de ocupação, o que propiciou a criação de Vilhena e outros municípios, seguindo a mesma lógica de ocupação da região amazônica. A Figura 1 mostra a localização da região de Vilhena. O município de Vilhena é o maior da região em número de habitantes e desenvolvimento econômico. 


\section{Geografias de Rondônia Território, Fronteira e Educação}

Figura 1 - Localização da área de estudo: RPA de Vilhena.

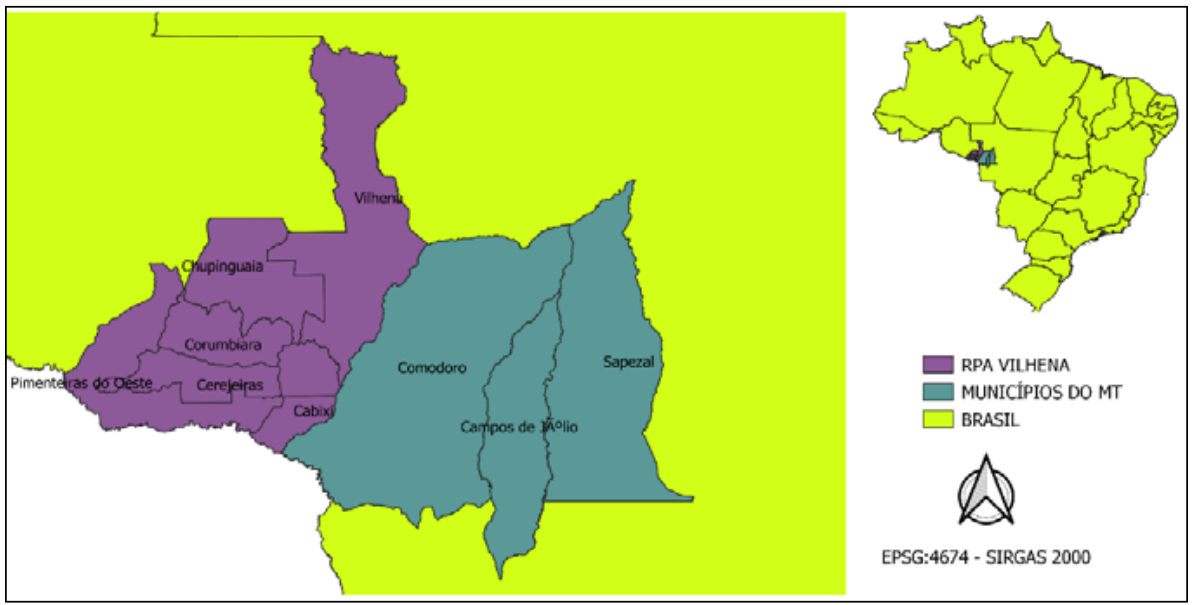

Fonte: IBGE/Censo Agropecuário, 2017. Organização: SOUZA, J. A.

A ocupação da região de Vilhena nos anos 1970 se deu por meio do Projeto Integrado de Colonização-PIC, Projeto de Assentamento Dirigido-PAD, Projeto de Assentamento Rápido-PAR, e licitações de áreas de terras realizada pelo governo por meio de concessão e leilões (CATPs, CPCVs, CCDTPs).

As propriedades rurais na Região de Vilhena, já nasceram grandes, voltadas para grandes proprietários e grupos empresariais. Uma área de aproximadamente 1.200.000ha localizada na Gleba Corumbiara foi posta em licitação pública em 1972, com lotes variando de 200 a 2.000ha (Fonseca, 2015; Martins, 2009).

A licitação da Gleba Corumbiara foi destinada para a produção pecuária, sendo adquirida por grupos empresariais da região centro sul do país, que se tornaram grandes latifúndios improdutivos para a aquisição especulativa (Cunha, 1985).-

\section{Mudanças no Uso e Apropriação da Terra: a Regionalização do Agronegócio EM Rondônia}

A produção de commodity agrícola se expande pela Amazônia brasileira com investimentos aplicados na região para consolidar a agricultura capitalista com a monocultura da soja que tem ganhado o espaço 


\section{Especialização produtiva regional: uma abordagem sobre o agronegócio da soja no Sul de Rondônia}

territorial. A produção de grãos é crescente desde o fim da década de 1990, quando as pastagens do cerrado são substituídas pela plantação de grãos, ligado ao fenômenos de novos espaços produtivos, com novos potenciais e múltiplos condicionantes, como incentivos governamentais e terras a preços menores que os praticados para a produção de grãos em outras regiões do país.

A soja melhora o rendimento por hectare a cada safra, ganhando o espaço rondoniense com variedades desenvolvidas para as diferentes regiões do estado e a aplicação de tecnologias no campo como pode ser visto no Gráfico 1. Foram desenvolvidas variedades de soja com diferentes ciclos de maturação para as distintas regiões do estado, com produtividade semelhante à média nacional, despertando o interesse de produtores. A soja proporciona maiores ganhos que pecuária e menor tempo de giro, porém, apresenta maiores riscos e necessita de grandes investimentos em máquinas e implementos agrícolas, além do preparo do solo, que deve ser completamente limpo.

Gráfico 1 - Rondônia, soja série histórica safra 1997/1998 a 2018/19, produção e área plantada.

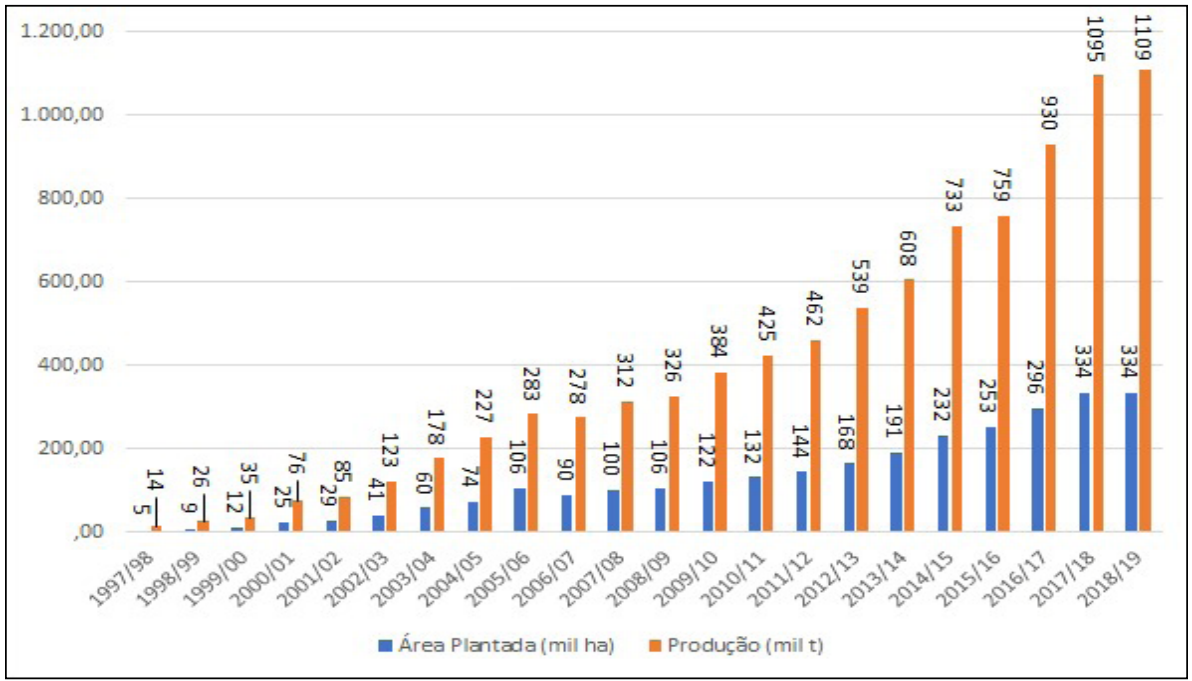

Fonte: IBGE/PAM, 2019. Organização: SOUZA, J. A. O. 


\section{Geografias de Rondônia Território, Fronteira e Educação}

Na safra de 1997/98 a área cultivada com soja em Rondônia foi de 7,8 mil hectares. Em duas décadas multiplicou mais de 40 vezes chegando 334 mil hectares na safra 2018/19. No mesmo período a produção saiu de 14 mil para 1,1 milhão de toneladas (Gráfico 1).

Conforme levantamento apresentado pelo pesquisador da Embrapa Rondônia Vicente Godinho, "estima-se que 70\% das áreas de pastagens do estado estão com algum grau de degradação, e o cultivo da soja vem como uma alternativa para a recuperação destes solos, realizando o sistema de integração lavoura-pecuária - ILP" (Costa Silva, 2016). É possível perceber um potencial de crescimento para a agricultura rondoniense, atualmente as lavouras ocupam apenas $5 \%$ da área disponível do estado.

Com a modernização do campo, a produção agrícola deixa de ser de subsistência para atender as demandas das cidades. Parte da população rural deixa o campo e migra para as cidades em busca de trabalho, a mão de obra agrícola deixa de ser exclusivamente rural, entrando em cena o trabalhador volante. A cidade passa a ser um elemento impulsionador do desenvolvimento e aperfeiçoamento das técnicas, reúne profissionais e intercambio entre eles, com a criação e disseminação de conhecimento (Santos, 2014).

Tabela 1 - População da Região de Vilhena, Censos Demográficos de 2000 e 2010.

\begin{tabular}{|c|c|c|c|c|c|c|c|c|c|}
\hline \multirow[b]{2}{*}{ Cidade/Ano } & \multicolumn{3}{|c|}{2000} & \multicolumn{6}{|c|}{2010} \\
\hline & $\begin{array}{l}\text { Pop. } \\
\text { Total }\end{array}$ & \begin{tabular}{|l} 
Pop. \\
Urbana
\end{tabular} & $\begin{array}{l}\text { Pop. } \\
\text { Rural }\end{array}$ & Pop. Total & $\Delta \%$ & Pop. Urbana & $\Delta \%$ & Pop. Rural & $\Delta \%$ \\
\hline Cabixi & 7518 & 2672 & 4846 & 6313 & $-16,03 \%$ & 2693 & $0,79 \%$ & 3620 & $-25,30 \%$ \\
\hline Cerejeiras & 18207 & 14846 & 3361 & 17029 & $-6,47 \%$ & 14419 & $-2,88 \%$ & 2610 & $-22,34 \%$ \\
\hline Colorado do Oeste & 21892 & 14576 & 7316 & 18591 & $-15,08 \%$ & 13657 & $-6,30 \%$ & 4934 & $-32,56 \%$ \\
\hline Chupinguaia & 5521 & 1954 & 3567 & 8301 & $50,35 \%$ & 3663 & $87,46 \%$ & 4638 & $30,03 \%$ \\
\hline Corumbiara & 10459 & 2073 & 8386 & 8783 & $-16,02 \%$ & 2590 & $24,94 \%$ & 6193 & $-26,15 \%$ \\
\hline $\begin{array}{l}\text { Pimenteiras do } \\
\text { Oeste }\end{array}$ & 2527 & 1398 & 1129 & 2315 & $-8,39 \%$ & 1292 & $-7,58 \%$ & 1023 & $-9,39 \%$ \\
\hline Vilhena & 53598 & 50601 & 2997 & 76202 & $42,17 \%$ & 72218 & $42,72 \%$ & 3984 & $32,93 \%$ \\
\hline Total & 119722 & 88120 & 31602 & 137534 & $14,88 \%$ & 110532 & $25,43 \%$ & 27002 & $-14,56 \%$ \\
\hline
\end{tabular}

Fonte: IBGE/Censo Demográfico (2000, 2010). Organização: SOUZA, J. A. O.

A Tabela 1 traz o resultado dos dois últimos Censos Demográficos referentes ao ano de 2000 e 2010, apresentando a variação populacional entre os municípios da Região de Vilhena. Os municípios de Cabixi, 


\section{Especialização produtiva regional: uma abordagem sobre o agronegócio da soja no Sul de Rondônia}

Cerejeiras, Colorado do Oeste, Corumbiara e Pimenteiras do Oeste, apresentaram uma redução na população total, sendo mais significativa em termos percentuais a redução da população rural.

Os municípios de Chupinguaia e Vilhena apresentaram um crescimento populacional total de 50,35\% e 42,17\%, com um aumento da população rural de 30,03\% para Chupinguaia e 32,93\% para Vilhena. Conforme estimativa do IBGE para o ano de 2018, a população total da Região de Vilhena continua crescente, com cerca de 156.201 habitantes (IBGE, 2019) e um crescimento acumulado do ano de 2010 para 2018 de aproximadamente $12 \%$.

Os municípios que pertencem à Região de Vilhena, seguiu a mesma dinâmica de ocupação e povoamento dos projetos de colonização do estado de Rondônia, mantendo sua base econômica assentada na agropecuária, se especializando com a produção de grãos a partir do agronegócio com o commodity soja por meio de investimentos de capital no campo e na cidade, tornando-se uma grande produtora de grãos.

A Tabela 2 mostra o panorama dos municípios pertencentes a Região de Vilhena, com o pessoal ocupado, o PIB per capta e a estimativa da população para o ano de 2019. O salário médio do trabalhador formal no ano de 2017 para a região ficou em 1,9 salários mínimos. Vilhena foi o município que pagou o maior salário (2,1 salários) e Colorado do Oeste foi o que pagou o menor salário (1,8 salários). Com relação ao Pessoal Ocupado-PO, Vilhena apresenta o maior quantitativo com 21.925 pessoas (22,9\% da população). Em termos percentuais o município que tem menos PO é Corumbiara, com 9,3\%, já em termos quantitativos de PO, Pimenteiras do Oeste apresenta o menor número com apenas 346 pessoas, visto que é o município que possui a menor população. 


\section{Geografias de Rondônia Território, Fronteira e Educação}

Tabela 2 - Municípios da Região de Vilhena, salário médio do trabalhador formal, Pessoal Ocupado, PIB per capta, IDH, População estimada em 2019.

\begin{tabular}{l|c|c|c|c|c|c|c}
\hline $\begin{array}{c}\text { Municipios da Região de } \\
\text { Vilhena }\end{array}$ & $\begin{array}{c}\text { Salário } \\
\text { trabalhador } \\
\text { formal (2017) }\end{array}$ & $\begin{array}{c}\text { Pessoal } \\
\text { Ocupado } \\
(2017)\end{array}$ & $\begin{array}{c}\text { Pessoal } \\
\text { Ocupado } \\
\%\end{array}$ & $\begin{array}{c}\text { PIB per } \\
\text { capita } \\
2017(\mathrm{R} \$)\end{array}$ & IDH 2010 & $\begin{array}{c}\text { População } \\
\text { Estimada em } \\
2019\end{array}$ & $\begin{array}{c}\text { Variação \% da } \\
\text { população } \\
\text { estimada }\end{array}$ \\
\hline Corumbiara & 1,9 & 809 & 9,3 & $38.156,05$ & 0,613 & 7.391 & $-15,85 \%$ \\
\hline Cerejeiras & 2 & 2.600 & 14,5 & $25.009,71$ & 0,692 & 16.323 & $-4,15 \%$ \\
\hline Colorado do Oeste & 1,8 & 2.535 & 13,7 & $18.413,74$ & 0,685 & 15.882 & $-14,57 \%$ \\
\hline Chupinguaia & 1,9 & 2.282 & 21,5 & $26.504,59$ & 0,652 & 11.182 & $34,71 \%$ \\
\hline Cabixi & 1,7 & 645 & 10,4 & $22.314,80$ & 0,65 & 5.312 & $-15,86 \%$ \\
\hline Pimenteiras do Oeste & 1,9 & 346 & 14,4 & $41.089,77$ & 0,665 & 2.169 & $-6,31 \%$ \\
\hline Vilhena & 2,1 & 21.925 & 22,9 & $26.723,64$ & 0,731 & 99.854 & $31,04 \%$ \\
\hline
\end{tabular}

Fonte: IBGE/Censo Demográfico (2000 e 2010). Organização: SOUZA, J. A. O.

O maior PIB per capita no ano de 2017 foi de Pimenteiras do Oeste ( $\mathrm{R} \$ 41.089,77)$ e o menor foi Colorado do Oeste (R $\$ 18.413,74)$. No ano de 2010, o maior Índice de Desenvolvimento Humano foi o de Vilhena $(0,731)$ e o menor de Corumbiara $(0,613)$. No quesito população, a estimativa do IBGE para o ano de 2019 se mantém conforme a variação apresentada na Tabela 1 . O município de Vilhena e Chupinguaia apresentaram uma estimativa de crescimento populacional para o ano de 2019 de $34,71 \%$ e $31,04 \%$, enquanto os demais apresentaram uma estimativa de redução (Tabela 2).

Pode ser visto na Tabela 2, que Vilhena faz jus como cidade polo regional, apresenta um crescimento constante gerando emprego e apresenta o maior salário médio da região estudada e melhor IDH municipal, absorve parte da população que deixa os municípios vizinhos e vão em busca de emprego na cidade.

O agronegócio tem contribuído com o saldo da balança comercial nacional, com as exportações de produtos agropecuários e agroindustrializados. As exportações do setor primário rondoniense somaram US\$ 1,29 bilhão de dólares em 2019, superando as exportações de 2018 em $3,2 \%$. Houve um aumento na produção de milho e soja em relação à safra passada, além da exportação de carne bovina que ganhou novos mercados internacionais. Nesse mesmo ano, $76 \%$ das exportações rondonienses estava concentrada em dois produtos, grãos de soja e pecuária. 


\section{Especialização produtiva regional: uma abordagem sobre o agronegócio da soja no Sul de Rondônia}

O Gráfico 2 apresenta a evolução da agropecuária rondoniense entre os anos de 2002 a 2016. A produção agropecuária foi sempre crescente, aumentando as exportações. Comprova-se que o poder público trabalha com políticas públicas voltadas para incentivar e expandir o agronegócio, amarrado aos processos da globalização que invade áreas rurais menos dinâmicas nos espaços de reserva.

O agronegócio tem políticas de incentivo e, talvez, uma das mais importantes ao setor é a Lei Kandir, e o campo responde aos incentivos com a crescente produção de commodities.

Gráfico 2 - Rondônia: valor adicionado bruto a preços correntes da agropecuária (Mil reais), 2002-2016.

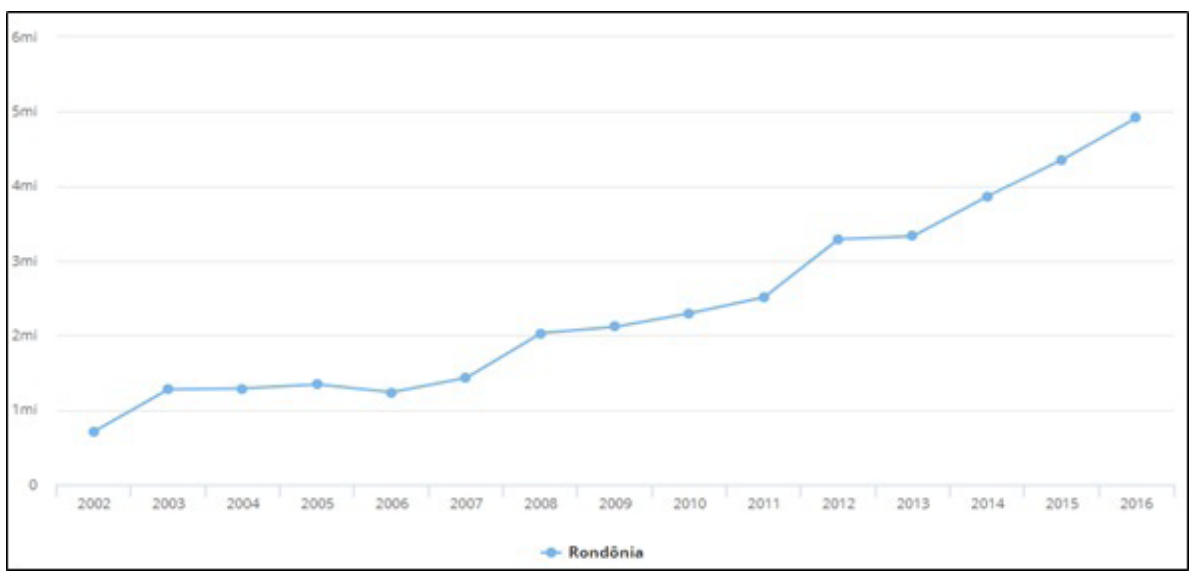

Fonte: IBGE/Estatísticas Econômicas, 2019.

O estado de Rondônia, com a produção de soja inaugura a formação dos espaços luminosos, onde a expansão agrícola gesta uma particularidade no espaço agrário regional formando a região do agronegócio soja, com o uso do território pelas grandes empresas do capital globalizado (Costa Silva, 2014), como Bunge, Cargill, Amaggi, e o Grupo Masutti Agropecuária. Este último surge em Vilhena sendo um grande produtor de grãos com o cultivo de mais de 100.000 ha, distribuídos entre os estados de Rondônia e Mato Grosso (Souza, 2019).

O espaço rural se moderniza subordinado ao agronegócio e a cidade se (re)organiza para atender as demandas do campo com a pro- 


\section{Geografias de Rondônia Território, Fronteira e Educação}

dução de grãos na Região de Vilhena surgindo a "cidade do agronegócio" se reestruturando de acordo com as necessidades da expansão da produção agrícola. Começa uma intensa relação entre campo-cidade, (re)organizando o território e resultando em novos arranjos territoriais, nova Região Produtiva do Agronegócio na Região de Vilhena, sobretudo o município de Vilhena, expressa bem essa realidade.

Os atores hegemônicos agem na conquista das verticalidades e das solidariedades organizacionais, o campo e a cidade ficam à mercê do mercado global, o mesmo que dita as regras. Nas RPAs, as grandes corporações agroindustriais são os maiores agentes produtores do espaço agrário e urbano com poder de promover significativas (re)estruturações urbanas e regionais (Elias, 2011).

A globalização promove a integração dos mercados direcionando para atividades econômicas específicas, atende à demanda doméstica e estrangeira. O governo por sua vez, fornece investimentos, sanciona leis e regulamentos, fecha parcerias, fornece infraestrutura, para formar as cadeias produtivas (Neves, 2005), que instaladas e estabilizadas vão se desenvolver e levar consigo outros segmentos que atuam de forma direta e indireta. As regiões onde se desenvolve tais atividades sofrem alterações promovidas pelo desenvolvimento econômico local, onde os municípios adquirem as características das realidades regionais e modifica as configurações do espaço geográfico e a dinâmica da sociedade.

A produção agrícola moderna construiu um cenário de elementos técnicos, dominantes na paisagem regional, diferenciando o moderno na atualidade, e as formas de atuação no passado (Bernardes, 2009). O campo é dominado pelo capital com investimentos em insumos voltados para a produção, as cidades do agronegócio passam a ser meras regiões do fazer, segue as regras do mercado internacional.

\section{O AGRONEGÓCIO EM RONDÔNIA}

A Região de Vilhena é a maior produtora de grãos do estado, com escritórios e armazéns dos grupos hegemônicos como Cargill, Bunge, Grupo Amaggi, e Grupo Masutti, e na área da pecuária conta com dois frigoríficos de abate de bovinos, localizados em Vilhena e Chupinguaia, sendo estes, fatores que propiciaram o desenvolvimento agrícola e pecuário da região.

O rebanho bovino rondoniense sempre foi crescente saindo de 4,3 milhões de bovinos em 1997 para 14,3 milhões em 2018. Na Região 


\section{Especialização produtiva regional: uma abordagem sobre o agronegócio da soja no Sul de Rondônia}

de Vilhena, para o mesmo período o crescimento do rebanho bovino foi de 640 mil para 1,4 milhões de bovinos (Idaron, 2018).

Além da pecuária, é apresentado os quatro produtos agrícolas com produção representativa para o estado desde a década de 1970 quando deu início a colonização dirigida até a atualidade, sendo o milho, arroz, café e a soja no final dos anos de 1990.

O primeiro produto de destaque é o arroz, produzido desde o período da colonização como cultura de subsistência pela maioria dos colonos, com comercialização do excedente. $\mathrm{Na}$ atualidade, muitos produtores utilizam o cultivo de arroz em áreas recém-abertas, alegando que o arroz "amansa a terra", após dois ou três ciclos do arroz entra com a produção do outro produto. Os produtores de grãos não investem no cultivo do arroz como lavoura temporária contínua que se cultiva todas as safras, mas sim como uma atividade de área recém-aberta para fazer a correção do solo.

Gráfico 3 - Produção de arroz (hectares) na RPA de Vilhena e Rondônia, 1997 a 2018.

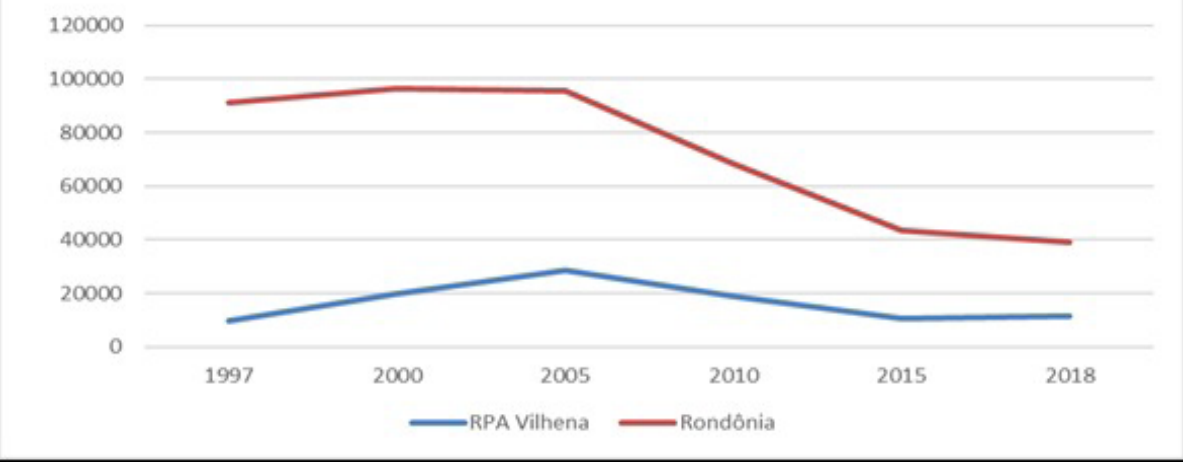

Fonte: IBGE/PAM, 2019. Organização: SOUZA, J. A. O.

O Gráfico 3, traz a série histórica da produção de arroz em Rondônia e na Região de Vilhena entre os anos de 1997 a 2018. A produção estadual manteve-se praticamente constante de 1997 a 2005 saindo de 91.326 para 95.539 hectares. Porém, de 2010 para 2015 houve uma 


\section{Geografias de Rondônia Território, Fronteira e Educação}

queda no plantio de $54 \%$, nos anos seguintes continuou reduzindo a área de plantio totalizando apenas 39.063 hectares em 2018 .

A produção do arroz na RPA de Vilhena acompanhou os períodos de crescimento ocorrido no estado, em 1997 representava 10,8\% da área cultivada no estado, sendo ascendente até o ano de 2005 com um crescimento de $180 \%$ chegando a 28.538 hectares, fechando o ano de 2015 com uma redução de 62,6\%. O ano de 2018 teve um leve crescimento e ficou com 11.500 hectares e representou $29,4 \%$ da produção estadual. A Região de Vilhena é uma importante produtora de grãos no estado com o cultivo do arroz, produto que faz parte da cesta básica, estando diariamente na mesa do brasileiro.

Analisando a produção do milho, nos anos 1990 não era cultivado em larga escala na Região de Vilhena. O maior produtor era Colorado do Oeste com uma área de 4.318 hectares. Em 2005 Vilhena passa a liderar o ranking de produção de milho com uma área de 13.000 hectares sendo crescente a cada safra, com o maior pico no ano de 2015 cultivando 42.050 hectares. Seguindo o mesmo arranque de Vilhena, se destaca Cerejeiras com um crescimento acentuado em 2010 com 18.450 hectares, um aumento de 6,3 vezes em relação ao ano de 2005 . Esse aumento da área cultivada está atrelado ao cultivo da soja, sendo o milho a segunda safra.

Gráfico 4 - Produção de milho em hectares Rondônia e RPA de Vilhena 1997 a 2018

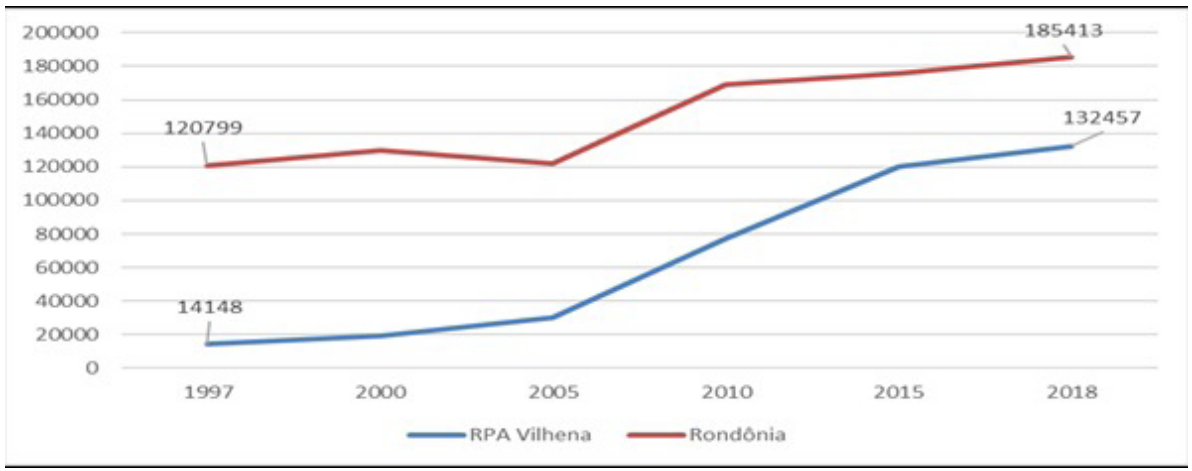

Fonte: IBGE/PAM, 2019. Organização: SOUZA, J. A. O. 


\section{Especialização produtiva regional: uma abordagem sobre o agronegócio da soja no Sul de Rondônia}

O Gráfico 4 faz um comparativo entre a produção estadual e a regional, como pode ser observado a área cultivada no estado em 1997 foi de 120.799 hectares para 185.413 em 2018 representando um aumento de $53,4 \%$ em duas décadas.

A área de 14.148 hectares da RPA de Vilhena correspondeu a $11,71 \%$ do total cultivado no estado com milho em 1997, chegando a 132.457 hectares em 2018 , sendo responsável por $71,43 \%$ da produção estadual.

O terceiro produto agrícola cultivado em Rondônia é o café. Muitos colonos que chegaram durante os projetos de colonização eram agricultores que trabalhavam nas lavouras de café no Sul e Sudeste do país, trazendo os conhecimentos culturais e aplicando em seus lotes. Assim como outros produtos agrícola, o café entrou em declínio nos anos 2000 com queda no preço fazendo com que muitos produtores desestimulassem da atividade e partissem para outra atividade. A produção do café usava o trabalho familiar, em muitas propriedades se ocupava da mão de obra de meeiros, parceiros, arrendatários, sendo essa liberada para outras atividades com a diminuição das lavouras cafeeiras substituídas em grande parte pelas pastagens plantadas.

A área cultivada de café na Região de Vilhena é pequena, ao comparar com a produção do estado se torna quase insignificante (gráfico 5). O maior pico de produção de café na Região de Vilhena foi no ano de 2001 com 2.130 hectares correspondendo a $0,95 \%$ da produção estadual que totalizou 222.926 hectares no mesmo período. A partir de 2001 o cultivo do café vai perdendo espaço em todo o estado, com leves reações de aumento que não se sustentam, fechando 2018 com 64.850 hectares, sendo uma queda acumulada de $71 \%$. A Região de Vilhena não é representativa no cultivo do café com 126 hectares ao comparar com a área de 64.850 hectares cultivada no estado. 


\section{Geografias de Rondônia Território, Fronteira e Educação}

Gráfico 5 - Produção de café em Rondônia e na RPA de Vilhena, de 1997 a 2018.

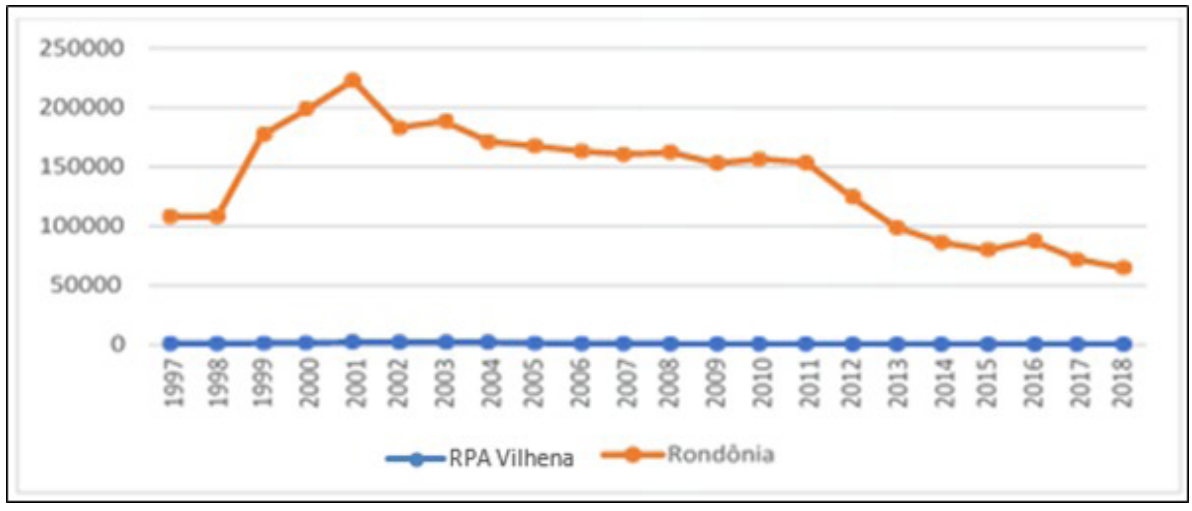

Fonte: IBGE/PAM, 2019. Organização: Souza, J. A. O.

O quarto produto agrícola é a soja, intensificou o cultivo a partir do ano de 1997 com a abertura da Hidrovia do Madeira. A Embrapa-RO intensificou as pesquisas para a Região de Vilhena e o eixo da BR-364, a partir do campo experimental de Vilhena e Porto Velho, com testes de cultivares desenvolvidas ao longo dos anos com variedades que melhor se ajuste a cada região. A área cultivada da oleaginosa passa a ser representativa a partir de 1998 com um total de 7,8 mil hectares, concentrada em Vilhena com 5.000 hectares e Cerejeiras 2.800 hectares, sendo quase 12 vezes superior ao ano de 1997 com 656 hectares,

Em Rondônia, a área plantada aumenta a cada safra, ocorrendo apenas um pico de declínio entre 2006 e 2007. O crescimento acumulado da área cultiva de 2008 a 2018 foi de $236 \%$, enquanto o crescimento acumulado na Região de Vilhena foi de $134 \%$. Esse crescimento no estado significa que a soja está se espacializando para outras regiões. No entanto, a região de Vilhena respondeu pela maior área cultivada no estado em 2018 com 2/3 da produção (Gráfico 6). 


\section{Especialização produtiva regional: uma abordagem sobre o agronegócio da soja no Sul de Rondônia}

Gráfico 6 - Produção de soja (hectares) em Rondônia e na RPA de Vilhena, safras de $1997 / 98$ a 2017/18.

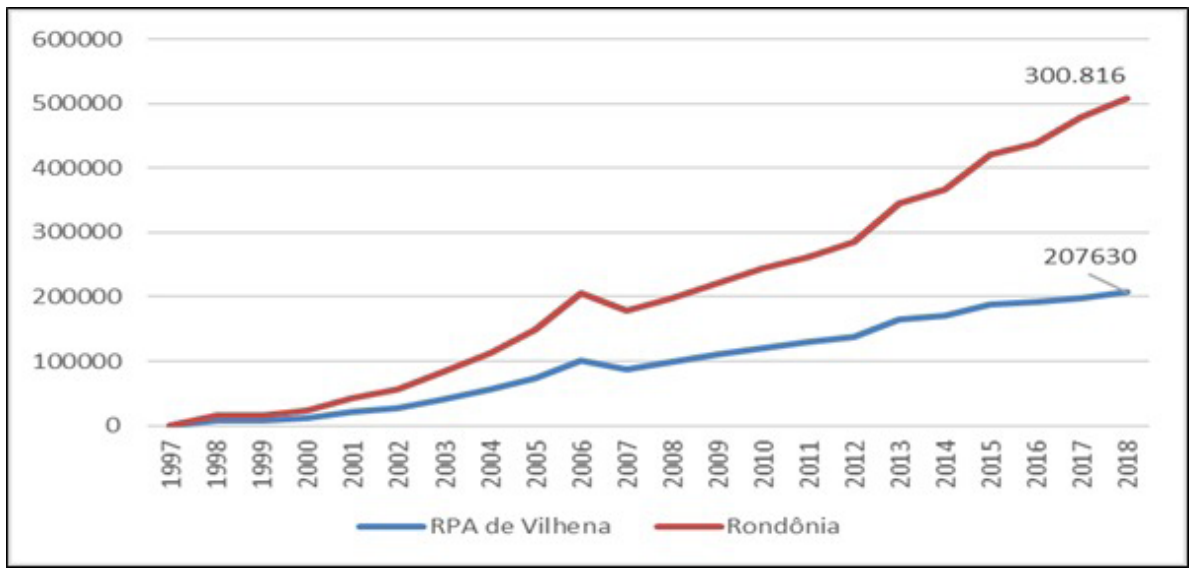

Fonte: IBGE/PAM, 2019. Organização: SOUZA, J. A. O.

Durante o período da colonização de Rondônia nas décadas de 1970 a 1980, conforme ocorria a distribuição dos lotes aos colonos, de imediato tomavam posse e começavam a derrubar a mata para construção de barracos e iniciar o cultivo da agricultura com arroz milho, feijão e café (Souza, et al., 2018). Com a derrubada da mata, a construção do barraco e roça, garantia a posse do lote e evitava invasores, tinham mantimentos com a cultura de subsistência e venda do excedente garantindo a sobrevivência. Era uma produção em pequena escala, no entanto, realizada por milhares de colonos espalhados pelo estado nos projetos de colonização.

À medida que o campo vai se modernizando, ocorre um aumento do número de máquinas e implementos agrícolas, dando maior robustez a produção em escala com commodities. Para ser mais competitivo o produtor rural reduz custos, o trabalho braçal é substituído por modernas máquinas e implementos que realizam o trabalho de dezenas de homens mantendo o mesmo padrão na produção de commodities. $\mathrm{O}$ campo rondoniense se mecaniza a cada ano, ao analisar a Figura 2, é possível observar uma espacialização dos tratores por município entre os anos de 2006 e 2017. Houve um aumento no número de tratores em relação ao ano de 2006, em todos os municípios. Os produtores rurais rondonienses acompanham a evolução do campo, investindo em máquinas agrícolas para melhorar a produção. 


\section{Geografias de Rondônia Território, Fronteira e Educação}

Figura 2 - Rondônia: número de tratores por município em 2006 e 2017.

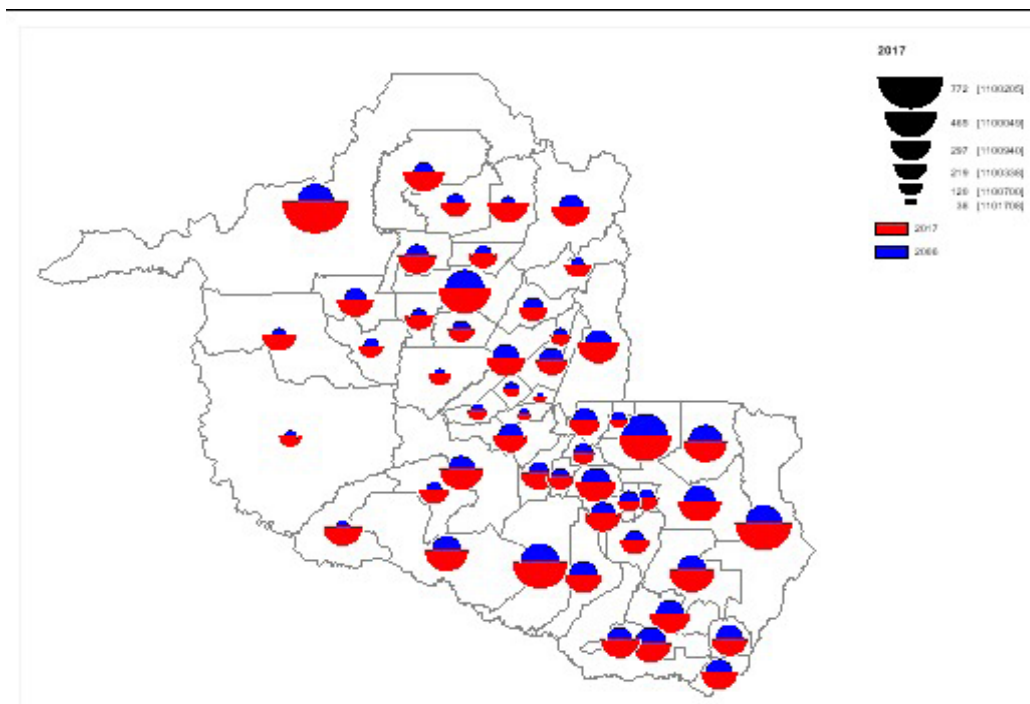

Fonte: IBGE/Sidra, 2017. Elaboração: SOUZA, J. A. O.

Fazendo um comparativo entre os anos de 2006 e 2017 para o número de tratores e propriedades com tratores, o crescimento da frota de tratores no estado em 2017 foi de $112,8 \%$, saindo de 5.772 para 12.283 unidades. No mesmo período ocorreu o aumento no número de estabelecimentos rurais que possuem tratores saindo de 4.617 para 8.907 estabelecimentos. O aumento do número de tratores está ligado ao crescimento do número de estabelecimentos agropecuários com as atividades agrícolas e pecuárias, já o aumento do número de colheitadeiras agrícolas está associado ao aumento da produção de grãos.

As máquinas de colher grãos multiplicaram, o estado contabilizava 377 unidades distribuídas em 304 estabelecimentos rurais em 2006. Em 2017 esse número subiu para 812 unidades de colheitadeiras em 490 estabelecimentos rurais, crescendo a uma proporção de $115,38 \%$ e $61,18 \%$. Alguns produtores rurais têm mais de uma propriedade ou arrendamento, e promove a movimentação das máquinas conforme necessidade de utilização. 


\section{Especialização produtiva regional: uma abordagem sobre o agronegócio da soja no Sul de Rondônia}

A Figura 3 mostra a distribuição das máquinas colheitadeiras de grãos concentradas no Sul do estado. Logicamente a RPA de Vilhena é responsável por $2 / 3$ da produção estadual de grãos concentrando $61 \%$ da frota.

Pode ser percebido uma espacialização da soja para a região norte do estado, com maior destaque para a região de Ariquemes e Porto Velho. Há um nítido crescimento das áreas de lavoura temporária nessas regiões, é possível ver que os produtores estão buscando a expansão das lavouras ou iniciando nova atividade agrícola com a produção de grãos. A expansão da produção de grãos e a mecanização do campo mexe com a mão de obra, que passa a ser cada vez menor e mais especializada para as atividades da agricultura moderna.

Figura 3 - Rondônia: número de colheitadeiras e distribuição por município entre 2006 e 2017.

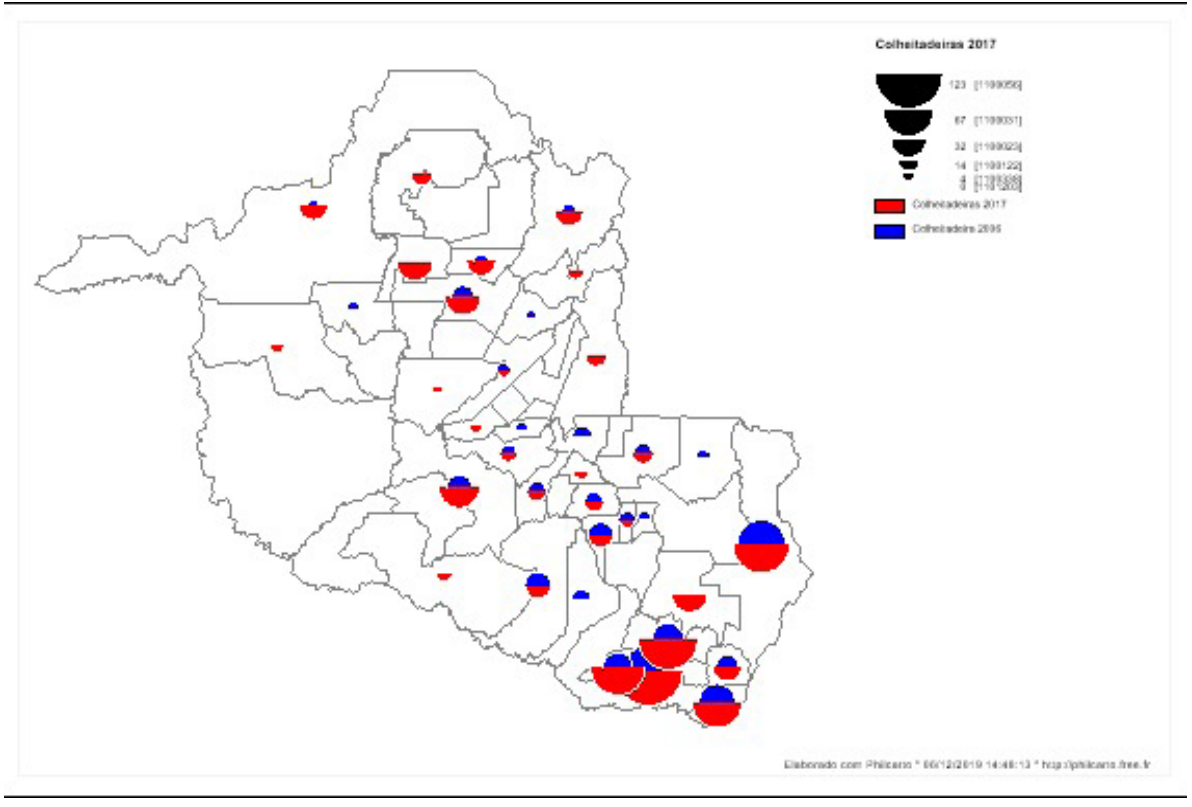

Fonte: IBGE/Sidra, 2017. Elaboração: J. A. O. Souza.

A Figura 4 traz a distribuição do pessoal ocupado nos estabelecimentos rurais rondonienses nas modalidades da pecuária, lavoura temporária e lavoura permanente. A agropecuária em suas diversas 


\section{Geografias de Rondônia Território, Fronteira e Educação}

modalidades emprega cerca de 270.812 pessoas em todo o estado de Rondônia, desse total a pecuária e criação de outros animais foi responsável por $78 \%$ dos empregos gerados no campo totalizando 211.381 postos de trabalho. Os demais empregos $(22 \%)$ são gerados pelas outras atividades, sendo observado para essa pesquisa a geração de empregos na pecuária, na lavoura temporária e permanente. A lavoura temporária empregou 18.317 pessoas e a lavoura permanente 31.656 pessoas, (Censoagro, 2017).

Figura 4 - Rondônia: pessoal ocupado na pecuária, agricultura permanente e temporária em 2017.

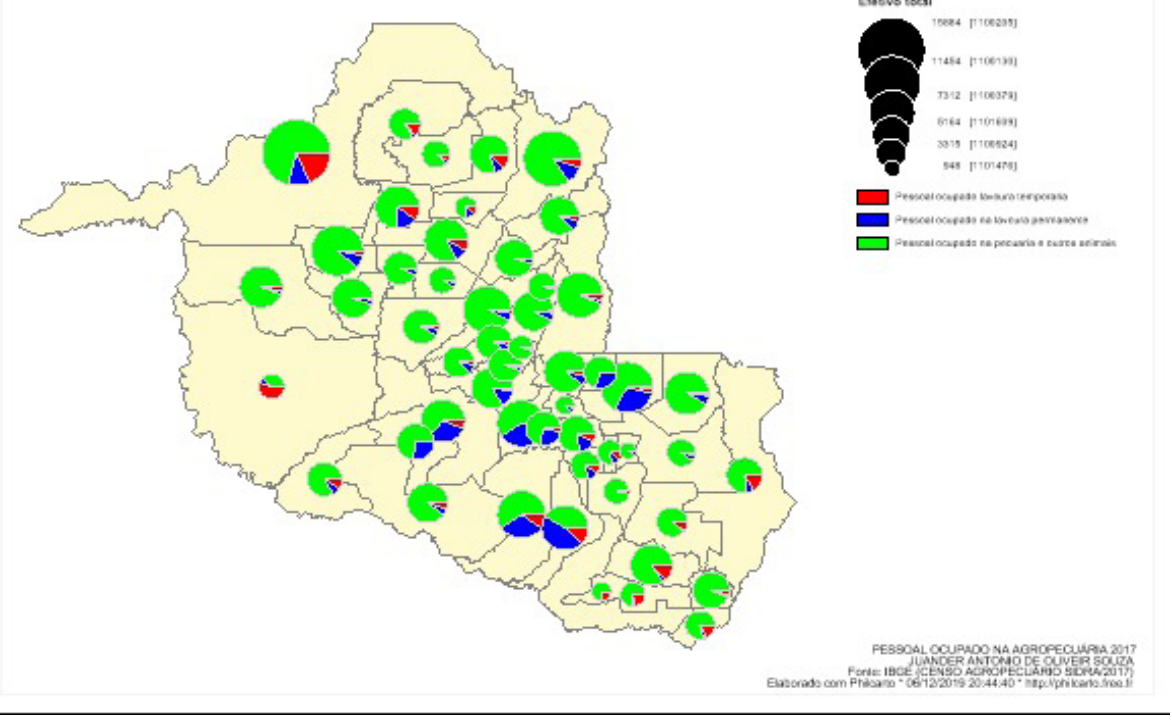

Fonte: IBGE/Sidra, 2017. Elaboração: J. A. O. Souza.

O único município que a pecuária não gera o maior quantitativo de mão de obra é em Guajará-Mirim, onde a produção da lavoura temporária gera 1.320 dos 2.780 empregos da agropecuária municipal.

A região central do estado apresenta a maior concentração da ocupação de mão de obra na lavoura permanente com os municípios de Alta Floresta D'Oeste, Cacoal, Nova Brasilândia, São Miguel do Guaporé, ambos com mais de 2 mil pessoas ocupadas e Alto Alegre 


\section{Especialização produtiva regional: uma abordagem sobre o agronegócio da soja no Sul de Rondônia}

dos Parecis liderando o ranking com 3.352 empregos em lavouras permanentes. Juntos esses cinco municípios são responsáveis por $42,93 \%$ da população ocupada nas lavouras permanentes. Esses municípios são produtores de café, e a lavoura cafeeira exige mão de obra. As propriedades são pequenas, geralmente da agricultura familiar e praticamente não se utiliza da mecanização agrícola para realizar a colheita e tratos culturais.

$\mathrm{Na}$ Região de Vilhena, a maior quantidade de pessoas ocupadas no campo está na pecuária, seguida da produção de lavoura temporária. A mão de obra empregada na lavoura permanente é quase inexistente, apenas o município de Vilhena é o mais representativo da região com 323 postos de trabalho. O pessoal ocupado na região corresponde $9,47 \%$ do estado, equivale a 24.957 pessoas do pessoal ocupado no campo rondoniense, estratificando tem-se 20.755 pessoas empregadas na pecuária, 829 pessoas na produção de lavouras permanentes, 3.373 na produção de lavouras temporárias.

Pode concluir que a agricultura moderna não é grande geradora de mão de obra, principalmente para a lavoura temporária com a produção em larga escala, visto que a maior região produtora de grãos do estado emprega apenas $18,41 \%$ da população ocupada do estado na atividade das lavouras temporárias. A agricultura moderna substitui o esforço humano pelo esforço mecânico através das máquinas e implementos agrícolas operados por trabalhadores qualificados que invadem o espaço agrícola a partir dos avanços tecnológicos necessitando cada vez menos do elemento humano. Na Região de Vilhena, a mecanização do campo aumenta a cada nova safra com a produção de grãos e a introdução de mais máquinas agrícolas, já a atividade pecuária necessita do homem para manejo dos bovinos, manutenção de cercas, pastagens, atividade leiteira, coisas que a tecnologia ainda não domina no campo ou tecnologias pouco acessíveis.

\section{RPA DE VILHENA E A CIDADE DO AGRONEGÓCIO}

Vilhena apresentou um crescimento no número de empresas desde a década de 1980 com a abertura de novas empresas. Nos últimos dez anos, apresentou um maior aumento na abertura de empresas, como pode ser observado no Gráfico 7, na série histórica da abertura de empresas no município. 


\section{Geografias de Rondônia Território, Fronteira e Educação}

O ano de 2017 apresentou o maior número de abertura de empresas totalizando 1.097, no entanto, em 2018 ocorreu uma redução $47,67 \%$ totalizando 574 empresas abertas. Esse desaquecimento de abertura de empresas foi proveniente da situação política que o país passava após o impeachment da presidente Dilma Rousseff, assumindo seu vice Michael Temer, sendo que 2018 foi ano eleitoral, o que fez gerar uma incerteza no mercado influenciando negativamente na abertura de empresas em razão das propostas dos possíveis candidatos para a condução do país e políticas de desenvolvimento.

Gráfico 7 - Abertura de empresas por ano no município de Vilhena, 1980 a 2018.

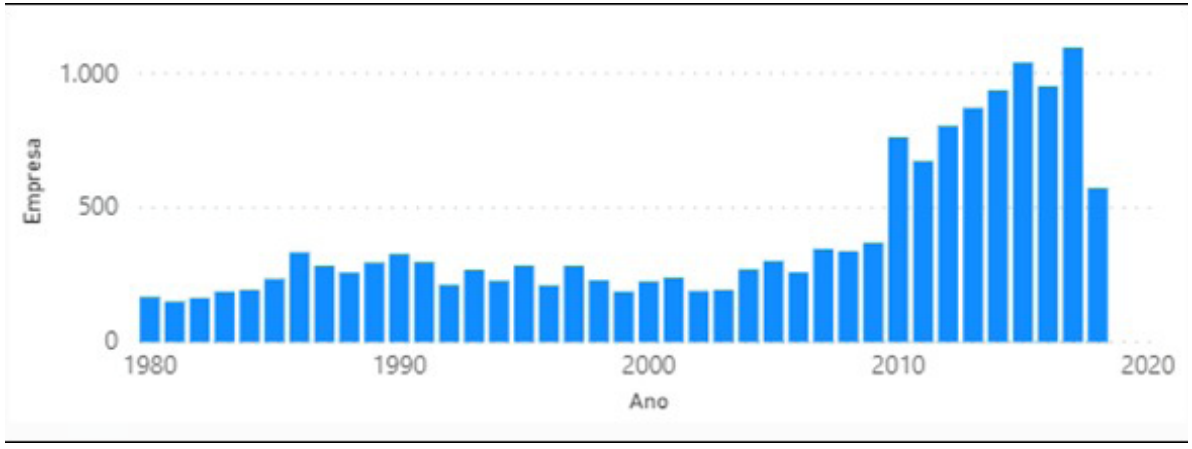

Fonte: Jucer, 2019.

De acordo com a Junta Comercial do Estado de Rondônia - Jucer, o estado fechou o ano de 2019 com 132.159 empresas com cadastro ativo, e o município de Vilhena comporta $7,18 \%$ desse total perfazendo 9.493 empresas. Das empresas rondonienses com cadastro ativo, apenas 55.440 unidades empregaram trabalhadores formais em 2019 gerando 235.172 vagas de emprego, em Vilhena são 4.475 empresas empregando 18.303 trabalhadores correspondendo a $7,78 \%$ dos empregos formais das empresas rondonienses (Jucer, 2019). Nem todas as empresas com registro ativo geram empregos formais. 


\section{Especialização produtiva regional: uma abordagem sobre o agronegócio da soja no Sul de Rondônia}

Gráfico 8 - Vilhena: empresas do ramo Agropecuário ativa e abertura por ano, 1980 a 2019.

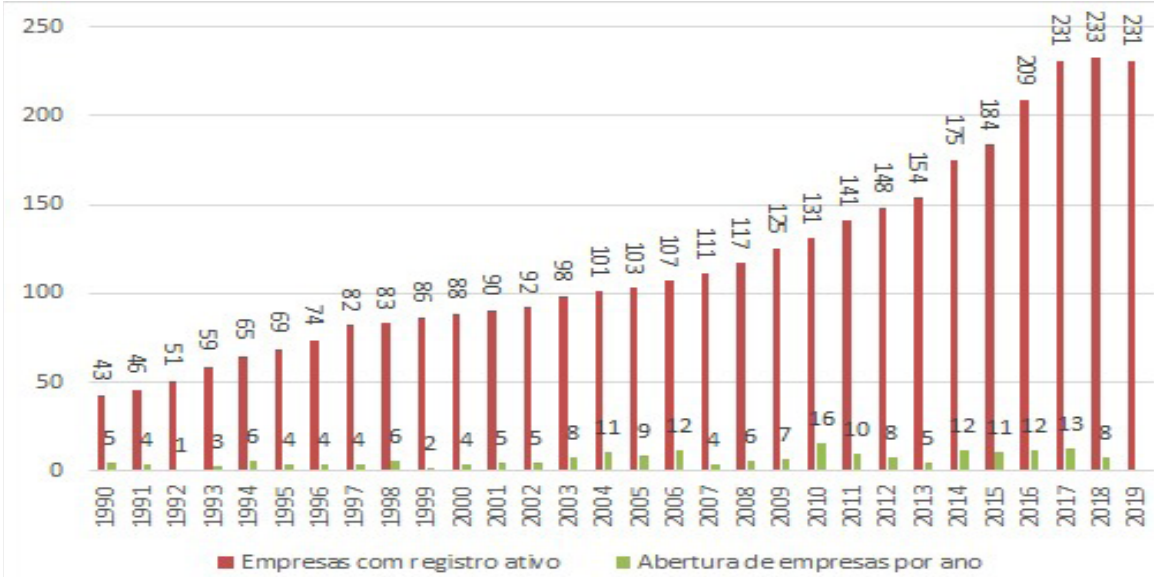

Fonte: Jucer, 2019. Organização: SOUZA, J. A. O.

Em 2019, Vilhena apresentou um total de 231 estabelecimentos do ramo agropecuário com cadastro ativo, conforme Gráfico 8, já com relação à abertura de novas empresas, a partir de 2014 teve um crescimento constante mais acentuado até 2017 ficando estabilizado até o ano de 2018. A abertura das empresas do ramo agropecuário sempre foi crescente, acompanhando a evolução das atividades agrícolas e pecuárias.

O Gráfico 9 mostra a estratificação das 231 empresas do ramo de atividades agropecuárias no município de Vilhena no ano de 2019, divididas em diversos ramos da atividade agropecuária.

Com relação às empresas ligadas ao cultivo das lavouras temporárias, Vilhena possui 20 estabelecimentos comerciais específicos para o cultivo da soja e 20 para o cultivo do milho, esses dois produtos agrícolas predominam na região. O município conta com 25 empresas com atividade de pós colheita e 26 empresas com atividades de preparação do solo para lavouras, contando com 14 estabelecimentos comerciais que realizam atividades de pulverização e controle de pragas na lavoura de grãos. 


\section{Geografias de Rondônia Território, Fronteira e Educação}

Gráfico 9 - Vilhena: principais atividades do ramo da agropecuária e total de empresas em 2019.

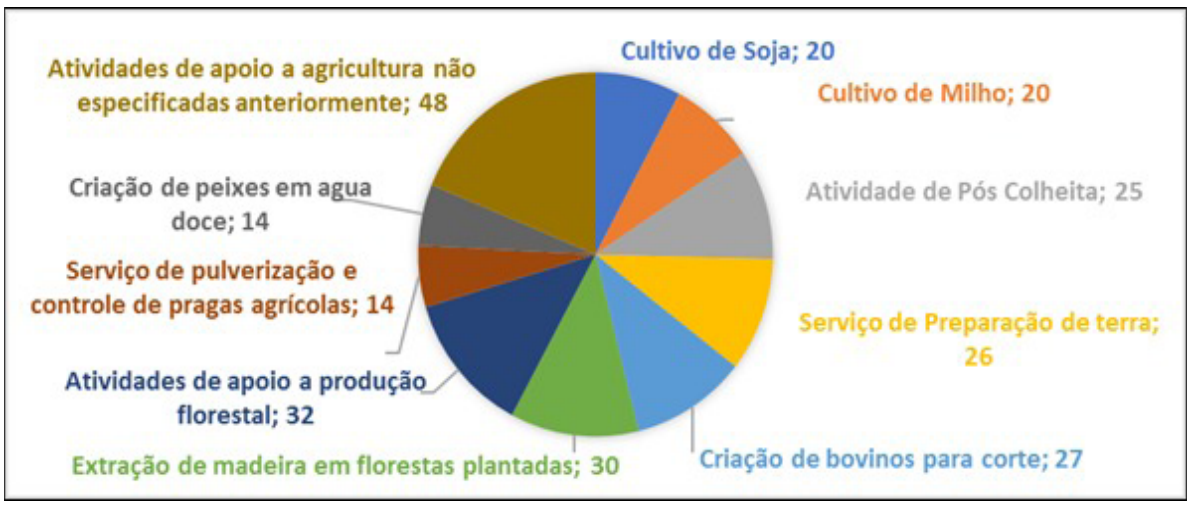

Fonte: Pesquisa de Campo, 2019. Organização: SOUZA, J. A. O.

Alguns produtores podem simplesmente contratar o serviço de controle de pragas, caso não queira investir na compra de um pulverizador autopropelido ou uma colheitadeira de grãos, que imobiliza grande quantidade de dinheiro, recorrendo à oferta desses e outros serviços. $\mathrm{O}$ produtor pode investir no cultivo de grãos mesmo sem equipamentos, porém, deve se levar em conta os custos com serviços e o rendimento médio por hectare para analisar se é vantajoso realizar o investimento.

Para a atividade pecuária, Vilhena conta com 27 estabelecimentos comerciais diversos, desde casas de agropecuária a venda de embriões, escritórios que prestam consultoria rural e demais serviços como análise de solo, projetos de financiamentos, etc. Muitas empresas prestadoras de serviço, atendem a agropecuária de acordo com o interesse do produtor ao procurar o serviço desejado.

Vilhena possui uma unidade frigorífica do Grupo JBS, com abate diário de 800 animais, e emprega cerca de 1.219 funcionários (Marques, 2017). Esse frigorífico exporta carne para outros estados e países, e em 2019 foi habilitado pela China para exportar carne bovina aos países asiáticos (Negócios, 2019; Marques, 2017). Realiza a compra de bovinos dos produtores da Região de Vilhena e demais municípios circunvizinhos.

Para atender as demandas com pessoal qualificado com cursos técnicos profissionalizantes, graduação e pós-graduação, Vilhena conta 


\section{Especialização produtiva regional: uma abordagem sobre o agronegócio da soja no Sul de Rondônia}

com 14 instituições de ensino superior com cursos de graduação nas modalidades presenciais, semipresenciais e educação a distância, se destaque por oferecer um dos cinco ursos de medicina do estado. Essas instituições oferecem cursos de bacharelado e licenciatura nas áreas de ciências exatas e da terra, ciências humanas, ciências biológicas, ciências agrárias, engenharias e ciências sociais. Além de contar com 12 instituições que oferecem cursos profissionalizantes e de nível técnico reconhecido, formando profissionais para atender as demandas da região e do estado (Jucer, 2019; Pesquisa de campo, 2020).

$\mathrm{Na}$ área da saúde e serviços sociais, Vilhena conta com 193 estabelecimentos. Destes 186 estabelecimentos são de atividades de atenção à saúde humana, sendo 34 unidades de atendimento hospitalar; 24 unidades de serviços móveis de atendimento a urgência e de remoção de pacientes; 126 estabelecimentos de atividade de atenção ambulatorial executado por médicos e odontólogos; 66 estabelecimentos de atividades de serviços de complementação diagnóstica e terapêutica; 55 estabelecimentos de profissionais da área da saúde; 34 estabelecimentos de atividades de atenção à saúde humana integrados com assistência social, prestado em residências coletivas e particulares (Jucer, 2019). Alguns estabelecimentos desenvolvem várias atividades/ou especialidades sendo verdadeiros centros de saúde humana com atividades laboratoriais, realização de diversos exames, radiografias, etc., assistência psicológica, dentre outras atividades da área da saúde, encontrando no município diversos serviços que são oferecidos nos grandes centros urbanos.

No quesito de instituições financeiras Vilhena está bem guarnecida, com nove bancos comerciais, nove cooperativas de crédito mútuo; nove cooperativas de crédito rural; 40 holdings não financeiras; duas agências da Caixa Econômica; três bancos múltiplos com carteira comercial; quatro sociedades de fomento mercantil (Jucer, 2019). Os moradores da RPA de Vilhena e oeste mato-grossense, encontram em Vilhena suporte a produção agrícola desde o financiamento de lavouras, máquinas, equipamentos, crédito para custear a produção, compra de veículos, com possibilidade de escolha da instituição financeira que oferece melhor taxa de juros. Não sendo necessário se deslocar aos grandes centros como a capital porto-velhense para tratar das situações financeiras, encontrando em Vilhena as principais agências bancárias.

$\mathrm{Na}$ área comercial, na região central da cidade de Vilhena é possível encontrar diversos prédios de dois e três pisos, devido à grande concentração do comércio e valorização do metro quadro. Essa concentra- 


\section{Geografias de Rondônia Território, Fronteira e Educação}

ção fez ocorrer um crescimento vertical da arquitetura da cidade, devido à supervalorização da área comercial e interesse dos comerciantes.

A urbanização ocorre tanto verticalmente, com a construção de prédios nas áreas mais valorizadas como horizontalmente, com a abertura de loteamentos e condomínios fechados. O menor preço de um terreno de $364 \mathrm{~m}^{2}$ no Condomínio Boulevard Premium é de $\mathrm{R} \$ 130.000,00$ reais (MFG Imóveis, 2020), e nas suas adjacências encontram-se terrenos de $240 \mathrm{~m}^{2}$ a partir de $\mathrm{R} \$ 39.000,00 \mathrm{com}$ toda a infraestrutura (Areval Imóveis, 2020). Pode ser percebido que o condomínio Boulevard é para uma clientela que possuir maior poder aquisitivo.

Fora as agências financeiras localizadas no centro comercial, as concessionárias de veículos automotores (Chevrolet, Ford, Fiat, Hyundai, Mitsubishi, Toyota), e de máquinas e implementos agrícolas (exemplo Case, Agralle, John Deere, New Holland, Massey Ferguson, Valtra), trabalham com seus próprios bancos, oferecendo esse serviço na hora da compra, possibilitando escolha de uma menor taxa de juros pelas várias opções.

Figura 5 - Pulverizador autopropelido da New Holland exposto no canteiro central.

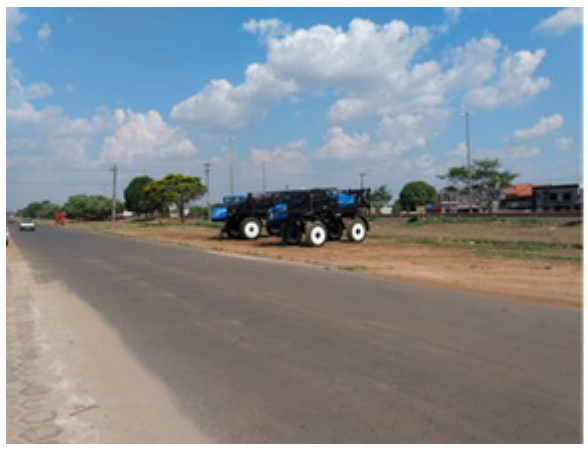

Fonte: Pesquisa de Campo, 2020.
Figura 6 - Concessionaria da New Holland as margens da BR-364.

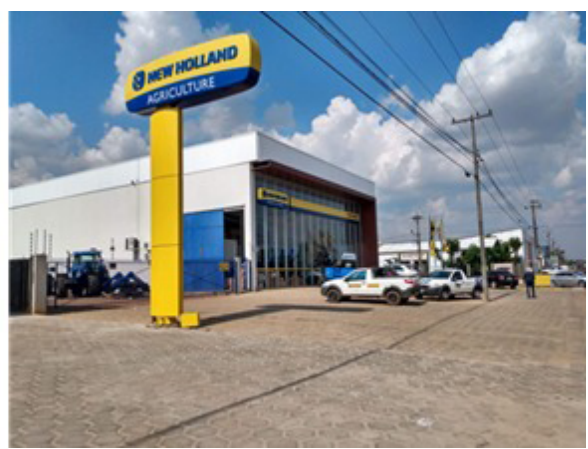

Fonte: Pesquisa de Campo, 2020.

As revendas de máquinas e implementos agrícolas estão localizadas as margens da BR-364 com os produtos expostos no pátio e na calçada das lojas dando maior visibilidade ao cliente chamando a atenção de quem passa pela BR-364 ou na via marginal, como a exposição do pulverizador autopropelido no canteiro que divide a BR-364 e a via 


\section{Especialização produtiva regional: uma abordagem sobre o agronegócio da soja no Sul de Rondônia}

marginal (Figura 5), tendo a loja de revenda da New Holland próxima ao Pulverizador (Figura 6).

As margens da BR-364 ao longo do perímetro urbano, encontra-se as principais empresas ligadas a agropecuária, comércio de veículos, peças de veículos, lojas de autopeças para linhas leves e pesadas, prestação de serviços a veículos automotores, caminhões, máquinas e implementos agrícolas, oficinas de motocicletas, 16 postos de combustíveis, etc.

Acompanhando o crescimento populacional da cidade e do comércio, ocorreu o crescimento dos hotéis e similares, que em três décadas multiplicou por oito vezes, em 1990 era apenas nove estabelecimentos, e em 2018 foram registrados 76 estabelecimentos. Esses hotéis abrigam pessoas que vem trabalhar na cidade em períodos esporádicos, seja safra, entressafra, vendedores, prestadores de serviços ligados ao agronegócio ou não, prestadores de serviços na área da saúde, dentre tantas outras atividades que nem sempre estão ligadas ao agronegócio, mas que movimenta e impulsiona a economia da cidade.

Em Vilhena encontra-se instaladas empresas como a Gazin Fábrica de Colchões (cama box, e estofados); comércio varejista com lojas da Havan; Lojas Americanas; fast food como o Bob's e o Subway; Portal Óleos Esmagadora de Grãos de soja; Zoche Baterias (produção de baterias automotivas); Rical Indústria de Alimentos, dentre outras.

Acompanhando o crescimento urbano, investidores abriram o primeiro shopping da região "Park Shopping Vilhena", inaugurado em setembro de 2010, empregando cerca de 250 pessoas (Semma, 2010). Em maio de 2015 o Park Shopping Vilhena sofreu um incêndio, sendo reinaugurado em dezembro de 2015 (Extra de Rondônia, 2015), atualmente emprega mais de 500 pessoas e é considerado um dos pontos de encontro da cidade contando com diversas lojas (Weber, 2015).

A comunicação local de Vilhena fica por conta das emissoras de rádio e TV, sendo cinco emissoras de rádio e seis emissoras de televisão. Possui dois jornais impressos, além de dez jornais online. Mediante os canais de comunicação, mantém a população vilhenense bem informada, seja por meio da TV, pelo rádio, ou pelos jornais online, podendo ser acessado a qualquer momento e qualquer lugar a partir de um smartfone.

Para deslocamento mais rápido ou emergências, o município possui um aeroporto que recebe voos civis e militares podendo receber voos de grandes aeronaves. $\mathrm{O}$ aeroporto recebe voos comerciais regulares diário. De janeiro a novembro de 2019 o aeroporto movimentou 35.860 passageiros entre pousos e decolagens em voos regulares e não regula- 


\section{Geografias de Rondônia Território, Fronteira e Educação}

res. Esse aeroporto serve a todos os municípios da Região de Vilhena e noroeste do Mato Grosso, o que possibilita esse fluxo de passageiros. $\mathrm{Na}$ região central do estado o município de Cacoal possui aeroporto com voos regulares, atendendo os municípios circunvizinhos.

A cidade de Vilhena se (re)estruturou para atender as demandas do agronegócio, seja no campo, seja na cidade, com dezenas de empresas de pequeno e grande porte para dar suporte diretamente ou indiretamente a produção agrícola, promoveu o crescimento urbano da cidade e da população, atraindo cada vez mais investimentos, pessoas das cidades vizinhas e do campo que buscam melhores condições de trabalho no município devido ao êxodo rural e a mecanização agrícola.

\section{CONSIDERAÇÕES FINAIS}

O agronegócio se especializou da região oeste mato-grossense para o Sul de Rondônia consolidando a soja na região de Vilhena formando uma RPA, transformando o município de Vilhena em uma cidade do agronegócio, adaptada para atender a demanda da produção de grãos. A RPA de Vilhena é responsável por $2 / 3$ da produção de grão em Rondônia, e exportação de produtos básicos no ano de 2019 foi composta de $46 \%$ da pecuária e $30 \%$ de soja, demonstrando a importância do agronegócio para a balança comercial estadual.

A RPA de Vilhena promoveu uma reestruturação da cidade e do campo. Como cidade do agronegócio, Vilhena concentra 231 empresas do ramo agropecuário, fornecendo todo o tipo de insumos e serviços utilizados para a produção de grãos na região, com empresas especializadas em determinadas atividades agrícolas, com produtos e serviços encontrados em outras regiões tradicionais produtoras de grãos no sul e sudeste do país. Tem empresas hegemônicas como a Bunge, Cargill, Grupo Amaggi, dentre dezenas de outras empresas de grande porte com filiais em Vilhena atendendo os seguimentos do agronegócio.

O agronegócio trouxe divisas para o estado e para Vilhena, no entanto, gera desigualdades sociais, promove o êxodo rural, e uma migração campo-cidade, com a maioria dos municípios perdendo população principalmente pelo êxodo rural proveniente do agronegócio que emprega pouca mão de obra devido à mecanização agrícola. Os camponeses migram para as cidades ou outras regiões onde a fronteira agrícola ainda não está consolidada buscando melhores condições. Há evidências 


\section{Especialização produtiva regional: uma abordagem sobre o agronegócio da soja no Sul de Rondônia}

empíricas de que o agronegócio é gerador de desigualdades e concentrador de riquezas.

Internamente a soja ainda se encontra em fase de expansão pela RPA de Vilhena e por todo o estado, apresentando uma mudança mais acentuada nos municípios componentes da RPA de Vilhena, porém, ocorre a espacialização para as outras regiões do estado conforme a distribuição de máquinas agrícolas. A soja é a continuidade das várias formas de processos de ocupação.

\section{REFERÊNCIAS}

AREVAL IMÓVEIS. 2020. Disponível em: www.arevalimoveis.com.br/ imoveis/a-venda/terreno/vilhena/condominio. Acesso em: 14 jan. 2020.

ARROYO, M. El territorio brasileño y la internacionalización de los circuitos de producción. In: BERTONCELLO, R.; CARLOS, A.F.A. (Orgs.). Procesos territoriales en Argentina y Brasil. Buenos Aires: Instituto de Geografía, Facultad de Filosofía y Letras-UBA, 2003a. p. 315-336.

BARBOSA, I.G. Um estudo de percepção ambiental em Sapezal, Mato Grosso: elos para a Educação Ambiental. Dissertação de Mestrado. Universidade Estadual de Mato Grosso. Programa de Pós-Graduação em Ciências Ambientais, 2011. Disponível em: http://portal.unemat.br/ media/oldfiles/ppgca/docs/dissertacao_ilma_grisote.pdf. Acesso em: 21 jul. 2020.

BERNARDES, J.A. Fronteiras da agricultura moderna no cerrado norte/ nordeste: descontinuidades e permanências. In: BERNARDES, J.A; BRANDÃO FILHO, J.B. (Org). Geografias da Soja II: a territorialidade do Capital. Rio de Janeiro. Arquimedes edições/CNPq, 2009. p. 13-39.

BERNARDES, J.A.; ARACRI, L.A.S. Espaço e circuitos produtivos: a cadeia carne/grãos no cerrado mato-grossense. Rio de Janeiro: Arquimedes, 2010.

CASTILLO, R. et al. Regiões do agronegócio, novas relações campo cidade e reestruturação urbana. Revista da Associação Nacional de PósGraduação e Pesquisa em Geografia (Anpege), v. 12, n. 18, 2016. p. 265 288. Disponível em: www.repositorio.ufc.br/handle/riufc/24490. Acesso em: 22 jul. 2020.

CPT. Comissão Pastoral da Terra. Conflitos no Campo - Brasil 2018. Goiânia: CPT Nacional - Brasil, 2019. 


\section{Geografias de Rondônia Território, Fronteira e Educação}

COSTA SILVA, R.G.A regionalização do agronegócio da soja em Rondônia. Geousp - Espaço e Tempo (online), São Paulo, v. 18, n. 2, p. 298-312, 2014a. Disponível em: www.revistas.usp.br/Geousp/article/view/84534\#: :text=No\%20sul\%20de $\% 20$ Rond $\%$ C3\%B4nia $\% 20$ tem,pelas $\% 20$ empresas $\% 20$ hegem $\%$ C3\%B4nicas $\% 20 \mathrm{do} \% 20$ agroneg\% C3\%B3cio. Acesso em: 10 jul. 2020.

COSTA SILVA, R.G. Avanços dos espaços da globalização: a produção de soja em Rondônia. Dissertação (Mestrado em Desenvolvimento Regional e Meio Ambiente) - Universidade Federal de Rondônia, Porto Velho, 2005.

COSTA SILVA, R.G. Rondônia, espaço de grandes transformações. Confins, n. 29, 2016. Disponível em: https://journals.openedition.org/ confins/11538. Acesso em: 15 maio 2019.

COSTA SILVA, R.G.C. Globalização e fragmentação do espaço agrário em Rondônia. Revista de Desenvolvimento Econômico, v. XVI, p. 163174, 2014. Disponível em: https://revistas.unifacs.br/index.php/rde/article/view/3610. Acesso em: 5 jun. 2020.

CUNHA, S.R.P. O xadrez da terra: um estudo da colonização em Rondônia. Belém, NAEA, 1985.

ELIAS, D. Agronegócio e novas regionalizações no Brasil. Revista Brasileira de Estudos Urbanos e Regionais, v. 13, n. 2, p. 153-167, 2011. Disponível em: https://rbeur.anpur.org.br/rbeur/article/view/400. Acesso em: 10 jun. 2020.

ELIAS, D. Regiões produtivas do agronegócio: notas teóricas e metodológicas. In: BERNARDES, J. SILVA, C.A. ARRUZZO, R.C. Espaço e energia: mudanças no paradigma sucroenergético. Rio de Janeiro: Lamparina, 2013, p. 201-220.

EXTRA DE RONDÔNIA. Veja imagens de lojas que vão inaugurar no Park Shopping Vilhena. 2015. Disponível em: www.extradeRONDÔNIA.com.br/2015/12/18/veja-imagens-de-lojas-que-vao-inaugurar-no-park-shopping-vilhena/. Acesso em: 14 jan. 2020.

EXTRA DE RONDÔNIA. Vilhena completa 40 anos de emancipação: conheça um pouco mais sobre sua história e de seus pioneiros. 2017. Disponível em: www.extradeRONDÔNIA.com.br/2017/11/21/vilhena-completa-40-anos-de-emancipacao-conheca-um-pouco-mais-sobre-sua-historia-e-de-seus-pioneiros/. Acesso em: 8 ago. 2019.

FONSECA, S.G. Memórias do massacre de Corumbiara: a luta pelo direito à função social da terra. (1995). Porto Alegre: Pontifícia Universidade Católica do Rio Grande do Sul, 2015, Dissertação de 


\section{Especialização produtiva regional: uma abordagem sobre o agronegócio da soja no Sul de Rondônia}

Mestrado da Faculdade de Filosofia e Ciências Humanas, Pós-Graduação em História, PUCRS.

IBGE/SIDRA. 2017. Indicadores de desenvolvimento sustentável. 2017. Disponível em: https://sidra.ibge.gov.br/tabela/896. Acesso em: 2 dez. 2019.

IBGE. Estatísticas econômicas. 2019. Disponível em: www.ibge.gov.br/ estatisticas/economicas/contas-nacionais/9088-produto-interno-bruto-dos-municipios.html?t=series-historicas\&c=1100304. Acesso em: 2 dez. 2019.

IBGE. Censo agropecuário 2017. Disponível em: https://censoagro2017. ibge.gov.br/. Acesso em: 18 maio 2019.

IBGE. Pesquisa agropecuária municipal, área de produção de soja. 2019. Disponível em: https://sidra.ibge.gov.br/tabela/188\#resultado. Acesso em: 15 maio 2019.

IBGE. Censo demográfico 2010, Sidra, 2019. Disponível em: https:// censo2010.ibge.gov.br/resultados.html. Acesso em: 3 dez. 2019.

Idaron. Relatório de vacinação de abril a maio/2018. Documento. Porto Velho, Idaron, 2018. Disponível em: www.idaron.ro.gov.br/index.php/ relatorios-e-formularios/. Acesso em: 7 dez. 2018.

Jucer. 2019. Disponível em: www.odr.ro.gov.br/c/Jucer/5b29fc90-e9f4e911-80ef-005056312ed4. Acesso em: 13 jan. 2020.

MARQUES, E. Autoridades realizam visita técnica em frigorífico da JBS em Vilhena, RO. 2017. Disponível em: https://g1.globo.com/ro/vilhena-e-cone-sul/noticia/autoridades-realizam-visita-tecnica-no-frigorifico-da-jbs-em-vilhena-ro.ghtml. Acesso em: 9 jan. 2020.

MARTINS, M.M. Corumbiara: massacre ou combate? A luta pela terra na fazenda Santa Elina e seus desdobramentos. Dissertação de mestrado. Porto Velho: Universidade Federal de Rondônia, Programa de Pósgraduação em Geografia, 2009.

MFG IMÓVEIS. 2020. Disponível em: https://ro.mgfimoveis.com.br/ terreno-condominio-boulevard-premium-venda-ro-vilhena-205998530. Acesso em: 14 jan. 2020.

NEGÓCIOS. JBS e Seara possuem plantas entre as aprovadas para exportação de carne à China. 2019. Disponível em: https://epocanegocios.globo.com/Empresa/noticia/2019/11/epoca-negocios-jbs-e-seara-possuem-plantas-entre-as-aprovadas-para-exportacao-de-carne-a-china.html. Acesso em: 9 jan. 2020. 
NEVES; M.F. Cadeias e redes de empresas como instrumento para o desenvolvimento. In: NEVES, M.F. ZYLBERSZTAJN, D. NEVES, E.M. Agronegócio do Brasil. São Paulo: Saraiva, 2005. p. 32-35.

RICARTE, C.A.A. A psicosfera do espaço agrário de Vilhena: contradições entre o agronegócio e o campesinato. Dissertação de Mestrado apresentada no Programa de Pós-Graduação em Geografia na Universidade Federal de Rondônia. Rondônia UNIR, 2017.167p. Disponível em: www. posgeografia.unir.br/uploads/99999999/dissertacoes/MESTRADO/ TURMA\%202015-1/DISSERTACAO\%20-\%20Carlos.pdf. Acesso em: 10 maio 2020.

SANTOS, M. O trabalho do geógrafo no terceiro mundo. São Paulo: Hucitec, 1978.

SANTOS, M. A natureza do espaço: técnica e tempo, razão e emoção. São Paulo: Haucitec, 1996.

SANTOS, M. [2000]. Por uma outra globalização: do pensamento único à consciência universal. 16 ed. Rio de Janeiro, Record, 2008.

SANTOS, M. (1988). Metamorfoses do espaço habitado: fundamentos teóricos e metodológicos da Geografia. 6. ed. São Paulo: Edusp, 2014. 136p (Coleção Milton Santos, 10).

SANTOS, C.D. Difusão do agronegócio e região: a RPA de Barreiras. Anais. XI Encontro da Associação Nacional de Pós-Graduação e Pesquisa em Geografia. Presidente Prudente, 2015. Disponível em: www. enanpege.ggf.br/2015/anais/. Acesso em: 15 maio 2019.

SEMMA. Primeiro shopping de Vilhena é inaugurado. 2010. Disponível em: www.semma.com.br/primeiro-shopping-de-vilhena-e-inaugurado/. Acesso em: 14 jan. 2020.

SOUZA, J.A.O.; XIMENES, C.C.; LOCATELLI, M. Rondônia, a colonização que deu certo. In: Embrapa Rondônia-Artigo em anais de congresso (Alice). Trabalho apresentado nos Anais do X Seminário Temático da Rede Internacional Casla-Cepial: Conhecimentos Etnocientíficos e Territorialidades Alternativas; XIII Encontro de Pós-Graduação em Geografia; II Encontro diálogos de saberes e conhecimentos tradicionais em Rondônia, 2018. 2018. Disponível em: www.even3.com.br/anais/ cepialro2018/81037-RONDÔNIA-a-colonizacao-que-deu-certo/. Acesso em: 15 maio 2019.

WEBER, D. Shopping de Vilhena, RO, é atingido por incêndio e tem área destruída. 2015. Disponível em: http://g1.globo.com/ro/RONDÔNIA/ noticia/2015/05/parte-de-shopping-em-vilhena-ro-e-destruida-apos-incendio.html. Acesso em: 14 jan. 2020. 


\title{
TERRITORIALIZAÇÃO, EXPANSÃO E CONTRADIÇÕES DO AGRONEGÓCIO NO ESPAÇO AGRÁRIO DE RONDÔNIA
}

\author{
Carlos Alberto de Almeida Ricarte*
}

\section{INTRODUÇÃO}

A fronteira com o estado do Mato Grosso instigou a migração de sulistas para o sul de Rondônia proporcionando a espacialização das commodities agrícolas em escala comercial. Motivados pelo preço da terra e pelos incentivos financeiros públicos/privados, grandes empreendimentos agrícolas se territorializaram sobretudo no município de Vilhena, que passou a exercer forte influência regional dado o aporte técnico-operacional necessário à proliferação da monocultura de grãos no sul do estado, nos meados da década de 1990.

Concomitante a esse processo, revelam-se as transformações impostas e induzidas ao espaço rural/urbano dos municípios do cone sul de Rondônia que aderiram a esse modelo de produção. Impactos sociais e ambientais se tornaram uma constante à medida que empresas (tradings) agropecuárias passaram a exercer forte controle da produção e do comércio desses produtos. A lógica corporativa do agronegócio que se delineia sobre o território rondoniense cria novos arranjos espaciais e instaura novas relações socioespaciais revelando a complexa integração do local aos mercados globais, ocasionando a exclusão e desigualdades no campo. Dessa forma, a violência no campo cresce na proporção em que se expande a agropecuária. A demanda por terras em Rondônia, abre caminhos para a prática da grilagem e, consequentemente, para a concentração fundiária no estado.

As invasões às Terras Indígenas (TIs) e às Unidades de Conservação (UCs) põe em risco o modo de vida dos povos tradicionais, cuja sobrevivência, depende exclusivamente da natureza para manter seus laços socioculturais.

"https://orcid.org/0000-0002-8141-4250 


\section{Geografias de Rondônia Território, Fronteira e Educação}

$\mathrm{Na}$ fronteira corporativa de Rondônia, nos empreendimentos agropecuários prevalece a lógica capitalista de produção, a terra de negócio, em detrimento do território do campesinato, dos ribeirinhos, dos quilombolas e dos indígenas, cuja produção é destinada, essencialmente, à subsistência.

A natureza desse estudo tem como objetivo compreender a mudança na organização de ordem espacial, social, econômica e ambiental e a crescente evolução na produção de commodities em Rondônia. Com o apoio do Estado, novos sistemas de ações e sistemas de objetos colocaram Rondônia no circuito espacial de economia globalizada.

Essa pesquisa possui uma abordagem quali-quantitativa. Os principais aportes teórico-conceituais se fundamentam em: Santos (2008); Corrêa (2019); Haesbeart (2014); Moreira (2015); Becker (2007); Henry (2012); e Costa Silva (2014; 2018), entre outros.

Foram utilizados como procedimentos metodológicos: a revisão teórica-conceitual, análise de dados estatísticos coletados nos sites do Instituto Brasileiro de Geografia e Estatística (IBGE), da Companhia Nacional de Abastecimento (Conab) e do trabalho de campo desenvolvido junto ao Grupo de Pesquisa em Gestão do Território e Geografia Agrária da Amazônia - GTGA, do Laboratório de Gestão do Território - Laget/UNIR.

\section{A dinÂmica eConômica na Amazônia Brasileira - Breve histórico}

Historicamente, o Brasil sempre se destacou na escala global como um país produtor e exportador de produtos primários. Desde a colonização predatória do século XVI, o território brasileiro serviu de celeiro para abastecer as metrópoles europeias cujos produtos eram destinados ao consumo das classes privilegiadas deste continente.

Cinco séculos após a colonização portuguesa, o Brasil continua como mero produtor e exportador de produtos primários. Durante esse período (da colonização ao século XXI), o mundo registrou inúmeros acontecimentos que marcaram a história moderna e contemporânea: o aprimoramento da ciência, as inovações técnico-científica-informacional, a supremacia do capitalismo, ascensão e queda do socialismo real, a emergência do neoliberalismo e, não menos importante, a ascensão dos movimentos sociais que nasce da necessidade de conquista de direitos, marcaram a historiografia mundial em suas respectivas temporalidades. Ao mesmo tempo, o mundo tornou-se um espaço multifacetado, as 


\section{Territorialização, expansão e contradições do agronegócio \\ no espaço agrário de Rondônia}

nações desenvolvidas passaram a exercer forte influência política e econômica sobre as nações subdesenvolvidas. Paralelamente a essa incursão, despontaram as desigualdades socioeconômicas e a elevação da pobreza entre países e sociedades menos favorecidas, inseridas ao processo da globalização mundial.

Por outro lado, o mundo do trabalho não-qualificado padece diante da sistematização da automação, da robótica e da microeletrônica que se tornaram indissociáveis nessa complexa e cíclica cadeia produtiva global. Por sua vez, as transnacionais emergiram como principais agentes condutores desse modelo econômico, tornando-se empresas cada vez mais lucrativas à medida que se apropriam dos recursos naturais, humanos e dos benefícios fiscais das nações subdesenvolvidas, que por vez, se transformaram em verdadeiros redutos de suas espoliações (Santos, 2008).

Analisando o atual modelo econômico mundial e a organização espacial, Moreira (2015) destaca que o século XX consagra a era da mundialização da indústria e dos territórios planejados e ordenados pela intervenção do Estado. O debate é plural, pois inclui uma diversidade de fatores e elementos que transformam o espaço de forma linear e sistemática, bem como os efeitos por eles constituídos como: a origem de novos arranjos econômico-espaciais, as transformações socioespaciais e os impactos socioambientais.

O espaço, por sua vez, passa a incorporar novas estruturas econômicas, na qual é organizado e passa a ser regido pela imposição de novas normas territoriais que são criadas pelas relações capitalistas de produção, tornando espaços complexos, dinâmicos e, consequentemente, contraditórios. Nessa dinâmica de transformação espacial, R. L. Corrêa explica o sentido dos arranjos espaciais como

Um conjunto de localizações disposto sobre a superfície terrestre, seja uma cidade, uma região ou todo um país. Como conjunto descreve a organização espacial, constituindo uma complexa forma espacial, resultado de longos e também complexos processos [...]. Os arranjos espaciais são mutáveis, exibindo uma dada permanência obedecendo a uma escala temporal, ou seja, as interações espaciais constituem os elos que conectam as diversas localizações. Estas têm a sua existência e reprodução garantidas pelas interações, que assim garantem as 


\section{Geografias de Rondônia Território, Fronteira e Educação}

relações econômicas, políticas e sociais da sociedade (Correa, 2019, p. 292).

Esses espaços ganham novas configurações, inseridos no circuito da economia global, resultando na articulação entre as forças inerentes aos interesses materiais da sociedade e aquelas do poder simbólico dos agentes econômicos, tanto produtores quanto consumidores (Castro; Gomes; Corrêa, 2012).

Até meados do século XX, o espaço agrário se estruturava como verdadeiras "ilhas econômicas" consolidadas na produção de cana-de-açúcar, algodão, borracha e café, cuja produção era organizada com vistas à exportação. Entretanto, transformações ocorreram na dinâmica agrícola nacional a partir da década de 1960.

Segundo Andrades e Ganimi (2007) a evolução da agricultura brasileira, assim como de outros países, incluiu não apenas sua diversificação, mas possibilitou o início da modernização e especialização produtiva ampliando a relação com mercado externo, sobretudo, com a política da "Revolução Verde" operacionalizada pelo capital privado dos EUA, que passou a controlar grande parte da produção agrícola mundial através de seus agentes econômicos.

No Brasil do século XXI, diversos setores da economia continuaram seu processo de modernização na tentativa de acompanhar a tendência e a competitividade da economia mundial. Sem dúvida, a agropecuária foi um dos setores que mais se modernizou nos últimos vinte anos, transformando-se na vanguarda das exportações brasileiras. A expansão do agronegócio brasileiro transformou o país num líder mundial na produção de grãos e carne, integrando a região ao circuito da produção em escala global (Vieira Filho, 2019).

De economia tipicamente extrativista, a Amazônia se transformou numa região geoestratégica, dada importância que passou a representar no cenário nacional com a implantação dos projetos de colonização desencadeados pelo governo federal a partir da década de 1960. A abertura da Transamazônica e da BR-364 instigou a imigração e integrou a região ao Centro-Oeste e Nordeste do país, iniciando a fase desenvolvimentista da Amazônia brasileira (Becker, 2007).

A abertura das rodovias desencadeou inúmeros problemas à região: o aumento da migração, a intensa exploração dos recursos naturais, o aumento exponencial da grilagem de terras, os conflitos sociais no campo e invasão aos territórios indígenas, ribeirinhos, quilombolas, 


\section{Territorialização, expansão e contradições do agronegócio \\ no espaço agrário de Rondônia}

posseiros e camponeses, manifestando-se disputas de territórios na linha da fronteira.

A face dessa ocupação proposta pelo governo demostra sua contradição. Enquanto predominava a economia extrativista familiar na região, as características físicas e sociais permaneceram quase inalteradas. A incorporação dos projetos agropecuários e minerais sobre o território amazônico promoveu mudanças significativas no espaço natural e no modo de vida dos povos da região.

Esses novos espaços se consolidaram, ao longo de décadas, pela presença do capital agrário nacional e estrangeiro, que impõem seus modelos econômicos, centrados na lógica dos mercados que ordena a produção e o consumo mundial. Nesse contexto, Martins (2014) destaca o mecanismo da acumulação primitiva do capital, que atinge de forma violenta e especulativa as comunidades tradicionais da Amazônia, assegurando com isso, a reprodução ampliada do capital, produzida com o deslocamento das frentes pioneiras e as frentes de expansão.

A história do recente deslocamento da fronteira amazônica, sobretudo com o avanço do agronegócio, especialmente no estado de Rondônia, é marcada pela destruição da natureza, pela desterritorialização e pelos conflitos no campo. Por outro lado, ascende as lutas sociais e a resistência de grupos sociais vulneráveis, frente ao capital agrário, despertando o senso de sobrevivência e existência dos mesmos.

\section{RONDÔNIA: UMA FRONTEIRA EM MOVIMENTO}

Para entender o percurso da dinâmica socioespacial de Rondônia é preciso conhecer seu processo da colonização. A colonização da Amazônia na década de 1960, não foi algo pensado aleatoriamente, ao contrário, o plano governamental era transformar a região num espaço de produção, especulação e acumulação de capital, que ocorreu a partir da integração física e econômica às demais regiões brasileiras. Foram implementados modelos distintos de exploração e apropriação do território, a exemplo da colonização pública e privada ${ }^{1}$ que se estabeleceram de forma ordenada no espaço amazônico, em especial no estado de Rondônia.

\footnotetext{
${ }^{1}$ A primeira foi organizada e estruturada pelo governo federal da qual, coube ao Instituto Nacional de Colonização e Reforma Agrária (Incra), ordenar o território em pequenas parcelas a fim de assentar famílias que migraram para a região constituindo um campesi-
} 


\section{Geografias de Rondônia Território, Fronteira e Educação}

Nesse contexto, a Amazônia emerge como uma região de concretização de políticas públicas territoriais sujeita a transformações espaciais e territoriais múltiplas. O período correspondente de 1960-2021 demostra uma região metamorfoseada pela ação do capital hegemônico. A abertura de estradas como a BR-364 e a BR-163, intensificou o fluxo migratório em direção aos estados de Rondônia, Pará e Mato Grosso. O recorte rodoviário desenhado sobre a Amazônia Legal acelerou a corrida pela posse da terra nesses estados, consolidando uma espacialidade singular para região: territórios do campesinato e territórios da burguesia agrária (agronegócio) passaram a fazer parte da geografia agrária da Amazônia (Costa Silva, 2018).

Durante seis décadas a Amazônia se transformou numa região heterogênea, dada à forma de ocupação e uso do solo, a exploração dos recursos naturais, os empreendimentos agrominerais que se territorializaram na região, alteraram as características socioespaciais dos lugares. A expansão e modernização da agropecuária, bem como de outros segmentos econômicos como os projetos hidrelétricos, incorporados à região construíram novas territorialidades na fronteira amazônica, alterou a geografia rural/urbana da região e promoveu transformações irreversíveis de dimensões imensuráveis no âmbito social, ambiental, cultural e econômico regional.

As mudanças verificadas no uso do solo rondoniense, desde a colonização até a modernização da agropecuária, contribuíram para a inserção da região no contexto econômico mundial. Ao analisar a colonização de Rondônia, Amaral (2004, p. 32) entende esse processo como "a incorporação do espaço ocupado por determinada sociedade, o que significa que esse espaço será organizado dentro da lógica institucional de expansão das relações capitalistas".

Contudo, a colonização não ocorreu isoladamente. À medida que novas áreas são incorporadas ao modelo de produção em curso, novas territorialidades vão emergindo no contexto agrário regional em detrimento do modelo econômico tradicional, que se converte no bojo do sistema de produção moderno e globalizado, consolidada por políti-

nato dedicado a agricultura tradicional. O segundo modelo se caracteriza pela implantação do projeto fundiário criado pelo governo federal visando à legalização da propriedade da terra aos que invadiram e/ou se apropriaram das terras devolutas, bem como pelos que adquiriram a preço irrisório formando grandes latifúndios (Théry, 2012). 


\section{Territorialização, expansão e contradições do agronegócio \\ no espaço agrário de Rondônia}

cas governamentais voltadas, entre outros, pela territorialização do capital no campo (agronegócio).

Em Rondônia, a política governamental evidenciada pelo Projeto de Integração e Colonização (PIC), corroborou para elevar a taxa de imigração, haja vista que esses foram instalados paralelamente a BR-364, motivo que favoreceu o aumento exponencial de famílias em busca de terras na região central do estado.

Doravante, inúmeros problemas foram constatados na realização desses projetos após o assentamento das famílias. Muitos dos lotes ocupados se situavam sobre um solo de baixa fertilidade. A falta de infraestrutura para escoamento da produção, a ineficiência de acompanhamento técnico, o difícil acesso à saúde e educação, somadas a outras dificuldades levaram muitos migrantes abandonarem ou venderem seus lotes (Théry, 2012; Amaral, 2004; Cunha; Moser, 2010).

Paralelo ao projeto de assentamento público, ocorreu em Rondônia a colonização de caráter privada, do qual se destaca o Projeto Fundiário Corumbiara criado em 22/09/1975 abrangendo municípios como Vilhena, Pimenta Bueno, entre outros. Nesses municípios, a política de colonização resultou numa dicotomia da estrutura agrária da região. De um lado a organização social e territorial constituído pelo campesinato, do outro, a formação de latifúndios que se especializaram na produção agrícola e/ou na pecuária extensiva. Esse modelo de colonização foi organizado por empresas privadas, cabendo ao Estado investir em infraestrutura, pesquisa e planejamento para facilitar a atuação do capital agrário na região (Santos, 2007). Nesse contexto,

A expansão da malha fundiária, contendo milhares de propriedades rurais, compôs a espacialidade da colonização, estabelecendo territórios do campesinato e territórios da burguesia agrária (médios e grandes proprietários e empresas agropecuárias), cristalizando assim, lógicas diferenciadas e contraditórias no espaço agrário amazônico (Costa Silva, 2018, p. 26).

O processo de modernização agrícola que se perpetuou no espaço agrário de Rondônia a partir da década de 1980, cristalizou-se por meio da expansão da pecuária e, no final da década de 1990, com a produção de grãos, no sul de Rondônia, centralizada, no município de Vilhena. Contudo, a territorialização do agronegócio se consolida e ganha novos contornos à medida que as exportações de commodities cresce no cená- 


\section{Geografias de Rondônia Território, Fronteira e Educação}

rio regional e passa a ser controladas por grandes corporações multinacionais (Ammagi e Cargill), que comanda a produção e comercialização dos grãos produzidos no espaço rondoniense.

A figura 1, representa o processo de territorialização e expansão da soja em Rondônia.

Figura 1 - Expansão/espacialização da soja em Rondônia entre 1990-2019.

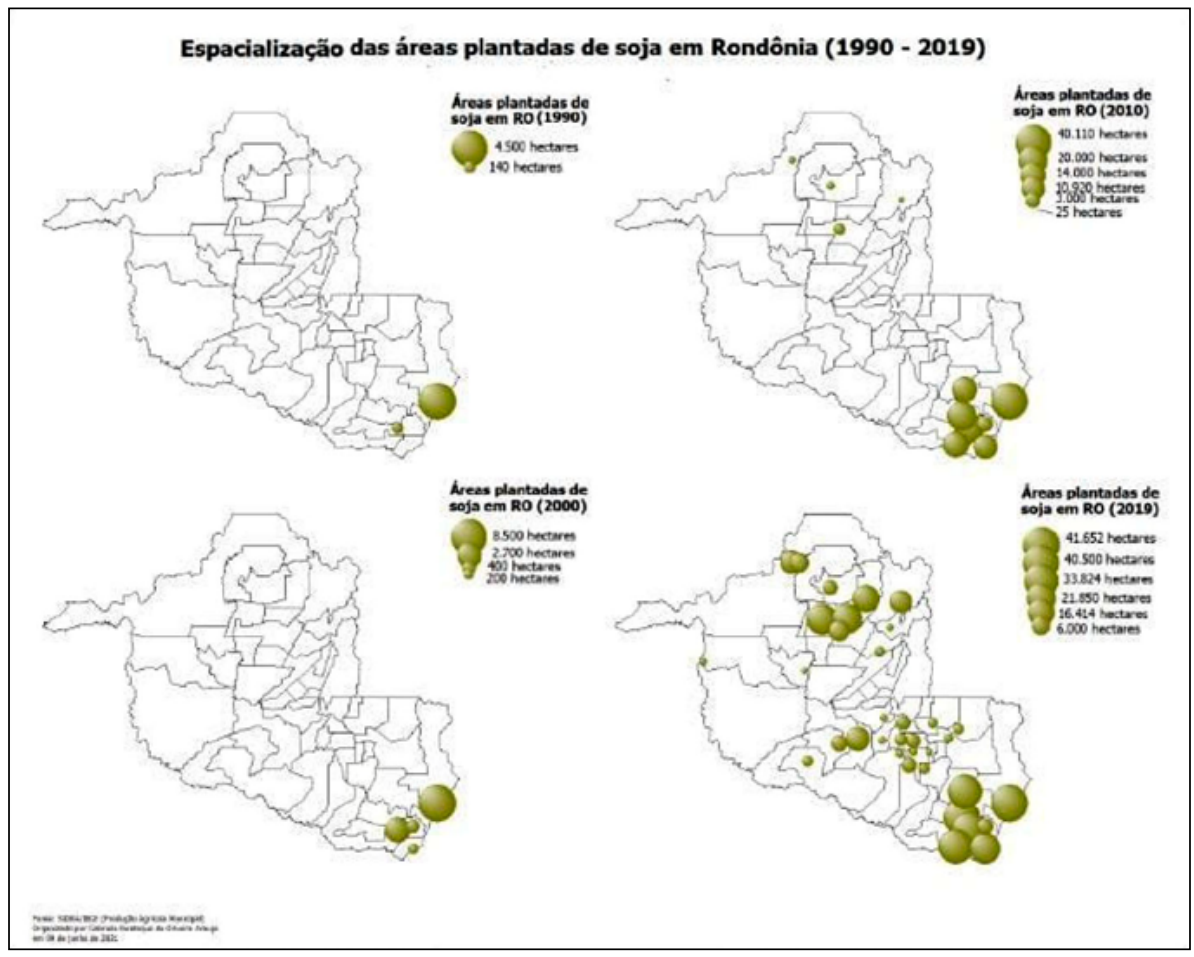

Fonte: IBGE/Sidra (Produção Agrícola Municipal). Organizado por Groa, 2021.

A chegada de empreendimentos comerciais ligados ao setor agropecuário associada a ampliação e o melhoramento da logística e da infraestrutura necessária ao funcionamento dessa cadeia produtiva foram essenciais para consolidação do agronegócio nos municípios do cone sul do estado e, consequentemente, sua expansão para outras áreas (Kahil; Pereira, 2010). 


\section{Territorialização, expansão e contradições do agronegócio \\ no espaço agrário de Rondônia}

Na esfera econômica, a territorialização do agronegócio no sul de Rondônia contribuiu para intensificar a concentração de terras na região. $\mathrm{O}$ estrato fundiário delineado nessa região foi responsável pelo crescente índice de conflitos agrários no campo.

Isso se deve porque "a modernização conservadora da agricultura conduzida pelos agentes hegemônicos do agronegócio ampliou os conflitos agrários em Rondônia" (Costa Silva; Conceição, 2017, p. 58). Não é de se estranhar que a expansão da agricultura capitalista globalizada exerceu e exerce forte pressão sobre o território do campesinato deflagrando atos de violência e, consequentemente, assassinatos de lideranças camponesas.

O processo de territorialização do agronegócio no sul de Rondônia, promoveu transformações significativas no espaço agrário regional. De acordo com Costa Silva e Conceição (2017), as disputas territoriais e a concentração fundiária são evidentes no território do agronegócio, supervalorizando o preço das terras destinadas à produção de commodities. Portanto, a pressão sobre o estoque de terras, disponíveis nos munícipios do sul do estado, contribuiu para elevação do preço da terra, a grilagem e a desterritorialização de camponeses, resultando em violentos conflitos.

\section{A TERRITORIALIZAÇÃO DO AGRONEGÓCIO EM RONDÔNIA E SUAS CONTRADIÇÕES}

A territorialidade e territorialização "representa a ligação de como as pessoas utilizam a terra e, como elas próprias se organizam no espaço e como dão significado ao lugar" (Haesbaert, 2014, p. 59).

Para Paulino (2012), no campo ocorre uma relação antagônica representada na lógica estabelecida entre campesinato e agronegócio, pois as formas de usos da terra e do território se diferem entre as classes sociais. A primeira, constitui-se em terra de trabalho e de sobrevivência familiar, e a segunda, configura-se em terra de negócio, de exploração de trabalho, de reserva de valor (Martins, 2014).

A territorialização do agronegócio e a diversidade do uso do solo na Amazônia Legal vêm alterando significativamente a paisagem e a configuração do espaço regional. Em Rondônia, essas mutações se multiplicaram e se concentraram no sul do estado, principalmente no município de Vilhena. As características naturais (clima e solo) da região favoreceram a introdução da monocultura de grãos, que se estendeu expres- 


\section{Geografias de Rondônia Território, Fronteira e Educação}

sivamente para cidades circunvizinhas. A dinâmica agrária dessa região passou a exercer uma caraterística peculiar dentro do espaço agrário rondoniense. A entrada das tradings Cargill Agrícola S/A e Amaggi Exportação e Importação Ltda., acelerou o processo de territorialização e controle do mercado de produção e exportação do complexo soja/ milho na região.

A produção agroexportadora de grãos é baseada na relação D-M-D (Dinheiro-Mercadoria-Dinheiro), dos quais grupos empresariais controlam a cadeia produtiva das commodities agrícolas. Para tanto, cria-se uma rede de relação administrativa, econômica e política que garanta o funcionamento dos impérios alimentares. Bunge, Cargill, ADM, LDC, Ammagi, Noble, JBS, são exemplos de tradings e agroindústrias que tradicionalmente comandam circuitos espaciais da produção na região (Castilho et al., 2016; Costa Silva, 2014b).

Por outro lado, a Embrapa Rondônia vem fomentando a pesquisa de grãos no campo experimental de Vilhena, contribuindo com a expansão da cultura da soja no cerrado rondoniense. Essas pesquisas vêm ganhando proporções quali-quantitativa no setor agrícola regional. Os resultados desses estudos apontam a transferência de tecnologia para produtores, o que tem sido decisivo para consolidação e expansão da área plantada no estado. Dessa forma, a monocultura da soja/milho vem ganhando espaço em municípios como: Ariquemes, Itapuã do Oeste, Machadinho D'Oeste e Porto Velho.

A viabilidade econômica e a elevada produtividade do cultivo da soja têm incentivado a especulação fundiária, promovendo a incorporação de novas áreas no processo de produção de commodities, resultando na expulsão de camponeses(as) e a precarização do trabalho no campo e na cidade (Costa Silva, 2014b).

No centro dessa dinâmica econômica, compreender a importância estratégica do sistema de transporte, dentro da cadeia produtiva do agronegócio regional, é fundamental para a fluidez do mesmo. Em Rondônia, o sistema intermodal BR-364-Hidrovia Madeira-Amazonas, são objetos fixos cuja finalidade é atender a demanda de exportação de grãos e carnes. Por meio dele, grãos produzidos em Mato Grosso e em Rondônia são escoados para Itacoatiara, no Amazonas e, posteriormente, para o exterior (Nunes, 2004).

$\mathrm{O}$ volume de exportação de grãos via rio Madeira-ItacoatiaraMercado Externo, cresce consideravelmente ano a ano, levando o estado e as empresas privadas a investirem em infraestrutura e tecnolo- 


\section{Territorialização, expansão e contradições do agronegócio \\ no espaço agrário de Rondônia}

gia, visando modernizar o setor portuário localizado na cidade de Porto Velho, que é o centro de gestão dos fluxos de mercadorias de Rondônia. O sistema de circulação de mercadorias, além de contribuir na organização do território, objetiva reduzir o tempo e custo da produção em escala global.

\section{A DINÂMICA DA PRODUÇÃo DE COMMODITIES EM RONDÔNIA}

As políticas e os programas de governo ao longo das últimas seis décadas tinham como objetivo central modernizar a economia nacional, dentre as quais a agropecuária. Almejava-se promover uma agricultura mais produtiva e competitiva e inserir o setor agrícola na lógica da produção industrial. $\mathrm{O}$ advento e a expansão do agronegócio passou a ser controlado por grandes empresas nacionais e transnacionais.

O processo de globalização do século XXI impõe aos países produtores de commodities modelos de Regimes Alimentares Internacionais ${ }^{2}$, com base na organização empresarial de um complexo agroalimentar transnacional centrado, principalmente, nos países produtores e exportadores de produtos agropecuários.

No Brasil, acompanhamos a difusão da produção de grãos de forma jamais vista nos últimos vinte anos. Se olharmos para a geografia da soja e do milho no espaço agrário brasileiro, é possível compreender sua dimensão. Nas últimas duas décadas, espaços considerados ociosos passaram a receber investimentos técnico-científicos, transformando-se em pontos estratégicos de produção e exportação de grãos.

A região do MATOPIBA é um exemplo clássico dessas metamorfoses espaciais. Considerada a grande fronteira agrícola nacional da atualidade, compreende o bioma Cerrado dos estados do Maranhão, Tocantins, Piauí e Bahia e respondendo por grande parte da produção brasileira de grãos e fibras, que se estabeleceu com a intensificação das relações de produção tipicamente capitalistas. No Relatório da Conab (2020/21), a safra de soja 2020/21 dos estados do MATOPIBA, foi de 6,838 milhões de toneladas na Bahia, 3,526 milhões de toneladas no

${ }^{2}$ Philip McMichael, define Regimes Alimentares Internacionais como uma ordem mundial capitalista regida pelas regras que estruturam a produção e o consumo de alimentos pelo mundo. 


\section{Geografias de Rondônia Território, Fronteira e Educação}

Tocantins, 3,285 milhões de toneladas no Maranhão e 2,719 milhões de toneladas no Piauí.

No artigo "Ensaios sobre os espaços agrícolas de exclusão" Denise Elias explica a complexidade da difusão das técnicas e suas consequências no âmbito da agricultura em regiões produtivas agrícolas como o MATOPIBA.

A difusão da agricultura científica e do agronegócio, com a territorialização do capital, inclusive de importantes multinacionais, passa a dominar parte significativa da produção, da comercialização e do financiamento, mas não se associa à distribuição de terra, nem de renda para os pequenos produtores (Elias, 2006, p. 6)

Os grandes conglomerados passaram a dominar o mercado mundial de sementes e agrotóxicos. O número de empresas que exercem o controle desse mercado vem diminuindo, não porque decretaram falência e, sim, pelas fusões estabelecidas entre elas, a exemplo da Monsanto que foi incorporada a Bayer.

De acordo com os dados do Atlas do Agronegócio (2018), em 2017, outras duas gigantes, DuPont e Dow Chemical, ambas dos EUA, se fundiram na DowDuPont, e a ChemChina comprou a empresa suíça Syngenta por US $\$ 43$ bilhões. Assim, os três conglomerados recém-formados devem dominar mais de $60 \%$ do mercado de sementes comerciais e de agrotóxicos (Santos; Glass, 2018).

As commodities soja, milho, cana-de-açúcar e algodão concentram $85 \%$ do total de agrotóxicos utilizados nas lavouras do país. Dados do Atlas do Agronegócio mostram que entre 2000 e 2012 no Brasil - período de maior expansão das áreas de soja e milho transgênicos - esse número cresceu $160 \%$, sendo que na soja aumentou em três vezes. Só a soja, predominante entre as culturas geneticamente modificadas, utiliza 71\% desse volume (Santos; Glass, 2018).

Contudo, dados da Conab apontam que a safra de soja 2020/21 no Brasil, atingiu 135,914 milhões de toneladas numa área plantada de 38,530 milhões de hectares. Ano a ano, o país amplia sua área de produção. Com o aprimoramento das técnicas e o uso das tecnologias no campo, a produtividade nesse período chegou a $3.527 \mathrm{~kg} / \mathrm{ha}$. Cabe destacar a importância da produção do Mato Grosso. Nessa safra, o 


\section{Territorialização, expansão e contradições do agronegócio \\ no espaço agrário de Rondônia}

estado contabilizou 35.886 milhões de toneladas de soja numa área estimada em 10,297 milhões de hectares, atingindo uma produtividade 3.485 $\mathrm{kg} / \mathrm{ha}$.

No que tange às exportações do complexo soja, o resultado de 2020 foi positivo para a balança comercial brasileira. De janeiro a dezembro o país vendeu 82,978 milhões de toneladas ao exterior, alta de $12 \%$ ante 2019 , fechada em 74,063 milhões de toneladas.

Seguindo a tendência da produção nacional, a região Norte, apesar de apresentar a menor produção de grãos do país, vem aumentando a área de plantio. De acordo com o relatório da produção de grãos da Conab (2021), a área plantada na região foi de 2,332 milhões de hectares, na produção regional atingiu 7,337 milhões de toneladas. Os estados que apresentaram melhores resultados foram: Tocantins, Pará e Rondônia.

No cenário econômico atual, a agricultura comercial de larga escala se tornou um setor atrativo de investimentos financeiros. A expansão do setor se alastra por todas as regiões do país, sua voracidade ganha espaço à medida que novos territórios são anexados a esse modelo de produção, seja por meio de aquisição ou arrendamento de terras. $\mathrm{O}$ foco polarizador do estoque de terras, disponível em quantidade no Brasil, está na Amazônia, por isso é notória a nova corrida migratória por terras na região. A consequência desse processo implica diretamente no meio natural, na expropriação e/ou expulsões dos povos originários de seus territórios e no aumento exacerbado da grilagem de terras na região.

O aumento da demanda das commodities no mercando internacional tem contribuído consubstancialmente para o acréscimo da produção de grãos e carne, e pela ocupação de novos espaços produtivos na Amazônia brasileira. O agronegócio recebe incentivo de políticas governamentais para consolidar a territorialização do capital e o avanço da monocultura na região.

Embora sejam moderadas as avaliações governamentais para a Amazônia, o crescimento da produção e área agrícola com soja e milho na região indica intenso processo de territorialização do capital, ocupando áreas que outrora se destinavam à pecuária e à pequena produção agrícola. Essas perspectivas nos remetem a analisar os efeitos territoriais das macropolíticas agrícolas desenvolvidas pelo governo federal na região amazônica (Costa Silva; Conceição, 2017, p. 65). 


\section{Geografias de Rondônia Território, Fronteira e Educação}

De acordo com os dados do Censo Agropecuário do IBGE (2017), Rondônia apresentou aumento no número de propriedades que passaram a produzir soja e milho. Segundo a pesquisa, 402 estabelecimentos rurais introduziram a soja em suas lavoras, enquanto que 4,5 mil propriedades produziram milho em grãos na safra de 2018/2019. O estudo aponta que esse incremento se deu, sobretudo, pela ocupação de áreas de pastagens degradadas, com o plantio avançando para a região central e norte do estado.

O Boletim Agropecuário da Embrapa de Rondônia de 2021 destaca que a área plantada com soja na safra 2020/21 foi estimada em 396,5 hectares(ha) apresentando um acréscimo de 13,8\% em relação à safra de 2019/20 cuja área era de 348,4 mil ha. Nos últimos cinco anos, o aumento da área plantada foi de $44,1 \%$, enquanto a produção e produtividade cresceram $49,4 \%$ e $3,7 \%$, respectivamente (Calixto; Silva; Araújo, 2019). O aumento da área plantada com soja em Rondônia está relacionado principalmente ao aumento do preço no mercado internacional. 
Territorialização, expansão e contradições do agronegócio no espaço agrário de Rondônia

Figura 2 - Evolução da área plantada, produção e produtividade da soja em Rondônia em relação ao país (safra 2016-2019).

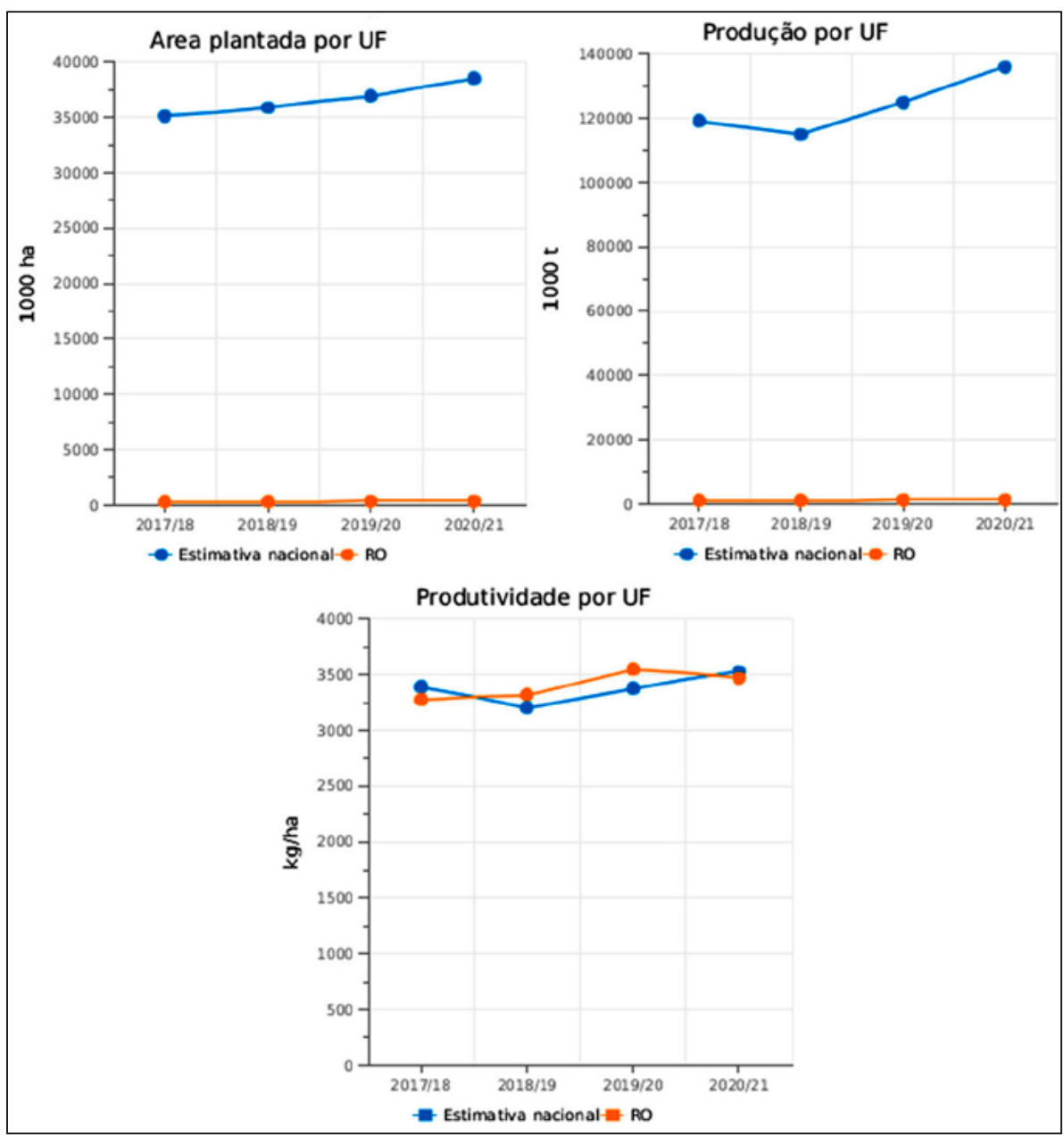

Fonte: Conab, 2021. Organizado pelo Autor.

Com base nos dados da Figura 2, observa-se um crescimento linear tanto da área plantada quanto da produção de soja no estado. $\mathrm{Na}$ safra 2017/2018 o total produzido foi de 1,095 milhão de toneladas, enquanto que em 2018/2019 somou 1,109 milhão de toneladas, resultado da incorporação de novos territórios que introduziram o cultivo do grão. 


\section{Geografias de Rondônia Território, Fronteira e Educação}

Na safra 2018/2019, Rondônia teve uma produtividade de $3.320 \mathrm{~kg}$ por ha, superando a média nacional que foi de $3.206 \mathrm{~kg}$ por ha. Já na safra de 2020/2021 a produtividade média de Rondônia $(3.472 \mathrm{~kg} / \mathrm{ha}$ ) apresentou uma leve queda em relação à média nacional $(3.527 \mathrm{~kg} / \mathrm{ha})$.

A geografia do agronegócio em Rondônia vem se desenhando ao longo de duas décadas, principalmente com a expansão da cultura da soja e do milho. A cidade de Vilhena, tornou-se a centro regional do agronegócio. Nela se concentra grande parte dos serviços técnico-operacional como lojas especializadas em produtos agropecuários, empresas de transportes, técnicos agropecuários, que atende a demanda local e as cidades circunvizinhas, que depende da logística necessária para dar funcionalidade ao complexo agroindustrial que se constituiu no cone sul do estado, como explica Costa Silva sobre a consolidação do agronegócio na cidade de Vilhena.

Vilhena assume o comando e a gestão da produção de soja. Os equipamentos urbanos são acrescidos de agências bancárias, cooperativas de créditos, lojas especializadas em prestação de serviços tecnológicos que ajudam a construir uma solidariedade organizacional do capital. Como centro de logística Vilhena concentra as principais empresas de transportes de grãos, as empresas de maquinários e a assistência técnica que completa a sua função de centro local da economia urbana do agronegócio (Costa Silva, 2014b, p. 308).

No contexto da economia agrária de Vilhena e região, a modernização da agropecuária transformou a geografia regional (campo/cidade), à medida que impulsionou a produção de novas mercadorias, seja na verticalização da produção, em que emergem a agroindústria regional, como na horizontalização das cadeias produtivas, dada a expansão do espaço agrícola articulado aos circuitos espaciais da produção, aumentando cada vez mais o intercâmbio entre campo e cidade (Costa Silva, 2014a).

As mudanças observadas no sistema de produção da agropecuária beneficiaram, principalmente, os médios e grandes proprietários rurais formando os Complexos Agroindustriais regionais. Essas empresas passaram a expandir suas atividades em espaços cada vez mais dinâmicos constituindo grandes latifúndios monocultores, implicando na característica da geografia social e espacial do lugar, como explica Domingues e Bermann (2012, p. 9). 


\section{Territorialização, expansão e contradições do agronegócio no espaço agrário de Rondônia}

As grandes empresas ocupam espaços no campo antes ocupado por culturas diversificadas e familiares, reduzindo o emprego e a capacidade de produção de alimentos tradicionais, e comprometendo a segurança alimentar da população. Esse processo tem levado ao aumento do deslocamento de pequenos colonos, em razão de conflitos sociais ou da compra de lotes, com a consequente expulsão dos colonos (Domingues e Bermann (2012, p. 9).

$\mathrm{Na}$ fronteira corporativa de Rondônia, nos empreendimentos agropecuários prevalece a lógica capitalista de produção, a terra de negócio. Em Vilhena, parte das pequenas propriedades rurais foi incorporada a monocultura de grãos como forma de arrendamento, resultando num deslocamento de uma massa de camponeses para as cidades.

A expansão do agronegócio em Vilhena se consolida de forma contraditória. Ao mesmo tempo em que transforma territórios, expropria e desterritorializa camponeses, subjugando-os a condições extremas, incluindo a relação de trabalho capitalista e o êxodo rural. Esse processo ocorre em função do crescimento do mercado de terras e, sobretudo do interesse do capital agrário-industrial-financeiro na região (Ricarte, 2017).

Outros municípios do cone sul de Rondônia vêm se destacando na produção de commodities: Cabixi, Cerejeiras, Chupinguaia, Colorado do Oeste, Corumbiara e Pimenteiras do Oeste. O quadro 1 representa os valores quantitativos da área plantada, produção total e a produtividade por hectare dos cinco municípios de maior produção do Cone Sul de Rondônia em 2020, de acordo com os dados do IBGE.

Quadro 1 - Dados referentes à produção de soja dos municípios do Cone Sul de Rondônia, 2020.

\begin{tabular}{|l|c|c|c|}
\hline \multicolumn{1}{|c|}{ Município } & $\begin{array}{c}\text { Área plantada } \\
\text { (ha) }\end{array}$ & $\begin{array}{c}\text { Produção } \\
(\mathbf{t})\end{array}$ & $\begin{array}{c}\text { Produtividade por }(\mathrm{kg} / \\
\text { ha) }\end{array}$ \\
\hline Vilhena & 54.000 & 197.640 & 3.660 \\
\hline Corumbiara & 40.500 & 142.800 & 3.525 \\
\hline Cerejeiras & 36.150 & 140.760 & 3.894 \\
\hline $\begin{array}{l}\text { Pimenteiras do } \\
\text { Oeste }\end{array}$ & 37.352 & 145.145 & 3.886 \\
\hline Chupinguaia & 35.500 & 122.200 & 3.442 \\
\hline
\end{tabular}

Fonte: IBGE, 2021. Organizado pelo Autor. 


\section{Geografias de Rondônia Território, Fronteira e Educação}

Dados do Quadro 1 mostram que Vilhena lidera o ranking entre os municípios destacados, tanto em área plantada quanto na produção de soja. Na produtividade o destaque fica com Cerejeiras totalizando $3.894 \mathrm{~kg} / \mathrm{ha}$, seguido por Pimenteiras do Oeste $(3.886 \mathrm{~kg} / \mathrm{ha})$ e Vilhena $(3.660 \mathrm{~kg} / \mathrm{ha})$.

Geograficamente, a produção de soja e milho em Rondônia vem ocupando novos espaços fora do eixo-sul é o caso de Rolim de Moura e Machadinho D'Oeste, enquanto que no sentido centro-norte do estado, seguindo a linha da BR-364, a cultura da soja chegou aos municípios de Ariquemes, Itapuã do Oeste, Candeias do Jamari e Porto Velho.

No Censo Agropecuário do IBGE (2017), a soja lidera a produção agrícola em Rondônia com 48,4\%; seguida do milho com 29,8\%; o café com 8,3\%; e o arroz 5,6\% (Diário da Amazônia, 2019).

$\mathrm{Na}$ perspectiva geoeconômica de Rondônia, o cenário da produção e exportação dos produtos primários, especialmente grãos e carnes ganham novos mercados em escala global. A Coordenadoria de Desenvolvimento Agropecuário da Secretaria de Agricultura de Rondônia (Seagri) revela que:

A carne representa 53\% no cômputo geral das exportações no estado de Rondônia. A soja, até o momento $26 \%$. Contudo, a carne entra nesta faixa com apenas $13 \%$ de todo o bolo do que é exportado pelo Estado. O volume exportado pelo estado de Rondônia em 2019 totalizou 212,2 milhões de toneladas com destaque para soja com 127,2 mil toneladas, representando US\$ 43,4 milhões, que ao serem convertidos em reais representam algo em torno de $\mathrm{R} \$ 166,3$ milhões. O estado exportou neste período 27,1 mil toneladas de carne, entesourando em US\$ 80,7 milhões, o que representa $\mathrm{R} \$ 340,8$ milhões de reais. O impressionante é que a soja participa com $60 \%$ do volume de tudo que é exportado. Soja e carne totalizam $79 \%$ de todo o valor que é negociado no mercado interno e $73 \%$ do volume exportado para o mundo, principalmente para Ásia, China e outros países (Alves, 2019).

O mercado das commodities em escala global vem incentivando e fomentando o avanço da monocultura no estado. Essa dinâmica agrária associada à pecuária extensiva corrobora significativamente para a incorporação de novos territórios, implicando numa forte pressão sobre as 


\section{Territorialização, expansão e contradições do agronegócio \\ no espaço agrário de Rondônia}

áreas preservadas, resultando no aumento de conflitos sociais, na supressão das florestas e na prática criminosa da grilagem de terras. Trata-se, portanto, de uma política dilapidadora do patrimônio natural. Ameaças e assassinatos de lideranças camponeses, posseiros, indígenas, cresce na mesma velocidade que se expande o agronegócio na Amazônia brasileira.

\section{CONSIDERAÇÕES FINAIS}

A política de colonização planejada para Rondônia na década de 1970, que resultou na distribuição de terras públicas, foi relevante para a formação da estrutura fundiária do estado. Enquanto na região central do estado predominou a pequena propriedade camponesa/familiar, na porção sul, o estrato fundiário se consolidou, sobretudo na formação de latifúndios, que, a princípio, tinha na pecuária extensiva sua principal fonte de renda.

A espacialização dessas culturas acarretou inúmeras consequências no contexto socioeconômico, ambiental e regional. A busca por novos territórios contribuiu para a fragilização da organização do espaço agrário de Rondônia, pois coloca em evidência a territorialização dos povos tradicionais e das áreas de preservação que estão na linha da fronteira agropecuária.

A pressão sobre os territórios vulneráveis (TIs e UCs) retrata a corrida pela terra. Essa prática tem sido comum em toda Amazônia em virtude do estoque de terra disponível. Esta tendência vem corroborar para a prática da grilagem.

No final da década de 1990, quando teve início o plantio da soja no sul de Rondônia, especialmente na cidade de Vilhena, o baixo preço da terra atraiu imigrantes do sul do Brasil e do Mato Grosso. Os incentivos financeiros, a pesquisa no setor da biotecnologia e a chegada das tradings do agronegócio (Cargill e Amaggi) contribuíram para transformar a região num centro estratégico e de grandes empreendimentos agropecuários do estado. Vinte anos após essa iniciativa, observa-se na dinâmica agrária de Rondônia o espraiamento da monocultura e da pecuária extensiva pelo território.

Apesar das estatísticas do setor agropecuário do estado apresentarem números positivos, é preciso compreender que a mudança no comportamento econômico, que se estabeleceu no espaço agrário de Rondônia, é fruto da política de fomento que se desenha em escala global. 


\section{Geografias de Rondônia Território, Fronteira e Educação}

A crescente demanda por alimentos no mundo, incentiva o aumento escalonar da produção e exportação de commodities. Por outro lado, intensificou-se a degradação dos recursos naturais, o aumento da desigualdade social no campo e, a violação dos direitos humanos.

Atualmente, a Amazônia se coloca no epicentro desse paradigma econômico, que se consolidou no país. Os estados de Rondônia, Mato Grosso, Pará e, mais recentemente, o Acre e o Amazonas, estão na linha da fronteira agrícola comercial. Esses estados tornaram-se pontos estratégicos de investimentos e expansão do agronegócio. Contudo, esse crescimento foi fortemente influenciado pelas condições naturais, nos incentivos financeiros público/privado, nos investimentos técnico-científico-informacional e em infraestrutura da região.

Novas particularidades econômicas surgem no contexto histórico-geográfico da Amazônia brasileira com a expansão do agronegócio, sobretudo em Rondônia que durante duas décadas transformou-se num espaço de produção e exportação de commodities e, com elas, territórios e sociedades amazônicas são subordinadas a um modelo econômico avassalador. $\mathrm{Na}$ esteira desse modelo, a floresta vai dando espaço as pastagens e as monoculturas. Modos de vida, culturas tradicionais, são dilaceradas pela hegemonia do capital agrário que ditam regras e impõem seus mecanismos de dominação.

\section{REFERÊNCIAS}

ALVES, José Luiz. Seagri. Volume exportado por Rondônia neste ano é de 212,2 milhões de toneladas, carne e soja são destaques. 25 de março de 2019. Disponível em: www.RONDÔNIA.ro.gov.br/volume-exportado-por-RONDÔNIA-neste-ano-e-de-2122-milhoes-de-toneladas-carne-e-soja-sao-destaques/. Acesso em: 2 maio 2020.

AMARAL, Januário. Mata virgem: terra prostituta. São Paulo: Terceira Margem, 2004.

ANDRADES; Thiago Oliveira; GANIMI, Rosângela Nasser. Revolução verde e a apropriação capitalista, CES Revista, v. 2, p. 43, p. 56. Juiz de Fora, 2007.

BECKER, B. Amazônia: geopolítica na virada do III milênio. 2. ed. Rio de Janeiro: Garamond, 2007.

CANAL RURAL. Exportações de soja do Brasil foram 4,5\% menores em 2019. Disponível em: www.canalrural.com.br/sites-e-especiais/pro- 


\section{Territorialização, expansão e contradições do agronegócio \\ no espaço agrário de Rondônia}

jeto-soja-brasil/exportacao-do-complexo-soja-recua-45-em-volume-e-144-em-receita/. Acesso em: 2 abr. 2020.

CASTILHO, Ricardo et al. Regiões do agronegócio, novas relações campo-cidade e reestruturação urbana. Revista da Associação Nacional de Pós-graduação e Pesquisa em Geografia (Anpege), p. 265-288, v. 12, n. 18, especial GT Anpege 2016.

CASTRO, Iná Elias; GOMES, Paulo Cesar da Costa; Corrêa, Roberto Lobato (org.) Olhares geográficos: modo de ver e viver o espaço. Rio de Janeiro: Bertrand Brasil, 2012.

Conab. Companhia Nacional de Abastecimento. Acompanhamento da safra brasileira. V. 8. Safra 2020/21. N. 12. Décimo segundo levantamento, setembro, Brasília, 2019, p. 1-97. 2021

COSTA SILVA, Ricardo. G. A regionalização do agronegócio da soja em Rondônia. Geousp (online), São Paulo, v. 18, n. 2, p. 298-312, maio/ago 2014a.

COSTA SILVA, Ricardo. G. Globalização e fragmentação do espaço agrário em Rondônia. Revista de desenvolvimento econômico. Ano XVI, n. 30, BA, 2014b.

COSTA SILVA, R. G.; CONCEIÇÃO, F. S. Agronegócio e campesinato na Amazônia brasileira: transformações geográficas em duas regiões nos estados de Rondônia e Pará. Geographia (UFF), v. 19, p. 54-72, 2017.

COSTA SILVA, R.G. Amazônia das commodities e dos territórios em disputas In: COSTA SILVA, R. G.; LIMA, L. A. P.; CONCEIÇÃO, F. S. (Orgs.) Amazônia: dinâmicas agrárias e territoriais contemporâneas. São Carlos: Pedro \& João Editores, 2018. 337p

CUNHA, Eliaquim Timotéo; MOSER, Lilian Maria. Os projetos de colonização em Rondônia. Revista Labirinto, Ano X, n. 14, dezembro de 2010. DIÁRIO DA AMAZÔNIA: Soja lidera a produção agrícola em Rondônia. Redação Diário da Amazônia. Publicado: 23/11/2019 às 8h40min. Disponível em: www.diariodaamazonia.com.br/soja-lidera-a-producao-agricola-em-RONDÔNIA/. Acesso em: 30 abr. 2020.

DOMINGUES, Mariana Soares; BERMANN, Célio. O arco de desflorestamento na Amazônia: da pecuária à soja. Ambiente \& Sociedade. São Paulo, v. XV, n. 2, p. 1-22. 2012.

ELIAS, Denise. Ensaios sobre os espaços agrícolas de exclusão. Revista Nera, ano 8, n. 8, janeiro/junho de 2006 - ISSN 1806-6755. 


\section{Geografias de Rondônia Território, Fronteira e Educação}

VIEIRA FILHO, J. E. R. (org.) Diagnóstico e desafios da agricultura brasileira. Rio de Janeiro. IPEA, 2019. 340 p.

HAESBAERT, Rogério. Viver no limite: território e mult/transterritorialidade em tempos de in-segurança e contenção. Rio de Janeiro: Bertrand Brasil, 2014.

IBGE. Censo Agropecuário 2017. Rio de Janeiro, 2019, v. 8, p. 1-105.

KAHIL, Samira Peduti; PEREIRA, Mirlei Fachini Vicente. A lógica corporativa do uso do território em Rondônia: o agronegócio da soja na região de Vilhena. Campo-Território, v. 5, n. 10, p. 288-311, ago. 2010. MARTINS, José de Souza. Fronteira: a degradação do outro nos confins do humano. 2. ed. São Paulo: contexto, 2014.

MCMICHAEL, Philip. Estudos camponeses e mudanças agrárias: regimes alimentares e questões agrárias. São Paulo: Unesp, 2016.

MOREIRA, Ruy. Pensar e ser geografia: ensaios de história, epistemologia e ontologia do espaço geográfico. 2. ed. São Paulo: Contexto, 2015. NETO, C. R.; SILVA, F. A. C.; ARAÚJO, L. V. Boletim agropecuário de Rondônia: evolução da produção agropecuária. Junho, 2018. Porto Velho, RO: Embrapa Rondônia, 2019.

NUNES, Dorisvalder Dias. Hidrovia do Madeira: (re)configuração espacial, integração e meio ambiente. Belém, 2004. Tese (Doutorado em Desenvolvimento Sócio-Ambiental) - Núcleo de Altos Estudos Amazônicos, Universidade Federal do Pará.

PAULINO, Eliane T. Por uma geografia dos camponeses. São Paulo. 2. ed. Editora Unesp. 2012, 353 p.

RICARTE, Carlos A. A. A psicosfera do espaço agrário de Vilhena: contradições entre o agronegócio e o campesinato. 2017. Dissertação (Mestrado em Geografia) Fundação Universidade Federal de Rondônia - UNIR. Porto Velho, RO, 167 p.

SANTOS, Carlos. A fronteira do Guaporé. Porto Velho: Edufro, 2007.

SANTOS, Maureen; GLASS, Verena. Altas do agronegócio: fatos e números sobre as corporações que controlam o que comemos. Rio de Janeiro: Fundação Heinrich Böll, 2018. 60 p.

SANTOS, Milton. Por uma outra globalização: do pensamento único a consciência universal. 16. ed. Rio de Janeiro. Record, 2008.

THÉRY, Hervé. Rondônia: mutações de um território federal na Amazônia brasileira. S.l, SK Editora, 2012. 


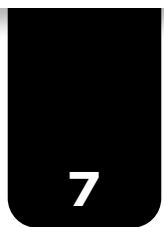

CAFEICULTURA EM RONDÔNIA: CIRCUITO ESPACIAL DE PRODUÇÃO, MODERNIZAÇÃO E SUBORDINAÇÃO ${ }^{1}$

\author{
Tiago Roberto Silva Santos" \\ Ricardo Gilson da Costa Silva**
}

\title{
INTRODUÇÃO
}

Localizado na Amazônia Ocidental, o estado de Rondônia é um exemplo de avanço da fronteira agrícola brasileira sobre a floresta amazônica, incorporando áreas tradicionais na prática extrativista, na produção destinada a suprir demandas do mercado capitalista globalizado. Dentre os produtos introduzidos nessa região amazônica, o café tomou grande importância na transformação do uso espacial rondoniense após o processo de colonização dirigido pelo governo federal, que incentivou intenso fluxo migratório para o estado, resultando em acelerada substituição de áreas de floresta por lavouras de café.

Introduzida pelos imigrantes que chegavam em Rondônia, a cafeicultura teve importante papel social aos colonos, que oriundos de estados produtores de café, traziam suas práticas para a nova terra, permitindo assim sua fixação. Porém, esta atividade não teve somente importante aspecto social, ganhou também protagonismo econômico para o estado, elevando este entre os principais produtores de café do país.

Diante desta relevância da cafeicultura, buscamos neste texto compreender a organização espacial da atividade cafeeira em Rondônia através da análise de sua participação no cenário nacional e internacional através dos agentes responsáveis pela circulação do produto. Além

\footnotetext{
${ }^{1}$ Publicado em: SILVA SANTOS, Tiago Roberto; COSTA SILVA, Ricardo Gilson. Cafeicultura em Rondônia: circuito espacial de produção, modernização e subordinação. Revista Geografia (Londrina), v. 26, n. 2, p. 145. 2017.

" https://orcid.org/0000-0002-7771-5210

" https://orcid.org/0000-0002-3348-9629
} 


\section{Geografias de Rondônia Território, Fronteira e Educação}

disso, propomos uma análise espaçotemporal sobre a produção de café em Rondônia, identificando assim os processos de modernização técnica que esta atividade tem passado e como isso tem refletido na qualidade e produtividade do café. Por fim, propomos uma análise sobre as relações sociais desta produção mais tecnificada, que subordina os agricultores familiares ao capital a partir da formação de uma psicosfera ${ }^{2}$ (Santos, 2014b) voltada à modernização.

Portanto, para atingir tais objetivos, organizamos este trabalho em três partes além desta introdução e das considerações finais.

$\mathrm{Na}$ primeira parte, apontamos como a globalização promove transformações no uso do espaço, formando uma divisão territorial do trabalho a partir da criação de um meio técnico-científico-informacional, o que gera áreas especializadas em produtos específicos e como consequência tem a formação circuitos espaciais de produção. A partir dessa compreensão, buscamos entender através de levantamento bibliográfico e de dados, como está organizado o circuito espacial de produção e o círculo de cooperação da produção do café no Brasil e em Rondônia.

$\mathrm{Na}$ segunda parte apresentamos como tem ocorrido o processo de modernização da cafeicultura em Rondônia, para tanto, utilizamos de uma abordagem espaço temporal, que contribui para a compreensão de como se deu a incorporação do espaço rondoniense à produção voltada ao mercado, bem como a introdução da cultura cafeeira no estado e os avanços técnicos incorporados a esta atividade, melhorando sua qualidade e produtividade.

Por fim na terceira parte fizemos alguns apontamentos sobre as relações sociais e de trabalho na cafeicultura estadual, que é desenvolvida por agricultores familiares, mas que estão sendo inseridos em um ambiente de modernização, ficando sujeitos às exigências do capital industrial em relação à qualidade do produto e inovações técnicas.

Assim, baseado em levantamento bibliográfico e de dados levantados em trabalho de campo, acreditamos conseguir obter um panorama sobre a organização espacial da atividade cafeeira e as relações de mercado e sociais desenvolvidas em Rondônia.

${ }^{2}$ Para Santos (2014b) a psicosfera, está relacionada ao fornecimento de normas, atuando no ramo das ideias e estimulando o imaginário na adoção das regras impostas pelos controladores do sistema produtivo. 


\section{Cafeicultura em Rondônia: circuito espacial de produção, modernização e subordinação}

\section{Circuito espacial de PROdução do CAFÉ EM Rondônia}

O atual momento de globalização é resultado do desenvolvimento histórico de técnicas que promoveram no espaço a formação de um meio técnico-científico-informacional (Santos, 2014b; Santos; Silveira, 2008), possibilitando a dispersão espacial das diversas etapas do sistema produtivo. Assim, a produção deixa de estar concentrada em poucos pontos no planeta, mas, distribuídas, normalmente nos países periféricos, e controladas pelos grandes centros. Baseado nessa lógica, Castells (2000), aponta para a interdependência econômica global, a partir do fim do século XX, através de uma revolução tecnológica, concentrada na informação, sendo esta como fonte de produtividade.

Nesse contexto, o resultado da globalização no mundo é a intensificação da divisão territorial do trabalho, promovendo no espaço a formação de um mosaico de áreas especializadas em ramos produtivos diferentes (Castillo; Frederico, 2010; Silveira, 2011), além disso, nem sempre os locais da produção são os mesmos da industrialização e/ou consumo, sendo necessária a implantação de um conjunto de fixos e flu$\operatorname{xos}^{3}$ (Santos, 2014b) que permitam a mobilidade da produção para onde estão localizadas as indústrias, e somente depois ser distribuída para o consumo.

Como forma de compreender tal dinâmica, Santos (1994, 2014a), Santos e Silveira (2008), Castillo e Frederico (2010), Frederico e Castillo (2004) e Silveira (2011) propõe a análise desse processo através do circuito espacial de produção, uma categoria de análise geográfica que permite analisar a organização espacial através da produção e circulação, material e imaterial, que formam fluxos de bens, capital, informação, normas, objetos técnicos, etc., demonstrando a espacialidade e a articulação do sistema produtivo. Sobre isso, Santos (1994) destaca:

O mundo encontra-se organizado em subespaços articulados dentro de uma lógica global. Não podemos mais falar em circuitos regionais de produção.[...] temos que falar em circuitos espaciais da produção. Estes seriam as diversas etapas pelas

\footnotetext{
${ }^{3}$ Os elementos fixos são os objetos fixados em algum lugar do espaço, permitindo ações que modificam estes lugares conforme os interesses daqueles que o instalaram. Os fluxos são resultados dessas ações, em que o uso do fixo permite maior fluidez do produto no espaço.
} 


\section{Geografias de Rondônia Território, Fronteira e Educação}

quais passariam um produto, desde o começo do processo de produção até chegar ao consumo final. (p. 49)

Baseado neste conceito, apontamos o papel da cafeicultura brasileira, que se destaca no cenário mundial como principal exportador de café (Cecafé, 2016), sendo que sua produção é realizada em várias regiões do território brasileiro, o que resulta na criação de infraestruturas no espaço que possibilitem sua circulação até as indústrias torrefadoras ou os portos para exportação.

Assim, temos no circuito produtivo de café vários agentes dispersos no espaço e responsável por alguma etapa da produção. Santos (1994) alerta que em uma mesma área pode-se ter vários circuitos de produção e também em uma mesma região pode-se ter distintas fases do processo produtivo, como a produção e o beneficiamento, e/ou a industrialização. Porém, isso não é uma regra, visto que, com o aumento da capacidade de circulação material (produto) e imaterial (informações) (Frederico; Castillo, 2004) e da globalização, as distintas etapas do processo não precisam necessariamente estarem próximas.

Com relação ao café, a atividade no Brasil alcançou seu auge durante o século XX, concentrando-se principalmente nos estados do Rio de Janeiro, São Paulo, Paraná e Espirito Santo, que tiveram a implantação ao espaço, de um conjunto de objetos técnicos fixos que contribuíssem para tal atividade, tal qual para seu fluxo, como as indústrias beneficiadoras e armazéns, além das rodovias e ferrovias que ligavam o interior produtor aos portos, inclusive promovendo novas colonizações como no oeste de São Paulo e norte do Paraná, transformando assim o uso do espaço para tal atividade (Ortega; Jesus, 2012).

A partir da década de 1960, buscando melhorias na produção, o Instituto Brasileiro do Café (IBC) criou o Grupo Executivo de Racionalização da Cafeicultura (Gerca), que incentivou a substituição dos cafeeiros tradicionais por outros que permitissem maior produtividade, incorporando à produção, tecnologias da chamada revolução verde (Ortega; Jesus, 2012). No entanto, no Paraná e em São Paulo, grande área da cafeicultura foi substituída por outras culturas, visto que, as condições climáticas geravam inúmeras perdas de produção, principalmente devido às geadas. Com isso a atividade cafeeira passou a dispersar-se pelo território brasileiro, tendo como principais áreas produtoras o sul e sudoeste de Minas Gerais (Frederico; Castillo, 2004; Ortega; Jesus, 2012). Após a dispersão para Minas Gerais, o café ainda expandiu 


\section{Cafeicultura em Rondônia: circuito espacial de produção,}

modernização e subordinação

para Rondônia e também para o oeste da Bahia, ampliando assim a sua abrangência no território nacional (Figura 1). Porém, nem todas as áreas produtoras passaram, desde o início, a fazer parte do circuito espacial de produção do café, pois não estavam interligadas à circulação da produção e nem ao grande capital, tratava-se de produções locais, como o caso de Rondônia durante as décadas de 1970 e 1980, quando o café foi introduzido neste estado, e que possuía mais uma função social, na territorialização do camponês, do que necessariamente econômica.

Figura 5 - Produção de café no Brasil por UF (2019).

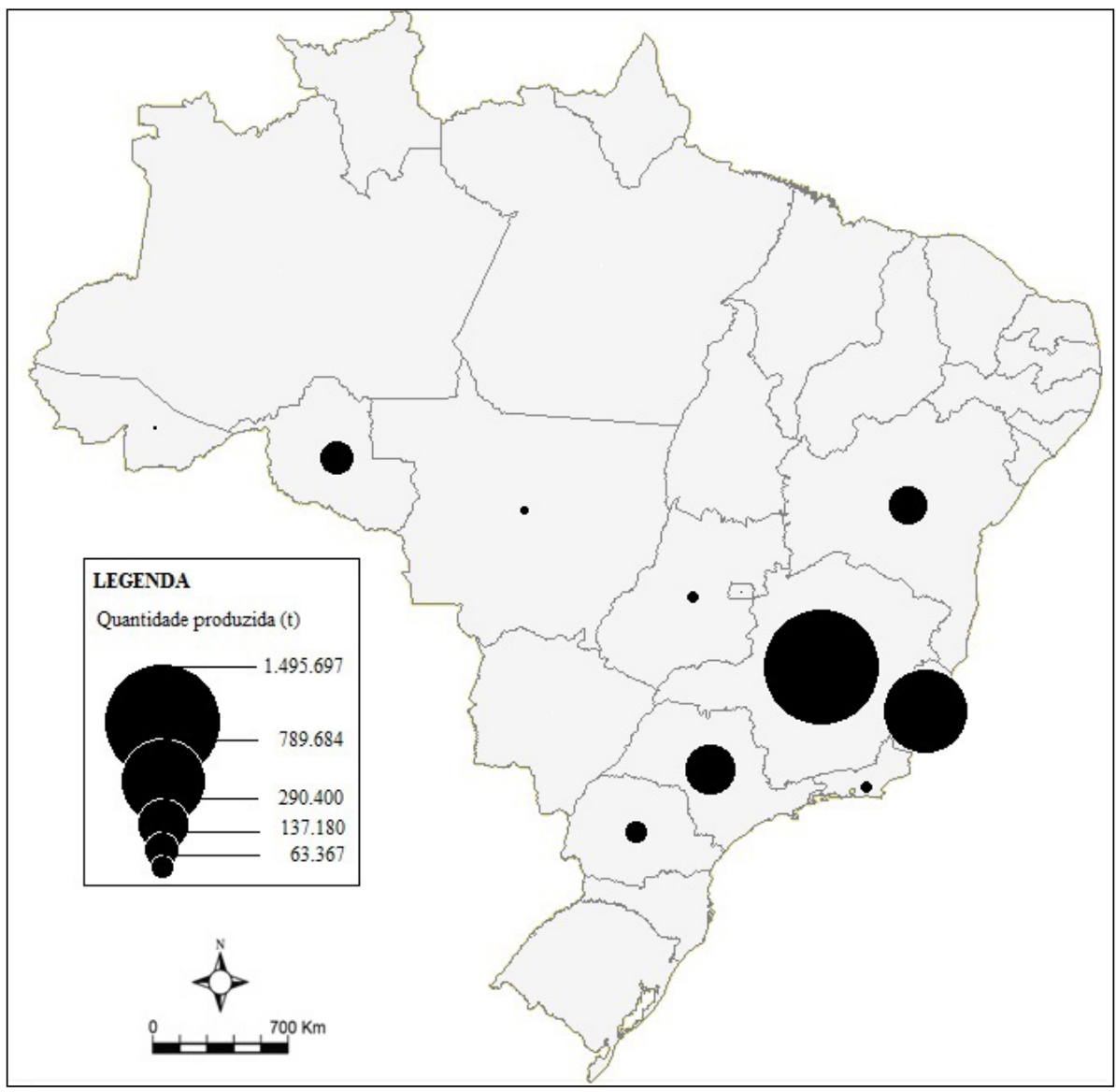

Fonte: IBGE, 2019 (PAM). Org: SANTOS, T. R. S. 


\section{Geografias de Rondônia Território, Fronteira e Educação}

Apesar da desconcentração produtiva do café apresentada na figura 1, identificamos que, o centro industrial dessa atividade, com as principais torrefadoras do país, permaneceu concentrado na região Sudeste e Sul do país, pois, com a implantação de meios técnicos de transporte e comunicação, não era necessário que as indústrias acompanhassem o deslocamento dos parques cafeeiros, principalmente por estes terem expandido para o oeste do país, como no caso de Rondônia, ficando distante dos grandes centros urbanos consumidores, além da distância dos portos para exportação.

Assim, com algumas áreas especializadas na cafeicultura e dispersas pelo território brasileiro, criou-se um fluxo da produção e de informações que articulam todo o processo de industrialização no país, formando o circuito espacial de produção em conjunto com os agentes do círculo de cooperação, sendo este, responsável por interligar as diversas etapas do processo, levando aos agentes participantes, as informações e normas à produção (Silveira, 2011; Frederico; Castillo, 2004), que atendam às exigências do mercado.

Consoante a essas informações, definimos como integrantes do circuito espacial do café: os produtores, associações, capital comercial, armazéns, cooperativas, indústrias de torrefação, exportadores, portos e comércio, seja atacado ou varejo. Assim, temos desde a produção até o consumo, vários agentes envolvidos, porém, todo o processo é subordinado aos interesses dos detentores do capital internacional, neste caso do café, as indústrias multinacionais e os seus investidores.

Portanto, para atender aos interesses desses agentes hegemônicos, normas são criadas para cada setor, de forma a melhorar a qualidade do produto e o lucro dessas empresas, sendo que, os responsáveis por levarem essas regras até os participantes do circuito produtivo, são os agentes do círculo de cooperação, compostos por instituições públicas e privadas, e que através de assistência técnica, pesquisa, articulação de política pública, etc. promovem a difusão das informações, interligando as diferentes etapas e agentes, favorecendo à maior participação no mercado do café, seja em escala nacional ou internacional.

No caso específico de Rondônia, o café integra atualmente o circuito espacial de produção, sobretudo, em escala nacional, fornecendo matéria-prima às principais torrefadoras do país, porém, também tem participação em exportação, principalmente para: México, Bolívia, Espanha e Alemanha (MDIC, 2015), que são realizadas, principalmente, por corporações multinacionais que instalaram filiais no estado, 


\section{Cafeicultura em Rondônia: circuito espacial de produção, modernização e subordinação}

em Cacoal como a EISA - Interagrícola, do grupo ECOM trading; a Louis Dreyfus, grupo francês; e a indiana Ollan Coffee. A atração dessas empresas é resultado da atuação conjunta de diversos agentes do círculo de cooperação que tem atuado na melhoria da produtividade e qualidade do café rondoniense.

Segundo Veneziano (1996) a dificuldade de negociação do café rondoniense se dava dentre muitos aspectos pela: distância dos grandes centros de consumo, industrialização e exportação; além do baixo uso tecnológico na produção; cooperativas fortes; linhas de créditos especiais; má qualidade do produto e por fim o pequeno conhecimento de mercado por parte dos produtores, dessa forma, apesar de Rondônia possuir um importante parque cafeeiro no país, a produção não ocorria de forma organizada, o que dificultava sua participação no circuito espacial de produção do café, inclusive, um dos destaques apontados pelo autor era a distância do estado em relação aos principais centros cafeeiros do país, o que demonstra a dificuldade da circulação tanto material como imaterial, além do pequeno incremento tecnológico na produção, resultando em produto de baixa qualidade.

Para solucionar tais problemas, as instituições do círculo de cooperação começaram a atuar, como no caso da Embrapa/RO, que levou em torno de 25 anos para lançar a cultivar BRS Ouro Preto ${ }^{4}$ que apresenta maior produtividade. Porém, a grande participação desses agentes começou, principalmente a partir de 2010, com inovações técnico-cientificas para a produção de café, como: maior assistência técnica ao produtor com novidades no manejo da planta, transferência de conhecimento de mercado ao agricultor e suporte financeiro por parte de instituições financeiras e do governo estadual.

Diante dessa organização do setor produtivo de café em Rondônia e sua participação no circuito espacial de produção, o resultado tem começado a aparecer em números. Segundo o site oficial do governo do estado, baseado em dados do Ministério do Desenvolvimento, Indústria e Comércio Exterior (MDIC), entre as safras de 2014 e 2015, houve um aumento de $166 \%$ na exportação do café rondoniense, além de maior parte da produção estadual ser vendida para Minas Gerais, Paraná, Rio de Janeiro e São Paulo, ficando entre os 5 maiores produtores de café do

${ }^{4}$ Informação obtida através do Sr. Alexandro Lara Teixeira, secretário executivo do Comitê Técnico Interno da Embrapa/RO, através de entrevista concedida ao autor em 6 de jul. de 2016. 


\section{Geografias de Rondônia Território, Fronteira e Educação}

país, além de ser o segundo maior produtor de café conilon (Rondônia, 2015). Isso é possível graças ao aumento da produtividade e melhor circulação da produção no território. Tal resultado também é resposta às exigências impostas pelas indústrias de café em relação à qualidade.

Contudo, vemos em Rondônia a constituição de um circuito espacial de produção de café integrando-se mais fortemente aos ditames do capital internacional na produção, de forma a aumentar seu poder de exportação, promovendo no espaço a introdução de objetos fixos e que também permitem o fluxo, além da constituição de círculos de cooperação, que atuando de forma conjunta, interligam os agentes do circuito de produção e repassam as informações, normas e técnicas definidas pelos agentes hegemônicos responsáveis pela industrialização e comércio do café.

\section{MODERNIZAÇÃO CAFEEIRA E A TRANSFORMAÇÃO DO ESPAÇO EM RONDÔNIA}

Como visto, o estado de Rondônia tem se apresentado com grande relevância entre os estados produtores de café, integrando-se, atualmente, ao circuito espacial de produção devido às melhorias em produtividade e qualidade apresentadas, sobretudo pela incorporação técnico-científica nas práticas agrícolas, através do desenvolvimento de pesquisas e de adoção de inovações no manejo da planta.

A incorporação da ciência ao processo produtivo promove constantes transformações no espaço, deixando este, cada vez mais tecnificado, instrumentalizado e trabalhado, assim "a agricultura passa, então, a se beneficiar dos progressos científicos e tecnológicos, que asseguram uma produção maior sobre porções de terra menores" (Santos, 1994, p. 43). Portanto, a melhor produtividade e qualidade do café rondoniense é resposta da transformação deste espaço produtivo, que apesar de ser rural, é cada vez menos natural.

Para compreender como ocorre esta modernização do processo produtivo de café, e em consequência do espaço rondoniense, vimos ser necessário entender como se constituiu esta cultura agrícola no estado, pois segundo Santos (2014a) o espaço é composto por elementos de vários momentos históricos, em que, alguns são totalmente substituídos e outros resistem ao tempo, coexistindo elementos de períodos diferentes, demonstrando assim a evolução. Portanto, o espaço agrícola encontrado hoje, é fruto de processos históricos que o constituíram. Dessa forma "a noção de espaço é assim inseparável da ideia de sistemas de 


\section{Cafeicultura em Rondônia: circuito espacial de produção, modernização e subordinação}

tempo" (Santos, 2014a, p. 36). Nesse sentido, compreender os processos históricos da constituição do estado de Rondônia e a introdução da cafeicultura em seu território se mostra importante para entender o atual momento da produção de café e sua participação no circuito espacial de produção.

O estado de Rondônia passou por acelerado processo de ocupação e urbanização a partir do início da década de 1970, sendo que, este fluxo reduziu somente no início da década de 1990. Tal processo foi resultado de um projeto do governo federal com intenção em colonizar áreas da região amazônica com baixo índice demográfico, avançando, portanto, a fronteira agrícola do país, e resultando no choque entre populações com tempos históricos distintos (Martins, 2014). Nesse caso, o tempo lento da natureza e de quem nela sobrevive, encontra-se com o tempo rápido ou tempo angustiado do capital e do mercado (Loureiro, 2009; Santos, 2014b), resultando em uma relação espaço-tempo heterógena, formado por grupos de pensamentos e costumes diferentes.

O tempo lento representa o uso extrativista do espaço, em que o que impera é o tempo da natureza, sem a correria da produção voltada ao comércio. Essa lentidão demonstra o espaço natural (Santos, 1994, 2014a, 2014b), com pouca introdução técnica no desenvolvimento de trabalho e em sua transformação. Portanto, nesse choque entre os diferentes tempos, o predomínio do espaço natural em Rondônia passa a ser incorporado aos ditames da produção voltada ao mercado, tornando-se em um meio técnico (Santos, 2014b; Silva 2014, 2015). Segundo Becker (2009), projetos de expansão sobre a Amazônia, são financiados pelo capital internacional, incluindo áreas isoladas à lógica de mercado, além de demonstrar uma disputa territorial, em que os agentes internacionais demonstram seu poder de influência sobre a Amazônia, um dos únicos eldorados ainda a serem explorados (Becker, 2005, 2009).

Dessa forma, Rondônia experimentou grande transformação espacial com a implantação do projeto Polonoroeste, financiado pelo Banco Mundial e que tinha como objetivo a pavimentação da rodovia BR-364, que interliga Porto Velho a Cuiabá. Ainda junto a pavimentação da rodovia, foram criados pelo Incra (Instituto Nacional de Colonização e Reforma Agrária) assentamentos, para receber as milhares de famílias que migravam de vários estados em busca de terras para viver e produzir (Silva, 2014).

Os assentamentos rurais foram fundamentais na mudança da dinâmica espacial rondoniense, substituindo o meio natural de práticas 


\section{Geografias de Rondônia Território, Fronteira e Educação}

extrativistas, para um meio técnico, de incorporação de recursos para produção e territorialização das famílias às terras recém-recebidas pelo projeto de colonização do Incra. Ainda que com pouca estrutura, formaram-se às margens da rodovia, centros urbanos ligados às áreas destinadas aos assentamentos, principalmente na parte central de Rondônia, onde os Projetos Integrados de Colonização (PICs) Ouro Preto, Ji-Paraná e Adolfo Rohl assentaram 13.500 famílias nas áreas das cidades de Ouro Preto D’Oeste, Ji-Paraná, Cacoal, Presidente Médici, Rolim de Moura, Pimenta Bueno, Espigão D’Oeste e Jaru (Binsztok, 2006).

Rondônia se afigura como um caso interessante no cenário agrário brasileiro, dado que todo seu processo recente de colonização foi desencadeado por iniciativa oficial, contemplando camponeses expropriados. Implantou-se no espaço RONDÔNIAno uma estrutura agrária que objetivava a produção agrícola, no intuito de substituir a tradição extrativista local. (Santos, C. 2001, p. 8)

Assim, o interior de Rondônia ficou caracterizado pela introdução da agricultura familiar policultora, responsável pela produção de diversos itens em seus recém-recebidos lotes. Um dos principais produtos introduzidos pelos colonos, principalmente da parte central de Rondônia, foi o café, e isso não se deu de forma aleatória, mas conforme apontam alguns autores, dois fatores foram primordiais para a implantação dessa atividade no estado: o costume agrícola e a possibilidade de territorialização do migrante camponês (Binsztok, 2006; Marcolan et al., 2009).

No primeiro caso, temos que, grande parte dos migrantes que chegou em Rondônia, eram oriundos, principalmente, do Espírito Santo e do Paraná, que são importantes estados produtores de café no país. Portanto, esses colonos tinham o costume do trato do café por já terem trabalhado com essa cultura agrícola em seu estado de origem (Binsztok, 2006). Já o segundo aspecto importante para a introdução do café em Rondônia, é que, trata-se de uma cultura perene, portanto, o produtor ao introduzir essa atividade demonstrava a sua intenção de instalar-se na propriedade, o que facilitava o recebimento definitivo de posse de terra pelo Incra (Marcolan et al., 2009), além, é claro, de contar com o trabalho de toda a família, visto que se trata de uma atividade que exige grande quantidade de mão de obra. 


\section{Cafeicultura em Rondônia: circuito espacial de produção, modernização e subordinação}

Assim, vemos que, o Incra distribuía a terra para os produtores rurais sem terras oriundos de outras regiões do país, porém, obrigava o colono a desmatar e produzir para poder então receber o título definitivo da terra, criando neste espaço uma integração ao mercado capitalista. Destarte, o que ocorreu em Rondônia foi um processo de avanço da fronteira agrícola sobre um espaço natural, incluindo este à lógica de mercado através de um processo de modernização técnica, substituindo a atividade extrativista em uma intensificação da atividade agropecuária.

Portanto, com esta inclusão da lógica de mercado na produção agropecuária de Rondônia, a cafeicultura conseguiu relevância em algumas regiões do estado, principalmente na parte central. Assim, a atividade que inicialmente tinha um papel social, na territorialização do camponês, passou a ter importância econômica, alcançando expressivos índices, em área destinada à produção durante a década de 1990 e atingindo mais de 220 mil hectares em 2001 (IBGE, 2016).

Apesar deste crescimento da área plantada de café em Rondônia durante a década de 1990 e início dos anos 2000, a condição técnica dessa atividade não acompanhava a intensificação tecnológica da agricultura brasileira que já havia ocorrido no pós Segunda Guerra, pois, por se tratar de uma nova área agrícola, o processo de modernização dessa região ocorreu tardiamente, pois a modernização espacial não ocorre em todos os lugares ao mesmo tempo (Santos, 2014a). Somente a partir de 2010, através dos agentes do círculo de cooperação, que se intensificou as ações em torno da modernização técnica da cafeicultura em Rondônia.

Atualmente, há em Rondônia um intenso processo de difusão do pacote tecnológico para a cafeicultura, principalmente através da atuação do poder público estadual com a Emater/RO, Secretaria de Agricultura (Seagri), Câmara Setorial do Café (Sujeita à Seagri), mas também com a participação da Embrapa no desenvolvimento de novas pesquisas de cultivar e manejo, além de empresas privadas que apoiam o desenvolvimento tecnológico do setor cafeeiro rondoniense. $\mathrm{O}$ resultado desse processo é a artificialização da produção de café, com novas técnicas de manejo, como: análise do solo; calagem; adubação; uso de agrotóxicos; e poda e desbrota; além da instrumentalização com novos objetos que até pouco tempo eram estranhos ao meio rural rondoniense, como a irrigação artificial (Figura 2). Dessa forma, a produção passa a atender as normas do capital industrial, resultando em uma participação com maior escala de abrangência, atuando no cenário nacional e internacional. 


\section{Geografias de Rondônia Território, Fronteira e Educação}

Figura 2 - Cafezal irrigado, novos objetos técnicos introduzidos ao espaço rural de Rondônia.

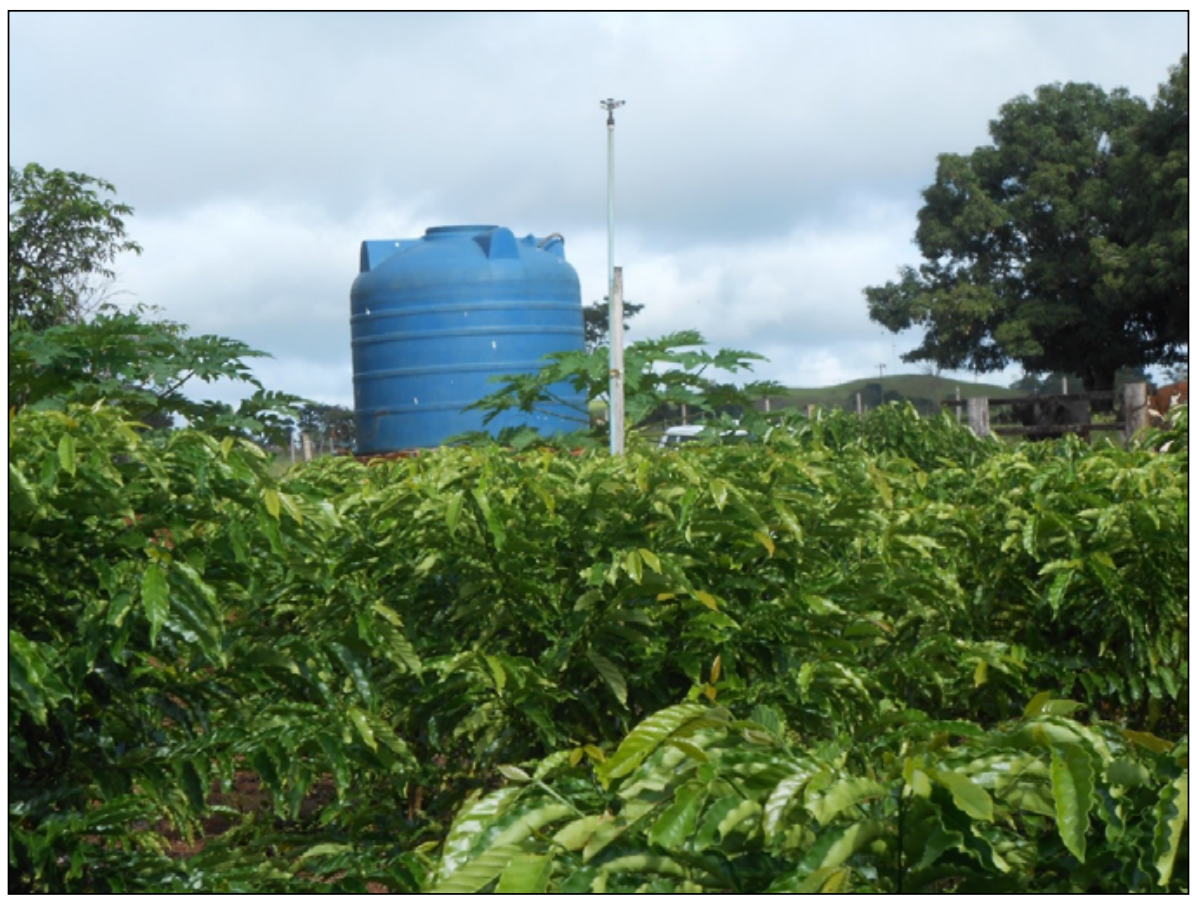

Fonte: SANTOS, T. R. S.

Além das inovações técnicas, a modernização da cafeicultura rondoniense tem como principal instrumento a substituição de produções tradicionais, plantadas através de semente e sem manejo; por mudas clonais, criadas a partir do cruzamento genético de diversas plantas com boa resistência a pragas e às intempéries climáticas, apresentando boa produtividade, o que possibilita os ganhos do capital ao obter melhor aproveitamento espacial. Dessa forma, o entendimento por modernização agrícola acompanha o que aponta Graziano Neto (1985), em que, não são somente as inovações técnicas que representam uma produção moderna, mas também o interesse capitalista na tecnificação da atividade, sendo que, a introdução de novos objetos no espaço produtivo tende a beneficiar o controle do capital sobre aquela porção do espaço.

Dessa forma, o capital industrial, através da influência dos agentes do círculo de cooperação, incentiva os agricultores familiares na ado- 


\section{Cafeicultura em Rondônia: circuito espacial de produção, modernização e subordinação}

ção de mudas clonais que apresentem maiores índices de produtividade. O único exemplo de cultivar clonal certificado em Rondônia é o BRS Ouro Preto, criado pela Embrapa e que apresenta bons resultados adaptados às condições de relevo e clima do estado, com rendimento de 70 sacas por hectare, e em caso de irrigação, pode atingir mais de 110 sacas por hectare (Embrapa, 2015), por questão de comparação, a produção em sistema tradicional, através de semente e sem manejo da planta, apresenta um rendimento de 11 a 12 sacas por hectare (Oliveira; Araújo; Araújo, 2011). Apesar de ser o único certificado, o BRS Ouro Preto não é o único cultivar clonal plantado em Rondônia, pois, em razão da demora das pesquisas para criação de um clonal de Rondônia, viveiristas fizeram seu próprio cultivar através do cruzamento das plantas que apresentassem melhor desempenho, resultando em diversos tipos de plantas clonais no estado.

Destarte, percebemos que a introdução tecnológica ao processo produtivo de café em Rondônia, através dos agentes do círculo de cooperação tem chegado aos produtores, o que tem permitido grande avanço na produtividade do estado, além de maior relevância desta produção no cenário nacional, devido, principalmente, a melhor qualidade da produção, o que resulta também em melhores rendimentos aos envolvidos na cafeicultura. Além disso, com a intensificação tecnológica na agricultura, o espaço torna-se mais artificializado, com a presença de inúmeros objetos técnicos que contribuam para uma produção mais acelerada, o que atende aos interesses do mercado capitalista.

\section{As RELAÇÕes de TRABALHO Na CAFEICULTURA DE RoNDÔNIA A PARTIR DA MODERNIZAÇÃO TÉCNICA}

Historicamente a cafeicultura apresentou importante papel social ao contribuir para a territorialização do migrante camponês recém-chegado em seu lote em Rondônia. Além disso, permitia o trabalho a todos os integrantes da família devido à necessidade de grande mão de obra exigida pela atividade, evitando o êxodo rural dos mais jovens e mantendo a sucessão familiar no campo.

A introdução da atividade cafeeira em Rondônia não teve somente este papel social, de contribuir para a permanência das famílias no campo, mas também tratou-se de uma opção cultural daqueles que chegavam às novas terras. Dessa forma, apesar do início da integração da região ao mercado capitalista, os colonos conseguiam ter autonomia 


\section{Geografias de Rondônia Território, Fronteira e Educação}

na escolha de sua produção, pois essa não estava subordinada ao circuito superior da economia, tendo sua abrangência em escala local.

No decorrer do tempo, a atividade cafeeira começou a alcançar maiores escalas produtivas, o que chamou a atenção do mercado nacional, porém, ainda com baixa tecnologia não atendia todas as exigências de qualidade, resultando em preços mais baixos, o que não gerava grandes impactos econômicos aos produtores, visto que a maioria dos cafezais já havia sido implantados há bastante tempo e não proporcionava muitos gastos a estes.

Recentemente, a cafeicultura de Rondônia tem passado por um intenso processo de modernização técnica em seu desenvolvimento, principalmente, através da atuação dos agentes do círculo de cooperação, o que tem levado os produtores familiares a subordinarem-se ao capital comercial e industrial.

Graziano da Silva (1981) aponta sobre a importância da introdução tecnológica como forma do capital controlar o processo produtivo, além de possibilitar maior lucro sobre a produção. $\mathrm{O}$ autor aponta ainda que a modernização gera a subordinação do produtor ao capital, devido à necessidade de atender às suas exigências. Acompanhando essa colocação, Santos e Silveira (2008), complementam apontando para o uso corporativo do espaço, em que, o uso das relações de trabalho não-capitalistas, é utilizado em favor da extração de renda pelas grandes corporações detentoras do capital industrial ao sujeitar os agricultores às inovações técnicas e financiamentos, incorporando-os à lógica do mercado, sendo esses, os mais vulneráveis dentro do circuito produtivo.

Nesse sentido, o processo de modernização ocorre através de um processo vertical (Santos, 2014b), em que, os agentes controladores do processo, que estão na parte superior da economia, impõem suas regras, e para manter-se no circuito econômico, o agricultor, que está na base do processo, é obrigado a seguir, caso contrário não terá comprador para seu produto e acabará sendo excluído do mercado. Dessa forma, o território é dominado pelo capital, que cria as normas e as dissemina através dos agentes do círculo de cooperação, que levam as informações até o agricultor, incentivando-o a atender as exigências.

Em relação à comercialização do café, a política neoliberalista do fim da década de 1980 e início de 1990 promoveu a desregulamentação estatal do mercado, com o fim do Acordo Internacional do Café (AIC), em que, o controle das negociações passaram, do protecionismo aos produtores, para a exploração pelos compradores (Frederico, 2013). 


\section{Cafeicultura em Rondônia: circuito espacial de produção, modernização e subordinação}

Para exemplificar tal situação, entre os anos de 1970 e 1990, os países produtores de café, subdesenvolvidos, retinham metade do valor total das negociações com as empresas multinacionais, seja torrefadoras ou exportadoras de grãos. Desse valor, em torno de $30 \%$ ficava com o produtor, ou seja, este era um importante agente dentro das tomadas de decisões sobre o mercado do café. Porém, a partir do fim do AIC, em 1989, os países importadores de café passaram a ficar com $75 \%$ da renda obtida na negociação, enquanto países produtores somente com $25 \%$, e desses, somente $13 \%$, aproximadamente, passou a ficar com os produtores. Dessa forma, com a regulação do preço de mercado nas mãos do comprador, o agricultor ficou exposto às lógicas globais do mercado capitalista, perdendo seu poder de influência (Frederico, 2013).

Diante dessa condição do mercado do café, para manter-se na atividade, o agricultor é obrigado a adaptar-se às exigências impostas pelos agentes hegemônicos, investindo em modernização tecnológica para aumentar a produtividade e a qualidade. Porém, por tratar-se, em sua grande maioria, de agricultores familiares descapitalizados, estes recorrem ao crédito rural para implantar em seus estabelecimentos o chamado "pacote tecnológico", no entanto, mesmo sendo assistidos pela Emater, estão sujeitos a mudanças de cenário que os prejudique, como: intempéries climáticas, doenças e pragas na plantação, oscilações do preço do produto na bolsa de valores, etc. Assim, caso ocorra algum problema no momento da produção, o único a sofrer as consequências é o produtor, que não conseguirá pagar o investimento e ficará ainda mais sujeito ao mercado.

No caso específico de Rondônia, criou-se uma psicosfera (Santos, 2014 b) em torno da melhoria tecnológica do café e dos possíveis rendimentos a serem extraídos, principalmente, nas regiões produtivas de café no estado: Região de Cacoal, conhecida como 'Capital do Café'; Região da Zona da Mata e Vale do Guaporé, conhecida como a região de investimento tecnológico avançado; e a Região de Machadinho D'Oeste, frente de avanço da cafeicultura para o norte do estado (Santos; Silva, 2016) (Figura 3). 


\section{Geografias de Rondônia Território, Fronteira e Educação}

Figura 3 - Regiões Produtivas de Café em Rondônia.

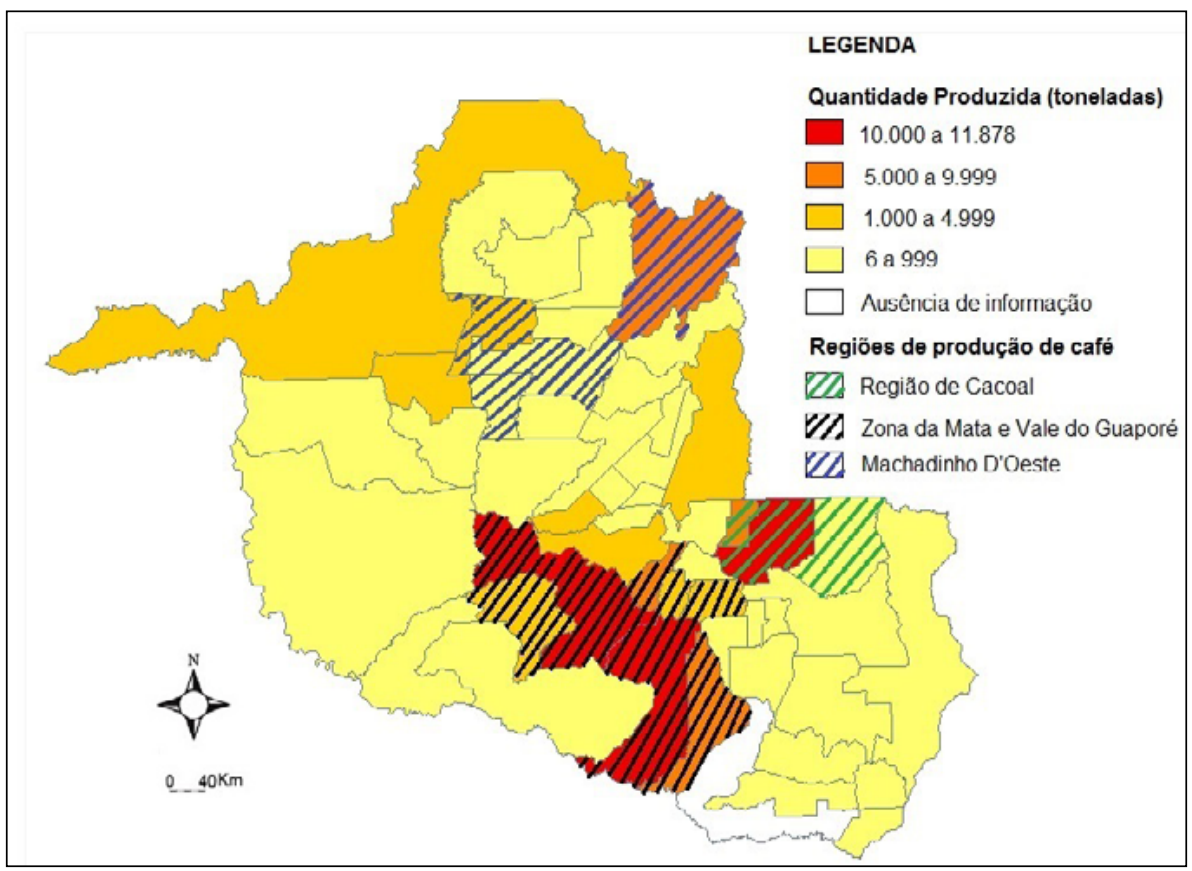

Fonte: IBGE, 2016 (PAM). Org. SANTOS, T. R. S.

Para incentivar a adoção das inovações para o setor, o governo do estado tem investido em uma vitrine tecnológica, para demonstrar ao agricultor as melhorias para a produção, além de fornecer calcário e em alguns casos mudas, além da assistência técnica. Esse conjunto de ações pelo poder público, tem incentivado maior adesão, por parte dos produtores, à cafeicultura modernizada. Além deste incentivo, o anúncio em março de 2015 de que a Nestlé está interessada na compra do café rondoniense aumenta ainda mais a expectativa dos produtores em conseguir bons negócios em relação a esta produção (Rondônia, 2015), ou seja, através de mecanismos de propagandas e políticas públicas, o agricultor está sendo incentivado a adotar uma produção mais modernizada e adaptada às regras do capital.

Neste caso o governo do estado está agindo como um agente do capital, estimulando a produção para o mercado internacional. Além disso, o produtor de café, estimulado pela propaganda de comercialização com a Nestlé e outras indústrias ou exportadoras, acaba por acei- 


\section{Cafeicultura em Rondônia: circuito espacial de produção, modernização e subordinação}

tar sua subordinação às normas impostas. Como exemplo, apontamos a palestra realizada pelo representante da Nestlé, Pedro Malta, no dia 10 de abril de 2015, na Câmara Municipal de Cacoal, durante o evento de lançamento da lei n. 3.516, de 17 de março de 2015, que instituiu o dia do início da colheita do café em Rondônia. Nesta ocasião, o palestrante questionou o uso de várias mudas clonais pelos produtores e os seus métodos de secagem do café, apontando para a necessidade de um padrão que deve ser estipulado pela empresa. Assim, o produtor fica responsável por promover tais mudanças e se sujeitar as normas impostas caso queira vender a sua produção para esta empresa. Desta mesma maneira, outras empresas atuam apontando aos produtores suas normas e sujeitando os mesmos à sua dinâmica de mercado.

Portanto, o café em Rondônia não tem somente uma importância social ao agricultor familiar, mas também é um importante produto em geração de renda à família, no entanto, a introdução tecnológica imposta à cafeicultura de forma vertical, através do círculo de cooperação, tem tornado o cafeicultor um agente subordinado do capital industrial, em que, o interesse de vários agentes envolvidos no circuito espacial de produção acaba por sujeitar os produtores aos ditames do agronegócio do café, promovendo uma organização espacial cada vez mais artificializada, com a introdução de objetos técnicos ao sistema produtivo.

Segundo Frederico e Barone (2013), uma das formas de eliminar essa subordinação ao capital e participar mais efetivamente do circuito espacial produtivo, seria eliminar intermediários entre a produção, industrialização e o consumo, sendo que, para conseguir isso, seria necessário uma organização coletiva, através de cooperativas ou associações que contribuíssem na negociação da safra de forma mais justa com a indústria torrefadora, ou até mesmo com a instalação de agroindústrias do café no espaço rural rondoniense, de forma que conseguisse uma fatia do mercado e não estivesse sujeito aos mandos do capital hegemônico nesse setor. No entanto, a organização em associações rurais ainda é deficiente, apenas contribuindo com a possibilidade de uso dos maquinários e para beneficiamento do café, sem interferir na negociação da safra do agricultor. Assim, com a comercialização individual, esses agricultores estão cada vez mais subordinados aos valores pagos pelo capital. 


\section{Geografias de Rondônia Território, Fronteira e Educação}

\section{CONSIDERAÇÕES FINAIS}

A cafeicultura é uma importante atividade agrícola desenvolvida em Rondônia e com importância no cenário nacional, dessa forma este trabalho buscou uma abordagem para compreender as dinâmicas espaciais e sociais promovidas a partir do desenvolvimento desta cultura no estado.

Com o advento da globalização e as melhorias nos meios de transportes e de comunicação, intensificou-se a divisão territorial do trabalho e consequentemente as especializações produtivas, ficando assim as várias etapas da produção espalhadas pelo espaço, resultando em maior circulação, tanto material como imaterial. Essa dinâmica passou a ocorrer na cafeicultura de Rondônia nos últimos anos, por ser uma área que foi recentemente integrada às lógicas capitalistas de produção voltadas ao mercado.

Com a introdução técnico-científica no meio produtivo e a melhoria de qualidade e produtividade, Rondônia passou a integrar o circuito espacial de produção de café, participando na base desse circuito através da participação dos produtores e do capital comercial, que são os responsáveis por intermediar o produto local com as grandes indústrias torrefadoras multinacionais, localizadas, principalmente, no Sul e Sudeste brasileiro. Além disso, participa no fornecimento de matéria-prima para o exterior através da exportação, que apesar de pequena, tem atraído corporações mundiais para o estado.

A participação no circuito de produção do café é possível graças as articulações dos agentes responsáveis pelo círculo de cooperação, que integram as diversas etapas da produção através de pesquisas de melhorias no cultivar, assistência técnica, financiamento ou até mesmo através dos incentivos promovidos pelo governo do estado.

As melhorias inseridas na modernização do parque cafeeiro de Rondônia elevaram sua produção, ficando entre os cinco estados com maior safra no país, além de segundo maior do café tipo conilon. Tais melhorias no cultivar atendem aos interesses dos principais agentes do circuito de produção de café, o que permite que o produto seja comercializado com grandes indústrias do ramo, além de aumentar as exportações do produto.

Porém, o resultado da introdução científica na produção de café não resulta somente em aspectos econômicos, para haver a circulação do produto, é necessária a implantação de objetos ao espaço, tornando este 


\section{Cafeicultura em Rondônia: circuito espacial de produção, modernização e subordinação}

mais artificializado e integrado ao tempo acelerado do capital, diferente do tempo lento do espaço natural ao qual Rondônia pertencia até o projeto de colonização na década de 1980.

A cafeicultura de Rondônia também apresenta um papel social e cultural para o agricultor familiar, que teve nessa atividade a sua territorialização na região. No entanto, com a modernização técnica dessa atividade, os agricultores familiares precisam se integrar ao mercado capitalista, produzindo cada vez mais e com melhor qualidade, adotando as técnicas exigidas. Porém, como não são capitalizados, necessitam recorrer ao crédito bancário, o que o deixa vulnerável às oscilações do mercado futuro das bolsas de valores, além da possibilidade de intempéries climáticas prejudicar suas produções, sendo eles os únicos a correrem o risco de perdas.

Há assim uma subordinação do trabalhador ao capital, através de normas impostas de forma vertical, em que o trabalhador ajusta suas produções e o seu espaço agrícola às regras exigidas pelos agentes hegemônicos. Por outro lado, os próprios agricultores não conseguem identificar essa subordinação, e consequentemente, acabam não se organizam coletivamente de forma a alcançar maior protagonismo dentro do circuito produtivo, o que os mantém reféns aos ditames do capital industrial.

Destarte, vemos que a atividade cafeeira no estado de Rondônia, tem visado a modernização, de forma a manter-se com importância no circuito espacial de produção em escala nacional e até mesmo alcançar o cenário internacional. Porém, esse processo é resultado da atuação dos agentes do círculo de cooperação, que atuam em favor do mercado globalizado, promovendo transformações espaciais no setor agrícola rondoniense, que cada vez mais torna-se artificializado, além de subordinar a agricultura familiar as regras dos agentes hegemônicos, controladores do capital; ampliando, assim, o uso do espaço ao mercado globalizado.

\section{Agradecimentos}

Agradecimento à Capes pela disponibilização de bolsa de estudos, e ao Instituto Federal de Rondônia pelo afastamento das atividades para dedicação exclusiva à capacitação. 


\section{Geografias de Rondônia Território, Fronteira e Educação}

\section{REFERÊNCIAS}

BECKER, B. K. Geopolítica da Amazônia. Estudos Avançados, São Paulo, v. 53, n. 19, p. 71-86, 2005. Disponível em: www.revistas.usp.br/ eav/article/view/10047. Acesso em: 5 nov. 2015.

BECKER, B. K. Amazônia: Geopolítica na virada do III milênio. Rio de Janeiro: Garamond, 2009.

BINSZTOK, J. Agricultura familiar na Amazônia: o contexto da cafeicultura no centro de Rondônia. Geografias, Belo Horizonte, v. 2, n. 1, p. 22-33, jan./jun. 2006. Disponível em: www.cantacantos.com.br/revista/ index.php/geografias/article/view/14. Acesso em: 17 set. 2014.

CASTELLS, M. A sociedade em rede. Tradução de Roneide Venâncio Majer com colaboração de Klauss Brandini Gerhardt. 8. ed. São Paulo: Paz e Terra, 2000. v. 1.

CASTILLO, R.; FREDERICO, S. Espaço geográfico, produção e movimento: uma reflexão sobre o conceito de circuito espacial produtivo. Sociedade \& Natureza, n. 3, v. 22, Uberlândia, dez. 2010, p. 461-474. Disponível em: www.seer.ufu.br/index.php/sociedadenatureza/article/ view/11336. Acesso em: 18 ago. 2015.

CECAFÉ, Conselho dos Exportadores Mundiais de café do Brasil. Exportações mundiais. Out. 2016. Disponível em: www.cecafe.com.br/ dados-estatisticos/exportacoes-mundiais/. Acesso em: 2 fev. 2017.

EMBRAPA. Nova cultivar de café tem potencial para mudar realidade do campo na Amazônia. Embrapa, 2015. Disponível em: www.embrapa. br/noticia/5389631/nova-cultivar-de-cafe-tem-potencial-para-mudar-realidade-do-campo-na-amazonia. Acesso em: 27 nov. 2015.

FREDERICO, S. Lógica das commodities, finanças e cafeicultura. Boletim Campineiro de Geografia, v. 3, n. 1, Campinas, 2013. Disponível em: http://agbcampinas.com.br/bcg/index.php/boletim-campineiro/article/view/91. Acesso em: 18 ago. 2015.

FREDERICO, S.; BARONE, M. Circuito espacial produtivo e círculos de cooperação do café fairtrade: análise da associação dos agricultores familiares do córrego D'antas (Assodantas), Poços de Caldas/MG. In:

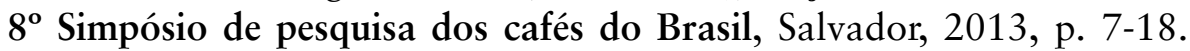
Disponível em: www.sbicafe.ufv.br/handle/123456789/3377. Acesso em: 18 ago. 2015. 
Cafeicultura em Rondônia: circuito espacial de produção, modernização e subordinação

FREDERICO, S. e CASTILLO, R. Circuito espacial produtivo do café e competitividade territorial no Brasil. Ciência Geográfica, v. 10, n. 3, Bauru, 2004.

GRAZIANO DA SILVA, J. Progresso técnico e relações de trabalho na agricultura. São Paulo: Hucitec, 1981.

GRAZIANO NETO, F. Questão agrária e ecologia: crítica da agricultura moderna. São Paulo: Brasiliense, 1985.

IBGE. Pesquisa Agrícola Municipal, 2016. Disponível em: www.sidra. ibge.gov.br. Acesso em: 15 jan. 2016.

IBGE. Pesquisa Agrícola Municipal, 2019. Disponível em: www.sidra. ibge.gov.br. Acesso em: 15 set. 2020.

LOUREIRO, V. R. Amazônia no séc. XXI: de fronteira econômica do país a fronteira do mundo. In: A Amazônia no séc. XXI: as novas formas de desenvolvimento. São Paulo: Empório do Livro, 2009, p. 67-86.

MARCOLLAN, A. L. et al. Cultivo dos cafeeiros Conilon e Robusta para Rondônia. 3. ed. Porto Velho: Embrapa Rondônia: Emater-RO, 2009.

MARTINS, J. de S. Fronteira: a degradação do outro nos confins do humano. São Paulo: Contexto, 2. ed., 2014.

OLIVEIRA, S. J. de M., ARAÚJO, L. V., ARAÚJO, T. G. Avaliação econômica em sistemas de produção de café em Rondônia. In: Simpósio de pesquisa dos cafés do Brasil, 7, 2011, Araxá, Anais...Consórcio pesquisa café, p. 1-5. Disponível em: www.sapc.embrapa.br/arquivos/consorcio/ spcb_anais/simposio7/51.pdf. Acesso em: 20 abr. 2015.

ORTEGA, A. C. e JESUS, C. M. de. Café e território: A Cafeicultura No Cerrado Mineiro. Campinas: Alínea, 2012

RONDÔNIA. Nestlé quer comprar café de Rondônia, primeiro produtor da região Norte, Seagri, 2015. Disponível em: www.RONDÔNIA. ro.gov.br/2015/03/45928/. Acesso em: 15 jul. 2015.

RONDÔNIA. Exportação de café em grão sobe 166\% neste ano em Rondônia, aponta Ministério do Desenvolvimento. Idaron, 2015. Disponível em: www.RONDÔNIA.ro.gov.br/2015/11/90288/. Acesso em: 20 nov. 2015.

SANTOS, C. A fronteira do Guaporé. Porto Velho: Edufro, 2001. 
SANTOS, M. Metamorfose do espaço habitado. 3. ed. São Paulo: Hucitec, 1994.

SANTOS, M. Espaço e método. 5. ed. São Paulo: Edusp, 2014a.

SANTOS, M. A natureza do espaço: técnica e tempo. Razão e emoção. 4. ed. São Paulo: Edusp, 2014b

SANTOS, M.; SILVEIRA, M. L. O Brasil: Território e sociedade no início do século XXI. $11^{\circ}$ ed. Rio de Janeiro: Record, 2008.

SANTOS, T. R. S.; SILVA, R. G. da C. Campesinato e o café na Amazônia Ocidental: uma análise territorial dos núcleos cafeeiros no estado de Rondônia. In: Simpósio Internacional de Geografia Agrária, 7, 2015, Goiânia, Anais...Goiânia:UFG, 2015, p. 3897-3911. CD-ROM.

SILVA, R. G. da C. Espaço, sociedade e natureza em Rondônia. Revista GeoAmazônia, Belém, n. 2, v. 1, p. 144-165, jan./jun. 2014. Disponível em: www.geoamazonia.net/index.php/revista/article/view/26/pdf_25. Acesso em: 18 set. 2015.

SILVA, R. G. da C. Amazônia globalizada: da fronteira agrícola ao território do agronegócio - o exemplo de Rondônia. In: Confins, n. 23, 2015. Disponível em: http://confins.revues.org/9949?lang=pt\#tocto1n1. Acesso em: 9 nov. 2015.

SILVEIRA, M. L. Território usado: dinâmicas de especialização, dinâmicas de diversidade. Ciência Geográfica, Bauru, v. 15, n. 1, p. 4-12. jan/ dez. 2011. Disponível em: www.agbbauru.org.br/publicacoes/revista/ anoXV_1/AGB_dez2011_artigos_versao_internet/AGB_dez2011_01. pdf. Acesso em: 20 dez. 2015.

VENEZIANO, W. Cafeicultura em Rondônia: situação atual e perspectivas. Porto Velho: Embrapa, 1996. 


\section{A ESTRUTURA FUNDiÁRIA E SUAS ESPECIFICIDADES NO RURAL: APONTAMENTO PARA O PLANEJAMENTO TERRITORIAL DE RONDÔNIA}

Denes Luís Reis Pedrosa*

\section{INTRODUÇÃO}

O estado de Rondônia tem aparecido na mídia nacional como um dos cenários de violência por conta da luta pela terra. A distribuição foi iniciada na década de 1970 e ainda existem áreas com problemas de documentação envolvendo sua titularidade, o que deixa os posseiros inseguros e sem poder recorrer a financiamentos bancários e às necessidades jurídicas. Em algumas áreas existe a superposição de propriedades que gera violência e ações judiciais.

$\mathrm{Na}$ luta entre proprietários e posseiros, para fins de proteção e direito à propriedade, consta uma série de documentos que envolvem a Regularização Fundiária. O governo Federal, com o intuito de dirimir problemas no campo, cria a necessidade do georreferenciamento da propriedade como componente da Regularização Fundiária, pela lei ${ }^{\circ}$ $10.267 / 2001$, onde constam suas normas e técnicas, obrigatoriedades e funções sociais.

Por meio do georreferenciamento é possível conhecer o espaço da propriedade e, a partir daí a realidade que abarca o campo brasileiro, principalmente no tocante à segurança do detentor da titularidade. No Brasil, o Incra é o órgão responsável por garantir e assegurar a eficiência desse serviço. A regularização fundiária se torna um caminho imprescindível para o alcance do pleno desenvolvimento do nosso estado, onde está diretamente relacionada ao processo de crescimento e pode ser considerado o vetor que movimenta a economia, assim, proporcionando o aumento da produtividade, gerando riqueza para o estado.

\footnotetext{
" https://orcid.org/0000-0002-6824-2669
} 


\section{Geografias de Rondônia Território, Fronteira e Educação}

Este artigo se pauta na necessidade do conhecimento preciso e sistemático do espaço vivido, onde se destaca a importância da regulamentação da estrutura fundiária e na constituição de uma base que sirva de ferramenta para o planejamento e gestão do território. Por meio do georreferenciamento é possível conhecer o espaço rural, e a partir daí a realidade que abarca o campo brasileiro, pensando a produção e preservação do mesmo.

\section{O PRINCÍPIO DA FUNÇÃO SOCIAL DA PROPRIEDADE RURAL}

O Estatuto da Terra (Lei n. 4.504/1964), que é o código agrário brasileiro, examina em muitos artigos o problema da reforma agrária e da política fundiária, adotando o método liberal e democrático de solução da matéria, porém, salienta que regularização fundiária é um instrumento da Reforma Agrária, tanto que se difere da política agrícola, tendo seu foco no disciplinamento da posse da terra e do uso adequado da mesma. Traz em seu bojo a preocupação com a função da propriedade, as atividades a ela atinentes e a harmonização com o meio ambiente, pois, a mesma deve ser promovida sob o prisma das normas de preservação ambiental.

Ressalta-se, desde já, que a política de regularização fundiária tem caráter temporário e curativo, sendo necessário que ocorra a promoção de políticas para facilitar à população carente o acesso à moradia, para, assim, coibir um círculo vicioso de regularização.

A política de regularização fundiária representa uma ruptura paradigmática nas políticas habitacionais brasileiras. Entendemos que o legislador, ao prever esta política pública, reconheceu o direito à moradia dos habitantes dos assentamentos informais e as peculiaridades apresentadas nestas áreas.

A propriedade passou a ter grande importância sob o prisma do fator produção. Podemos observar que o direito à propriedade era absoluto, e quem possuía, achava que ninguém pudesse interferir, nem mesmo o Estado.

Podemos afirmar que, abraçando a filosofia da função social, foi trazido ao mundo do direito o conceito socioeconômico de propriedade, bem como de produção, dessa forma, sendo econômico e jurídico, para poder balizar as leis da economia, reafirmando que a propriedade da terra só desempenhará na íntegra a sua função social, quando tiver em 


\section{A estrutura fundiária e suas especificidades no rural: apontamento para o planejamento territorial de Rondônia}

seu fim, os requisitos básicos que a Constituição Federal de 1988 traz em seu art. 186:

Art. 186 - A função social é cumprida quando a propriedade atende, simultaneamente, segundo critérios e graus de exigência estabelecidos em lei, aos seguintes requisitos:

I - aproveitamento racional e adequado;

II - utilização adequada dos recursos naturais disponíveis e preservação do meio ambiente;

III - observância das disposições que regulam as relações de trabalho;

IV - exploração que favoreça o bem-estar dos proprietários e dos Trabalhadores (Brasil, 1988).

A função social da propriedade rural é atendida quando do cumprimento simultâneo com os quatro requisitos acima apresentados. A norma que rege a função social da propriedade tem o condão de dar sentido amplo ao conceito econômico, como sendo uma fonte de riqueza que se destina à produção de bens para satisfazer as necessidades sociais individuais e coletivas. De acordo com Almeida (2004), os movimentos sociais apresentam-se como um fator de existência coletiva, que contesta esta insistência nos procedimentos operativos de ação sem sujeito. É a partir deste prisma que pretendo chamar a atenção para a relevância de se abrir uma discussão ampla sobre as "terras tradicionalmente ocupadas" e sobre os processos de territorialização que lhes são correspondentes no momento atual.

De acordo com Moreira (2007, p. 63 e 65), é preciso compreender o "caráter social do espaço geográfico" enquanto transformação do meio pelos seres humanos, que se dá como trabalho social ou "ação organizada dos homens em coletividade", onde afirma que, é por meio do arranjo espacial que se reproduz o conhecimento das leis de reprodução social, onde a pesquisa tem como função se basear nesse processo, sendo um objetivo conclusivo da geografia.

Nesse diapasão, verifica-se que se legitima o conceito da função social da propriedade pela sua capacidade de produzir e gerar riqueza em consonância com os requisitos ambientais e de relações de trabalho, 


\section{Geografias de Rondônia Território, Fronteira e Educação}

\section{A CRIAÇão DE ÓRGÃos ESPECífICOS DE REGULARIZAÇÃo}

Ao longo da história muitos foram os órgãos criados com a finalidade de promover a regularização fundiária, e as revoltas surgidas foram sempre destruídas com violência pelos governos ligados aos grupos dominantes.

Com o surgimento das Ligas Camponesas e dos sindicatos rurais, o movimento dos camponeses se organiza como forma de luta legal. Pressionam para que o governo crie formas de garantir o acesso à propriedade da terra; intensificam os movimentos por meio de greves e ocupações de propriedades não utilizadas, na tentativa de ver acontecer a reforma agrária. Com isso, se agravam os problemas correlatos à questão da propriedade da terra.

Na Amazônia, os direitos humanos, durante décadas, estive-
ram subordinados aos direitos do capital e muitas situações
acabaram se cristalizando. Durante mais de vinte anos esses
problemas acumularam-se sem solução, a não ser em casos
pontuais e após conflito seguido de morte. Nesse período, a
terra pública transformou-se, por meios legais, fraude ou grila-
gem, em terra privada (Loureiro; Aragão Pinto, 2005).

No ano de 1963 é instituído o Estatuto do Trabalhador Rural, que passa a dar garantias às famílias do campo, sendo: salário-mínimo, férias, repouso remunerados, aviso prévio e indenização em caso de demissão.

Também, no mesmo ano, surge a Superintendência da Reforma Agrária (Supra), cujo objetivo era fazer a reforma agrária e reconhecer aqueles que detinham a posse. Porém, com o golpe militar de 1964, inicia um período de autoritarismo, onde a população do campo passa a ser reprimida.

Devido às grandes pressões que esses órgãos sofreram por parte do setor latifundiário, surge em 1970, o Instituto Nacional de Colonização e Reforma Agrária (Incra). Os levantamentos iniciados pelo IBRA e, posteriormente, nos anos de 1967, 1972 e 1976, pelo Incra, demonstraram um domínio completo dos latifúndios improdutivos no território brasileiro, impedindo milhões de trabalhadores de terem acesso à terra e à produção. Os minifúndios, mesmo em maior número, ocupavam áreas pequenas e respondiam pelo grande volume da produção brasileira 


\section{A estrutura fundiária e suas especificidades no rural: apontamento para o planejamento territorial de Rondônia}

de alimentos. O resultado desse estudo acabou sendo abafado devido à relação do governo militar com a elite rural.

O cenário nacional torna-se delicado. De um lado, há movimentos que pleiteiam a aplicação do Plano de Reforma Agrária, considerado moderado e contraditório, e os que querem a reforma imediatamente, por meio da ocupação de terras improdutivas. Do outro lado, os grandes latifundiários radicalizam o processo e resistem à implantação de mudanças.

De acordo com Loureiro e Aragão Pinto (2005), se a concentração de renda provocada pela política de incentivos, era por si só danosa para a região (já que beneficiava apenas os grandes grupos econômicos nacionais e estrangeiros), o dano maior, entretanto, estava ligado à questão da terra. Nos anos de 1970 e 1980, a terra pública, habitada secularmente por colonos, ribeirinhos, índios, caboclos e comunidades tradicionais em geral, foi sendo colocada à venda em lotes de grandes dimensões para os novos investidores que as adquiriam diretamente dos órgãos fundiários do governo ou de particulares (que, em grande parte, revendiam a terra pública como se ela fosse própria).

Em ambos os casos, era frequente que as terras adquiridas fossem demarcadas pelos novos proprietários numa extensão muito maior do que a dos lotes que originalmente haviam adquirido.

Entretanto, devido às dimensões do território nacional e regional, no caso do estado de Rondônia, as ações a serem desenvolvidas não podem ocorrer ao mesmo tempo e em todas as partes. É preciso observar as prioridades, levando-se em conta as necessidades mais urgentes de cada região ou área específica. O que tem que ser evitado é a implantação de programas em áreas isoladas, em detrimento de outras, pois, favorece a formação de focos de resistência contra as reformas.

As etapas que devem compor um processo de reforma agrária não precisam seguir uma sequência obrigatória, podendo variar ou mesmo ser eliminadas, dependendo do desenvolvimento específico de cada área.

\section{DA NECESSIDADE DA REGULARIZAÇÃO FUNDIÁRIA EM RONDÔNIA}

As circunstâncias especiais que revestem a situação fundiária em Rondônia, atualmente, dão conta de uma realidade frente a qual o governo vem sendo chamado a manifestar e buscar alternativas. A regularização fundiária é uma política pública que visa regularizar a proprie- 


\section{Geografias de Rondônia Território, Fronteira e Educação}

dade e a posse da terra, portanto, é algo imprescindível para o desenvolvimento do estado.

Nesse contexto é salutar a importância da regularização no tocante à ampliação da segurança jurídica, pois, este reconhece o seu direito sobre a terra, o acesso às linhas de crédito, fomento a desconcentração fundiária e a democratização do acesso à terra. A regularização fundiária como ação complementar é a de maior alcance socioeconômico, porque gera emprego e renda cumulada com justiça social, por meio de assentamento de trabalhadores rurais, influenciando sobremaneira na economia, pela produção de alimentos e matérias-primas, seja em Projetos de assentamento ou na regularização de ocupação. Neste contexto, o Poder Público tem por imperativa missão promover a obtenção dos recursos fundiários em áreas desapropriadas ou em terras públicas destinando-as, nos termos da Lei, observando a vocação e uso da oferta ambiental.

O Incra, na condição de representante da União, buscando assegurar e estimular os meios necessários à efetiva e ordenada ocupação da vasta região, então denominação de "vazio amazônico", promoveu na década de 1970 e 1980, a alienação de milhares de hectares de terras públicas federais, mediante regular e correto procedimento licitatório. A ação fundiária em Rondônia teve início no final dos anos 60 e fora intensificada a partir da década de 70 , quando acionou um significativo processo de organização territorial rural, por meio do qual foram criados 146 projetos, proporcionando o assentamento de milhares de famílias de trabalhadores rurais.

Paralelamente, com o procedimento discriminatório, arrecadaram-se extensas glebas de terras ao domínio da União, com a expedição de título de propriedade, licença e autorização de ocupação, carta de sentença, certificado de remição de foro, título de domínio, ratificatório, carta de anuência, contrato de promessa de compra e venda, contrato de concessão de domínio de terras públicas, contrato de alienação de terras públicas, e ainda 2.725.000 hectares de terras, cujo domínio de particular foi reconhecido pelo Incra/RO em função de títulos e outros documentos expedidos no início do Século XX, pelos governos dos estados do Amazonas e Mato Grosso, incluindo o Território Federal de Rondônia. Ampliando, desta forma, a expansão da fronteira agrícola nacional, permitindo, como consequência, a ocupação ordenada do vazio demográfico da Região Norte do país e da divisa do Brasil com a Bolívia. 


\section{A estrutura fundiária e suas especificidades no rural: apontamento para o planejamento territorial de Rondônia}

A aquisição de áreas rurais, sem preferência, ocorria através de edital de licitação, tendo como objetivo receber propostas de obtenção de lotes da União através de alienação às pessoas físicas ou jurídicas. Dentre vários requisitos, era fixada a utilização dos imóveis, objeto do certame licitatório, ou seja, para exploração agrícola, pecuária ou florestal, com a concessão ao licitante vencedor de Contrato de Alienação de Terras Públicas - CATP.

Consagrado vencedor, o licitante, na forma estipulada no edital, dispunha do prazo de 60 (sessenta) dias para efetuar a quitação do valor do imóvel, condição obrigatória para recebimento do Contrato de Alienação de Terras Públicas - CATP, significando dizer que a compra foi realizada à vista. A partir daí o concessionário seria obrigado a cumprir prazos, a serem contados da data de outorga dos referidos instrumentos de titulação:

- Ocupação da área dentro de 1 (um) ano;

- Medição e demarcação do lote no prazo de 2 (dois) anos;

- Implantação do Projeto de aproveitamento agropecuário vinculado ao lote no período de 5 (cinco) anos.

De acordo com a cláusula sexta do CATP, o descumprimento pelo adquirente, de qualquer das obrigações contidas nos termos contratuais, importa em sua resolução, de pleno direito, independentemente de qualquer procedimento ou medida judicial, importando em perda e reversão do lote ao patrimônio público; indenizadas as benfeitorias necessárias, efetuada e restituída a importância paga pelo imóvel, ressalvando os créditos hipotecários.

A priori, é bom ter presente a natureza jurídica do contrato (CATP), com o alcance que a legislação confere ao mesmo, notadamente o Decreto n. 2.375 , de 24 de novembro de 1987 , seu artigo $7^{\circ}$, que habilita a tais instrumentos o valor da eficácia de escritura pública, obviamente, do ponto de vista doutrinário, tal espécie, impôs nova regra à Administração no que diz de prerrogativas na alteração e rescisão unilateral de tal contrato.

Art. $7^{\circ}$ - Os termos, contratos e títulos, expedidos pela União, pelos Estados, Municípios, Territórios ou entes de sua administração descentralizada, que se destinem a instrumentalizar 


\section{Geografias de Rondônia Território, Fronteira e Educação}

a alienação, concessão, arrecadação ou o reconhecimento de domínio sobre terras públicas rurais, terão, para todos os efeitos, valor e eficácia de escritura pública (Brasil, 1987).

Com a expansão do desenvolvimento nacional, o então território passou a ser ocupado intensamente por agricultores excedentes do Sul e Centro-Oeste do Brasil e grupos de posseiros, dada, especialmente, a abertura de rodovias, somada à qualidade e ao baixo preço do solo rondoniense.

\section{A extinção das condições resolutivas nos Títulos de Propriedade}

Existem vozes que ecoam no sentido da não retirada das cláusulas resolutivas dos títulos de propriedade expedidos pelos órgãos de regularização fundiária, mas, é sabido que, a partir da outorga de um título que possua condições resolutivas e cláusula de inalienabilidade, o posseiro passa a ser o dono desse bem.

A propriedade, enquanto bem, se configura como relação entre pessoa e coisa. Portanto, as coisas, ou bens, devem ser instrumento a serviço dos homens para a satisfação de suas necessidades (Oliveira, 2001, p. 11).

Desta forma, pode-se concluir que, uma vez concedido o título de domínio, o posseiro passa a ser proprietário do imóvel rural em sua totalidade, passando a incidir, a partir daí a autonomia privada na administração do bem particular. Caberá ao Estado auxiliá-lo nesta administração, mas, não poderá, de forma alguma, impor o modo de gerenciamento do patrimônio alheio. Com isso, teremos a ampliação da segurança jurídica, por permitir uma destinação plena, condicionada apenas na quitação do título ora expedido.

Não é demais lembrar que nos anos de 1970 e 1980 foi marcado pela necessidade de se incrementar nas regiões menos desenvolvidas do país uma atividade agropecuária caracterizada pelo emprego da moderna tecnologia de uso e exploração do solo. Essa foi a filosofia que orientou, no tocante ao campo fundiário, o traçado nas diretrizes e prioridades estabelecidas cujo propósito foi, sem dúvida, o de abrir à iniciativa privada, que nas últimas décadas vieram demonstrando seu potencial e capacidade em desenvolver o campo de Rondônia, possibili- 


\section{A estrutura fundiária e suas especificidades no rural: apontamento para o planejamento territorial de Rondônia}

tando projetar também, no meio rural, a implantação de projetos agropecuários que souberam apresentar as melhores técnicas de exploração que atendesse aos princípios preconizados pelo Estatuto da Terra, Lei $\mathrm{n}$. 4.504 de 30 de novembro de 1964, destinados à implantação de médias e grandes empresas rurais, a fim de atender às necessidades de consumo, desenvolvimento econômico, por outro lado, amplia uma problemática de situações adversas, provocação uma desigualdade social, tanto na questão social, econômica e cultural, como na realidade in loco, há respeito do tamanho real das propriedades, provocando conflitos agrários.

É necessário se atentar para o fato de que o meio rural em Rondônia vem se processando em escala bastante dinâmica e célere, e a terra cada vez mais valorizada, fruto de uma regularização que tem causado seu efeito do ponto de vista de valorização desse bem.

Ao longo dos últimos 40 anos, em função de inúmeros fatores internos e externos ao órgão responsável (Incra), durante o processo de colonização e assentamento das famílias agricultoras, algumas inconsistências e situações problemáticas foram se acumulando e gerando um passivo de documentação e regularização de milhares de parcelas rurais.

Esse passivo de regularização e titulação das famílias que aqui residem está impossibilitando que as mesmas acessem diversas modalidades de crédito e outras políticas públicas. A dificuldade de acesso aos projetos de incentivo à produção para as famílias, resulta em redução da condição produtiva e consequentemente menor capacidade de obtenção de renda. Nesse sentido, a falta de regularização fundiária é sinônimo de manutenção da pobreza no campo rondoniense.

\section{Projetos de assentamentos da Reforma Agrária}

Os inúmeros projetos de assentamentos criados no estado de Rondônia oportunizaram a milhares de trabalhadores rurais sem terras a possibilidade de produzirem o próprio alimento, bem como comercializarem o seu excedente.

Em seu histórico, o Incra foi um importante órgão na colonização e gestão sobre terras públicas federais, porém, acumulou grande passivo de problemas diferenciados. Desde o período da colonização de Rondônia, era grande a procura de famílias que buscavam acesso à terra nos escritórios do órgão, além dos projetos PIC e PAD. Assim, na década de 1980, como forma de identificar a demanda e planejar alternativas de atendimento aos migrantes, o Incra abriu inscrições para os interessados 


\section{Geografias de Rondônia Território, Fronteira e Educação}

em ter acesso à terra. $\mathrm{O}$ resultado foi a inscrição de aproximadamente 16 mil famílias.

De acordo com o Incra, entre os anos de 1970 e 2017 foram criados 219 projetos de assentamentos, com uma divisão de 64.959 parcelas rurais, conforme demonstrado na Tabela 1 abaixo.

Tabela 1 - Rondônia - Número de projetos, total de parcelas rurais (1970-2017).

\begin{tabular}{|c|c|c|}
\hline Datas da criação & $\begin{array}{c}\text { Número de projetos } \\
\text { criados }\end{array}$ & Número de parcelas rurais \\
\hline $1970-1979$ & 7 & 23.721 \\
\hline $1980-1989$ & 18 & 12.954 \\
\hline $1990-1999$ & 66 & 14.826 \\
\hline $2000-2009$ & 81 & 11.939 \\
\hline $2010-2012$ & 29 & 994 \\
\hline $2013-2017$ & 18 & 525 \\
\hline Total & 219 & 64.959 \\
\hline
\end{tabular}

Fonte: Incra, 2021. Organização: Pedrosa, 2017

Dos números apresentados acima, há em Rondônia um passivo de aproximadamente $50 \%$ de parcelas nos projetos de assentamentos sem regularização, que estão divididas em algumas áreas a exemplo das terras públicas não destinas à ocupação.

A problemática fundiária do estado envolve não somente as áreas de projetos de assentamentos, mas também, as terras públicas da União não destinadas à ocupação, onde, aproximadamente, há 20 anos estava relegada a ação de destinação das áreas, chegando esse passivo a aproximadamente 16 mil imóveis sem documentação, incluindo a pequena, média e grande propriedade rural, que tem como tempo de posse, 15 a 20 anos, e com processo formalizado, requerendo o direito de propriedade. 


\section{A estrutura fundiária e suas especificidades no rural: apontamento para o planejamento territorial de Rondônia}

\section{Georreferenciamento Como Ferramenta para o Planejamento e Gestão do Território}

Quando nos aprofundamos na história a respeito do planejamento e gestão territorial, faz-se necessário compreender que algumas regiões desenvolvidas, atualmente, passaram por algum processo de gestão e ordenamento do espaço, sendo que o reflexo de tais mudanças tem sido a determinação de situações de alterações fundiárias semelhantes às que possuem na área proposta nesse trabalho, qual seja: a Gleba Corumbiara, localizada no município de Vilhena, no estado de Rondônia (Figura 2).

Ao entender o quadro atual a respeito do planejamento e da gestão do território na área estudada, fica fácil interpretar que possui, de fato, algumas atitudes por parte de gestores que não facilitam e provoca uma desigualdade fundiária, como podemos verificar na (fig.04), onde os dados do sistema de gerenciamento de lote (Siglo) foram usados para a atual demarcação, apresentando uma desigualdade no tamanho das propriedades, sendo algumas delas, acima de 2.000 hectares, assim proporcionando conflitos e mortes por motivos de não possuírem a documentação necessária e, especialmente, uma demarcação confiável e juridicamente reconhecida, o que necessita de lutas e reivindicações por uma demarcação necessária e igualitária de interesse público.

A partir do que foi mencionado, verificamos, que Rondônia tem aparecido na mídia nacional como um dos cenários de violência por conta da "luta pela terra". A distribuição de terras no estado foi iniciada em 1970, sendo que ainda existem terras com problemas de documentação envolvendo a titularidade das áreas e que deixam seus posseiros inseguros e sem poder recorrer a financiamentos bancários.

Diante disso, o Governo Federal, com o intuito de dirimir problemas no campo, se cria a necessidade da demarcação exata de uma propriedade como componente da Regularização Fundiária, por meio da Lei n. 10.267/2001, criando suas normas e técnicas, obrigatoriedades e funções, possibilitando a criação de dados de uma precisão com uma alta definição, facilitando a organização mais precisa do espaço, e contribuindo para outras temáticas, com exemplo, uma análise temporal da propriedade, o que podemos verificar na (Figura 1).

Sendo assim, por meio dessa técnica é possível conhecer o espaço da propriedade e, a partir daí a realidade que abarca, principalmente no tocante à segurança do detentor da titularidade, sendo que no Brasil o 


\section{Geografias de Rondônia Território, Fronteira e Educação}

Incra é o órgão responsável por garantir e assegurar a eficiência desse serviço (BRASIL, 2001). Diante da grande extensão territorial da Gleba mencionada neste artigo, foi escolhido o município de Vilhena para ser a área de estudo, o qual situa-se entre as coordenadas $12^{\circ} 44^{\prime} 26^{\prime \prime}$ latitude sul e $60^{\circ} 08^{\prime} 44^{\prime}$ ' longitude oeste, tendo como principal via de acesso a BR-364.

Contudo, ao analisar a área de estudo nesse trabalho, uma parte da Gleba Corumbiara, localizada no município de Vilhena, serviu como uma ferramenta para projetos que tinham como propósito a ocupação por meio do processo de colonização, como em toda a região da Amazônia, sendo criadas unidades variadas de proporção de plantio para a produção. Eles, então, formavam a mão de obra para os grandes latifundiários que se implantavam na época, formando os projetos de colonização que não tiveram sucesso na questão do fator de regularização fundiária, pois a grilagem e os conflitos se mantiveram em todo país, tendo como atores: camponeses, grileiros e grandes fazendeiros para a disputa de terras, considerando que os mesmos possuem grandes empresas do agronegócio com o objetivo de ocupar grandes áreas, beneficiando-se através de formas inconstitucionais e criminais, como será detalhado nesse trabalho em uma parte da Gleba Corumbiara, localizada no município de Vilhena.

Essa desigualdade do ordenamento territorial é vista na (Figuras 3 e 4), onde se encontra lotes georreferenciados pelo estado e por empresas particulares com aval de normas técnicas estabelecida pelo órgão competente (Incra), além de facilitar para o Cadastro Ambiental Rural (CAR), onde o mesmo virou uma ferramenta para crimes contra Áreas Especiais em todo País. Em relação às medições, a estrutura fundiária do estado de Rondônia e seu ordenamento territorial são de responsabilidade do Incra, seguindo as normas de medidas pela Lei n. 8.629/93, que, no seu art. $4^{\circ}$, II, estabelece uma classificação em relação a sua extensão em três níveis: Pequena Propriedade - entre 1 (um) e 4 (quatro) módulos fiscais; Média Propriedade - superior a 4 (quatro) e até 15 (quinze) módulos fiscais; e, Grande Propriedade - superior a 15 (quinze) módulos fiscais. Isso pode ser visualizado nos dados do sistema de gerenciamento de lotes, que tem dados a partir dos anos 1970. 
A estrutura fundiária e suas especificidades no rural:

apontamento para o planejamento territorial de Rondônia

Figura 1 - Uso de dados Georreferenciados (2021).

USO DE DADOS GEORREFERENCIADOS PARA ANÁLISE AMBIENTAL

Sistema de coordenade

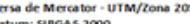

Imagem Landsat TM 5 - 10/06/2006 - Orbita/Ponto 311/082

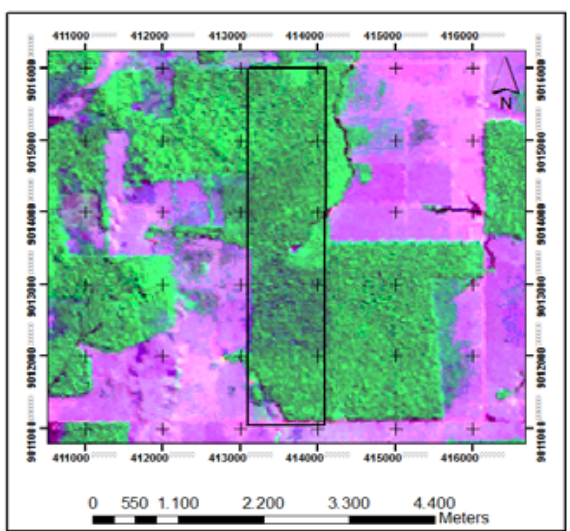

Imagem Resourcesat - 10/08/2015 - Órbita/Ponto 311/082

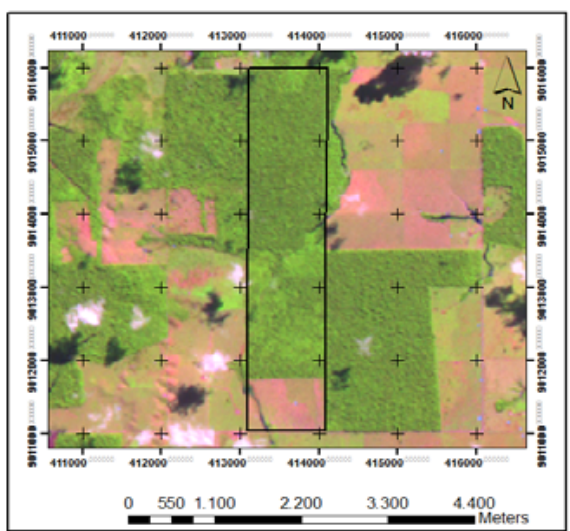


Geografias de Rondônia Território, Fronteira e Educação

Figura 2-Área de localização da Gleba Corumbiara, Vilhena-RO. (2021).

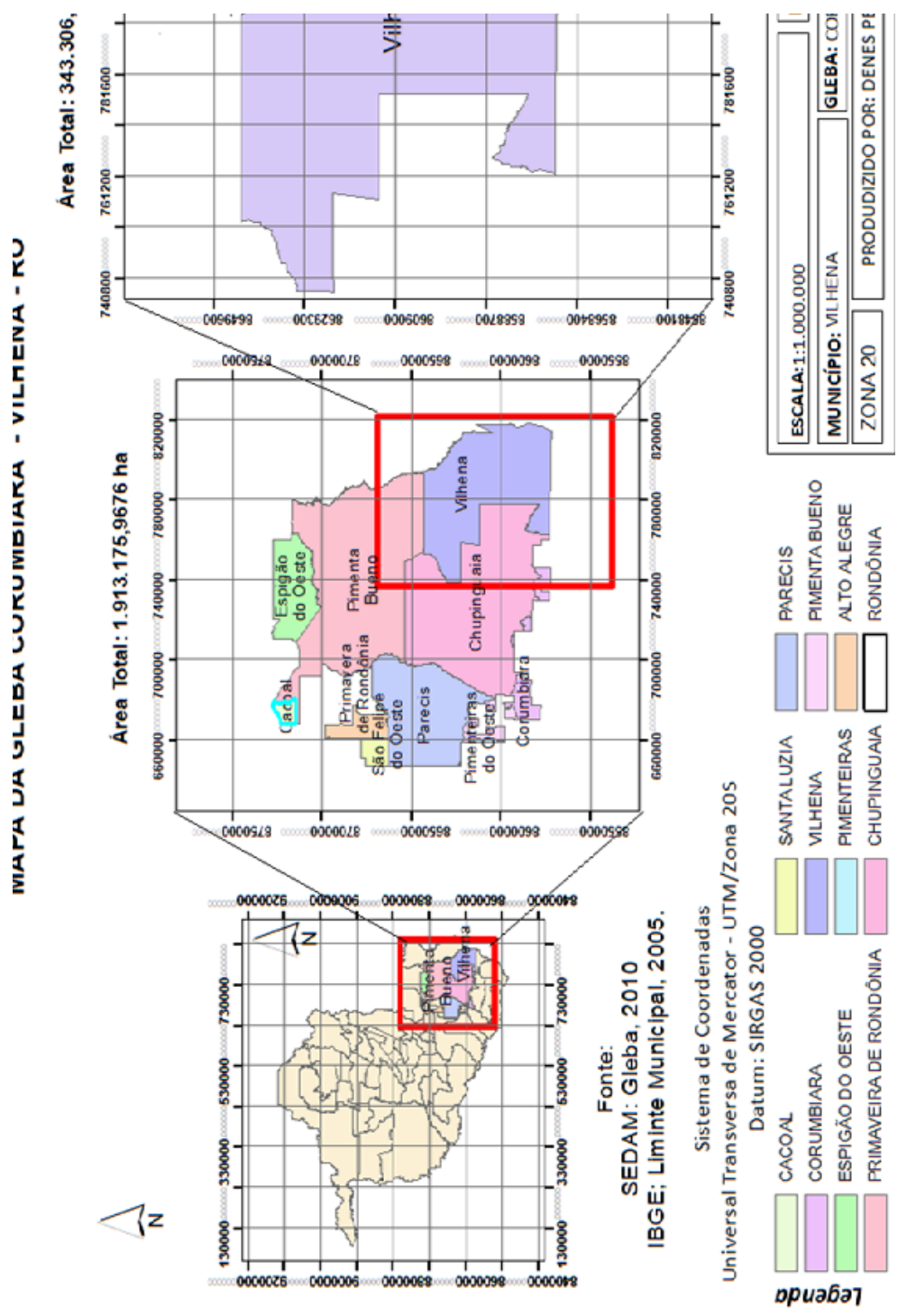


A estrutura fundiária e suas especificidades no rural: apontamento para o planejamento territorial de Rondônia

Figura 3 - Parcelas Georreferenciadas - Particular - Corumbiara Vilhena-RO. (2021).

ANALISE DE OCUPACÃO EM PARCELAS DA REGULARIZACAO FUNDIARA - PARTICULAR - SIGEF

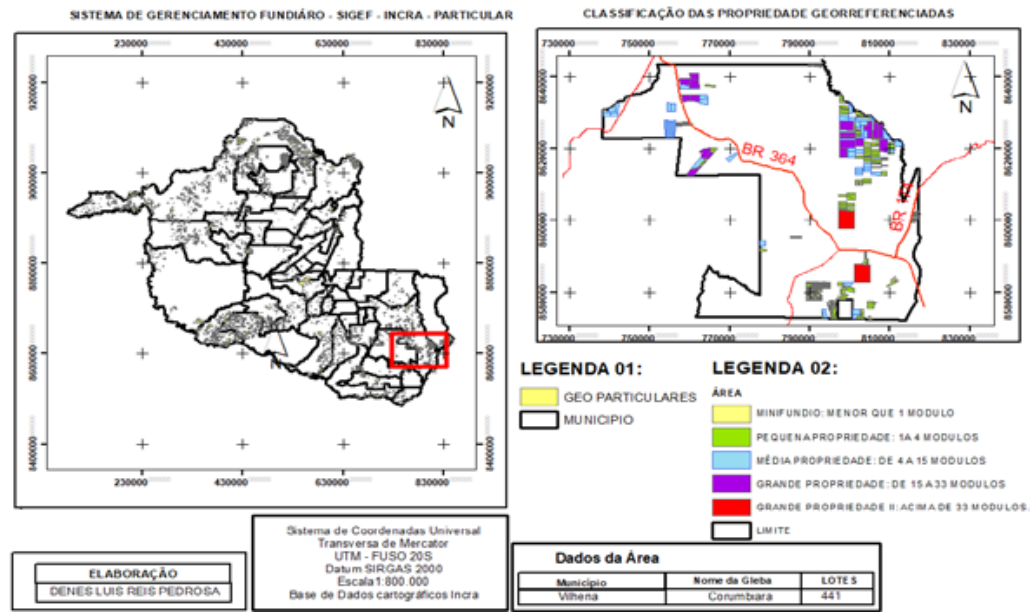


Geografias de Rondônia Território, Fronteira e Educação

Figura 4 - Classificação das Propriedade por Módulos - Vilhena - RO. (2021).

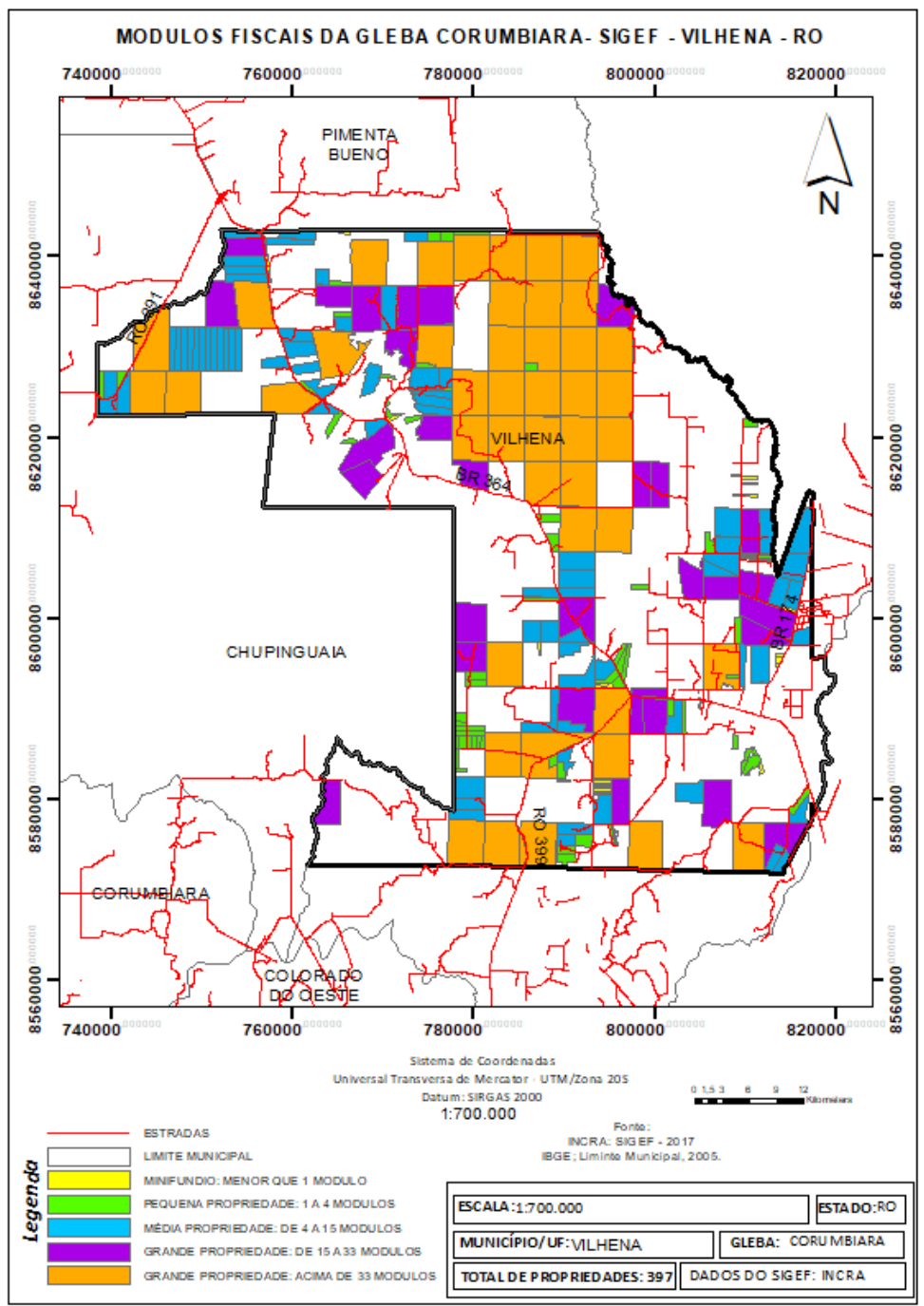




\section{A estrutura fundiária e suas especificidades no rural: apontamento para o planejamento territorial de Rondônia}

A maioria dos migrantes que ocupou a Gleba Corumbiara, no município de Vilhena, se deslocaram das regiões do Sul e Sudeste do País, com suas estações alternadas. Chegando na região, sentiram outra situação referente aos regimes de clima e temperatura, o que motivou os ocupantes a criarem uma forma de lidar com a produção: muitos deles não obtiveram êxito, procurando uma nova forma de viver e buscando outras formas para a distribuição das terras. Assim, a especulação tomou conta e contribuiu para a atual situação latifundiária da região, uma vez que, atualmente, a área vem se destacando por intensos conflitos agrários motivados pela disputa por terras, por agentes territoriais, entre eles: indígenas, posseiros, assentados da reforma agrária, pecuaristas, produtores de grãos e grileiros.

Diante dos fatos, em uma visão de todo estado, muitos trabalhadores obtiveram sucesso na ocupação de uma propriedade através de projetos e programas sociais para a regularização fundiária. No entanto, o Governo, em seu processo temporal, não teve o compromisso de adquirir para todos os trabalhadores, possibilitando, assim, o aumento da desigualdade e da radicalização da pobreza e do desemprego para os que escolheram ficar, em especial na Gleba Corumbiara, em Vilhena, onde, até hoje, encontram-se com bastante dificuldades, principalmente pela falta de gestão e de distribuição de terra digna e coerente.

\section{CONSIDERAÇÕES FINAIS}

Diante do exposto, a necessidade de um ordenamento territorial adequado e igualitário na área de estudo, bem como a intersecção com outras políticas públicas visam buscar soluções ao combate de conflitos agrários na região, o que possibilita compreender que a sociedade está condicionada às ações institucionais. Desta forma, as técnicas e as normas do georreferenciamento têm como objetivo fortalecer a organização e o ordenamento espacial de uma determinada área e, neste contexto, buscamos delimitar os nossos objetivos referentes à área de estudo por estar em uma terra historicamente marcada por conflitos agrários e questões de demarcações em seu processo temporal de regularização.

É importante também registrar que apesar dos problemas de sobreposição que atinge o estado de Rondônia, é de grande importância, compreender como os gestores públicos, profissionais ligados ao georreferenciamento de imóveis rurais e de cartórios de registro, atuam com as políticas de regularização da área de situação, fica evidente a premente 


\section{Geografias de Rondônia Território, Fronteira e Educação}

necessidade em garantir o processo de regularização em todo o estado de Rondônia, através de Termo Cooperação Técnica, Convênios ou outros instrumentos similares, dos órgãos responsáveis pela matéria com órgãos e entidades parceiras, tais como: Estado, prefeituras, sindicatos, dentre outros, pois só assim teremos o passivo fundiário resolvido, e consequentemente a segurança jurídica, o desenvolvimento através do acesso às linhas de crédito, o fortalecimento da agricultura e finalmente a pacificação do meio rural.

\section{REFERÊNCIAS}

ALMEIDA, A. W. B. Terras tradicionais ocupadas por processos de territorialização e movimento. Revista brasileira de estudos urbanos e regionais, v. 6, n. 1, maio de 2004. Disponível em: http://rbeur.anpur.org.br/ rbeur/article/view/102/86. Acesso em: 19 maio 2018.

BRASIL. Lei 4.504, de 30 de novembro de 1964. Dispõe sobre o Estatuto da Terra, e dá outras providências. Disponível em: www.planalto.gov.br/ ccivil_03/leis/14504.htm. Acesso em: 8 out. 2017.

BRASIL. Constituição Federal de 1988, Capítulo III da política agrícola e fundiária e da reforma agrária. Disponível em: https://brasil.mylex.net/ legislacao/constituicao-federal-cf-art186_10531.html

BRASIL. Lei n. 11.952 de 25 de junho de 2009. Dispõe sobre a regularização fundiária das ocupações incidentes em terras situadas em áreas da União, no âmbito da Amazônia Legal; altera as Leis nos 8.666, de 21 de junho de 1993, e 6.015, de 31 de dezembro de 1973; e dá outras providências. Disponível em: www.planalto.gov.br/ccivil_03/_ato20072010/2009/lei/l11952.htm

BRASIL. Decreto n. 2.375, de 24 de novembro de 1987, Artigo $7^{\circ}$. Dispõe sobre terras públicas e dá outras providências. Disponível em: www.planalto.gov.br/ccivil_03/decreto-lei/Del2375.htm.

LOUREIRO, V. R.; ARAGÃO PINTO, J. N. A questão fundiária na Amazônia. Estudos avançados, São Paulo, v. 19, n. 54, maio/ago. 2005. Disponível em: www.scielo.br/scielo.php?script=sci_arttext\&pi$\mathrm{d}=$ S0103-40142005000200005. Acesso em: 19 maio 2018.

MOREIRA, R. Pensar e ser em Geografia. Ensaios de história, epistemologia e ontologia do espaço geográfico. São Paulo: Contexto, 2007.

OLIVEIRA, A. V. de. Função Social da Propriedade Rural. Revista Consulex, Ano V, n. 97, jan., 2001, p. 11-17. 
A estrutura fundiária e suas especificidades no rural:

apontamento para o planejamento territorial de Rondônia

RIBEIRO, A. F. A; SILVA, R. G.C; SANTOS, J. L. Política de regularização fundiária em Rondônia: limitações do Programa Terra Legal e expectativas socioterritoriais. Confins (Paris), v. 29, p. 1-19, 2016. Disponível em: http://confins.revues.org/11541. 


\section{PARTE 3}

\section{GEOGRAFIA, EDUCAÇÃO E TERRITORIALIDADES}




\title{
GEOGRAFIA, LIVRO DIDÁTICO E EDUCAÇÃO: PROBLEMATIZAÇÕES DA TEMÁTICA AGRÁRIA NO ENSINO FUNDAMENTAL ${ }^{1}$
}

\author{
Ricardo Gilson Costa Silva* \\ Mirian Pereira Suave** \\ Josélia Gomes Neves****
}

\section{INTRODUÇÃO}

Nas mais diversas escolas públicas e privadas do Brasil o livro didático é um recurso metodológico, um guia curricular e, às vezes, a principal e única "ferramenta" sistematizada do conhecimento científico e social à disposição dos professores da educação básica. Para muitos estudantes o livro é a fonte principal do conhecimento analisado em sala de aula e de leitura do mundo.

Desse modo, o ensino e aprendizagem convergem para o livro didático, o que nos leva a advertir da impossibilidade deste recurso alcançar temas e abordagens necessárias a todas as fontes e temáticas que envolvem as disciplinas na educação básica. Há lacunas de diversas ordens com epistemologias e metodologias que guiam a construção textual do livro, qualificando e delimitando o ensino. Assim, em sua operacionalização, é preciso uma aproximação entre escola, currículo, conteúdos e professores, no sentido de trazer à realidade do estudante os temas escritos para que eles possam perceber, aprender e relacionar

\footnotetext{
${ }^{1}$ Publicado em: COSTA SILVA, R. G; SUAVE, M. P.; NEVES, J. G. Geografia, livro didático e educação: problematizações da temática agrária no Ensino Fundamental. Revista Cerrados, [S. 1.], v. 19, n. 2, p. 20-51, 2021.

" https://orcid.org/0000-0002-3348-9629

** https://orcid.org/0000-0002-2243-0429

*** https://orcid.org/0000-0003-2318-5397
} 


\section{Geografias de Rondônia Território, Fronteira e Educação}

o mundo do livro com o mundo vivido nos lugares. A escala geográfica dos conteúdos e da aprendizagem se coloca como condição importante na construção do conhecimento e de mediação de temas/conteúdos para com o vivido espacial dos estudantes, seja no campo, na floresta, na cidade e nos diversos espaços geográficos habitados pela sociedade.

No Brasil, um país com graves assimetrias socioeconômicas e regionais, a questão agrária e as formas de trabalho e convívio dos grupos sociais com a natureza reúnem um conjunto temático a ser analisado em sala de aula, sobretudo, em função da diversidade social, cultural e territorial. Desse modo, se a expansão das fronteiras agrícolas no país fez emergir vários fenômenos, como a migração campo-cidade e a produção de commodities para a economia mundial, no outro polo da situação, a expansão do capital significa invasão dos territórios tradicionais do campesinato e das comunidades rurais. Sabe-se que os conflitos agrários e territoriais se intensificaram com a ação de grileiros e do agronegócio que desloca a fronteira para os assentamentos rurais, Unidades de Conservação e Territórios Culturais, de modo que, parte dos biomas anualmente se transforma em pastagens e área de soja. Os povos indígenas e as comunidades tradicionais têm seus direitos violados e, nesta direção, sofrem com as drásticas alterações que se impõem aos seus modos de vida.

Diante desse contexto, a proposta do artigo é analisar como a escola pública aborda o tema agrário no contexto da geografia escolar e quais conhecimentos os estudantes possuem referentes às temáticas que se considerou relevante na pesquisa, a saber: trabalho e produção de alimentos; modo de vida da população indígena; Movimento dos Trabalhadores Rurais Sem Terra e mulheres trabalhadoras rurais. A abordagem destes temas se fez na perspectiva da educação geográfica crítica, que possibilita ao estudante se perceber como participante do espaço onde os fenômenos, ocorrem, pois, são resultados da vida e do trabalho de homens e mulheres em processo histórico, no sentido de instigá-los a pensar como ocorreu a formação territorial do lugar onde vivem, considerando que eles não são neutros, sem vida, sem cultura e sem história (Callai, 2003).

Ao abordar as temáticas agrárias em sala de aula, fez-se necessário analisar como esses conteúdos vêm sendo retratados nos documentos curriculares que orientam o processo de ensino aprendizagem dos estudantes, principalmente o livro didático. Em seus aspectos metodológicos, o estudo se caracteriza como uma pesquisa qualitativa, focada na compreensão dos processos (Gerhardt; Silveira, 2009). Desse modo, 


\section{Geografia, livro didático e educação: problematizações da temática agrária no ensino fundamental}

as fontes dos dados foram obtidas por meio de análise documental, com foco no livro didático e no planejamento anual do professor. Também se utilizou um questionário respondido por 64 dos estudantes do $6^{\circ}$ ano da Escola Estadual de Ensino Fundamental e Médio Juscelino Kubitschek, localizada no município de Santa Luzia D’Oeste (estado de Rondônia), cuja finalidade foi identificar as percepções de ensino e aprendizagem que os alunos apresentaram acerca dos conteúdos escolhidos no âmbito da geografia agrária.

Tratou-se de compreender a percepção de aprendizagem dos estudantes, suas referências de conhecimento, por meio da verificação dos conteúdos agrários no planejamento anual do professor. A pesquisa nos direcionou a verificar como as temáticas agrárias são abordadas no livro didático, ao examinar que o planejamento do professor está correlacionado com os conteúdos veiculados no livro didático Expedição Geográfica do $6^{\circ}$ ano, aprovado pelo Plano Nacional do Livro Didático (PNLD) para o ano de 2015.

De modo geral, o texto está estruturado nas seguintes seções: O contexto agrário no livro didático de geografia: escalas geográficas e abordagens dos conteúdos, em que se problematiza a questão das abordagens temáticas e sua escala geográfica da aprendizagem que aproxima o texto do contexto espacial do estudante. Em seguida, na seção Temáticas agrárias nos livros didáticos: uma crítica aos conteúdos escolares, a partir de temas selecionados - trabalho e produção de alimentos, modo de vida da população indígena, Movimento dos Trabalhadores Rurais Sem Terra e mulheres trabalhadoras rurais - do livro didático Expedição Geográfica do $6^{\circ}$ ano, analisa-se e problematiza-se a abordagem e as lacunas sociais que poderiam constar no livro, ainda que textualmente resumidas, no sentido de ampliar os entendimentos dos estudantes referentes às diferenças e desigualdades no campo brasileiro. Para encaminhamento final, elenca-se algumas questões do ensino e da aprendizagem da disciplina geografia.

O CONTEXTO AGRÁRIO NO LIVRO DIDÁTICO DE GEOGRAFIA: ESCALAS GEOGRÁFICAS E ABORDAGENS DOS CONTEÚDOS

A educação, na perspectiva geográfica, representa uma possibilidade de construção e ampliação das aprendizagens no ambiente escolar. Para além de uma visão que privilegie de forma unilateral o ensino, o processo de aprendizagem pode ser repensado a partir do ponto de vista 


\section{Geografias de Rondônia Território, Fronteira e Educação}

de quem aprende, ou seja, dialogando com o estudante enquanto sujeito pensante que vive e vivencia o lugar, seu espaço local.

Entende-se que um ponto de partida significativo na geografia escolar é a categoria lugar, tratando-se de uma situação geográfica que pode ser articulada aos saberes dos estudantes, ancorados em suas experiências de vida. Um conjunto de perguntas pode orientar a pauta curricular que objetiva o seu entendimento acerca da formação socioespacial em que mora: como era este lugar há 10 anos? E na atualidade, quais são os novos elementos? O que determinou tais alterações?

Assim, os seres humanos em sociedade produzem sua história e as materializam no espaço geográfico, que também é construído nas práticas sociais. As informações referentes aos lugares são fundamentais para analisar como foram construídas, tanto suas bases físicas, quanto históricas, bem como, compreender os sujeitos/grupos sociais que participam dessa construção. Assim, quando se observa uma paisagem, ela revela aspectos materiais e, principalmente, os elementos imateriais que possibilitam ao indivíduo compreender as transformações ocorridas no espaço geográfico e, ainda, questionar por que isso se materializou assim e não de outra forma (Callai, 2013). Este conjunto de questões se aproxima das premissas da educação crítica, na medida em que leva em conta que: “[...] é a força criadora do aprender de que fazem parte a comparação, a repetição, a constatação, a dúvida rebelde, a curiosidade não facilmente satisfeita, que supera os efeitos negativos do falso ensinar. [...]" (Freire, 2002, p. 13).

Deste modo, para que o estudo do espaço ocorra em uma escala geográfica significativa é necessário delimitá-lo através da identificação dos níveis de extensão territorial, especificando os elementos do local, regional, nacional e global (Callai, 2009). Significa afirmar que o entendimento da categoria lugar, enquanto espaço perceptível vivido, de mediação sujeito/mundo, pode ser discutido com base nas vivências dos estudantes em dialogia com os saberes geográficos (Pontuschka, 1999).

Ao estudar o município em seu aspecto urbano, agrário e regional, os estudantes aprendem o processo de construção da sociedade, isto é, como os seres humanos interagem e como se organizam para promover sua subsistência; eles compreendem a formação socioespacial de como a sociedade vive. Essas reflexões dialogam com a educação crítica, concepção elaborada por Paulo Freire em Pedagogia do Oprimido (1987). Para este educador, os processos formativos são importantes recursos de elaboração do conhecimento para a compreensão, interpretação e transforma- 


\section{Geografia, livro didático e educação: problematizações da temática agrária no ensino fundamental}

ção social. Assim, embora apresente limites, o saber crítico concebe uma possibilidade de intervir na realidade: "[...] quanto mais criticamente se exerça a capacidade de aprender, tanto mais se constrói e se desenvolve o que venho chamando "curiosidade epistemológica", sem a qual não alcançamos o conhecimento cabal do objeto" (Freire, 2002, p. 13).

$\mathrm{O}$ estudo precisa propiciar condições em que o estudante se vislumbre como integrante do que está estudando e como pertencente a uma realidade concreta, vivida cotidianamente, e não a coisas distantes e abstratas. Sendo assim, ao estudar o local, não se pode perder de vista os contextos regional, nacional e mundial, ou seja, a escala geográfica do acontecer histórico. $\mathrm{O}$ mundo não é uma somatória desses espaços estudados separadamente, de modo a ter sentido se for visto em sua totalidade, em sua interação escalar (Callai, 2003). No processo de construção do conhecimento, o estudante pode buscar uma maior interação com o espaço vivido, o envolvimento com problemas locais de modo a tornar-se um agente ativo e progressivamente consciente a produzir respostas adequadas aos desafios que interferem na vida cotidiana de sua comunidade. Neste sentido, representa uma possibilidade de ampliar sua compreensão de mundo; no lugar que vivemos, pisamos, é que podemos ter a real dimensão do universo (Callai, 2012).

A simultaneidade do mundo pode ser vista e vivida como coexistência dos lugares, onde o global e o local se unem em um processo dialético de produção do espaço (Santos, 1996). Em diversas regiões do Brasil, um mesmo rio pode ser disputado pelo capital hegemônico e pelas comunidades ribeirinhas, de modo que toda expansão do capital em áreas rurais próximas ou distantes dos centros dinâmicos da economia nacional, significa, por seu turno, a invasão nos territórios das comunidades rurais. Expansão e invasão conformam processos dialéticos que evidenciam as transformações conflitivas no espaço agrário.

Há inúmeras situações dessa natureza em todo o Brasil. $\mathrm{Na}$ Amazônia, a partir da construção das hidrelétricas do Madeira, no município de Porto Velho (Rondônia), e Belo Monte, em Altamira (Pará), várias comunidades ribeirinhas foram desterritorializadas, expropriadas pelo Estado e pelo capital hidroelétrico. Neste contexto, perspectivas diversas e excludentes se entrecruzam. Para os ribeirinhos da Amazônia, por exemplo, os rios significam fonte de vida, local de onde retiram o alimento para o sustento da família, o meio de transporte que lhes dá acesso a outras comunidades e cidades. Além de sua utilidade, acreditam que os rios carregam as histórias de seus antepassados, suas crenças e religiosidades, simbologias que estão presentes em seu dia a dia. Para os 


\section{Geografias de Rondônia Território, Fronteira e Educação}

atores hegemônicos, o rio é somente um meio para escoar suas mercadorias (no caso das hidrovias) ou produzir energia (no caso das hidrelétricas), com vistas ao processo de acumulação de capital e expropriação socioterritorial (Costa Silva, 2014).

Em temas como a migração, por exemplo, os conteúdos nos livros didáticos podem apresentar visões que produzem entendimentos discriminatórios. Evidências empíricas ancoradas em experiências com professores e professoras em sala de aula têm demonstrado que a concepção de migração pode ser entendida como uma "opção" natural do camponês de sair do campo e residir na cidade (Suave, 2019). Muitas vezes deparamo-nos com as seguintes frases dos estudantes: "Não adianta ficar na roça, a gente se mata de tanto trabalhar e as coisas da roça não têm valor" ou "Professora, tá virando tudo pasto". Esse tipo de concepção se perpetua com naturalização e fatalidade, como se a migração fosse algo sempre natural, ou ainda, como impossível de mudar.

Apesar dos apontamentos realizados pelos currículos oficiais, o trabalho do professor na seleção de conteúdo educacional é imprescindível. Na Amazônia, temas como o processo de colonização agrícola, expansão da fronteira agrícola, questões ambientais e econômicas, dinâmicas da população urbana e rural, migração e êxodo rural, povos originários e comunidades tradicionais, conflitos agrários, reforma agrária e territórios dos povos amazônicos, são todos pertinentes a serem desenvolvidos em sala de aula numa perspectiva multiescalar e multidimensional.

Dessa forma, temáticas como essas exigem intervenções pedagógicas problematizadoras, de modo que os estudantes possam compreender a existência de um conjunto de fenômenos ou um "campo de força" controlado por classes sociais/grupos de interesses que impulsionam modificações no território. As condições de moradia e emprego, economia, urbanização, meio ambiente, saúde, educação e qualidade de vida também refletem o processo de ocupação dos lugares em que vivem. Essas indagações objetivam problematizar, em vez de naturalizar, o que nos remete ao pensamento de Paulo Freire (1987; 2002), que argumenta ser o processo educativo uma forma de auxiliar na formação crítica, como "instrumento de libertação", permitindo a leitura da realidade voltada para o processo de mudança social, indo além do discurso ideológico de naturalização da história humana.

$\mathrm{Na}$ escala regional, estudos referentes à formação socioespacial de Rondônia, por um lado, apontam o protagonismo camponês pelo acesso à terra para a sua sobrevivência, isto é, que viu a terra como condição 


\section{Geografia, livro didático e educação: problematizações da temática agrária no ensino fundamental}

de vida, sobretudo no período da colonização agrícola (1970/1990). Por outro lado, os grupos econômicos veem a terra com intuito de extrair a maior quantidade de lucros (terra-negócio), os quais são comandados pelo capital globalizado, principalmente a partir da expansão do agronegócio (Costa Silva, 2010, 2012; Ribeiro, Costa Silva, Corrêa, 2015; Costa Silva; Conceição, 2017). Para uns, contemplou o aumento do capital e, para outros, a pobreza e a desigualdade socioespacial, além das pressões frequentes com efeito devastador na natureza e nos territórios do campesinato, dos povos indígenas e comunidades tradicionais, somadas às ações de violação aos direitos humanos e à educação do/no campo da/na Amazônia (Costa Silva; Neves, 2018; Lima; Costa Silva, 2018).

As diversidades culturais podem ser trabalhadas, segundo os PCNs, respeitando o conhecimento e a valorização das características étnicas e culturais dos diferentes grupos sociais que habitam o território nacional, as desigualdades socioeconômicas e a crítica às relações sociais discriminatórias e excludentes que permeiam a sociedade brasileira (Brasil,1998). Já o Referencial Curricular para o estado de Rondônia, no $6^{\circ}$ ano do ensino fundamental, diz ser necessário estudar os aspectos socioculturais dos povos indígenas, quilombolas e outros grupos étnicos, assim como, a modificação das paisagens, o modo de vida das populações tradicionais, considerando também a demarcação de terras para as comunidades remanescentes de negros escravizados no estado de Rondônia e os conflitos de interesses pelo uso e ocupação do território (Rondônia, 2020).

A questão exige uma abordagem dialógica e escalar em sala de aula, considerando que os conteúdos da geografia geral estão expostos nos livros didáticos distribuídos pelo MEC, enquanto os regionais/ agrários dependem quase que exclusivamente da ação do professor em pesquisar e produzir as temáticas em atividades pedagógicas para, então, estabelecer conexões com as diferentes escalas do espaço geográfico. Contudo, sem material didático sobre o agrário de Rondônia, os conteúdos identificados no referencial curricular do estado tendem a perder sua importância no contexto da geografia escolar.

Nessa situação, seria interessante que o professor produzisse seu material didático para suprir a falta dos conteúdos relacionados à escala regional e local do espaço agrário rondoniense, e, assim, contribuir para efetivar a proposta curricular no ensino de geografia. Sabe-se que o trabalho com conteúdo regionalizado demanda tempo de qualidade para o professor pesquisar (ter aportes teóricos e metodológicos), principalmente porque as novas propostas educacionais subtraem muito tempo do professor na resolução de tarefas burocráticas, o que potencializa seu 


\section{Geografias de Rondônia Território, Fronteira e Educação}

afastamento da capacidade criadora (intelectual) pelo fato de as escolas não fornecerem condições e incentivos à prática de leituras, pesquisas e qualificação docente.

As inquietações sobre o modo como a escola discute as temáticas geográficas, dentre as quais, a questão agrária, têm sido investigadas a partir de diferentes fontes e métodos, seja nos estudos que envolvem diversas preocupações, como as relações entre o livro didático e a prática pedagógica em Geografia (Azambuja, 2015); a linguagem cartográfica nos anos finais do ensino fundamental (Prado, 2014) e o livro didático como mediador dos saberes geográficos (Sales; Vinhal, 2013).

O livro didático é sem dúvida um grande instrumento de democratização do conhecimento geográfico. Todavia, em vários livros os conteúdos curriculares fazem fortes referências às políticas neoliberais, cuja maior preocupação é formar cidadão individualista, por vezes indiferentes aos problemas sociais e regionais. Muito embora o livro didático seja a principal guia de abordagem em sala de aula, os professores devem se ater às questões que possam indicar situações controversas que impliquem em uma leitura equivocada e marginalizada da situação geográfica. Algumas dessas situações serão analisadas na seção seguinte.

\section{TEMÁTICAS AGRÁRIAS NOS LIVROS DIDÁTICOS: UMA CRÍTICA AOS CONTEÚ- DOS ESCOLARES}

Para compreender a percepção de aprendizagem dos estudantes e suas referências de conhecimento, a pesquisa se propôs a verificar como os conteúdos curriculares do $6^{\circ}$ ano do ensino fundamental estão sendo trabalhados no planejamento anual da Escola Estadual de Ensino Fundamental e Médio Juscelino Kubitschek, município de Santa Luzia D'Oeste, estado de Rondônia. Essa investigação também nos direcionou a averiguar como as temáticas agrárias são abordadas no livro didático, principalmente ao verificar a aproximação do planejamento do professor com os conteúdos do livro didático intitulado Expedição Geográfica (Adas; Adas, 2015).

Os conteúdos curriculares passam por diferentes etapas em sua construção, sendo que uma delas é o currículo em ação, aquele que se torna exequível em sala de aula, ou seja, significa a "real proposta curricular", o momento em que o prescrito é apresentado, moldado e posto em ação na prática docente (Sacristán, 2000). Neste caso, o livro didá- 


\section{Geografia, livro didático e educação: problematizações da temática agrária no ensino fundamental}

tico tornou-se a única referência de aprendizagem no $6^{\circ}$ ano da referida escola pesquisada.

Na situação em estudo, os conteúdos a serem analisados estão respaldados na proposta do PCN, no eixo temático Campo e Cidade como Formação Socioespacial, previsto para o $3^{\circ}$ ciclo do ensino fundamental ( $6^{\circ}$ e $7^{\circ}$ anos). Geralmente os estudantes apresentam a faixa etária entre 11 e 13 anos, estando aptos a aprenderem sobre os diferentes usos desiguais do espaço, das disputas por recursos e territórios que expressam conflitos entre os modos de vida das sociedades (Brasil, 1998).

Ao analisar o livro do $6^{\circ}$ ano Expedição Geográfica percebe-se que, parcialmente, os temas estão de acordo com os PCNs e, até certo ponto, fazem o estudante pensar a sua realidade no cotidiano; os textos são curtos e quase todos têm imagens relacionadas aos conteúdos, o que permite uma leitura adequada à faixa etária; as representações gráficas e cartográficas complementam os textos e interagem com eles; as ilustrações são atraentes e os mapas temáticos contribuem para melhor compreensão dos conteúdos. Ainda no quesito infográfico, evidenciam-se ferramentas educacionais criativas e, de forma lúdica, trabalha-se a compreensão dos conteúdos de Geografia.

A análise pertinente ao livro, pontualmente, se relaciona à temática agrária e suas abordagens descritas na proposta curricular do livro do $6^{\circ}$ ano. Ao ministrarmos as temáticas que refletem sobre as questões agrárias é importante considerar o pensamento de Paulo Freire (1987; 2002), que argumenta ser o processo educativo uma forma de auxiliar na formação crítica, "instrumento de libertação", permitindo para além do discurso ideológico do capital, a leitura da realidade voltada para o processo de mudança social.

Tavares (2016) analisou a temática agrária no livro Expedição Geográfica, do $6^{\circ}$ ano, e concluiu que o livro destaca as atividades no campo do ponto de vista do agronegócio, focando na agricultura capitalizada/empresarial e, por conseguinte, abrandando a importância da agricultura camponesa/familiar, os movimentos sociais e a violência no campo: os autores deram ênfase à simples enumeração dos produtos cultivados no campo do ponto de vista do agronegócio. [...] foca apenas a descrição de conceitos relacionados à agricultura e reafirma a agricultura capitalista, deixando de lado discussões primordiais voltadas para a agricultura camponesa/familiar. 


\section{Geografias de Rondônia Território, Fronteira e Educação}

Os autores apresentam o extrativismo, a agricultura, a pecuária e os sistemas de produção agrícola dando destaque apenas para a agricultura moderna e seus complexos agroindustriais. [...] não é falado sobre os conflitos pela posse da terra, no Brasil e no mundo. $\mathrm{O}$ debate sobre os movimentos sociais no mundo também não aparece no livro. No Brasil, foi citado o caso da luta dos seringueiros na construção das reservas extrativistas, mas sem que a importância desse movimento na atualidade, enquanto resistência dentro do sistema capitalista fosse analisada ou destacada. Outro ponto a ser analisado é a forma em que o campo é tratado: como uma área estritamente de produção. Sua paisagem é retratada apenas com fotografias de área produtivas (Tavares, 2016, p. 55).

Os conteúdos agrários trabalhados no livro didático (LD) Expedição Geográfica, do $6^{\circ}$ ano, relacionados ao tema "Agricultura" são tratados como uma área estritamente de produção agropecuária, uma visão setorial. A paisagem rural é retratada apenas com imagens de áreas produtivas, não tendo sido observados assuntos, imagens e citações que mencionassem o espaço do camponês, rico em cultura, espaço de vivências e de festejos.

Neste contexto, para fins da pesquisa, mediou-se vários temas do livro com os conhecimentos dos estudantes, cujo objetivo foi aproximar o mundo escrito no livro e o lugar vivido dos alunos. Assim, os temas i) trabalho e produção de alimentos, ii) modo de vida da população indígena, iii) movimentos sociais no campo (MST) e iv) mulheres trabalhadoras rurais foram escolhidas para articular os conteúdos abordados no livro com as vivências e leituras do mundo dos estudantes.

\section{Trabalho E PRODUÇão de alimentos}

A temática produção de alimentos é muito importante para os estudantes, considerando que muitos são moradores ou migrantes da área rural. Nesse sentido, foi encaminhado um questionário de pesquisa aos 64 estudantes do $6^{\circ}$ ano, salientando que $44 \%$ deles são moradores da área rural do município de Santa Luzia D'Oeste, com faixa etária entre 12 e 14 anos. $\mathrm{Na}$ oportunidade, os estudantes foram indagados se sabiam de onde vêm a maioria dos alimentos que chegam as nossas mesas (Gráfico 1). 
Geografia, livro didático e educação: problematizações da temática agrária no ensino fundamental

Gráfico 1 - Respostas acerca de onde vem os alimentos (2019).

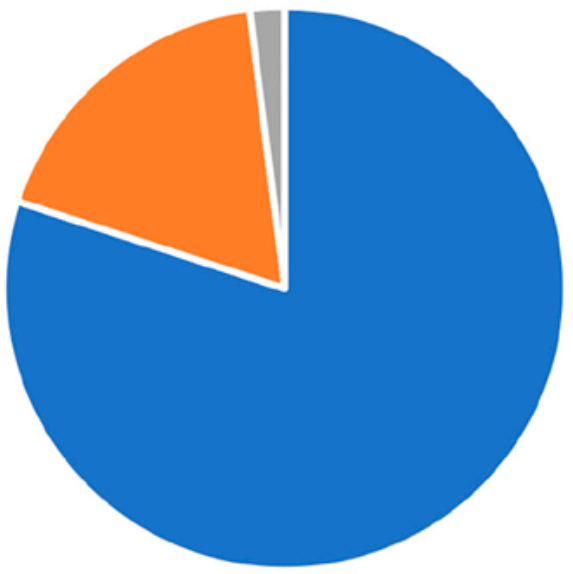

- Agronegócio = Agric. Familiar = Indústrias

Fonte: Dados da pesquisa (Suave, 2019).

De imediato, os estudantes declararam que se tratava de uma pergunta de fácil resposta ao se referirem à propaganda sobre o agronegócio exibida na Rede Globo de Televisão, que tem como slogan "Agro é Tech, Agro é Pop, Agro é Tudo". Essa campanha publicitária, iniciada em junho de 2016, busca captar a atenção dos telespectadores ao aglomerar uma combinação de elementos que reforçam a imagem positiva do agronegócio, que passa a ser o único produtor de alimento no Brasil, com música atraente, sequência de closes trazendo o colorido das plantações e a modernidade do maquinário, além de transmitir a "alegria" de quem mora no campo (Carvalho, 2014).

É possível inferir que os estudantes, por um lado, tenham acesso a muitas informações direcionadas à construção de representações sociais, cujos interesses nem sempre visam melhorar as condições de vida da sociedade. Essas representações do cotidiano vivido se manifestam em suas percepções de aprendizagem. O livro do $6^{\circ}$ ano Expedição Geográfica discute o tema solicitando aos leitores compararem dois modelos de produção agrícola a partir de técnicas e instrumentos usados no cultivo da lavoura, conforme explicitado na (Figura 1). A primeira imagem, de tamanho menor, evidencia uma representação de um traba- 


\section{Geografias de Rondônia Território, Fronteira e Educação}

lhador rural (lavrador) com equipamentos tradicionais $80 \% 18 \% 2 \%$ - Agronegócio Agricultura Familiar Indústrias - usados para o trabalho no cultivo da terra. De outro lado, em perspectiva ampliada, há uma imponente imagem de uma colheitadeira de soja.

Figura 1 - Os sistemas de produção agrícola.

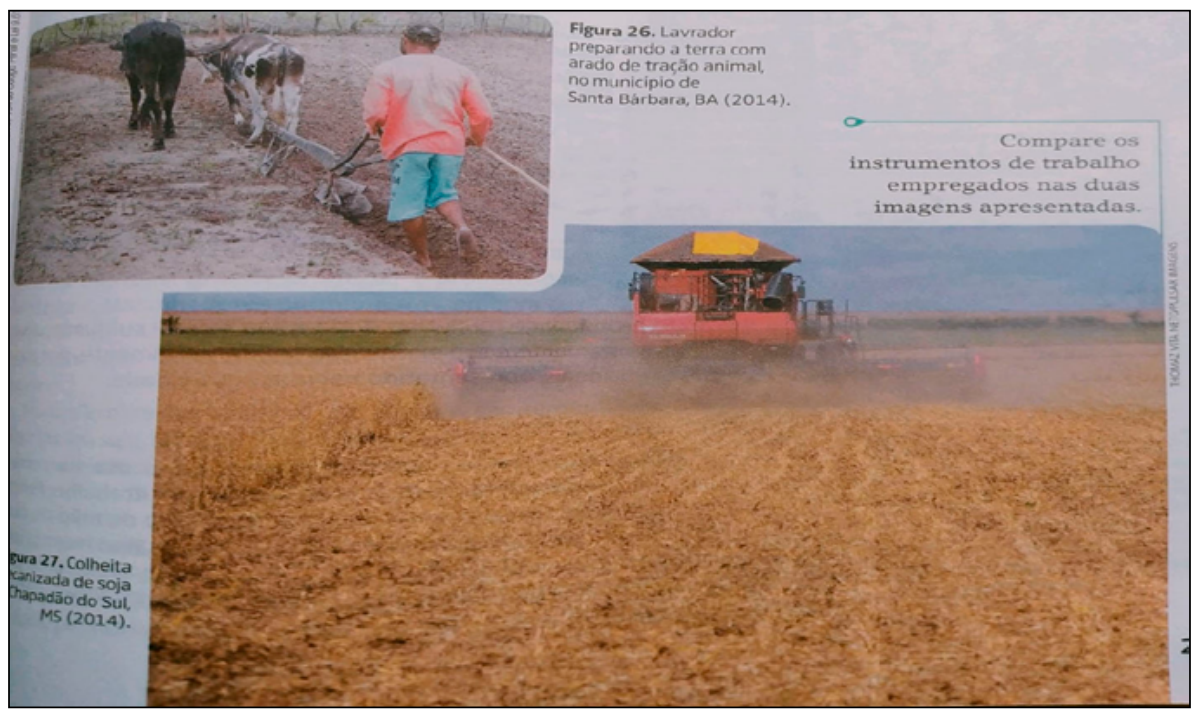

Fonte: Adas; Adas, 2015, p. 223. ( $6^{\circ}$ ano). Figura escaneada.

A própria desproporcionalidade nas imagens já sugere uma hierarquização nos formatos de produção e informa status de inferioridade e superioridade. $\mathrm{Na}$ imagem relacionada ao pequeno agricultor, localizado no interior nordestino, a técnica adotada para o trabalho na terra é o tradicional arado de tração animal. Essas evidências nos levam a deduzir que há uma explícita desqualificação da unidade agrícola camponesa, considerando que a produção familiar é a responsável direta por boa parte dos alimentos que estão na mesa do povo brasileiro. Sendo assim, os estudantes podem ser levados a pensar que o camponês representa o "atraso", o antigo, e que precisa "sair de cena" para dar espaço ao moderno, neste caso, ao agronegócio. Nesse sentido, independente da proposta didática do livro, a imagem por si revela a inferioridade e a desvalorização do trabalho familiar, ao tempo em que enaltece o trabalho com tecnologia do agronegócio, contudo, não há problematizações 


\section{Geografia, livro didático e educação: problematizações da temática agrária no ensino fundamental}

referentes às relações de trabalho e de expropriação socioterritorial e impactos ambientais que o agronegócio promove no campo.

A atuação da docência na área de educação em geografia pode ampliar a problematização sobre a questão da produção de alimentos, analisando as respostas dos estudantes em comparação com as formas tecnológicas do trabalho, as desigualdades regionais e a sustentabilidade ambiental e agrícola. Momentos como estes representam oportunidades à discussão de estereótipos comumente veiculados por meio de imagens que apresentam determinadas realidades congeladas, como se fossem definidas apenas por aquelas características. É uma forma também de recusar a dinamicidade do processo nas pequenas unidades de produção agrícola e a universalidade social e produtiva do campesinato. Nesse sentido, cabe destacar a questão do estereótipo enquanto mecanismo de representação social:

[...] o estereótipo não é uma simplificação porque é uma falsa representação de uma dada realidade. [...]. É uma simplificação porque é uma forma presa, fixa, de representação que, ao negar o jogo da diferença (que a negação através do Outro permite), constitui um problema para a representação do sujeito em significações de relações psíquicas e sociais (Bhabha, 1998, p. 117).

É perceptível que o livro didático analisado através desta atividade em discussão não reflita ou não deseje refletir as mudanças ocorridas na agricultura camponesa; que o desenvolvimento das atividades agrícolas envolve recursos existentes na própria propriedade, os quais são autogeridos e dizem respeito à mobilização tanto dos recursos sociais quanto dos naturais. Assim, o camponês possui uma relação com e de proteção à natureza de forma mais adequada, traduzida no manuseio das plantas, do solo e dos nutrientes, por exemplo. Nesta concepção, a terra e a família compõem, então, os pilares centrais da base de recursos, não só do ponto de vista material, como também do simbólico, vindo dessas relações a centralidade da terra nas lutas campesinas.

\section{MOdo DE VIDA DA POPUlAÇÃO INDÍGENA, QUILOMBOLA E RIBEIRINHA}

A segunda questão dirigida aos estudantes indagava se conheciam o modo de vida da população indígena, de comunidades quilombolas e 


\section{Geografias de Rondônia Território, Fronteira e Educação}

ribeirinhas. A intenção foi verificar os conhecimentos que possuíam referente aos sujeitos coletivos e seus territórios. A maioria dos estudantes não lembrou de ter estudado esse tema, como se verifica no gráfico 2 .

Gráfico 2 - Conhecimentos dos estudantes - Povos originários da Amazônia.

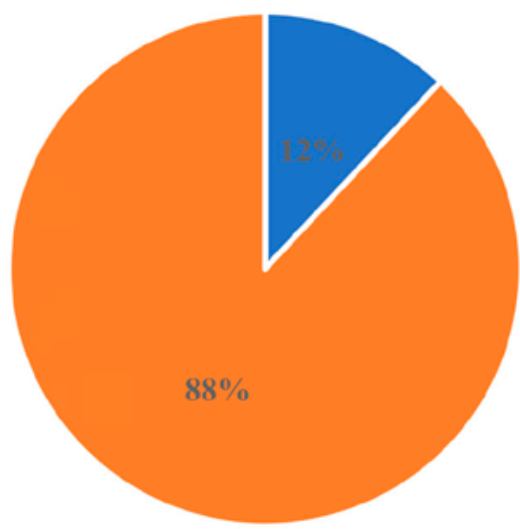

- Lembram ter estudado a populaçao indígena, quilombolas e ribeirinhas

- Não lembram ter visto este tema

Fonte: Dados da pesquisa (Suave, 2019).

Seguindo o procedimento anterior, foi verificado como esse tema é tratado no livro didático Expedição Geográfica, material utilizado pelos estudantes participantes da pesquisa. As repostas dos estudantes indicam que $88 \%$ não lembraram de ter estudado esse tema em sala de aula, ao passo que somente $12 \%$ afirmaram ter estudado alguns temas relacionados. Ressalta-se que os estudantes vivem na Amazônia, região composta por inúmeros povos indígenas e comunidades tradicionais. Em Rondônia, a questão indígena aparece na mídia regional em temas complexos que abordam situações relacionadas à saúde, educação, cultura e invasões dos territórios dos povos amazônicos.

No exemplo retirado do livro didático (Figura 2), verifica-se um grupo de indígenas pertencente à etnia Kamaiurá, localizada no Parque Nacional do Xingu (Mato Grosso). Algumas análises apontam que a 


\section{Geografia, livro didático e educação: problematizações da temática agrária no ensino fundamental}

forma como o livro didático representa as sociedades indígenas evidencia desconhecimentos e alheamentos sobre suas formas de viver:

[...] os índios fazem canoas, andam nus, gostam de se enfeitar e comem mandioca, mas poucos falam a respeito da complexidade da vida dessas sociedades, dos rituais, das relações desses povos com o ambiente natural, com suas concepções de mundo (Printes, 2014, p. 202).

É possível observar que o livro, ao tratar dos povos indígenas, identifica seu pertencimento étnico e localização, um aspecto importante que leva em conta as exigências da Lei 11.645/2008. De acordo com essa normativa, os currículos escolares devem inserir em suas pautas formativas conhecimentos e contribuições das sociedades indígenas no processo pretérito e atual da formação do Brasil (Brasil, 2008; Neves, 2013).

Figura 2 - Pesca na Aldeia Kamayurá no Parque em Xingu.

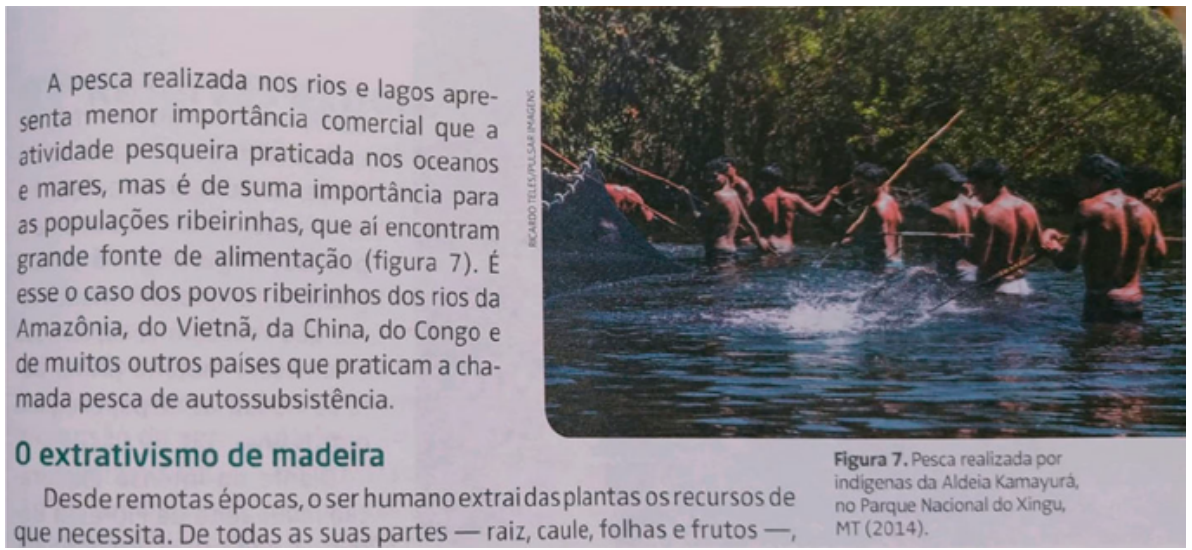

Fonte: Adas, 2015, p. 211. ( $6^{\circ}$ ano). Figura escaneada.

A leitura mais atenta do texto constata que o tema pesca tem relação direta com a imagem referente ao povo Kamayurá e suas técnicas próprias de produzir sobrevivência. O livro limita-se apenas a um amontoado de informações sobre a pesca realizada por microssociedades, como prática que difere da grande produção. 


\section{Geografias de Rondônia Território, Fronteira e Educação}

Deste modo, o livro didático Expedição Geográfica, além de não ter aprofundado a importância da pesca no contexto da etnia Kamayurá, como uma prática milenar de sobrevivência e territorialidades e, a partir daí, confrontar com outras formas culturais históricas, não questionou as ameaças que pairam sobre os territórios indígenas, principalmente no que diz respeito às constantes invasões destas áreas para a pesca e caça ilegal. Considerando o contexto amazônico, temas dessa natureza devem ser discutidos, sobretudo, em função da expansão das fronteiras agrícolas que significa invasão das áreas indígenas desencadeando tensões e conflitos. No que tange aos aspectos relacionados à perspectiva histórica, silencia a presença e intensidade da vida social indígena e as relações humanas nas aldeias e de preservação da natureza.

É comum observar em publicações referentes aos povos indígenas, denúncias de preconceito e discriminação sobre o modo de viver das etnias brasileiras (Neves, 2013). É necessário que o estudante, no âmbito dos saberes geográficos, aprenda sobre a importância da cultura desses povos e que tenham condições de reconhecer suas contribuições para as representações simbólicas da identidade sociocultural do território brasileiro, principalmente em Rondônia, além da importância de suas permanências nos territórios estabelecidos.

\section{Movimento dos Trabalhadores Rurais Sem Terra}

A terceira pergunta da pesquisa se referiu ao conhecimento e/ou informações referentes ao Movimento dos Trabalhadores Rurais Sem Terra (MST). Solicitou-se aos estudantes que informassem o que conheciam a respeito desse movimento social, suas reivindicações e como compreendem a frase "luta pela terra justa". Conforme Gráfico 3, apurou-se que $27 \%$ dos estudantes alegaram já ter ouvido falar sobre o MST e $64 \%$ não, e apenas $9 \%$ dos estudantes disseram ser justas as reivindicações pela reforma agrária.

No conjunto, algumas respostas reproduziram a mesma interpretação do senso comum veiculada por grandes especuladores de terras e mídia corporativa, a de que os membros deste Movimento são invasores, bandidos e violentos. Em função dessa visão, desaprovam as ocupações de terras realizadas pelo movimento.

De certa forma, são compreensíveis tais entendimentos, considerando a faixa etária estudantil, somada aos conteúdos pouco abrangentes no livro didático. Por isso, se faz necessária uma leitura mais 
Geografia, livro didático e educação: problematizações da temática agrária no ensino fundamental

ampliada da questão da terra e dos conflitos agrários, com mediações progressivas e intervenções pedagógicas do professor com o fito de trazer outros elementos socioeconômicos inerentes à temática sobre movimentos sociais no campo, como a reforma agrária, concentração fundiária e acesso à terra pública no Brasil. Essas mediações são imperativas, dado que os conflitos agrários e territoriais ganham relevância na Amazônia e no estado de Rondônia.

Gráfico 3 - Conhecimentos dos estudantes sobre o MST.

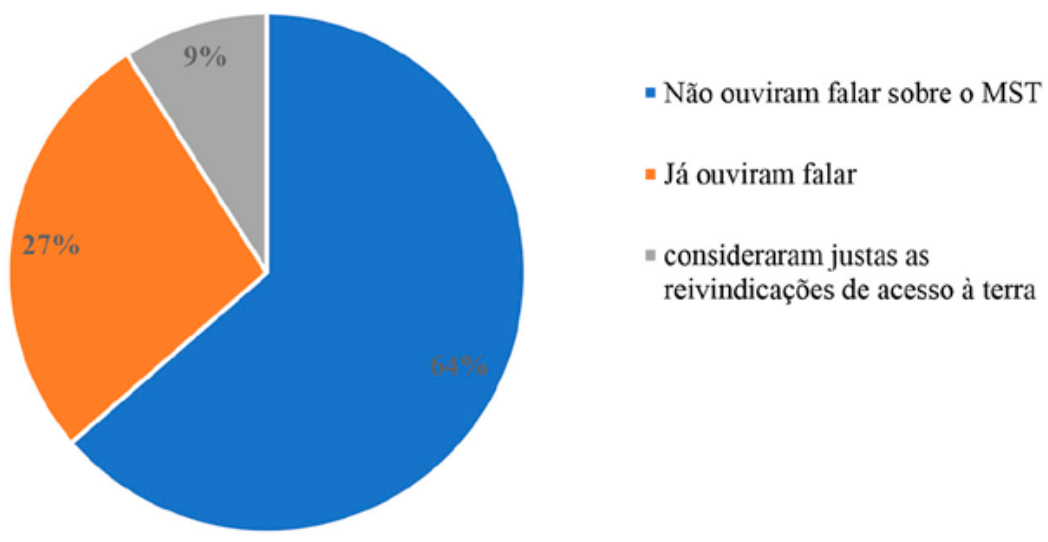

Fonte: Dados da pesquisa (Suave, 2019).

Essas respostas (Gráfico 3) permitiram entender o quanto é necessário rediscutir as aprendizagens críticas e necessárias no ambiente escolar. Uma proposta que se aproxime do que Torres Santomé nomeou de justiça curricular, uma proposição de trabalho pedagógico que: “[...] exige questionar se as interações pessoais nas salas de aula e na escola, assim como os modelos de participação estão condicionados por preconceitos e falsas expectativas; [...]". (Torres Santomé, 2013, p. 9). Uma oportunidade pedagógica a problematizar como operam as estruturas de dominação e exploração de viés colonial que em muitas situações, “[...] mantém não só a estrutura fundiária, a repressão violenta aos que lutam; mas, também, a "imagem negativa" de alguns movimentos sociais perante o restante da sociedade" (Silva; Archanjo, 2019, p. 29). 


\section{Geografias de Rondônia Território, Fronteira e Educação}

Um modelo formativo que permita a inclusão de temas considerados polêmicos, como o MST, que encontre na pauta escolar possibilidades de compreensões de outras $64 \%$ 27\% 9\% Não ouviram falar sobre o MST Já ouviram falar consideraram justas as reivindicações de acesso à terra lógicas socioterritoriais, próprias da tarefa educacional emancipadora; Compreender que o MST constitui uma das maiores organizações sociais do país em defesa da reforma agrária, e que nesta direção tem assumido a tarefa de questionar o latifúndio e a concentração fundiária como raízes das desigualdades sociais, representa uma aprendizagem fundamental do trabalho geográfico crítico.

Embora parte significativa dos estudantes participantes do estudo seja oriunda de pequenas propriedades da zona rural, como já mencionamos neste trabalho, isso não parece repercutir em suas leituras sobre as desigualdades existentes no tocante à gestão da terra e sua gigantesca assimetria. Análises da educação crítica interpretam esses comportamentos como ecos da subalternização que só podem ser revistos com problematizações emancipadoras:

O grande problema está em como poderão os oprimidos, que "hospedam" ao opressor em si, participar da elaboração, como seres duplos, inautênticos, da pedagogia de sua libertação. Somente na medida em que se descubram "hospedeiros" do opressor poderão contribuir para o partejamento de sua pedagogia libertadora (Freire, 1987, p. 20).

A causa predominante dos focos de violência encontra-se nos problemas de grilagem de terras públicas pelos latifundiários e invasões de Áreas Protegidas (Unidades de Conservação, Terras Indígenas e Terras Quilombolas), regularização fundiária e morosidade pública para a consolidação de projetos de assentamento em terras públicas destinadas à reforma agrária. As invasões às Terras Indígenas e Quilombolas, assim como aos territórios das comunidades tradicionais amazônicas, em geral, são provocadas pela agrobandidagem, exploração ilegal de madeira, mineração, grilagem de terras e diversos crimes ambientais que geram conflitos com os camponeses e povos amazônicos. Esta temática não foi identificada no livro Expedição Geográfica, do $6^{\circ}$ ano, silêncio que recusa evidenciar as desigualdades sociais e fundiárias no campo brasileiro. 


\section{Geografia, livro didático e educação: problematizações da temática agrária no ensino fundamental}

\section{Mulheres TrabalHadoras RURAIS}

A quarta pergunta recorreu às memórias dos estudantes sobre as imagens de mulheres trabalhadoras rurais no livro Expedição Geográfica, indagando-os se conheciam mulheres com esses perfis, ou seja, atuantes em atividades rurais. A intenção foi compreender se havia reconhecimento social expresso nos livros didáticos referente às mulheres e o mundo do trabalho na atualidade. Os resultados obtidos informaram que $83 \%$ dos estudantes não lembravam de ter visto tais imagens de mulheres trabalhadoras rurais, mas $100 \%$ dos entrevistados disseram conhecer mulheres que desenvolvem trabalho na pecuária e em atividades de plantio de alimentos.

Costa (2011) pesquisou livros didáticos de Geografia das escolas públicas a fim de detectar onde e de que forma está presente o tema de gênero, com a intenção de demonstrar a participação da mulher na construção do espaço geográfico, seu papel na divisão do trabalho e na produção de riqueza. Uma das conclusões da autora foi constatar a ausência de conteúdos que retratam questões sociais que envolvam o gênero feminino. Segundo a autora, quando o livro se refere a esse tema é de maneira superficial ou se encontra em atividades complementares, ficando a critério dos professores trabalharem ou não as temáticas e seus desdobramentos sociais.

Mas o que o livro Expedição Geográfica tem a dizer sobre o assunto? Foi possível localizar que o referido material faz referência à questão de gênero no meio rural, por meio da representação do trabalho de uma mulher quilombola e quebradeira de coco (Figura 3). Entretanto, observa-se que o texto não menciona suas atividades econômicas, nem a sua importância como contribuição significativa na renda familiar, além de deixar oculta a importância de políticas públicas destinadas às mulheres que vivem no campo.

Assim, as mulheres rurais têm uma longa trajetória de lutas, mas seu papel no campo ainda é considerado um trabalho doméstico, e o trabalho no roçado é, portanto, invisível, sem reconhecimento social, muito embora diversas pesquisas e lutas sociais vêm indicando transformações nessa questão social (Rossini, 1988; Nascimento Silva, 2012). Conforme dados do IBGE (2010), as mulheres representam 47,4\% da população rural brasileira, tendo um papel estratégico na produção de alimentos, na agricultura familiar, a qual abastece mais de $70 \%$ do consumo de alimentos dos brasileiros. No Brasil, os dados indicam a existência de 15 milhões de trabalhadoras rurais atuando na agricultura e na pecuária 


\section{Geografias de Rondônia Território, Fronteira e Educação}

em todo o Brasil. Há que se enfatizar a relação da mulher no processo produtivo, quando utiliza técnicas menos agressivas ao meio ambiente (adubos orgânicos), principalmente na plantação de hortaliças e leguminosa que serão consumidas pela família.

Figura 3 - Mulher quilombola quebradeira de coco babaçu.

Beneficiamento
Processo de tratamento
de matérias-primas que
consiste em descasque,
limpeza, polimento,
descaroçamento e
separasăo, a fim de
torná-las próprias para
o consumo.

Fonte: Adas; Adas, 2015, p. 208. ( $6^{\circ}$ ano). Figura escaneada.

Como já mencionado, as mulheres são consideradas importantes aliadas para a busca do desenvolvimento sustentável. Neste sentido, é preciso provocar essa discussão no meio educacional, sobretudo no ensino da Geografia, ao considerá-las importantes tanto na organização e produção agrícola quanto nas mobilizações dos movimentos sociais do campo. As disparidades de conteúdo e imagens entre o feminino e masculino no LD de Geografia, principalmente no meio rural, reforçam a invisibilidade das mulheres na produção de alimentos, contradizendo a realidade, pois, segundo informativos da FAO:

As mulheres rurais, por exemplo, representam $45 \%$ da força de trabalho agrícola em países em desenvolvimento como Brasil, chegando a $60 \%$ em partes da África e da Ásia. São responsáveis por mais da metade da produção 


\section{Geografia, livro didático e educação: problematizações da temática agrária no ensino fundamental}

de alimentos e também desempenham um importante papel na preservação da biodiversidade, garantindo a soberania e a segurança alimentar a partir da produção de alimentos saudáveis (Zavala, 2019, p. 1).

Portanto, a pesquisa realizada com os estudantes confirma tais contradições quando quase todos afirmaram não ter visto mulheres agricultoras nos livros didáticos, embora todos tenham confirmado a existência delas.

\section{LIVRO DIDÁTICO E CONTEÚDOS AGRÁRIOS E REGIONAIS: QUAIS CAMINHOS?}

Os conteúdos de geografia agrária analisados nas temáticas do livro do $6^{\circ}$ ano Expedição Geográfica não explicitaram a complexidade que envolve o campo brasileiro, sobretudo na região amazônica. Como anteriormente afirmado, o livro didático não tem como abordar todas das temáticas envolvendo as disciplinas, o que se impõem o recorte epistemológico e didática assentado na proposição do livro. Cabe então aos professores analisarem os fundamentos teóricos dessas proposições e verificar a melhor abordagem de ensino-aprendizagem. Então, qual a saída a essas questões? Quais caminhos?

A primeira questão é a análise, pelos professores, do LD em suas bases teóricas, conceituais e metodológicas que guiam a lógica dos conteúdos e do ensino proposto. Desse modo, é importante conhecer o método de pesquisa adotado pelo(as) autor(es/as) dos livros didáticos e seu posicionamento teórico/político (Bem, 2011), bem como analisar como o livro aborda os distintos interesses sociais pela terra, ou seja, os latifundiários e capitalistas do campo organizam a terra como mera mercadoria, geradora de capital, especulação e poder, enquanto os camponeses têm a terra como trabalho, morada e vivência. $\mathrm{O}$ autor solicita aos professores que observem a coerência da conexão entre os conteúdos, como é o caso da questão ambiental, do "uso do solo, do financiamento público, os conflitos de classe e a luta pela terra, a apropriação desigual do território e as diferentes escalas de poder local, regional, nacional e internacional" (Bem, 2011, p. 140). Essas interconexões são importantes e indissociáveis no processo de transformação do espaço agrário.

Portanto, ao analisar o manual didático antes da escolha do LD, deve-se averiguar se os conteúdos sinalizam para a potencialidade de temas atinentes e relevantes dos processos sociogeográficos e das territorialida- 


\section{Geografias de Rondônia Território, Fronteira e Educação}

des que envolvem as campesinidades, os povos indígenas e as comunidades tradicionais que vivem no espaço agrário brasileiro. Por fim, deve-se observar se o LD enfatiza a importância da agricultura camponesa/familiar para o desenvolvimento socioeconômico e ambiental do país. Seria interessante que os professores pudessem responder às seguintes questões:

I - O livro didático prioriza as relações sociais de produção no campo ou, os produtos do campo? II - O(s) autor(es) faz(em) a distinção entre o modelo e o desenvolvimento territorial baseado em grandes propriedades (latifúndio) do modelo de pequenas propriedades (agricultura camponesa)? III - Os conteúdos de geografia agrária são trabalhados de forma integradora, buscando a totalidade espacial por meio do estudo da questão da estrutura fundiária e da formação socioeconômica do país, das relações sociais de produção no campo, da monopolização do território pelas multinacionais, dos impactos ambientais causados pelo modelo do agronegócio, da resistência dos movimentos sociais e a luta pela terra? VI - O manual didático faz uma discussão crítica sobre a concentração de terras, buscando demonstrar ao leitor que a terra no Brasil é uma relação de poder; que existem enormes latifúndios no Brasil que pertencem a grupos empresariais de capital nacional e internacional; que a mesma gera desigualdade social e violência no campo? $\mathrm{V}-\mathrm{O}$ livro didático prioriza a necessidade de uma Reforma Agrária no Brasil, demonstrando aos estudantes a questão da sua viabilidade enquanto política de Estado, para promoção do desenvolvimento social e econômico do país, ou, se faz uso de argumentos para demonstrar os problemas de tal reforma nos dias atuais? VI - Como a agricultura camponesa é retratada no manual didático: a) Como mera produtora de alimentos para o mercado interno, como símbolo do atraso, personificada na pobreza do campo? b) Como modelo de desenvolvimento territorial que pressupõe o incremento da população no campo, que através da produção agropecuária garante a soberania alimentar do país? (Bem, 2011, p. 139).

A análise criteriosa e o posicionamento político e epistemológico dos professores devem ser considerados, na medida em que a escolha do livro didático em muitas situações, de maneira direta ou indireta, subtrai diversos temas/conteúdos em detrimento de outros, o que pode obliterar 


\section{Geografia, livro didático e educação: problematizações da temática agrária no ensino fundamental}

a realidade vivenciada pela maioria da população que vive nos campos do Brasil.

Outro caminho é a produção de materiais/livros adicionais didáticos e paradidáticos, financiado pelas secretarias estaduais de educação, referente aos conteúdos regionais, urbanos e agrários dos estados e região com o fito de auxiliar os professores a ensinarem aos estudantes o mundo que a eles está mais próximo. O mundo dos lugares, do campo e da cidade, dos territórios das diversas comunidades tradicionais e povos originários, assim como, a proteção

Tais produtos poderiam ser elaborados por universidades e grupos de pesquisas no âmbito de uma construção curricular que aproxime a universalidade do mundo ao cotidiano dos lugares, do espaço vivido dos estudantes. Ainda assim, é possível que outros tantos temas importantes não estejam contemplados em propostas regionais, contudo, não deixam de ser uma contribuição à proposição de material didático e paradidático com abordagem do lugar e região dos sujeitos da escola. Evidentemente, isso requer investimentos públicos.

O terceiro caminho é a formação no nexo pesquisa-ensino para os professores. Sabe-se que há muitos programas de formação continuada que atingem a rede pública de ensino, o que tem demandado tempo de dedicação dos professores e os sobrecarregados em sala de aula. Mas, um programa de formação focado na pesquisa, na construção do conhecimento e nos acessos às informações e dados inerentes aos conteúdos propostos nos livros didáticos certamente pode contribuir com a melhoria da qualidade de ensino-aprendizagem. Evidentemente, as escolas precisam ser esse espaço de formação intelectual, um laboratório do saber e da vida, onde os docentes possam construir suas experiências didáticas e teóricas, ou seja, precisam estar equipados para essa ação.

No plano do ensino-aprendizagem, a soma desses caminhos pode oportunizar que os estudantes fomentem a construção de um olhar crítico, minucioso e questionador referente à atual dinâmica agrária que vem se consolidando na Amazônia, principalmente em Rondônia, de modo a possibilitar que esses estudantes se veem como parte integrante do lugar de vida, da cidade, do campo e da floresta.

No que se refere à defesa dos povos amazônicos, é necessário que os estudantes compreendam as representações simbólicas das identidades socioculturais e dos grupos étnicos, entenderem seus costumes e tradições, e como são compartilhados entre as gerações. É reconhecível que o primeiro passo para a destruição da identidade desses povos 


\section{Geografias de Rondônia Território, Fronteira e Educação}

está na destruição de seus territórios. Contudo, um dos maiores problemas enfrentados pelos povos indígenas e comunidades tradicionais e camponesas está na falta de demarcação e regularização de suas terras. Já com a situação da população indígena é mais difícil ainda, visto que, mesmo em condições de regularização oficial desses territórios, tem ocorrido a invasão de garimpeiros, madeireiros, grileiros e a expansão do agronegócio.

\section{CONSIDERAÇÕES FINAIS}

A finalidade deste estudo foi analisar como os conteúdos que retratam as temáticas agrárias no livro didático estão em dialogia com as perspectivas estudantis em relação ao mundo vivido, na escala local do acontecer histórico. Para isso, algumas temáticas foram escolhidas por serem pertinentes aos lugares de morada, da vida cotidiana. A conclusão indica um descompasso entre as visões dos estudantes e as explicações expostas no livro Expedição Geográfica, uma vez que poucas aprendizagens críticas foram construídas e relacionadas ao espaço vivido, à escala local e regional.

Em muitas situações, à docência na área da geografia reproduz veiculações dos livros didáticos que preconizam um ideário de agricultura capitalizada, pari passu, os conteúdos referentes aos territórios do campesinato, dos povos indígenas e comunidades tradicionais rurais, muitas vezes são ocultados ou pouco destacados nos textos e imagens, além de, em alguns contextos, distorcerem a realidade. O modelo de produção agrícola eleito para ser destaque em alguns livros didáticos é marcado por grandes interesses econômicos que, ao (des)organizar o território, desencadeiam diversos problemas de ordem social, econômica e ambiental. Esses fatos devem ser amplamente discutidos em sala de aula. Sendo assim, é de extrema importância que o professor, ao selecionar o livro didático, verifique como os autores abordam os distintos interesses sociais pela terra e natureza.

No que concerne aos conteúdos de geografia agrária, muitos deles não contemplam as relações sociais de produção no campo, os impactos socioambientais causados pelo agronegócio, assim como não fazem análises consistentes sobre a concentração de terra, desigualdades sociais e violência no campo, não priorizam a necessidade de uma reforma agrária no Brasil, com objetivo de demonstrar aos estudantes a questão de sua viabilidade enquanto política de Estado para a promo- 


\section{Geografia, livro didático e educação: problematizações da temática agrária no ensino fundamental}

ção do desenvolvimento social, econômico e de produção soberana de alimentos no Brasil.

As percepções de aprendizagem dos estudantes de $6^{\circ}$ ano resultantes da pesquisa realizada constatam que a referência de conhecimento acerca das questões agrárias se aproxima daquelas descritas pelo livro, que postula uma visão cunhada nas expectativas das políticas neoliberais, como a agricultura empresarial, esquecendo-se de problematizar as consequências que esse modelo de produção agrícola exerce no espaço agrário em todo Brasil, principalmente na Região Amazônica. Sem outras referências de "conhecimento", os estudantes não conseguem fazer uma leitura das mudanças territoriais que desencadeiam drásticas alterações na estrutura agrária do estado, com repercussões impactantes em seus próprios espaços de vivência.

Por fim, alguns caminhos foram indicados: aos professores, deve-se fazer análises criteriosas dos livros didáticos para que os temas e conteúdos possam fazer abordagens qualificadas das diversidades do campo brasileiro, no sentido de permitir ao estudante a aproximação conceitual, factual e escalar dos conteúdos estudados; a produção de material didático e paradidático regional financiados pelas Secretarias Estaduais de Educação; formação continuada dos professores com o foco na pesquisa ensino-aprendizagem, sendo a escola o espaço desse processo.

\section{REFERÊNCIAS}

ADAS, M.; ADAS, S. Expedição Geográfica. 2. ed. v. 6 ano, São Paulo: Moderna, 2015.

AZAMBUJA, L. D. de. O livro didático e o ensino de geografia do Brasil. Revista Brasileira de Educação em Geografia, 4(8), 11-33. Disponível em; www.revistaedugeo.com.br. Acesso em: 13 jul. 2020.

BEM, A. A. Geografia agrária nos livros didáticos: primeira aproximação para uma crítica do conteúdo que ensina na escola. Rev. Ens. Geogr., Uberlândia,v. 2, n. 3, p. 137-150, jul./dez. 2011. Disponível em: www. revistaensinogeografia.ig.ufu.br. Acesso em: 30 abr. 2021.

BHABHA, H. O local da cultura. 2. ed. Belo Horizonte: Editora UFMG, 2013.

BRASIL. Instituto Nacional de Geografia e Estatística. Análise de gênero no espaço rural. Brasília: IBGE, 2010. Disponível: https://biblioteca. ibge.gov.br. 


\section{Geografias de Rondônia Território, Fronteira e Educação}

BRASIL. Lei n. 11.645/2008. Inclusão no currículo oficial da rede de ensino a obrigatoriedade da temática "História e Cultura Afro-Brasileira e Indígena". Brasília, 2008. Disponível em: www.planalto.gov.br. Acesso em: 13 jul. 2009.

BRASIL. Ministério da Educação. Secretaria de Educação Fundamental. Parâmetros curriculares nacionais: geografia $\left(3^{\circ}\right.$ e $4^{\circ}$ ciclos do ensino fundamental). Brasília: MEC,1998.

CALLAI, H. C. A formação do profissional da Geografia. Ijuí: Ed. Unijuí, 2013.

CALLAI, H. C. Estudar o lugar para compreender o mundo. In: CASTROGIOVANNI, A. C. (org.). Ensino de geografia: práticas e textualização no cotidiano. Porto Alegre: Mediação, 2009. p. 83-134.

CALLAI, H. C. O estudo do município ou a geografia nas séries iniciais. In: CASTROGIOVANNI, A. C.; CALLAI, H. C; SCHÄFFER, N. O.; KAERCHER, N. A. Geografia em sala de aula: práticas e reflexões. 4. ed. Porto Alegre: UFRGS/AGB, 2003.

CALLAI. H. C. Educação geográfica: ensinar e aprender geografia. In: CASTELHAR, S. M. V.; MUNHOZ, G. B. (org.). Conhecimentos escolares e caminhos metodológicos. São Paulo: Xamã, 2012. p. 73-87.

CARVALHO, F. A. de. Agronegócio, mídia e ensino de geografia. Dissertação (Mestrado em Geografia) - Programa de Pós-Graduação em Geografia, UEL, Londrina, 2014.

CAVALCANTI, L. S. Geografia escolar na formação e prática docentes: o professor e seu conhecimento geográfico. In: SILVA, A. M. M. et al. Educação Formal e não formal, processos formativos, saberes pedagógicos: Recife: Anais Endipe, 2006. p. 109-126.

COSTA SILVA, R. G. Dinâmicas territoriais em Rondônia: conflitos na produção e uso do território no período de 1970/2010. Tese (Doutorado) em Geografia, USP, São Paulo, 2010.

COSTA SILVA, R. G. Espaço, sociedade e natureza em Rondônia. Revista Geoamazônia, v. 1, p. 144-165, 2014. Disponível em: http:// dx.doi.org/10.17551/2358-1778/geoamazonia.n2v1p144-165. Acesso: 12 dez. 2020.

COSTA SILVA, R. G; CONCEIÇÃO, F. S. Agronegócio e campesinato na Amazônia brasileira: transformações geográficas em duas regiões nos estados de Rondônia e Pará. Geographia (UFF), v. 19, p. 54-72, 2017. 
Geografia, livro didático e educação: problematizações

da temática agrária no ensino fundamental

Disponível: https://periodicos.uff.br/geographia/article/view/13819. Acesso em: 10 fev. 2021.

COSTA SILVA, R.; NEVES, J. G. Território, Direitos Humanos e Educação do/no Campo na Amazônia. Rev. Educ. Pública, Cuiabá, v. 27, n. 65, p. 635-655, maio/ago. 2018.

COSTA, C. L. A Presença e ausência do debate de gênero na geografia do ensino fundamental e médio. Revista Latino-Americana de Geografia e Gênero, Ponta Grossa, v. 2, n. 2, p. 76-84, ago./dez. 2011.

FREIRE, P. Pedagogia da Autonomia: saberes necessários à prática educativa. 26. ed. Rio de Janeiro: Paz e Terra, 2002.

FREIRE, P. Pedagogia do oprimido. Rio de Janeiro: Paz e Terra, 1987.

GERHARDT, T. E.; SILVEIRA, D.T. (org.). Métodos de pesquisa. Porto Alegre: Ed. UFRGS, 2009.

IBGE. Instituto Nacional de Geografia e Estatística. Estatística de gênero. Uma análise dos resultados do Censo Demográfico de 2010. Estudos e pesquisas. ISSN 1516-3296. Disponível em: https://biblioteca.ibge.gov.br.

LIMA, L. A. P; COSTA SILVA, R. G. Cartografia das hidroestratégias na Amazônia brasileira. ACTA Geográfica, Boa Vista, v. 12, n. 28, jan./ abr. de 2018, p. 129-142. Disponível em: https://revista.ufrr.br/actageo/ article/view/4510. Acesso em: 18 abr. 2021.

NASCIMENTO SILVA, M. G. S. Reflexos das políticas públicas desenvolvidas e o empoderamento das mulheres em assentamentos rurais. In: ALMEIDA SILVA, A.; NASCIMENTO SILVA, M. G. S.; COSTA SILVA, R. G. (org.). Colonização, território e meio ambiente em Rondônia: reflexões geográficas. Curitiba: SK Editora; Porto Velho: PPGG/UNIR, 2012.

NEVES, Josélia Gomes Currículo Intercultural: processo de aplicação da Lei 11.645 /2008 nas escolas públicas da Amazônia. Revista Partes, 2013. Disponível em: www.partes.com.br/2013/05/15/curriculo-intercultural/. Acesso em: 15 jul. 2016.

PONTUSCHKA, N. N. A geografia: pesquisa e ensino. In: CARLOS, A. F. A. (Org.) Novos caminhos da geografia. São Paulo: Contexto, 1999. p. 111-142.

PRADO, Clodoaldo José Bueno do. O livro didático de geografia do $6^{\circ}$ ao $9^{\circ}$ ano do ensino fundamental: estudo da linguagem cartográfica sob o foco da formação da consciência espacial cidadã. 257f. Curitiba, 2014. 


\section{Geografias de Rondônia Território, Fronteira e Educação}

PRINTES, R. B. Presença indígena nos livros didáticos de geografia. Revista Brasileira de Educação em Geografia. Campinas, v. 4, n. 8, p. 195-220, jul./dez., 2014.

RIBEIRO, A. F. A.; COSTA SILVA, R. G.; CORREA, S. S. Geografia da soja em Rondônia: monopolização do território, regionalização e conflitos territoriais. Campo-Território, (UFU) v. 10, p. 180-201, 2015. Disponível: $\quad$ www.seer.ufu.br/index.php/campoterritorio/article/viewFile/28439/17010. Acesso em: 26 abr. 2021.

RONDÔNIA. Referencial curricular para o Estado de Rondônia Ensino Fundamental. Porto Velho: Seduc/RO, 2020.

ROSSINI, R. E. Geografia e gênero: a mulher na lavoura canavieira paulista. Tese Livre Docência. São Paulo: FFL/USP, 1988.

SACRITÁN, J. Gimeno. O currículo: uma reflexão sobre a prática. 3. ed. Porto Alegre: Artmed, 2000.

SALES, A. L. P.; VINHAL, T. P. A mediação didática da Geografia e o livro. Caderno Prudentino de Geografia, Presidente Prudente, n. 35, v. 1, p. 78-89 jan./jul. 2013. Disponível em: https://revista.fct.unesp.br/index. php/cpg/article/view/1870/2411. Acesso em: 10 jan. 2021.

SANTOS, M. A natureza do espaço: técnica e tempo, razão e emoção. São Paulo: Hucitec, 1996, 308 p.

SUAVE, M. P. Dinâmica agrária em Rondônia: proposições para o ensino de geografia nos anos finais do ensino fundamental. 2019. 283 f. Dissertação (Mestrado em Geografia) - Programa de Pós-graduação em Geografia - PPGG, Universidade Federal de Rondônia-UNIR, Porto Velho, 2019.

TAVARES, F. G. O. O ensino de geografia agrária na escola pública: currículo e sala de aula. 2016. 100f. Monografia (Trabalho de Conclusão de Graduação em Geografia) - Departamento de Geografia, Faculdade de FilosofiaLetras e Ciências Humanas, Universidade de São Paulo, São Paulo, 2016.

ZAVALA, Rafael. O papel da mulher na segurança alimentar; FAO no Brasil 14/10/2019. Organização das Nações Unidas para a Alimentação e a Agricultura - FAO. Disponível em www.fao.org/brasil/noticias/detail-events/pt/c/1238916/. Acesso em: 30 abr. 2021. 


\title{
O LIVRO DIDÁTICO DE GEOGRAFIA E O ESTUDO DAS TERRAS INDÍGENAS DIANTE DA LEI N. 11.645/2008: POSSIBILIDADES DE APRENDIZAGENS INTERCULTURAIS? ${ }^{1}$
}

\author{
Josélia Gomes Neves" \\ Ricardo Gilson da Costa Silva*** \\ Rosângela Castilho Valenciano***
}

\section{INTRODUÇÃO}

As terras indígenas constituem um tema presente em muitas pautas de discussões no Brasil. De um lado, os povos indígenas têm envidado esforços no sentido de assegurar os direitos reconhecidos na Constituição Federal para demarcação dos territórios e garantir o respeito à diversidade sociocultural indígena. Por outro lado, há setores ligados ao agronegócio que questionam as demarcações destes territórios em nome de uma proposta desenvolvimentista, com ações que têm desencadeado processos de paralisações na legislação de reconhecimento dos direitos indígenas (Costa Silva; Neves, 2018; Candido, 2020).

Nessa direção, nosso interesse foi discutir aspectos do livro didático de geografia $-4^{\circ}$ e $5^{\circ}$ anos do ensino fundamental - e suas possibilidades pedagógicas relacionadas à lei n. 11.645, de 10 de março de 2008, por meio do tema terras indígenas. De acordo com essa legislação, as instituições escolares de caráter público e privado precisam incluir na

\footnotetext{
${ }^{1}$ Publicado em: NEVES, J. G; COSTA SILVA, R. G; VAlEnCIANO, R. C. O livro didático de geografia e o estudo das terras indígenas diante da lei n. 11.645/2008: possibilidades de aprendizagens interculturais? Acervo, Rio de Janeiro, v. 34, n. 2, p. 1-16, maio/ago. 2021.

" https://orcid.org/0000-0003-2318-5397

** https://orcid.org/0000-0002-3348-9629

*** https://orcid.org/0000-0002-2434-9608
} 


\section{Geografias de Rondônia Território, Fronteira e Educação}

educação básica os conteúdos sobre o modo de ser e viver das populações afrodescendentes e indígenas. O desafio foi pensar o currículo na perspectiva da educação crítica freiriana (Freire, 1987; 1996), por meio das relações entre o ambiente escolar e as práticas sociais.

Como o livro didático de geografia tem apresentado o tema terras indígenas nos anos iniciais do ensino fundamental? Como o debate social repercute no material escolar? $\mathrm{O}$ que as crianças podem aprender a partir desses referenciais? Essas questões orientaram a elaboração das reflexões, buscando compreender como as dinâmicas interculturais tensionam o currículo escolar, sobretudo, a partir do livro didático de geografia relacionado à citada legislação e à articulação entre demandas sociais e aspectos educacionais.

O estudo se constituiu em âmbito qualitativo como uma possibilidade metodológica que "trabalha com o universo dos significados, [...] entendido aqui como parte da realidade social, pois o ser humano se distingue não só por agir, mas pensar sobre o que faz e por interpretar suas ações [...]" (Minayo, 2011, p. 21-22). A coleta de dados foi realizada no período de julho a agosto de 2020, com os dados obtidos por meio da pesquisa documental, um recurso metodológico que utiliza materiais que não passaram por processos de análise (Gil, 2008). As fontes de informações foram imagens extraídas de três livros didáticos adotados em três escolas na rede pública de educação básica, no município de Ji-Paraná, estado de Rondônia. Embora a lei n. 11.645/2008 apresente orientações para o trabalho pedagógico sobre a temática "História e Cultura Afro-Brasileira e Indígena", neste texto trataremos apenas do recorte indígena.

\section{POVOS INDÍGENAS, TERRITÓRIOS E SABER FORMAL}

Desde criança aprendemos na escola que os povos indígenas foram os primeiros habitantes no Brasil. No entanto, essa narrativa se limita a uma citação sem correspondência ou significados com as práticas sociais, uma vez que as nações indígenas vivenciam discriminações e exclusão territorial. Para discutir essas relações, sobretudo no que diz respeito à ruptura com o ideal integracionista, o Estado brasileiro estabeleceu, na Constituição Federal (Brasil, 1988), o direito à identidade indígena, com a preservação de seus modos de vida nos espaços tradicionais: 
$\mathbb{S} 1^{\circ}$ São terras tradicionalmente ocupadas pelos índios as por eles habitadas em caráter permanente, as utilizadas para suas atividades produtivas, as imprescindíveis à preservação dos recursos ambientais necessários a seu bem-estar e as necessárias a sua reprodução física e cultural, segundo seus usos, costumes e tradições [...] (Brasil, 1988, p. 1)

A tensão e a insegurança em torno das questões envolvendo as terras indígenas possivelmente são a maior preocupação dos povos originários em todos os tempos. E, apesar da lei máxima do país estabelecer o direito dos povos indígenas em permanecer nos territórios ancestrais, isso não tem evitado as múltiplas violações, impactando de formas diversas essas áreas que deveriam ser efetivamente protegidas. $\mathrm{Na}$ atualidade, há um agravamento dessa situação, explicitada no documento final do acampamento Terra Livre na edição 2020, coordenado pela Articulação dos Povos Indígenas do Brasil (APIB) e parcerias. O pensador ameríndio Ailton Krenak, uma das referências que participou das mobilizações indígenas durante a elaboração da Constituição Federal de 1988 e que permanece contribuindo para a discussão atualmente, também chamou atenção para a questão das terras indígenas no Brasil em publicação recente:

Essa tensão não é de agora, mas se agravou com as recentes mudanças políticas introduzidas na vida do povo brasileiro, que estão atingindo de forma intensa centenas de comunidades indígenas que nas últimas décadas vêm insistindo para que o governo cumpra seu dever constitucional de assegurar os direitos desses grupos nos seus locais de origem, identificados no arranjo jurídico do país como terras indígenas [...] (Krenak, 2019 , p. 20)

Em várias situações, essas infrações são decorrentes de forças econômicas poderosas, nas quais é possível incluir o próprio Estado brasileiro (Faleiros; Nascimento, 2019), materializadas em flexibilização das ações fiscalizadoras, venda ilegal de lotes de terras nos territórios indígenas (Fellet, 2021), roubo de madeira, além da paralisação dos processos de novas demarcações em tramitação, entre outras (Prado; Urquiza, 2017). Diante desse quadro, uma discussão tem sido inevitável: é possível a escola não indígena contribuir na problematização e desconstrução de preconceitos e discriminações contra os povos indígenas? 


\section{Geografias de Rondônia Território, Fronteira e Educação}

Como os temas de interesses indígenas podem ser materializados no currículo escolar? Não é possível responder integralmente essas perguntas de caráter pedagógico mais amplo neste texto, mas elas são necessárias para pensar as possibilidades formativas da escola: "Se a educação sozinha não transforma a sociedade, sem ela tampouco a sociedade muda" (Freire, 2002, p. 33). Questões como essas mobilizaram um grupo de estudiosos(as) a refletir que é possível produzir transformações sociais também a partir do ambiente escolar. Estamos nos referindo à obra inaugural proposta por Lopes da Silva e Grupioni (1995) intitulada $A$ temática indígena na escola: novos subsídios para professores de $1^{\circ} e$ $2^{\circ}$ graus. Nessa perspectiva, o tema terras indígenas foi discutido há cerca de trinta anos por meio do texto "Muita terra para pouco índio? Uma introdução (crítica) ao indigenismo e a atualização do preconceito" (Oliveira, 1995, p. 61).

Entre outras questões, o trabalho discutiu as representações depreciativas sobre os povos indígenas, ponto diretamente relacionado a uma ideia de identidade congelada no tempo. São discriminações que servem como pano de fundo para uma série de violações: "'preguiçosos', 'ladrões' e 'traiçoeiros', [...] acusações não comprovadas, mas que, de tanto repetidas, parecem juízos naturais [...] usados como evidências que permitem justificar as medidas contra os índios e até mesmo ações genocidas" (Oliveira, 1995, p. 63).

Assim, a defesa de um currículo intercultural foi fortalecida nas discussões das políticas institucionais desde os anos 2000, com debates sobre a inclusão das temáticas da sociodiversidade no espaço escolar, sobretudo pelas publicações das leis n. 10.639, de 9 de janeiro de 2003, e n. 11.645/2008. As pressões da sociedade civil por meio dos movimentos sociais provocaram um conjunto de ações públicas e institucionais significativas, culminando com a publicação da lei n. 11.645/2008:

Art. 26-A - Aos estabelecimentos de ensino fundamental e de ensino médio, públicos e privados, torna-se obrigatório o estudo da história e cultura afro-brasileira e indígena.

$\mathbb{} 1^{\circ} \mathrm{O}$ conteúdo programático a que se refere este artigo incluirá diversos aspectos da história e da cultura que caracterizam a formação da população brasileira, a partir desses dois grupos étnicos, tais como o estudo da história da África e dos africanos, a luta dos negros e dos povos indígenas no Brasil, a cultura negra e indígena brasileira e o negro e o índio na for- 
mação da sociedade nacional, resgatando as suas contribuições nas áreas social, econômica e política, pertinentes à história do Brasil.

$\mathbb{S} 2^{\circ}$ Os conteúdos referentes à história e cultura afro-brasileira e dos povos indígenas brasileiros serão ministrados no âmbito de todo o currículo escolar, em especial nas áreas de educação artística e de literatura e história brasileiras (Brasil, 2008, p. 1).

A citada legislação estabelece que o currículo da educação básica deverá abordar as culturas e histórias afro-brasileira e indígenas como importantes referências para a sociedade brasileira no decorrer de todas as disciplinas, sobretudo nas áreas de arte, história do Brasil e literatura. Essa proposição legal se constitui em um relevante instrumento de validação das diferenças socioculturais no currículo, na medida em que impulsiona ações didáticas na escola, principalmente nos materiais escolares.

A partir daí importantes entrelaçamentos são efetuados envolvendo a lei n. 11.645/2008, currículo, especificidades socioculturais na educação, políticas públicas e cidadania (Neves, 2013). E, nessa direção, o ensino da geografia pode ser uma importante contribuição para as discussões sobre as concepções equivocadas a respeito dos povos indígenas no imaginário social, desde o início da escolarização fundamental, uma vez que é necessário "buscar explicações para aquilo que, numa determinada paisagem, permaneceu ou foi transformado, isto é, os elementos do passado e do presente que nela convivem e podem ser compreendidos mediante a análise do processo de produção/organização do espaço" (Brasil, 1997, p. 74).

Nessa direção, o trabalho pedagógico nos anos iniciais do ensino fundamental exige uma atenção formativa crítica de ruptura com a geografia tradicional, que dentre outros aspectos, se caracteriza "[...] pela enumeração de dados geográficos [...] trabalha espaços fragmentados, em geral opera com questões desconexas, isolando-as no interior de si mesmas, em vez de considerá-las no contexto de um espaço geográfico complexo, que é o mundo da vida" (Callai, 2005, p. 229). Significa propor uma reflexão outra, considerando principalmente as diversas relações entre os fenômenos sociais observados. 


\title{
Geografias de Rondônia Território, Fronteira e Educação
}

\section{TERRAS INDÍGENAS E LIVROS DIDÁTICOS DE GEOGRAFIA: QUE CONCEPÇÕES NARRAM?}

\begin{abstract}
Não é apenas indígena a terra onde se encontra edificada a casa, a maloca ou a taba indígena, como não é apenas indígena a terra onde se encontra a roça do índio. Não. A posse indígena é mais ampla e terá que obedecer aos usos, costumes e tradições tribais, [...] e será de posse indígena toda a área que sirva ao índio ou ao grupo indígena para caça e pesca, para coleta de frutos naturais, como aquela utilizada com roças, roçadas, cemitérios, habitação, realização de cultos tribais, etc., hábitos que são índios e que, como tais, terão de ser conservados para preservação da subsistência do próprio grupo tribal (Brasil, 1989, p. 25).
\end{abstract}

Os primeiros estudos sobre o livro didático ganharam visibilidade na década de 1980, por meio de dois livros: Mentiras que parecem verdades (Eco; Bonazzi, 1980) e As belas mentiras (Nosella, 1978). Até então, o conteúdo veiculado nesses materiais eram considerados verdades absolutas e inquestionáveis. Esses dois estudos, ancorados nas teorias crítico-reprodutivistas (Bourdieu; Passeron, 2013) e crítica (Freire, 1987), produziram indagações aos livros didáticos, denunciando as contradições entre realidade e representação. A publicação de Eco e Bonazzi (1980) ocorreu inicialmente na Itália e depois no Brasil, já a obra de Nosella (1978) constituiu um estudo sobre a realidade do livro didático produzido no país. Ambas apresentaram discussões temáticas a partir de diferentes representações, explicitando subalternizações de classe, raça, gênero e etnia. Desde então e cada vez mais, tem se discutido os conteúdos e as imagens veiculadas nesse tipo de material e as correspondências com o mundo real.

Particularmente em relação aos estudos envolvendo geografia, povos indígenas e livro didático, há uma visível produção acadêmica a respeito, sobretudo depois da publicação da lei n. 11.645/2008, que estabeleceu a obrigatoriedade da representação originária no currículo. Destacamos um conjunto de estudos (Printes, 2014; Guites, 2019; Martins; Pureza, 2020; Cigolini; Silva, 2020) que, de forma geral, analisam conteúdos de livros didáticos, com utilização ou não de imagens, e suas relações com o campo do conhecimento geográfico. Envolvem temas referentes às identidades étnicas, produções autorais indígenas, a vida na contemporaneidade, uso de tecnologias, entre outros. Um elemento comum é que os materiais analisados são do ensino fundamental, 
anos finais. E essa é uma das diferenças centrais em relação à proposta em tela, cujo recorte acadêmico é o ensino fundamental, anos iniciais.

Assim, o propósito das reflexões se forma nessa perspectiva: como o livro didático de geografia tem apresentado o tema terras indígenas no início da escolarização fundamental? O debate social repercute no material escolar? O que as crianças podem aprender a partir desses referenciais? E como essa discussão começou?

Segundo o Estatuto do Índio, todos os territórios indígenas deveriam ter sido demarcados até o final de 1978. Como era de se prever, isto não aconteceu. O que se viu, foram constantes ameaças aos territórios indígenas, que continuavam sem a necessária proteção legal. Por isso, a nova Constituição de 1988 estabeleceu, no art. 67 das disposições transitórias que: "A União concluirá a demarcação das terras indígenas no prazo de cinco anos a partir da promulgação da Constituição". Porém, esta meta também não foi executada [...] (Lira, 2016, p. 55)

De acordo com os Parâmetros Curriculares Nacionais (PCNs) de geografia é importante compreender que a dinamicidade do processo produz modificações no espaço geográfico a partir das ações humanas. É nesse sentido que as discussões sobre as terras indígenas podem ser contextualizadas, possibilitando serem percebidas como espaços locais relevantes, pois constituem "paisagem [que] representa as heranças das sucessivas relações no tempo entre a sociedade e a natureza. [...]" (Brasil, 1997, p. 74). A percepção da localidade constitui uma oportunidade da inserção das terras indígenas nos estudos da geografia na perspectiva da lei n. 11.645/2008. E é nessa direção que analisamos quatro imagens referentes ao tema, para responder às questões orientadoras do estudo. 


\section{Geografias de Rondônia Território, Fronteira e Educação}

Figura 1 - Terras indígenas na escola. Coleção Ligamundo, $5^{\circ}$ ano.

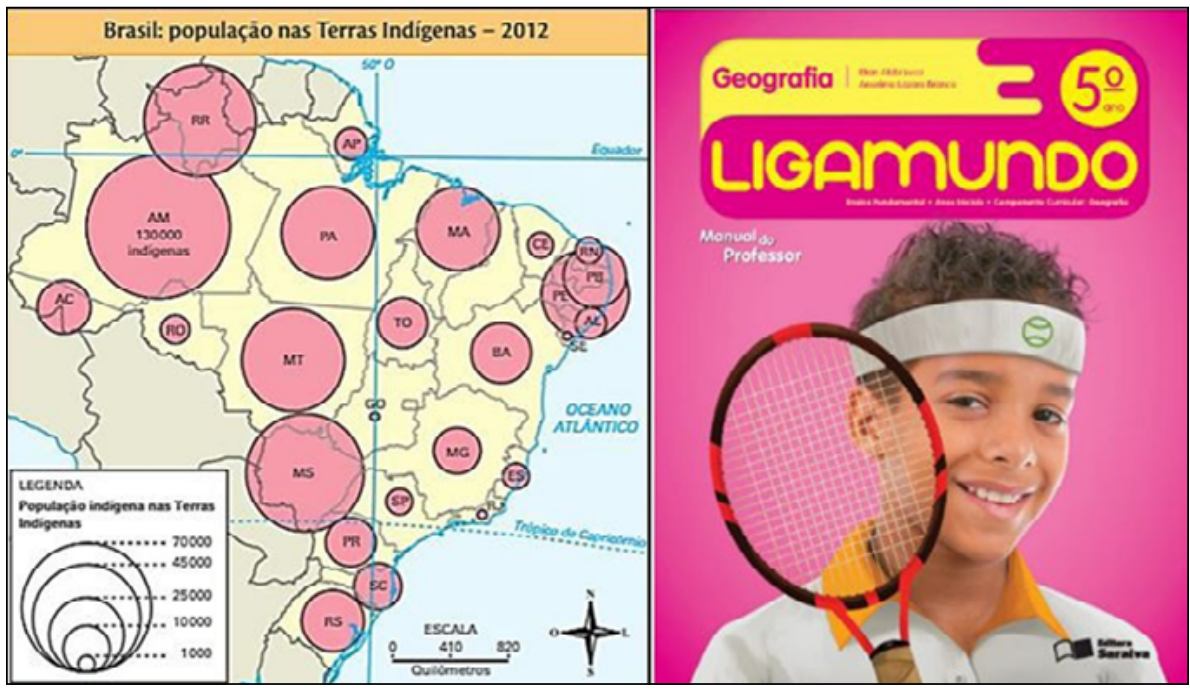

Fonte: Lucci, 2017, p. 131.

A Figura 1 corresponde a uma imagem de um livro de $5^{\circ}$ ano do ensino fundamental, cuja atividade proposta tem como título "Terras Indígenas": "Você já estudou que as terras indígenas são territórios demarcados para o usufruto dos povos indígenas. Agora, observe o mapa e descubra qual é a população das terras indígenas em cada estado brasileiro" (Lucci, 2017, p. 131). O mapa destacou os estados da federação com um círculo cor de rosa proporcional ao quantitativo de pessoas indígenas e etnias, constituindo uma novidade no livro didático. Isso porque a maioria dos materiais pedagógicos anteriores à lei n. 11.645/2008 não discutia o estudo da história e culturas indígenas no currículo escolar, limitavam-se a apresentar os povos indígenas vinculados aos referenciais do colonizador, por meio do dia 22 de abril ou do dia 19 de abril, no chamado "dia do índio". Nessas ocasiões, as imagens indígenas correspondiam a uma representação estereotipada relacionada ao contexto histórico do início da colonização europeia. (Grupioni, 1995; Lopes da Silva, 1987; Telles, 1987; Brasil, 2015). 
livro didático de geografia e o estudo das terras indígenas diante da lei n. 11.645/2008: possibilidades de aprendizagens interculturais?

Figura 2 - Terras indígenas na escola. Coleção Ligamundo, $5^{\circ}$ ano.

(1) O que são Terras Indigenas?

Terras Indigenas são áreas legalmente demarcadas pelo governo brasileiro para

usufruto dos povos indigenas.

(2) Indique os três estados que têm a maior população em Terras Indigenas e os três estados que têm a menor.

Maior população: Amazonas, Mato Grosso do Sul e Roraima. Menor: Goiás, Sergipe

e Rio de Janeiro.

(3) Em sua opinião, por que há concentração significativa de população em Terras Indigenas na região Norte do Brasil?

Porque nessa regiẫo está a Floresta Amazônica, que permite aos indigenas encontrar mais meios de sobrevivência e manutenção de seus modos de vida.

Fonte: Lucci, 2017, p. 131.

$\mathrm{Na}$ Figura 2, a atividade continua: são apresentadas três questões relacionadas ao assunto, como recurso de aprofundamento. Os estudantes, ancorados na compreensão definida na Constituição Federal, escreverão o significado das terras indígenas. $\mathrm{Na}$ segunda questão, é solicitada a indicação dos estados que apresentam a maior e menor população indígena, a partir de consulta ao mapa discutido na Figura 1. E a última pergunta exige reflexão aprofundada, pois há necessidade de produzir explicações referentes à região Norte e o quantitativo de povos indígenas. $\mathrm{Na}$ atividade em discussão, o trabalho pedagógico poderá propiciar um conjunto de aprendizagens interculturais, ${ }^{2}$ como, por exemplo, a possibilidade de perceber a presença indígena ao longo do território brasileiro, bem como de relacionar as terras indígenas como barreiras ao desmatamento, possibilitada pela questão 3. É essencial que o estudo sobre as terras indígenas considere integralmente o estabelecido na Constituição Federal, no artigo 231, em uma linguagem acessível às crianças, na perspectiva do direito e da justiça social. A discussão do

${ }^{2} \mathrm{O}$ conceito de aprendizagens interculturais, neste texto, corresponde à compreensão de um conjunto de saberes críticos, envolvendo múltiplas culturas no contexto das diferenças sociais, no âmbito da educação libertadora. Uma elaboração em curso a partir das leituras de Freire (2002) e Walsh (2009). 


\section{Geografias de Rondônia Território, Fronteira e Educação}

tema, ainda que introdutória, em turmas do $5^{\circ}$ ano do ensino fundamental contribui para conhecimentos relevantes sobre os povos indígenas e suas diversidades:

1. Reconhecer que os povos indígenas no Brasil são muitos e variados, possuem organizações sociais próprias, falam diversas línguas, têm diferentes cosmologias e visões de mundo, bem como modos de fazer, de pensar e de representar diferenciados.

2. Reconhecer que os povos indígenas têm direitos originários sobre suas terras, porque estavam aqui antes mesmo da constituição do Estado brasileiro e que desenvolvem uma relação coletiva com seus territórios e os recursos neles existentes [...]. (Brasil, 2015, p. 9)

Assim, a proposta apresentada nas Figuras 1 e 2 possibilita aos estudantes discutirem a multiplicidade de povos indígenas existentes, os modelos societários, as diferentes línguas e múltiplas compreensões de mundo, aspectos que traduzem as suas especificidades. Oferece, principalmente, a oportunidade de saber que os povos indígenas possuem direitos originários sobre os territórios, anteriores a própria criação do Estado brasileiro. Questão possível de ser ampliada com o tema do marco temporal, ${ }^{3}$ os impactos sobre os povos indígenas e seus territórios em processo de demarcação.

3 “Ação no Supremo Tribunal Federal (STF) que defende que povos indígenas só podem reivindicar terras onde já estavam no dia 5 de outubro de 1988. Naquele dia, entrou em vigor a Constituição Brasileira [...]” (Candido, 2020). 
Figura 3 - Terras Indígenas e os peixes.

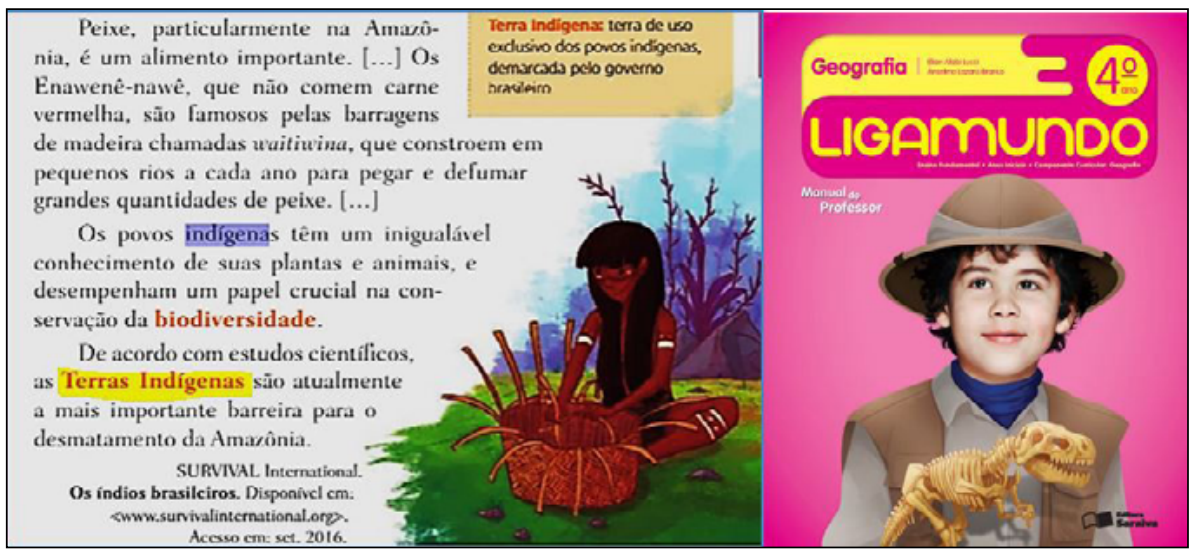

Fonte: Coleção Ligamundo, $4^{\circ}$ ano (2017, p. 29).

A atividade correspondente à Figura 3 tratou de um texto sobre os recursos alimentares no âmbito das terras indígenas, envolvendo o povo enawenê-nawê, extraído de um livro de $4^{\circ}$ ano do ensino fundamental da rede pública estadual. Informa sobre uma prática sociocultural desta etnia, referente ao consumo do peixe e às técnicas adotadas no processo de captura e conservação do pescado. Estudos apontaram que a "economia desses povos indígenas se configuram nas culturas de mandioca e de milho e na atividade pesqueira, sendo tirada do peixe a principal fonte de proteína dos enawenê-nawê" (Luiz; Costa, 2014, p. 2). O texto do livro didático destacou o papel dos povos indígenas na preservação da biodiversidade, considerando seus conhecimentos sobre plantas e animais e sua atuação como obstáculo ao avanço do desmatamento nas áreas de floresta amazônica, confirmando que "a dívida que a humanidade contraiu com o saber etnobotânico do primitivo habitante das Américas está longe de ser resgatada. As principais plantas de que se alimenta [...] foram descobertas e domesticadas pelos ameríndios" (Ribeiro, 1995, p. 199). Outra questão apresentada constitui uma repercussão de estudos, veiculados em mídias digitais, que atestam os serviços ambientais decorrentes dos territórios: "Terras indígenas funcionam como barreira ao desmatamento na Amazônia" (Terras..., 2019).

Em muitas sociedades, o ser humano adquire recursos para a sobrevivência - como alimentos, roupas, medicamentos, entre outros exclusivamente por meio da venda da força de trabalho. $\mathrm{O}$ acesso às 


\section{Geografias de Rondônia Território, Fronteira e Educação}

discussões de textos envolvendo o modo de vida dos enawenê-nawê, por exemplo, informa a existência de modos de vida diferentes de outras sociedades, caracterizados por relações outras estabelecidas com a natureza, desconstruindo a concepção corrente que todos os povos indígenas são carnívoros. Com o olhar para o ensino da geografia, será possível discutir o conceito de território indígena, analisando as semelhanças e as diferenças das práticas das sociedades indígenas e não indígenas. Assim como entre diferentes etnias, levando em conta "não considerar o território como produto acabado e permanente. Para isso, recuperar a historicidade do território é importante para a análise das transformações pela qual o mesmo passou e passa [...]" (Souza, 2012, p. 162).

O texto da Figura 3 apresentou alguns aspectos da cultura do povo indígena enawenê-nawê, que habita diferentes municípios do estado do Mato Grosso. O peixe representa mais que um alimento na vida da etnia, tem relações com a espiritualidade e a coesão social do grupo: "Quando um enawenê nasce, sendo o(a) primeiro(a) filho(a), sela a união de um homem e uma mulher no momento em que o pai reconhece a paternidade pagando peixe ao sogro. [...]" (Luiz; Costa, 2014, p. 9). Entendemos que o livro didático é um importante recurso metodológico para o ensino, porém, os conteúdos precisam ser analisados para incluírem, nas atividades propostas, o contexto local e, assim, aproximar cada vez mais os estudantes da realidade em que vivem. (Costa Silva; Suave; Neves, 2021).

A imagem da Figura 4 foi coletada em um livro do $4^{\circ}$ ano do ensino fundamental utilizado em escolas da rede pública municipal. Discute a temática terras indígenas a partir da criação do Parque Indígena do Xingu, um espaço multicultural que abriga 16 etnias indígenas. A demarcação, ocorrida em 1961, foi resultado das pressões dos movimentos indígenas e indigenistas. No entanto, é importante salientar que as respostas oficiais nem sempre corresponderam às expectativas indígenas: "Embora a concepção do parque recue a 1952, quando os irmãos Villas-Bôas apresentaram o anteprojeto ao presidente Café Filho, a sua demarcação oficial só ocorreu em 1961, [...] a homologação [...] em 1991, [...] com uma extensão bem menor (cerca de dez vezes) daquela proposta inicial [...]” (Lira, 2016, p. 59). 
Figura 4 - Terras indígenas na escola.

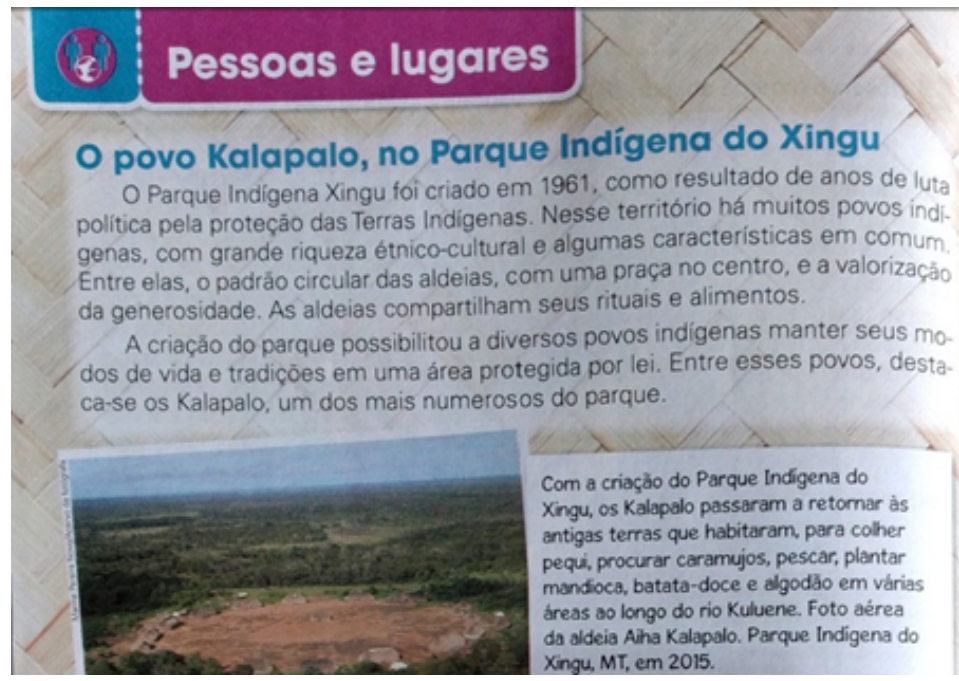

Fonte: Coleção Aprender Juntos, $4^{\circ}$ ano (2017, p. 28).

A Figura 4 possibilita observar o formato das aldeias, entre as quais a do povo kalapalo, uma das maiores no território. O espaço foi apresentado como meio de reorganização da vida indígena. A terra como local das vivências e ressignificações, nesse caso, evidenciando as práticas socioculturais alimentares. Assim, não se tratando de um simples amontoado de terras, o significado é bem mais profundo, o território como morada, fonte de sentidos e recursos propiciadores da existência, uma convergência com as finalidades atuais da geografia que tem "buscado práticas pedagógicas que permitam apresentar aos alunos os diferentes aspectos de um mesmo fenômeno [...], de modo que [...] possam construir compreensões novas e mais complexas a seu respeito" (Brasil, 1997, p. 77).

É uma ocasião propícia para aprofundar as discussões provocadas pelo livro didático, pesquisando um pouco mais sobre as etnias no Parque do Xingu, os kaiapó, kamaiurá, suiá, kuikuro, kaiabi, entre outras. Outra atividade que pode ser incluída nesse item é a exibição e posterior interpretação do audiovisual ${ }^{4}$ Xingu, o clamor da flo-

\footnotetext{
${ }^{4}$ Disponível em: www.youtube.com/watch?v=Jz-jFZnWXs0. Acesso em: 15 jul. 2020.
} 


\title{
Geografias de Rondônia Território, Fronteira e Educação
}

resta, samba enredo de 2017 com o qual a escola de samba Imperatriz Leopoldinense, do Rio de Janeiro, homenageou os povos indígenas no Brasil por meio dos povos do Xingu:

\begin{abstract}
Kararaô, kararaô, o índio luta pela sua terra; da Imperatriz vem o seu grito de guerra! Brilhou a coroa na luz do luar, nos troncos, a eternidade, a reza e a magia do pajé! $\mathrm{Na}$ aldeia com flautas e maracás, kuarup é festa, louvor em rituais [...]. Sou guerreiro imortal derradeiro, deste chão o senhor verdadeiro, semente eu sou a primeira da pura alma brasileira! Jamais se curvar, lutar e aprender. Escuta menino, Raoni ensinou. Liberdade é o nosso destino, memória sagrada, razão de viver. Andar onde ninguém andou, chegar aonde ninguém chegou. Lembrar a coragem e o amor dos irmãos e outros heróis guardiões $[\ldots] .^{5}$
\end{abstract}

O estudo do texto "O povo kalapalo no Parque Indígena do Xingu" e a interpretação do samba enredo Xingu, o clamor da floresta se constituem importantes aprendizagens interculturais. São relevantes meios para a contextualização do tema, na medida em que favorecem os conhecimentos sobre a história dos povos indígenas em diferentes temporalidades. Assim, ao apresentar o tema terras indígenas no livro didático de geografia como conteúdo curricular no ensino fundamental, as discussões se expandem para além da data comemorativa de 19 de abril. Nessa perspectiva, as reflexões sobre os territórios indígenas possibilitam aprendizagens interculturais essenciais, uma vez que: "A invenção da existência a partir dos materiais que a vida oferecia levou homens e mulheres a promover o suporte [...]. Quanto maior se foi tornando a solidariedade entre mentes e mãos, tanto mais o suporte foi virando mundo e a vida, existência. [...]" (Freire, 2002, p. 29).

Esse trabalho pedagógico atende o determinado pela lei $\mathrm{n}$. $11.645 / 2008$ e pelo parecer 14, que estabeleceram as "diretrizes operacionais referentes à aplicação da história e das culturas dos povos indígenas na educação básica”, pois “o reconhecimento do direito à diversi-

\footnotetext{
${ }^{5}$ Composição: Adriano Ganso, Aldir Senna, Jorge do Finge, Moisés Santiago. Disponível em: www.letras.mus.br/imperatriz-leopoldinense-rj/xingu-o-clamor-que-vem-da-floresta-sambaenredo-2017/. Acesso em: 15 jul. 2020.
} 
dade étnica e cultural [...] exige, por sua vez, o conhecimento, por meio de informações corretas e atualizadas, sobre os povos indígenas, [...] seus saberes e práticas [...] e suas lutas políticas. [...]” (Brasil, 2015, p. 8).

As quatro imagens analisadas sugerem que o livro didático de geografia tem discutido o tema terras indígenas como conteúdo curricular nos anos iniciais do ensino fundamental, levando em conta as orientações da lei n. 11.645/2008. A sua inserção na pauta escolar pode significar que, de algum modo, os debates realizados nas práticas sociais - desmatamento e biodiversidade, por exemplo, apontados na Figura 3, evidenciam conexões entre a educação e a sociedade. Essa forma de atividade representa uma possibilidade de atribuição de sentido para o trabalho pedagógico e, com isso, pode contribuir para a construção de importantes aprendizagens, pois "ensinar não é transferir conhecimento, mas criar as possibilidades para a sua produção ou a sua construção. [...]" (Freire, 1996, p. 12).

\section{CONSIDERAÇÕES FINAIS}

As possibilidades da escola discutir a temática indígena no currículo a partir de aproximações com os atuais modos de vida das etnias originárias mobilizou a escrita deste texto. Nessa perspectiva, a principal finalidade foi elaborar uma reflexão tendo como fonte de análise elementos do livro didático de geografia do ensino fundamental - anos iniciais - e sua relação com a lei n. $11.645 / 2008$, por meio do conteúdo terras indígenas, na visão da educação crítica freiriana.

A realização do estudo ocorreu a partir de pesquisa documental pedagógica. Uma forma de pensar, coletar e analisar materiais escolares - cadernos e livros didáticos - como fontes históricas, possibilitando enxergar e detectar os aspectos iniciais das mudanças socioculturais que ocorrem na escola e nas relações com a sociedade.

Foi possível compreender que alguns livros didáticos de geografia dos anos iniciais do ensino fundamental têm discutido a questão das terras indígenas conforme a expectativa proposta pela lei n. 11.645/2008. Trata-se de um aspecto importante, por evidenciar a inserção de temas sociais relevantes para as crianças no início da escolarização. Essas análises de materiais de $4^{\circ}$ e $5^{\circ}$ anos explicitaram que a discussão sobre o tema envolve a definição do termo, a localização e a importância desses territórios para a manutenção dos modos de vida indígenas. 


\section{Geografias de Rondônia Território, Fronteira e Educação}

A presença desse assunto na pauta escolar pode significar importantes avanços para o entendimento das relações entre educação e sociedade, na medida em que asseguram o debate social como elemento formativo da cidadania, como pode ser observado especialmente nas imagens referentes ao Xingu e aos enawenê-nawê. Além de evidenciar rupturas com a memorização, perspectiva tradicional na geografia, apontando para a necessidade de caminhos outros de compreensão.

Uma visão que, em nossa percepção, se aproxima da concepção de educação freiriana, que vê a disponibilização de conhecimentos críticos como elemento essencial para a interpretação e atuação dos sujeitos no mundo. Um arranjo que pode propiciar aprendizagens interculturais para as crianças em uma etapa inicial do ensino fundamental.

A presença do tema terras indígenas na escola, também por meio do livro didático, pode significar um importante recurso para a perspectiva curricular intercultural. Significa ainda afirmar que o assunto central das questões indígenas terá um pequeno, mas relevante, espaço no âmbito do conhecimento formal. Assim, apresenta novos aspectos e tensiona as concepções existentes sobre o território como categoria de estudo.

\section{REFERÊNCIAS}

BOURDIEU, Pierre; PASSERON, Jean-Claude. A reprodução: elementos para uma teoria do sistema de ensino. 2. ed. Petrópolis: Vozes 2013. BRASIL. Parecer CNE/CEB n. 14, de 11 de novembro de 2015. Diretrizes operacionais para a implementação da história e das culturas dos povos indígenas na educação básica, em decorrência da lei n. 11.645/2008. Disponível em: http://portal.mec. gov.br/index.php?. Acesso em: 22 abr. 2018.

BRASIL. Lei n. 11.645, de 10 de março de 2008. Inclusão no currículo oficial da rede de ensino a obrigatoriedade da temática História e Cultura Afro-Brasileira e Indígena. Disponível em: www.planalto.gov.br. Acesso em: 15 jul. 2019.

BRASIL. Parâmetros curriculares nacionais: história/geografia. Secretaria de Educação Fundamental. Brasília: MEC/SEF, 1997.

BRASIL. Constituição (1988). Constituição Federal da República Federativa do Brasil. Brasília, DF: Senado Federal, 1988. 
livro didático de geografia e o estudo das terras indígenas diante da lei n. 11.645/2008: possibilidades de aprendizagens interculturais?

BRASIL. Ministério Público Federal. Juiz federal da $7^{\mathfrak{a}}$ vara, n. 4.620/89 - PR/DF. Brasília, DF: MPF, 1989.

CANDIDO, Marcos. O que é o marco temporal e como ele impacta os povos indígenas. UOL, 2 jun. 2020. Disponível em: www.uol.com. br/ecoa/ultimas-noticias/2020/06/02/o-que-e-o-marco--temporal-e-como-ele-impacta-indigenas-brasileiros.htm?cmpid=copiaecola. Acesso em: 18 de abr. 2021.

CIGOLINI, Adilar Antonio; SILVA, Michelle Correa da. A temática indígena no ensino de geografia: problemas e caminhos. Revista Geografar, Curitiba, v. 15, n. 1, p. 82-100, jan./jun. 2020.

COSTA SILVA, R. G; SUAVE, M. P.; NEVES, J. G. Geografia, livro didático e educação: problematizações da temática agrária no Ensino Fundamental. Revista Cerrados, [S. 1.], v. 19, n. 2, p. 20-51, 2021.

COSTA SILVA, R. G; NEVES, J. G. Território, Direitos Humanos E Educação do/no campo na Amazônia. Revista de Educação Pública, v. 27, p. 635-655, 2018.

ECO, Umberto; BONAZZI, Marisa. Mentiras que parecem verdades. 5. ed. São Paulo: Summus, 1980.

FALEIROS, Gustavo; NASCIMENTO, Fábio. Sob Bolsonaro, invasões de terras indígenas superam 2018. Piauí, $1^{\circ}$ out. 2019. Disponível em: https://piaui.folha.uol.com.br/sob-bolsonaro-invasoes--de-terras-indigenas-superam-2018/. Acesso em: 18 abr. 2021.

FELLET, João. Investigação revela terras protegidas da Amazônia à venda no Facebook. BBC News Brasil, 26 fev. 2021. Disponível em: www.bbc.com/portuguese/brasil-56148670. Acesso em: 18 abr. 2021.

FREIRE, Paulo. Pedagogia da autonomia: saberes necessários à prática educativa. São Paulo: Paz e Terra, 1996.

FREIRE, Paulo. Pedagogia do oprimido. Rio de Janeiro: Paz e Terra, 1987.

GIL, A. C. Como elaborar projetos de pesquisa. 3. ed. São Paulo: Atlas, 2008.

GUITES, Airton Rosa Lucion. Geografia e livro didático: representação dos povos indígenas. 2019. Dissertação (Mestrado em Geografia) 


\section{Geografias de Rondônia Território, Fronteira e Educação}

- Programa de Pós-Graduação em Geografia, Universidade Federal de Santa Maria, Santa Maria, 2019.

GRUPIONI, Luís Donizete Benzi. Livros didáticos e fontes de informações sobre as sociedades indígenas no Brasil. In: LOPES DA SILVA, Aracy; GRUPIONI, Luís Donizete Benzi. A temática indígena na escola: novos subsídios para professores de $1^{\circ}$ e $2^{\circ}$ graus. Brasília: MEC/MARI/ Unesco, 1995. p. 481-527.

KRENAK, Ailton. Ideias para adiar o fim do mundo. São Paulo: Companhia das Letras, 2019.

LIRA, Keyte Ferreira de. Territorialidade indígena: a implantação de uma nova aldeia no Parque Indígena do Xingu (PIX)/Mato Grosso. Dissertação (Mestrado em Geografia) - Universidade Federal de Mato Grosso, Cuiabá, 2016.

LIMA, Luís Augusto Pereira; COSTA SILVA, Ricardo Gilson da. O sistema agro na apropriação espacial dos recursos hídricos em Rondônia. In: Simpósio Internacional de Geografia Agrária e Simpósio Nacional de Geografia Agrária, 8.; 9., 2017, Curitiba. Anais... Curitiba: 2017. Disponível em: https://singa2017.files.wordpress.com/2017/12/gt10_15 07224907_arquivo_sstemaagro_recursoshidricos_singa2017.pdf. Acesso em: 18 abr. 2021.

LOPES DA SILVA, Aracy (org.). A questão indígena na sala de aula: subsídios para professores de $1^{\circ}$ e $2^{\circ}$ graus. São Paulo: Brasiliense, 1987. LUCCI, Elian Alabi. Ligamundo: Geografia, $4^{\circ}$ ano. Ensino fundamental, anos iniciais. São Paulo: Saraiva, 2017.

LUIZ, André; COSTA, Gisseli Vilas Boas. Valoração cultural: os enawenenawe e o ritual yaokwa. In: Jornada Interdisciplinar Direito e Saúde, 1., 2014, Juína, MT. Anais... Juína-MT: Ajes/Faculdade de Direito e Faculdade de Enfermagem, 2014. Disponível em: www.site.ajes.edu.br/ jornada/arquivos/20140505181540.pdf. Acesso: 20 ago. 2020.

MARTINS, Alan Bizerra; PUREZA, Marcelo Gaudêncio Brito. O ensino de geografia e as relações étnico-raciais nos livros didáticos no ensino fundamental. Geografia Ensino \& Pesquisa, Santa Maria, v. 24, p. 1-31, 2020. Disponível em: https://periodicos.ufsm.br/geografia/article/ view/40314. Acesso em: 18 abr. 2021. 
MINAYO, Maria Cecília S. (org.). Pesquisa social: teoria, método e criatividade. 22. ed. Petrópolis: Vozes, 2011.

NEVES, Josélia Gomes. Currículo intercultural: processo de aplicação da lei 11.645/2008 nas escolas públicas da Amazônia. Revista Partes, São Paulo, 15 maio 2013. Disponível em: www.partes.com.br/2013/05/15/ curriculo-intercultural/. Acesso: 20 ago. 2020.

NOSELLA, Maria de Lourdes Chagas Deiró. As belas mentiras: a ideologia subjacente aos textos didáticos. São Paulo: Editora Moraes, 1979. OLIVEIRA, João Pacheco de. Muita terra para pouco índio? Uma introdução (crítica) ao indigenismo e à atualização do preconceito. In: LOPES DA SILVA, Aracy; GRUPIONI, Luís Donizete Benzi. A temática indígena na escola: novos subsídios para professores de $1^{\circ}$ e $2^{\circ}$ graus. Brasília: MEC/MARI/Unesco, 1995.

PRADO, José Henrique; URQUIZA, Antonio Hilário Aguilera. “Temos o dever sagrado de defender o que é nosso": a trajetória e a luta política de Marçal de Souza Tupã'i. MovimentAção, Dourados, v. 4, n. 6, p. 125-143, 2017. Disponível em: https://ojs. ufgd.edu.br/index.php/movimentacao/article/download/7639/5001. Acesso em: 18 abr. 2021.

PRINTES, Rafaela Biehl. Presença indígena nos livros didáticos de geografia. Revista Brasileira de Educação em Geografia, Campinas, v. 4, n. 8, p. 195-220, jul./dez. 2014.

RIBEIRO, Berta G. A contribuição dos povos indígenas à cultura brasileira. In: LOPES DA SILVA, Aracy; GRUPIONI, Luís Donizete Benzi. A temática indígena na escola: novos subsídios para professores de $1^{\circ}$ e $2^{\circ}$ graus. Brasília: MEC/MARI/Unesco, 1995.

SILVA, Leda Leonardo da. Geografia: $4^{\circ}$ ano do ensino fundamental. Coleção aprender juntos. São Paulo: Edições SM, 2017.

SOUZA, R. R. de. O conceito território no ensino da geografia: breves notas sobre abordagens negligenciadas. Geografia em questão, v. 5, n. 2, 2012. Disponível em: http://e-revista.unioeste.br/index.php/geoemquestao/article/view/4974/5233. Acesso: 20 ago. 2020.

TELLES, Norma. A questão indígena na sala de aula (resenha). Caderno de Pesquisa, São Paulo, n. 62, p. 79-80, agosto 1987. Disponível em: https://dialnet. unirioja.es/servlet/articulo? codigo=6209249. Acesso em: 21 dez. 2019. 
Geografias de Rondônia Território, Fronteira e Educação

TERRAS indígenas funcionam como barreira ao desmatamento na Amazônia. Jornal da USP, 20 dez. 2019. Disponível em: https://jornal. usp.br/ciencias/ciencias-humanas/terras-indigenas-funcionam-como-barreira-ao-desmatamento-na-amazonia/. Acesso em: 18 abr. 2021.

WALSH, Catherine. Interculturalidade crítica e pedagogia decolonial: in-surgir, re-existir e re-viver. In: CANDAU, Vera Maria (org.). Educação intercultural na América Latina: entre concepções, tensões e propostas. Rio de Janeiro: 7 Letras, 2009. 


\title{
TERRITÓRIO, CONTEXTO HISTÓRICO E EDUCAÇÃO ESCOLAR INdígena PaITer Suruí: DA LIBERdade À OFICIALIDADE
}

\author{
Márcia Helena Gomes" \\ Ricardo Gilson da Costa Silva"** \\ Josélia Gomes Neves ***
}

\section{INTRODUÇãO}

Houve um tempo que os territórios de perambulação indígenas eram livres. As disputas existiam, geralmente ocorriam entre outros povos com certa igualdade de condições (Ribeiro, 1985). Neste estudo apresentaremos uma sistematização reflexiva a respeito das relações entre território, contexto histórico e Educação Escolar Indígena a partir da trajetória histórica Paiter Suruí, habitantes da Terra Indígena Sete de Setembro, localizada no município de Cacoal-RO.

A proposta do texto é demonstrar como os diferentes eventos produzidos pela concepção de Estado-nação (definições fronteiriças, realização de edificações, exploração mineral, construção de estradas de ferro, extração do látex, instalação das linhas telegráficas e outras) impactaram os modos de vida Paiter Suruí. Diante destas ocorrências o Povo se viu obrigado a permanentes processos de territorialização.

O estudo foi desenvolvido no período de 2016 a 2017 nas Aldeias Gapgir e Lapetanha, nas escolas Sertanista José do Carmo Santana e Tancredo Neves. A metodologia adotada foi a observação participante de caráter etnográfico (André, 1985). Os dados foram possibilitados pela pesquisa documental que usa materiais "[...] que não receberam nenhum tratamento analítico. [...], fotografias, gravações, memorandos, regulamentos, ofícios, boletins, etc.”. (Gil, 2002, p. 46). E também por

"https://orcid.org/0000-0003-4342-7373

** https://orcid.org/0000-0002-3348-9629

*** https://orcid.org/0000-0003-2318-5397 


\section{Geografias de Rondônia Território, Fronteira e Educação}

meio da pesquisa narrativa que entende que, o ser humano, “[...] é um ser contador de histórias [...] a investigação de caráter qualitativo tem tido o mérito de explorar e organizar este potencial humano, produzindo conhecimento sistematizado através dele" (Cunha, 1997, p. 192).

O trabalho está estruturado em duas partes: a primeira trata de reflexões sobre território, desterritorialização e ressignificação no contexto Paiter Suruí. Buscou inventariar os diferentes momentos históricos em que a sobrevivência física e cultural foi reorganizada por meio da produção do espaço. Já a segunda, discute o Território Paiter Suruí como tema de estudo no ambiente escolar. Uma reflexão que interpela as possibilidades e limites da ação formativa na defesa e produção do território por meio do conhecimento.

\section{REFLEXÕES SOBRE TERRITÓRIO, DESTERRITORIALIZAÇÃO E RESSIGNIFICA- Ção No CONTEXto Paiter Suruí}

Os registros bibliográficos dão conta que a chegada de grupos não indígenas na região de moradia atual dos Paiter Suruí foi impulsionada por um empreendimento militar no período colonial pela Coroa Portuguesa tendo em vista finalidades protecionistas do território: “As primeiras referências da chegada de pessoas não indígenas à região onde vive o povo Paiter Suruí foram registradas no século 18, com a construção do Forte Príncipe da Beira, às margens do Rio Guaporé, no atual município de Costa Marques. [...]" (Pappiani; Lacerda, 2016, p. 241).

Para estas autoras, esta época foi marcada pela implementação de projetos de mineração no sentido de Minas Gerais até a região Centro-Oeste que por sua vez desencadearam o surgimento de ocupações como a criação de vilas e empreendimentos agrários. Posteriormente, no século XIX, possivelmente em função desta movimentação ocorreu uma série de ações pactuadas entre os países próximos em torno das definições fronteiriças. Algumas delas foram resolvidas por meio de conflitos, caso da Guerra do Paraguai, por exemplo. Mas, que discussão foi feita em relação à situação dos povos originários?

Essas fronteiras foram firmadas sem se considerarem os ecossistemas e os povos originários que já viviam nesses lugares. Rios, montanhas, florestas, aldeias, povos indígenas foram divididos entre os países como se fossem coisas, sem espírito, sem alma. Assim aconteceu com a delimitação de fronteiras entre 
Brasil e Bolívia, no que seria o Território Federal do Guaporé e que depois viria a se chamar Território e Estado de Rondônia (Pappiani; Lacerda, 2016, p. 241).

O começo do século XX também foi marcado por muitos conflitos e mortes na região de Rondônia em decorrência da expansão do capital na Amazônia. A construção da Estrada de Ferro Madeira Mamoré alterou profundamente os modos de vida da população local: "Uma ferrovia é construída em plena mata, à custa de enormes sacrifícios humanos, a Madeira-Mamoré, que ligaria concentrações de seringueiras de Porto Velho até o rio Mamoré, na fronteira da Bolívia, [...] e incorporada ao Brasil” (Ribeiro, 1995, p. 323).

Nesse mesmo período, o militar Marechal Cândido Mariano Rondon instalou as linhas telegráficas, interligando o Sul e Sudeste à região Norte do país, estratégia de controle e ocupação da Amazônia. Com isso, houve um aumento significativo do processo migratório para Rondônia, resultando em conflitos e mortes entre colonizadores e a população indígena da região (Papianni; Lacerda, 2016). Este período histórico permanece na memória indígena conforme atestam os relatos dos anciões do povo Paiter Suruí, como também dos Arara Karo:

Os Arara relatam acontecimentos relacionados ao período da implantação da rede telegráfica, como, por exemplo, a curiosa lembrança de que usavam os fios desta rede para fazer instrumentos de pesca e caça. Em certa ocasião, um indígena, ao cortar o fio da rede telegráfica provocou um estranho barulho, causando espanto a todos do grupo. Uma parte do fio atingiu a perna do indígena, machucando-o gravemente (Isidoro, 2007, p. 23).

Com a criação do Território Federal de Guaporé em 1943, esta parte da Amazônia passa por outra remodelação do espaço e da produção econômica. Em função disso, a população yara, que em Paiter significa "branco" ou não indígena, aumentou, tendo em vista o incentivo governamental para a exploração da borracha impulsionado pela Segunda Guerra Mundial (Papianni; Lacerda, 2016).

Esta atividade provocou novas disputas territoriais por causa da instalação de seringais em áreas indígenas e um dos efeitos imediatos foi o contágio de doenças desconhecidas que provocaram a fuga indígena de seus territórios tradicionais: "No Guaporé em 1954, uma epidemia 


\section{Geografias de Rondônia Território, Fronteira e Educação}

de sarampo provocou enorme mortalidade [...]. Índios arredios das tribos Tupari, Makurap, Arikapu, Jabuti e provavelmente outros atraídos por missionários católicos, abandonaram, a partir de 1952, seus antigos territórios. [...]. (Ribeiro, 1996, p. 310-311).

Após dois anos, outro desenho territorial impactou o modo de vida indígena na Amazônia: a criação do Território Federal de Rondônia em 1956, o nome proposto era para homenagear o Marechal Rondon, primeiro coordenador do Serviço de Proteção aos Índios (SPI) e responsável pela implementação das Linhas Telegráficas Cuiabá-Porto Velho. A esse respeito, as análises apontam que esta ação do Estado brasileiro foi caracterizada por vários elementos: houve uma corrida desenfreada à exploração de minérios, caso da cassiterita no município de Ariquemes e diamante em Ji-Paraná. Uma intensa movimentação que produziu ondas de explosão migratórias com alto impacto para as populações indígenas de Rondônia, potencializada pela pavimentação da BR-364 realizada pela ação do $5^{\circ}$ BEC (Batalhão de Engenharia e Construção) (Théry, 1976).

Mas, ainda na década de 1960, principalmente depois de 1964, com os militares no poder, uma nova política de ocupação da Amazônia foi instituída pelo Governo Federal. O lema "integrar para não entregar" guiava as ações de ocupação da floresta que era vista como "o deserto verde". O processo colonizatório constituiu-se em uma estratégia de ocupação de determinada área, prática adotada no Brasil há pelo menos dois séculos, com objetivos econômico-sociais e/ou políticos e militares. A esse respeito Becker (1991) entende que a colonização em grande escala, como aconteceu na Amazônia, consistiu na distribuição da terra com o controle do Estado, que estimulou, orientou e/ou preveniu os movimentos espontâneos. Argumenta, ainda, que a colonização retirou o controle da terra dos governos locais para o governo central.

Nesta direção, a colonização pode ser interpretada como um mecanismo que foi adotado para resolver problemas sociais de outras regiões. E, ao mesmo tempo, pode absorver pequenos produtores sem terra, além de povoar a fronteira em espaços estratégicos com o favorecimento de mão de obra regional: "Esse é o tempo dos conflitos e mortes entre os diversos povos indígenas que ali viviam, pois se sentiam pressionados e expulsos de seus territórios tradicionais, e passaram a se movimentar e disputar entre si o pouco de áreas livres que restavam". (Pappiani; Lacerda, 2016, p. 244). Nesta direção, a interpretação dos indígenas mais idosos do Povo Surui possibilita compreender o preço que tiveram que pagar para se defender dos ataques de grupos não indígenas: 
Para Paiter Suruí, a história está muito menos nos fatos do que num relato mítico do universo, dos espíritos, da origem do homem e de todos os seres. Mantêm, porém, a lembrança remota, transmitida de pai a filho, de um tempo em que teriam emigrado dos lados de Cuiabá para Rondônia, no século XIX, fugindo à perseguição de brancos. $\mathrm{Na}$ fuga, tiveram choques e dizimaram outros grupos indígenas, mas viveram um período de maior tranquilidade quanto à ameaça dos povoadores não índios, cujas cruéis matanças recomeçaram terríveis nos últimos 20 ou 30 anos. Mal podiam fazer e manter as roças, e apontam locais de antigas aldeias, onde mortos estão enterrados, bem além do território atual, pois viviam em correrias. Essa época era lembrada em cantos e relatos, como o do herói lendário Waiói, que já convivera com não índios no início do século e que, sem que acreditassem nele, contava aos seus a vida daquela gente que comia em horas certas arroz e feijão, tinha panelas, facões, machados e armas de fogo (Mindlin, 1985, p. 25-27).

Essas duras experiências vivenciadas com o outro, o não indígena configurou-se como uma memória da fuga para sobreviver com o "abandono" dos seus territórios e confrontos com outros povos na busca por outras produções espaciais. Mas, na visão do poder público, a atuação do Estado Nacional justificava-se pela ideologia da segurança nacional e do acesso a terras no "eldorado amazônico" (Becker et al., 1990).

Em 1967 foi criada a Fundação Nacional do Índio (Funai) em substituição ao SPI, por conta de uma série de denúncias produzidas pelo Relatório Figueredo que “[...] tinha a missão de apurar desvios e comportamentos reprováveis dos funcionários do SPI e, seguindo essa trilha, produziu um documento devastador. [...]" (Valente, 2017, p. 44). Em relação à Rondônia, os registros informam graves quadros de mortandades impulsionadas por poderosas empresas ligadas à exploração da borracha e minérios, o que provocou o Massacre do Paralelo 11: “[...]. O massacre teve início quando um grupo Cinta Larga estava construindo sua maloca e Ataíde Pereira dos Santos, pistoleiro profissional, atirou em um indígena. Em seguida, Chico Luís metralhou os índios que tentavam fugir. [...] (Brasil, 2014, p. 231).

No entanto, a criação do "novo" órgão indigenista, a Funai, seguiu de certo modo uma linha continuísta do governo militar na medida em que, se por um lado discursava a favor dos indígenas, de 


\section{Geografias de Rondônia Território, Fronteira e Educação}

outro, incentivava uma política migratória sem precedentes, o que impactava as áreas indígenas, no que se refere à subtração de suas terras. A criação do Parque Nacional do Aripuanã em 1969, ironicamente é um exemplo para a nossa afirmação, pois, ao invés de contribuir para a reorganização territorial indígena, produziu mais expropriação:

Assim, os Suruí, por exemplo, vivem encostados ao projeto de colonização Ji-Paraná, para o qual perderam, na verdade, metade de suas terras em 1976, ano em que a área indígena, de 220.000 hectares para cerca de 300 índios, foi demarcada. O Parque Indígena do Aripuanã, destinado aos índios Suruí e Cinta-Larga, havia sido criado em 1969, compreendendo uma área interditada no ano anterior. $\mathrm{O}$ Parque foi reduzido à metade em 74 e diminuído outra vez em 76, numa ilustração clara da dificuldade de defender o território indígena na região. (Mindlin, 1985, p. 23).

Além da expropriação territorial, a colonização promovida neste período da ditadura militar foi responsável pela precarização existente no fictício Parque Nacional do Aripuanã. Conforme relatos da época, constituía um espaço marcado também pela escassez de medicamentos necessários naquele momento para combater as enfermidades trazidas pelo contato:

Chiappino chegou à região habitada pelos Suruí Paiter em 1972 [...]. Na época da chegada do etnólogo, tanto os Suruí quanto os Cinta-Larga, num total que variava de 1,5 mil a 5 mil índios, haviam sido reunidos pela Funai numa região interditada que recebeu o nome de Parque Indígena do Aripuanã, uma tentativa do governo militar de repetir a experiência, considerada positiva, do Parque do Xingu. [...]. Chiappino viveu três meses entre os Suruí. [...]. Observou [...] que não havia remédios na farmácia do posto Sete de Setembro. [...]. O resultado desse abandono não demorou a aparecer. [...]. Segundo Chiappino, a doença atingiu $60 \%$ da população total, que ele calculou entre quatrocentos e quinhentos índios. (Valente, 2017, p. 81-82).

E foi também neste ano da criação do Parque Nacional do Aripuanã, em junho de 1969 que ocorreu o contato oficial do povo Paiter Suruí com 
a frente de atração comandada pelo sertanista Francisco Meireles e seu filho Apoena Meireles, "[...] quando visitaram o acampamento Sete de Setembro da Funai, fundado no dia sete de setembro de 1968 [...]. O nome Suruí da aldeia é Nambekó-dabadaqui-ba, 'O lugar onde os facões foram pendurados”” (Mindlin, 1985, p. 23). A Terra Indígena, quando demarcada, recebeu também o nome de Sete de Setembro.

No início dos anos 1970 a medida que a colonização avançava as tensões e conflitos também não paravam de surgir. Leituras deste período informaram que "[...] a Funai concedeu autorização para mais de oito empresas fazerem prospecção mineral dentro da área indígena, o que contribuiu ainda mais para as invasões". (Pappiani; Lacerda, 2016, p. 245). Possivelmente na visão indígena não era possível mais saber quem era aliado e quem era inimigo, o desfecho foi catastrófico, assim: “[...]. No dia 22 de novembro, o general Bandeira de Mello recebeu em Brasília um radiograma da $8^{a}$ Delegacia Regional informando que o Sete de Setembro havia sido atacado por cerca de duzentos índios. [...]. Apoena encontrou o corpo de Possidônio [...]". (Valente, 2017, p. 330). Possidônio Cavalcanti de Bastos era ex-jornalista do jornal O Globo, mas, neste período, atuava como sertanista na Funai em função de seu envolvimento com os povos indígenas.

A repercussão deste conflito foi grande e a imprensa brasileira noticiou aspectos desta guerra territorial que acontecia na Amazônia brasileira conforme registros do Jornal do Brasil (RJ) de 14 de dezembro de 1971. Neste sentido, os escritos de Betty Mindlin (1985) que viveu entre os Paiter Suruí logo depois do contato oficial, possibilitam o entendimento de que, desde 1971 havia comercialização ilegal de lotes pelos irmãos Melhorança, por meio da Colonizadora Itaporanga. Embora tenha sido objeto de denúncia tanto por parte de Apoena Meireles como de seu pai Francisco Meireles contra esta empresa, em função disso, ambos acabaram sendo afastados do órgão indigenista.

Nos anos seguintes, o modo de viver dos Paiter continuou a sofrer os impactos da colonização com a redução territorial. As ações governamentais implementavam programas de distribuição de terra que inevitavelmente produziam efeitos entre estes indígenas, incluindo o adoecimento provocado pelas enfermidades desconhecidas. Essa situação, a nosso ver, criava uma dependência da Funai e dos medicamentos ocidentais. Neste contexto, o surgimento dos espaços urbanos ganhava formas em territórios originários e alteravam para sempre as paisagens, outrora tão familiares aos olhos do Suruí: 


\section{Geografias de Rondônia Território, Fronteira e Educação}

Em 1973 o PIC - Programa Integrado de Colonização é instalado pelo Incra dando origem à atual cidade de Ji-Paraná. Nesse período, o povo Paiter Suruí passa a morar de forma permanente nas proximidades do posto da Funai, em razão das epidemias que dizimaram a população. [...]. O município de Cacoal é criado em 1974 em área tradicional Paiter Suruí, que vê as florestas, os babaçuais, os taquarais, áreas importantes onde buscavam materiais para necessidades básicas, serem totalmente devastadas. Nesse tempo, muitos Paiter perambulam pelas estradas e vilas pedindo alimentos e roupas aos yara ey. [...]. (Pappiani; Lacerda, 2016, p. 245).

Por certo tempo, a tensão produzida na colonização dos anos oitenta, através de mortes, envolvia os dois lados, atingia indígenas e não indígenas, era potencializada principalmente pela presença de invasores no território Paiter. Uma das respostas públicas às pressões indígenas foi o desencadeamento dos processos demarcatórios e a criação em 1977 de um novo posto na Linha 14. (Pappiani; Lacerda, 2016). Em 1983 finalmente a Terra Indígena Sete de Setembro foi homologada conforme o Decreto n. 88.867 , no entanto, os problemas de invasão ainda preocupam os Suruí.

Avaliando esta trajetória, compreendemos que situações como essas vivenciadas pelos Paiter Suruí ganham ainda mais complexidade se considerarmos a perspectiva de território que o interpreta como espaço decorrente de dialogias entre as ações naturais e sociais: "[...] onde se projetou um trabalho, seja energia e informação, e que, por consequência, revela relações marcadas pelo poder. [...] o território se apoia no espaço, mas não é o espaço. É uma produção a partir do espaço [...]" (Raffestin, 1993, p. 144).

Este entendimento é importante para a compreensão dos impactos oriundos de deslocamentos forçados em áreas indígenas, sobretudo na Amazônia e os esforços feitos na ressignificação destes locais. O trabalho acadêmico proposto se encaminha para “[...] dissecar suas tramas, revelar os nexos sociais que lhe configuram historicamente, cujo resultado deve assinalar uma contribuição teórica à ciência geográfica [...]" (Silva, 2010, p. 36).

As leituras sobre o processo de ocupação da região Amazônia evidenciam o destaque dado à borracha no $1^{\circ}$ e $2^{\circ}$ ciclo, e seus desdobramentos no que diz respeito ao investimento feito na abertura de estra- 
das que facilitaram a interiorização e fortalecimento do Estado-nação. Relatos de lideranças indígenas da região central do estado de Rondônia dão conta que durante a abertura da BR-29, atual BR-364, surgiu um “seringalista” diferente. Ele tinha máquinas que pareciam um jacaré. Esperavam que como os outros em algum momento ele se retirasse de seus territórios, mas isso nunca ocorreu. $\mathrm{O}$ "seringalista" não estava atrás de borracha, era o Estado brasileiro (Ferreira, 2018).

Outras leituras apontam que o surgimento e fortalecimento do Estado-nação representa uma "[...] entidade política, configura um novo arranjo social e geográfico" (Little, 2002, p. 4). Uma visão que interpreta as territorialidades dos povos originários como áreas deslegitimadas. Essa deslegitimação, a nosso ver decorre também da visão produzida por forças corporativas caracterizadas pelo alto investimento em variados recursos científicos e tecnológicos (Costa Silva, 2015). Um aparato que veicula uma imagem de estrutura competente na gestão da terra, caso dos sistemas de monoculturas e de agropecuárias representados pelo agronegócio no Brasil.

Uma possível contraposição neste sentido, de compreender os territórios indígenas para além de uma simples aquisição de terras, tem se apresentado por meio de um conjunto de normativas pactuadas em âmbito internacional e nacional. Estamos nos referindo à Convenção n. 169 da Organização Internacional do Trabalho (OIT), que estabeleceu os direitos dos povos indígenas sustentados por alguns princípios:

[...]. Os direitos de propriedade e posse de terras tradicionalmente ocupadas pelos povos interessados deverão ser reconhecidos. [...]. Os governos tomarão as medidas necessárias para identificar terras tradicionalmente ocupadas pelos povos interessados e garantir a efetiva proteção de seus direitos de propriedade e posse. (OIT, 2011, p. 9-10).

No Brasil, a Constituição Federal de 1988, estabeleceu uma nova pactuação entre o Estado brasileiro e os povos indígenas, uma ruptura com a mentalidade de outrora que defendia perspectivas integracionistas. O capítulo VIII e seus dois artigos, 231 e 232 reconhecem os territórios, línguas e culturas como modos de vida específicos. Inferimos que este 


\section{Geografias de Rondônia Território, Fronteira e Educação}

registro inaugura o início de uma perspectiva de Estado Plurinacional ${ }^{1}$, concepção aprofundada da democracia representativa:

São reconhecidos aos índios sua organização social, costumes, línguas, crenças e tradições, e os direitos originários sobre as terras que tradicionalmente ocupam, competindo à União demarcá-las, proteger e fazer respeitar todos os seus bens [....]. São terras tradicionalmente ocupadas pelos índios as por eles habitadas em caráter permanente, as utilizadas para suas atividades produtivas, as imprescindíveis à preservação dos recursos ambientais necessários a seu bem-estar e as necessárias a sua reprodução física e cultural, segundo seus usos, costumes e tradições. [...] As terras tradicionalmente ocupadas pelos índios destinam-se a sua posse permanente, cabendo-lhes o usufruto exclusivo das riquezas do solo, dos rios e dos lagos nelas existentes (Brasil, 1988, p. 76-77, grifo nosso).

No entanto, é possível afirmar que apesar destes documentos normativos estabelecerem os direitos territoriais aos povos indígenas, ainda existe um conjunto de barreiras decorrentes principalmente de pressões e ações econômicas que têm comprometido sua efetivação. A título de ilustração citamos a matéria "TI Uru-Eu-Wau-Wau sofre constantemente com grandes obras públicas e ações do agronegócio", produzida pelo observatório da Fiocruz por meio do Mapa de Conflitos (Fiocruz, 2021). Estas violações na visão indígena podem ser traduzidas como uma negação à vida, situação que acarreta desfechos dramáticos no interior das aldeias.

Significa afirmar que ao ser privado do direito originário à terra, a impotência perante o poder da cultura dominante permeada pela discriminação, pelo racismo e outros. Diante destas situações muitos indígenas perdem sua referência e muitas vezes entram em depressão ou até suicídios, violação que vêm desde o período colonial: “[...] com a destruição

\footnotetext{
1 "A ideia de Estado Plurinacional, que ganha força e se desenvolve no interior de movimentos indígenas e tem como base a crítica ao projeto de Estado-nação tal como foi construído no decorrer da história republicana do país, torna-se finalmente um elemento central da nova constituição política boliviana e é apresentada como uma das bases fundamentais para a criação de um novo modelo de Estado, desdobrando-se no reconhecimento de um pluralismo cultural, político, jurídico e econômico. [...]”. (Otth, 2017, p. 9).
} 
das bases da vida social indígena, [...] muitíssimos índios deitavam em suas redes e se deixavam morrer [...]. Morriam de tristeza, certos de que todo o futuro possível seria a negação mais horrível do passado, uma vida indigna de ser vivida por gente verdadeira” (Ribeiro, 1995, p. 43).

Retomando o contexto Paiter Suruí, este povo indígena vivenciou uma experiência de desterritorialização parcial uma vez que houve deslocamento de parte do território tradicional: "Os sabedores indígenas mais velhos do meu Povo contam que nós, paiter, viemos do Estado de Mato Grosso até chegar onde hoje é o estado de Rondônia. [...]". (Surui, 2015, p. 19). Este contexto levou os Paiterey a uma situação de desterritorialização ou multiterritorialidade. (Haesbaert, 2007).

Em função disso passaram a ocupar outros espaços e a desenvolver estratégias de resistências e sobrevivências. Os estudos de Mindlin (1985) apontam a luta dos Suruí Paiter pelo atual território identificado como Terra Indígena Sete de Setembro e os processos de ressignificação cultural. Assim, o território produzido traz as marcas das identidades, pois constitui espaço e tempo de perambulações, de registros históricos da memória do povo. Evidencia neste sentido, referenciais carregados de sentido como as áreas sagradas, os lugares da pesca, da caça, do plantio, da coleta, confirmando que: "Em sua maior parte a história da Amazônia se tem o meio geográfico natural, sendo modificado, ainda que em manchas, no meio técnico e técnico-científico-informacional, sendo o espaço regional um acúmulo desigual de tempos" (Silva, 2010, p. 85).

Inferimos que a relação que estabelecem com a terra não é a mesma relação observada pela cultura de origem europeia, é um vínculo que vai muito além da posse, da propriedade, constitui uma extensão da vida coletiva. As observações que temos feito em função das vivências entre os Suruí demonstram que o conjunto de atividades que desenvolvem no território imprime a identidade e o modo de ser Paiter expressos por meio de diversificadas ações: no cuidado com as aldeias, na produção das roças, na definição das áreas sagradas onde moram os espíritos de seus antepassados, na identificação dos locais de caça e pesca.

Durante estas movimentações pode ocorrer a coleta de alimentos regionais como a castanha do Brasil, o coquinho de tucumã necessário à confecção de artesanatos, o mel tão apreciado por todos. A manutenção do cultivo das ervas medicinais utilizadas nos processos de cura, a extração de frutos para o embelezamento e realização das pinturas corporais. Assim, a Terra Indígena Sete de Setembro se apresenta como um contexto de produção de sentidos e rotinas em que: "A configuração ter- 


\section{Geografias de Rondônia Território, Fronteira e Educação}

ritorial é dada pelo conjunto formado pelos sistemas naturais existentes [...] e pelos acréscimos que os homens superimpuseram a esses sistemas naturais. [...]" (Santos, 1996, p. 51).

E, no decorrer das práticas culturais coexistem as práticas ocidentais. Como já mencionamos, coletam materiais para os adornos corporais e utensílios domésticos, caso das panelas de cerâmicas. Fazem suas roças tradicionais e o excedente é comercializado para suprir as necessidades que vieram após o contato com os não indígenas. Dentre outras, há demandas por assistência à saúde, vestuário, energia elétrica, internet (em algumas comunidades), locomoção, aquisição de alimentos. Estas ocorrências atestam que a cultura indígena está intrinsecamente relacionada ao território em que habitam com a correspondente dialogia com a situação pós-contato e suas problemáticas.

\section{O território Paiter Suruí como tema de estudo no ambiente ESCOLAR}

Eu compreendo a educação indígena, como aquela que é transmitida pelos pais, avós e os parentes próximos, porque são os pais que ensinam como deve ser Paiter perante os demais da comunidade. Pois a educação está nas nossas histórias, está nas nossas festas e na nossa religiosidade; sendo que essas são transmitidas a todo o tempo e a todo instante. Educação verdadeiramente indígena é ensinar respeitar nossas florestas, porque ela é nossa “mãe". Hoje em dia está difícil, porque nós quase não praticamos nossa cultura, ela não pode ser ensinada só no papel, tem que acontecer de verdade, senão a escola não é indígena, pois não valoriza a si próprio. (2017). Jose Xibora Suruí.

As políticas públicas, até então desenvolvidas, permitem compreender que o avanço legal no âmbito da Educação Escolar Indígena representou a partir da Constituição de 1988 um importante marco no sentido de possibilitar o início de uma relação por parte do Estado brasileiro pautada no direito à diferença. O Conselho Nacional de Educação interpretando dispositivos da Lei de Diretrizes e Bases da Educação Nacional e da Constituição Federal, 1988. Publicou em 1999, por meio do Parecer n. 14 e da Resolução n. 3 a criação da categoria escola indígena nos sistemas de ensino do país, caracterizadas como específicas, diferenciadas, interculturais e multilíngues. 


\section{Território, contexto histórico e educação escolar indígena Paiter Suruí: da liberdade à oficialidade}

Mas, recentemente as Diretrizes Curriculares Nacionais para a Educação Escolar Indígena por meio do Parecer n. 13/2012 e da Resolução n. 5/2012 publicadas pelo Conselho Nacional de Educação (CNE) reiteraram os princípios da Educação Escolar Indígena diferenciada enquanto movimento de contraposição à tradição integracionista e seu viés colonial: "Nas últimas décadas as comunidades indígenas têm buscado construir projetos de educação escolar diferenciada em contraposição à tradição assimilacionista e integracionista [...], hoje tem se tornando um local de afirmação de identidades e de pertencimento étnico [...]”. (Brasil, 2012, p. 23).

Nesta direção, é possível observar aproximações entre as práticas pedagógicas produzidas nas escolas da Terra Indígena Sete de Setembro, município de Cacoal, estado de Rondônia e as Diretrizes Curriculares Nacionais para a Educação Escolar Indígena. Estas proximidades se materializam no dia a dia docente por meio da aprendizagem inicial da língua materna escrita no papel e em suportes eletrônicos. E, de igual modo ocorre a aprendizagem da língua portuguesa necessária às relações pós-contato, por meio da atuação de docentes indígenas das próprias comunidades, na articulação curricular entre os saberes ancestrais com os saberes ocidentais, por exemplo:

Observamos que a família é presente na educação das crianças e adolescentes e espera da escola uma complementação aos conhecimentos transmitidos por ela, principalmente na sustentabilidade, nas memórias dos mitos, na manutenção e na escrita da Língua Materna. Compreendemos que são situações complexas e que a escola, da forma que se encontra, não está preparada para satisfazer todas essas necessidades. No entanto, é possível, por meio de práticas político-pedagógicas, construir espaço de diálogos com a comunidade sobre esses assuntos (Zoia; Mendes, 2017, p. 410).

Concordamos que de fato há um conjunto de desafios que precisam ser enfrentados para que as escolas indígenas Paiter Suruí possam representar um espaço de aprendizagens interculturais estratégicas a partir dos interesses de seu povo, onde a centralidade do território precisa estar presente. Há necessidade de se avançar na produção de materiais didáticos específicos, de construir processos de autonomia pedagó- 


\section{Geografias de Rondônia Território, Fronteira e Educação}

gica, dentre outros, de modo a poder contribuir a qualidade de vida das comunidades indígenas na perspectiva cidadã.

Figura 1 - Escola Tancredo Neves.

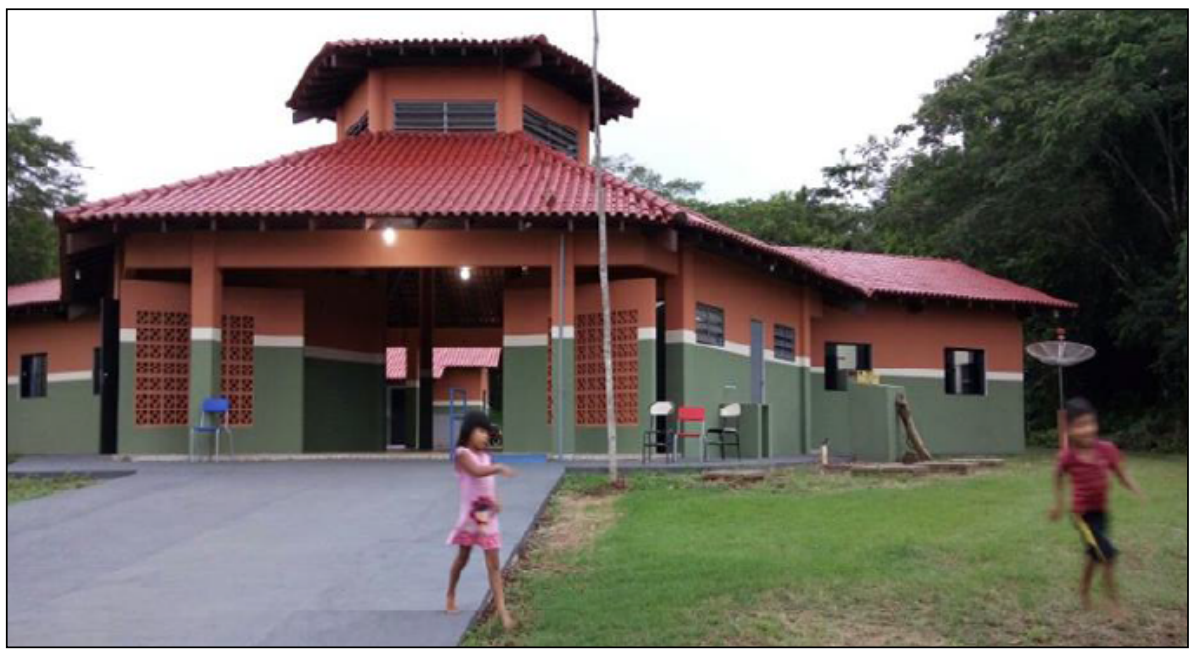

Fonte: Dados da Pesquisa.

Neste sentido, a Educação Escolar Indígena no contexto Paiter Suruí corresponde a um conjunto de 9 (nove) escolas mantidas pela Secretaria de Estado da Educação (Seduc) com a atuação de 36 (trinta e seis) docentes Paiterey e 15 (quinze) docentes não indígenas, responsáveis pelo atendimento de 347 estudantes conforme dados da matricula do Censo de 2017. Em relação à formação, parte significativa do coletivo docente indígena participou de atos para a docência. Inicialmente no Projeto Açaí - curso de magistério indígena, modalidade de nível médio conforme Decreto n. 8.516 de 15/10/1998. E, posteriormente na graduação através da Universidade Federal de Rondônia (UNIR), Campus de Ji-Paraná por meio da Licenciatura Intercultural. Em nosso entendimento, políticas públicas importantes para a atuação na Educação Escolar Indígena diferenciada e de qualidade.

A formação docente inicial constitui um elemento importante para a Educação Escolar Indígena tendo em vista as exigências postas pelas Diretrizes Curriculares Nacionais para a Educação Escolar Indígena, o estudo do território para o bem viver dos povos indígenas. Em função disso, preconiza que, "[...] territorialidade, associada à sus- 
tentabilidade socioambiental e cultural das comunidades indígenas, deve orientar todo processo educativo, definido no PPP. [...] deve ser um eixo estruturante dos projetos político-pedagógicos na Educação Básica. [...]". (Brasil, 2012, p. 23). Assim, a ação educativa a partir da escola e do currículo pode viabilizar o desenvolvimento de estratégias pedagógicas interculturais na direção do bem viver das sociedades indígenas a partir da reflexão crítica sobre o território.

Neste tópico, apresentaremos 2 (dois) diálogos com indígenas Paiter Suruí no intuito de compreender melhor o sentido da Educação Escolar Indígena e a questão do território na pauta curricular. O recurso metodológico adotado foi a Pesquisa Narrativa porque possibilita “[...] estudar como os indivíduos dão forma às suas experiências e sentido ao que antes não tinham, como constroem a consciência histórica de si e de suas aprendizagens nos territórios que habitam e são por eles habitados [...]". (Passeggi; Souza; Vicentini, 2011, p. 371). As narrativas oriundas das lembranças ou reflexões temáticas são consideradas relevantes porque contribuem para a compreensão dos entrelaçamentos entre as histórias individuais e os contextos sociais.

É perceptível notar que há uma preocupação por parte dos mais velhos com os saberes da cultura Paiter no ambiente escolar. A memória relembra o modo de viver tradicional, bem como os prejuízos trazidos pelo contato, as perdas pessoais nunca reparadas. Uma narrativa que evidencia ausências no modelo proposto de Educação escolar Indígena:

Deveria ser de minha responsabilidade ensinar nossa cultura, mas nem eu sei ao certo falar minha língua. Por isso, hoje deveríamos ensinar nossas crianças em nossa língua. É isso que estou querendo dizer. Temos que ensinar as crianças. Antigamente as pessoas faziam assim, ensinavam A fazer flecha, a fazer arco. Faziam yatir, faziam roça, a vida de Paiter era próspera. Fomos descaracterizados ao nos misturar com os yara ey. Meu pai morreu quando eu era criança, quando eu tinha doze anos, mas antes ele disse que eu deveria viver a vida com responsabilidade, respeitando o meu próximo. Segundo ele, esse é o maior princípio da vida, o respeito. Yab-a Lapixah Suruí2.

${ }^{2}$ Pertence ao clã Kaban, tem aproximadamente 55 anos vive na Aldeia Central, Linha 10, Terra Indígena Sete de Setembro. 


\section{Geografias de Rondônia Território, Fronteira e Educação}

A concepção de Educação Escolar Indígena e de desenvolvimento está amparada por lei, mas por si só não se sustentará, é imprescindível garantir sua efetividade nos territórios, pois nas narrativas dos Paiterey fica nítido que é necessário manter o diálogo baseado nos valores ancestrais e nos princípios que os mantiveram ativos na sobrevivência física e espiritual.

Embora os etnoconhecimentos ainda não contemplem plenamente algumas perspectivas é possível notar que estão presentes, ao menos pontualmente nas atividades dos estudantes. $\mathrm{O}$ registro de um trabalho escolar sugere que há conteúdos relativos ao território na escola, que o tema é discutido e representado através dos grafismos e desenhos expressos em língua materna, um dos elementos fortes da identidade dos Paiterey. Talvez estas iniciativas sistematizadas possam oferecer pistas para um conjunto de atividades sistematizadas sobre o valor da terra.

Figura 1 - Cartaz escolar.

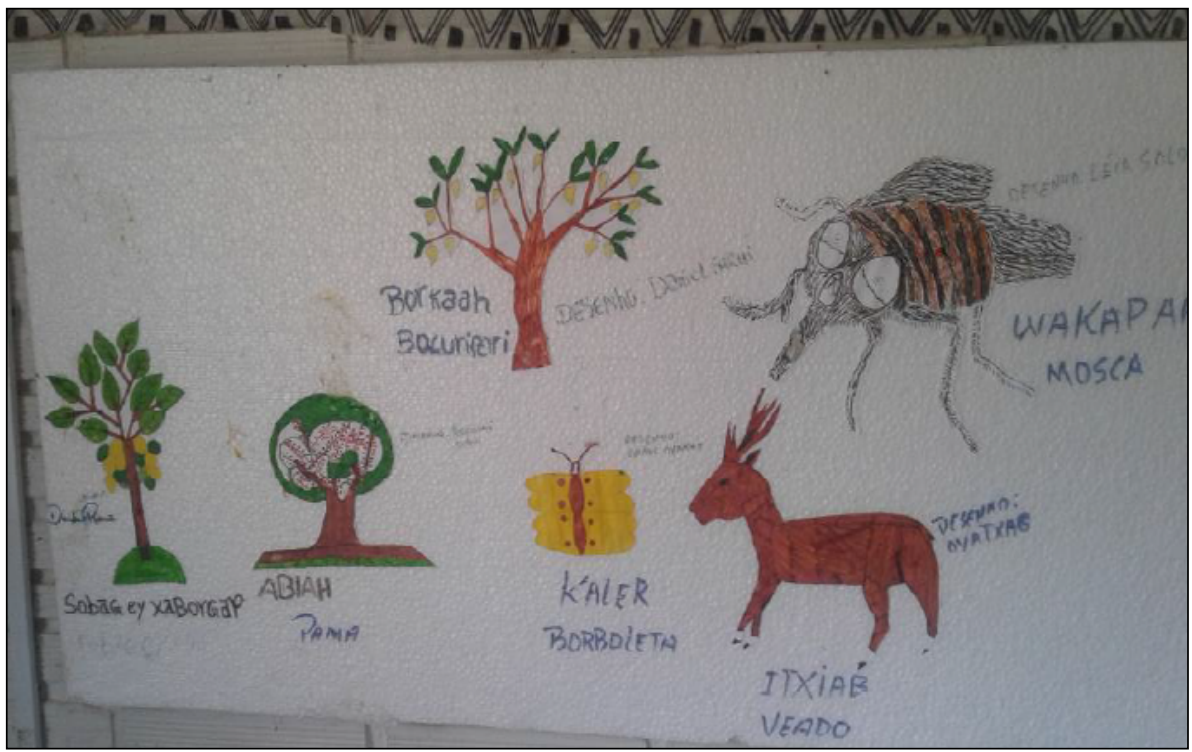

Fonte: Dados da Pesquisa.

Em relação às políticas específicas de educação indígena, no âmbito dos territórios, teremos algum sucesso se tivermos a participação, dos líderes e dos mais velhos, no fortalecimento da política interna 
sobre o que é o desenvolvimento sustentável, para proteger o que vem no presente e garantia de um o futuro melhor para nosso povo, conforme a afirmação do professor José Xibora Suruí (2017), durante entrevista na Aldeia Lapetanha:

[...] Sou professor e tenho orgulho de trabalhar sobre a defesa do nosso território, cada pedaço dessa floresta tem uma história importante, cada lugar aconteceu alguma coisa boa ou ruim, para nosso povo, então ele faz parte de nós e nós estamos vivos, enquanto ele existir tem receio que podemos perder essa riqueza, porque tem parente que não está sabendo o valor dele e está destruindo nossas riquezas. Quero um território vivo e forte, para que nossas histórias continuem sendo presentes e futura geração. Jose Xibora Suruí.

Esta afirmação demonstra que os professores estão assumindo seu papel e tendo consciência de que é necessário manter o diálogo com os ensinamentos dos sábios, principalmente em relação aos etnoconhecimentos e os valores imateriais. Segundo Zoia (2009), o professor indígena desempenha um papel fundamental na comunidade, pois é ele o responsável pela formação dos seus parentes não apenas na formação das crianças, mas também na socialização dos conhecimentos para toda a aldeia.

As reflexões apresentadas neste estudo permitem afirmar que a territorialidade Paiter Suruí passou por drásticas reconfigurações com redução do espaço de viver. No entanto, a nosso ver, o assédio dos invasores continua e na atualidade a estratégia de poder utilizada é o capital. Neste contexto, é perceptível que aqueles que se sentem mais vulneráveis podem cair em armadilhas ilusórias de que estão ganhando algo, situação produzida pela inércia do poder público e mediante ineficácia da Política de Gestão Ambiental em Terras Indígenas (Brasil, 2012). Uma situação em que há necessidade de avaliação e reflexão sobre as possibilidades de pensar em proteção de patrimônio para as futuras gerações.

Desse modo é necessário que esses conhecimentos sejam acrescidos das novas concepções educacionais para os enfrentamentos com a realidade política externa e demais situações onde o povo se relaciona. Assim, afirmamos que o projeto de educação escolar indígena constitui um desafio para os Paiterey, o que exige produção de consensos, escuta de seus líderes e dialogia com a contemporaneidade na busca de uma educação de qualidade e com sentidos para o povo e suas urgências. 


\section{Geografias de Rondônia Território, Fronteira e Educação}

\section{CONSIDERAÇÕES FINAIS}

Os povos indígenas reorganizam seus espaços a partir dos elementos de suas culturas, mas é evidente que sofrem pressões do capital sobre seus territórios e seus modelos de gestão. Essa perspectiva orientou a elaboração do referido texto, de sistematizar uma reflexão a respeito das relações entre território, contexto histórico e Educação Escolar Indígena a partir da trajetória Paiter Suruí.

Trata de um recorte extraído da dissertação de mestrado intitulada Tensões no território Paiter Suruí: os modelos de gestão na Terra Indígena Sete de Setembro e as repercussões na escola defendida em março de 2018 na Universidade Federal de Rondônia.

A sistematização histórica iniciada no século XIX quando o território Paiter era livre e concluída no século XX com a demarcação oficial em 1983 se caracterizou por permanentes processos de lutas, territorialização e ressignificação cultural. Mas, é um tema que não encontrou ainda seu lugar na escola.

A Educação Escolar Indígena caminha a passos lentos, mas mesmo assim se faz necessária, pois pode contribuir de forma efetiva para a manutenção e a preservação dos recursos naturais da Terra Indígena, mas para que isso aconteça é necessário que cada vez mais, seja capaz de atender as necessidades dos indígenas, e que a formação dos jovens sejam baseadas no fortalecimento cultural e na análise crítica da sociedade onde inevitavelmente estão envolvidos para que possam fazer escolhas que realmente contribuam para sua sobrevivência física e cultural.

Neste sentido, ela precisa ter como base a própria tradição, os conhecimentos dos mais velhos, principalmente quanto aos processos de contínuas territorializações. Assim, o desafio, é o de contribuir para uma escola que seja crítica, que consiga elaborar seus currículos com os conteúdos multidisciplinares em várias temáticas: língua materna, territorialidade, e que sejam ferramentas importantes para o mecanismo de proteção desses espaços. Que esses novos conceitos e valores agregados aos modelos de projetos educacionais, sejam um elo com os saberes ancestrais que os mantiveram presentes até os dias atuais e as complexas demandas contemporâneas. 
Território, contexto histórico e educação escolar indígena

Paiter Suruí: da liberdade à oficialidade

\section{REFERÊNCIAS}

ANDRÉ, Marli Eliza Dalmazo Afonso de. Etnografia da prática escolar. Campinas: Papirus, 1995.

BECKER, Berta K.; Miranda, Mariana; Machado, Lia O. Fronteira Amazônica: questões sobre a gestão do território. UNB, 1990.

BECKER, Berta K. Amazônia. São Paulo: Ática, 1991.

BRASIL. Constituição Federal da República Federativa do Brasil. Brasília: Senado Federal, 1988.

BRASIL. Resolução n. 005, de 22 de junho de 2012. Define Diretrizes Curriculares Nacionais para a Educação Escolar Indígena na Educação Básica. Disponível em: www.educação. s.gov. BR/dados/dp cga diretrizes indigenas.pdf. Acesso em: 25 jul. 2015.

BRASIL. Relatório da Comissão Nacional da Verdade, v. 2, 402 p. Brasília: CNV, 2014.

CUNHA, Maria Isabel da. Conta-me agora! As narrativas como alternativas pedagógicas na pesquisa e no ensino. Rev. Fac. Educ. vol. 23 n. 1-2 São Paulo jan./dec. 1997.

COSTA SILVA, Ricardo Gilson. Amazônia globalizada: da fronteira agrícola ao território do agronegócio - o exemplo de Rondônia. Confins (Paris), v. 23, p. 1-30, 2015.

FERREIRA, Eduardo Belze. Da Vila de Rondônia a Ji-Paraná - historiografias pedagógicas, saber local e interculturalidade no Ensino Fundamental I. Orientadora: Josélia Gomes Neves. 2018. 65f. Trabalho de Conclusão de Curso (TCC). Curso de Pedagogia. Universidade Federal de Rondônia. Campus de Ji-Paraná, Ji-Paraná-RO, 2018.

FIOCRUZ. Mapa de conflitos, injustiça ambiental e saúde no Brasil. Disponível em: http://mapadeconflitos.ensp.fiocruz.br/conflito/ro-terra-indigena-uru-eu-wau-wau-sofre-invasoes-desde-1980/ Acesso em: 5 nov. 2021.

GIL, Antônio Carlos. Como elaborar projetos de pesquisa. 6. ed. São Paulo: Atlas, 2018.

HAESBAERT, Rogério. Território e multiterritorialidade: um debate. Geographia, ano IX, n. 17, 2007.

ISIDORO, E. A. Situação sociolingüística do povo Arara: uma história de luta e resistência. Goiânia. 2006. 138f. Dissertação (Mestrado) Universidade Federal de Goiás, Goiânia, 2006. 


\section{Geografias de Rondônia Território, Fronteira e Educação}

LITTLE, Paul E. Territórios sociais e povos tradicionais no Brasil: por uma antropologia da territorialidade. Brasília. 2002.

MINDLIN, Betty. Nós paiter. Os suruí de Rondônia. Petrópolis: Vozes, 1985.

OIT. Convenção n. 169 sobre povos indígenas e tribais [...]. Organização Internacional do Trabalho (OIT). Brasilia, 2011.

OTTH, Ernesto de Oliveira. O conceito de Estado Plurinacional na Bolívia: origens e desenvolvimento de um novo modelo de estado. 94f. Orientador: Prof. Dr. Raúl Burgos. Trabalho Conclusão do Curso (TCC). Bacharelado em Ciências Sociais do Centro de Filosofia e Ciências Humanas. Universidade Federal de Santa Catarina, Florianópolis, 2017. PAPPIANI, A; LACERDA, I. (org.). Histórias do começo e do fim do mundo - o contato do povo Paiter Suruí. São Paulo: Ikore, 2016.

PASSEGGI, Maria da Conceição; SOUZA, Elizeu Clementino de; VICENTINI, Paula Perin. Entre a vida e a formação: pesquisa (auto) biográfica, docência e profissionalização. Educação em Revista. Belo Horizonte, v. 27, n. 1, p. 369-386, abr. 2011.

RAFFESTIN, Claude. Por uma geografia do poder. São Paulo: ática, 1993.

RIBEIRO, Darcy. O povo brasileiro: a formação e o sentido do Brasil. São Paulo: Companhia das letras, 1995.

RIBEIRO, Darcy. Os índios e a civilização. Petrópolis: Vozes, 1996.

SANTOS, Milton. A natureza do espaço - técnica e tempo. Razão e emoção. São Paulo: Hucitec, 1996.

SILVA, Ricardo Gilson da Costa. Dinâmicas territoriais em Rondônia: conflitos na produção e uso do território no período de 1970/2010. 222f. Tese (Doutorado em Geografia Humana - USP), São Paulo, 2010.

SURUI, Joaton. Metar Et Ah: uma proposta de educação escolar indígena diferenciada para o Povo Surui Paiter de Rondônia. 2015. 67f. Trabalho de Conclusão de Curso (Monografia). Universidade Federal de Rondônia. Ji-Paraná-RO, 2015.

THÉRY, H. Rondônia: mutations d'un territoire fédéral en amazonie brésilienne. 233 p. (Tese de Doutorado). Paris, Université Paris I, 1976.

VALENTE, Rubens. Os fuzis e as flechas: história de sangue e resistência indígena na ditadura. São Paulo: Companhia das Letras, 2017.

ZOIA, Alceu; MENDES, Matilde. Protagonismo Paiter Suruí: práticas político-pedagógicas e suas relações com os etnoconhecimentos. Revista de Educação Pública, [S.l.], v. 26, n. 62/1, p. 405-419, maio 2017. 


\section{2}

\section{RESISTÊNCIA E MEMÓRIA COLETIVA NO ASSENTAMENTO Madre Cristina em AriQuemes - Rondônia}

Jéssica Ferreira Costa"

\section{INTRODUÇÃO}

A memória coletiva de um grupo social constrói a sua historicidade, impulsiona o agir, pensar e sentir das percepções, pois a memória possui uma função em que ao capturar imagens do passado, o mundo vivido e percebido, coloca o ser humano no centro da criação de culturas, de tradições, de costumes, de hábitos e de continuidade na ação social (Bosi, 1995). As lembranças que flutuaram nas ondas, ora calma, ora turbulenta do tempo, comunicam e compartilham experiências que fortalecem a vivência contemporânea, uma vez que o tempo e a lembrança ensinam.

uma memória coletiva se desenvolve a partir de laços de convivência familiares, escolares, profissionais. Ela entretém a memória de seus membros, que acrescenta, unifica, diferencia, corrige e passa a limpo. Vivendo no interior de um grupo, sofre as vicissitudes da evolução de seus membros e depende de sua interação (Bosi, 1995, p. 408-411).

Nesta visão entendemos que a memória coletiva pode ser compreendida como resultado de vivências ou de relações entre um grupo social, etnia, nação, ou ainda pessoas que partilham certas coisas em comum. Dentre elas, destaca-se o território, espaço geográfico, cultura, língua, modos de vida e, assim por diante. Deste modo, o intrigante questionamento sobre o que um grupo social faz com o seu passado pode nos impulsionar, enquanto pesquisadores e pesquisadoras, a aven-

"https://orcid.org/0000-0001-6059-2456 


\section{Geografias de Rondônia Território, Fronteira e Educação}

tura de buscar a memória de um grupo de pessoas que em coletividade lutou pela reforma agrária, somando à luta contra o latifúndio suas histórias e formas de resistências na terra/território em que vivem. A memória coletiva é um elemento essencial ou fundamental para firmar a identidade camponesa, através de símbolos e representações, como modo de expressar uma continuidade na resistência por modos de convívio, interação, significação do campo e na tomada de decisão da produção alternativa de alimentos.

Este texto busca compreender a memória coletiva e a identidade impressa na trajetória de ocupação camponesa no assentamento Madre Cristina, localizado no município de Ariquemes (Rondônia), e de como essa estratégia de resistência fortalece os sujeitos para continuarem permanecendo na terra/território. Esse assentamento rural está localizado em Ariquemes, distante a $202 \mathrm{~km}$ da capital rondoniense, Porto Velho.

O processo de luta e resistência destacado por meio da memória dos camponeses e camponesas, revela o modo de interação cotidiana entre os sujeitos sociais e o processo de ocupação e permanência das famílias na terra/território. Evidentemente, a terra representa para a classe social do campesinato, local onde vive e de reprodução sociocultural. Enquanto por território compreende-se os processos de reivindicações identitárias e de direitos culturalmente diferenciados para a luta por permanência, sendo considerado os aspectos singulares de identidades, símbolos, modo de viver e produzir e de pertencimento.

A categoria de território no campesinato pode ser descrita como formas de estratégias de defesa, a partir das lutas reivindicatórias camponesas de identidade, culturas e valor simbólico sobre a terra (Guedes, 2016), para Almeida (2007, p. 159) "Identidades étnicas e culturais são armas que muitos grupos minoritários podem utilizar para se defenderem contra grupos mais fortes".

Para o Movimento dos Trabalhadores Rurais Sem Terra, o território é um pilar fundamental, e diz respeito ao modo de produzir, de viver que se tornam críticas vivas para o modo de desenvolvimento predatório, sendo, portanto, uma forma de projeto político. Little (2002, p. 4), define o território como "um produto histórico de processos sociais e políticos" e que os povos tradicionais possuem a magia de produzir "vínculos afetivos que mantém com se território específico, a história de sua ocupação guardada na memória coletiva, o uso social que dá ao território e às formas de defesa dele". Essa "cosmografia" (Little, 2001), leva ao debate a necessidade de uma reforma agrária que vai além os 


\section{Resistência e memória coletiva no Assentamento Madre Cristina em Ariquemes - Rondônia}

problemas fundiários, e de distribuição de terras, mas que se pense também sobre as identidades, valores, significados e pertencimento.

\section{Procedimentos metodológicos}

A metodologia sendo considerada como a trilha que guia o pesquisador ou a pesquisadora em seu processo de construção do conhecimento científico, o trabalho rigoroso da escolha das técnicas e dos instrumentos, que vão tomando forma desde a primeira inquietação a cerca de um problema, são fundamentais para o sucesso científico.

Portanto, o método é como um organismo que necessita ser compreendido dentro do processo científico, aliado a ele, "Esse procedimento precisa ainda referir-se a um fundamento epistemológico que sustenta e justifica a própria metodologia praticada" (Severino, 2007, p. 100). Assim, entendemos que para produzir ciência, a escolha de método e metodologia têm sua grande relevância, visto que não será possível a produção do conhecimento científico sem um método e uma metodologia bem definida.

Diante das inúmeras complexidades apontadas no decorrer da ciência, especificamente na ciência geográfica, o enlace de um único paradigma apresentado pelo positivismo já não dá mais conta dos fenômenos apresentados nas relações entre sujeito-objeto. Hoje, com o avanço da ciência, felizmente, é possível dialogar com a ciência a partir de uma pluralidade epistemológica, ou seja, as áreas de conhecimentos se conversam entre si, no objetivo de trazer sempre um melhor entendimento no desenvolvimento da pesquisa que se objetiva realizar. Há certos questionamentos e reflexões que alargam a ciência (Severino, 2007).

A pluralidade epistemológica vem surgindo em contraposição do paradigma clássico, a utopia da ciência como processo de conhecimento que se refaz em busca de saberes práticos, com tolerância, pluralidade de metodologia, respeitando o conhecimento local, dialogando com todas as formas de conhecimentos já produzidas.

A proposta metodológica desenvolvida neste trabalho é qualitativa por expressar a necessidade de aproximação com o campo ou a comunidade a ser investigada. A "abordagem qualitativa aprofunda-se no mundo dos significados das ações e relações humanas, um lado não perceptível e não captável em equações, médias e estatísticas" (Minayo, 2002, p. 22). Desta maneira, a partir dela será possível apreendermos essas instâncias de inter-relação entre os sujeitos sociais de um mesmo 


\section{Geografias de Rondônia Território, Fronteira e Educação}

lugar e como se apropriam do lugar onde se desenvolvam suas atividades cotidianas e os significados atribuídos à terra, bem como o valor da constituição da memória para o grupo social em questão.

O conjunto de técnicas empregadas para a presente pesquisa foi a coleta de dados a partir de entrevistas. Nesta ótica, é importante trazer as contribuições do Delgado (2003) sobre a história, narrando os acontecimentos; diz ele:

tempos diversos são identificados pelos elementos substantivos que os fizeram diferentes entre si. A busca do significado de um tempo tem na memória e na própria História suportes básicos. Reconhecer o substrato de um tempo é encontrar valores, culturas, modos de vida, representações, enfim um gama de elementos que, em sua pluralidade, constituem a vida das comunidades humanas (Delgado, 2003, p. 13).

Assim, compreendemos que tempo e espaço transformam os elementos vivenciados pelos sujeitos, e a história permite compreender essas alterações, as opiniões diversas, e as interpretações dos fenômenos postos atuais na vida cotidiana desses sujeitos, transformados ao longo da temporalidade.

A análise de documentos, posto que, como define Cellard (2008), é um eficiente meio de segurar registros importantes, pois a memória, muitas vezes pode trair a história no que se define em datas e detalhes. Assim, a análise de documentos aqui empregados são os relatórios descritos ou narrados pelos camponeses durante a ocupação do território do assentamento.

Outra ocorrência para a construção desse trabalho foi a revisão de literatura referente ao conceito de memória coletiva, buscando o referencial nos clássicos como Maurice Halbwachs em La mémoire collective (memória coletiva) (1956), Ecléa Bosi em Memória e sociedade: lembranças de velhos (1994).

No Assentamento de Reforma Agrária Madre Cristina, em Ariquemes, vivem aproximadamente 80 famílias, e destas em torno de 40 participaram do processo de ocupação ocorrido em 24 de julho de 1998. As outras famílias adquiriram os lotes por meio de compra. Para obter os dados, um total de 15 moradores foram entrevistados, contabi- 


\section{Resistência e memória coletiva no Assentamento Madre Cristina em Ariquemes - Rondônia}

lizando separadamente os cônjuges, posto que as perguntas foram direcionadas individualmente.

No processo de coleta das entrevistas, organizamos a separação dos entrevistados em dois grupos de acordo com a faixa etária destes, pois corresponderia com a idade em que vivenciaram o processo de ocupação do território. Assim, o primeiro grupo se concentra os entrevistados com a idade atual de 30 a 40 anos, e que durante a ocupação eram crianças ou adolescentes e que foram trazidos por seus pais. $\mathrm{O}$ segundo grupo é composto por camponeses/as com a idade atual de 50 a 60 anos, que ocuparam o território junto com os esposos/as no ano de 1998, já na idade adulta. Assim, além da relação conjugal há também as relações de mãe e filhas/os. Pais e filhos que participaram do processo de ocupação e que residem no assentamento em seus lotes já divididos, após a transformação do acampamento em assentamento de reforma agrária.

O questionário para a presente pesquisa foi de teor semiestruturada, contendo uma ordem de perguntas preestabelecidas, e a abertura de certas perguntas inseridas de acordo com as repostas adquiridas pelo entrevistado/a, sendo fundamental usufruir dessa certa liberdade adquirida proveniente do questionário semiestruturado (Santos, 2000).

\section{MEMÓRIA SOCIAL, COLETIVA E RESISTÊNCIA POPULAR}

Guardar memória é resgatar quem somos nós. Nas nossas memórias está presente o nosso passado ou quem éramos. Diversos acontecimentos nos marcam ao longo das nossas vidas, por tanto, fazem parte do nosso ser enquanto pessoas capazes de relacionar o nosso passado com nosso presente e projetando para o nosso futuro.

A memória imprime na consciência a resistência contra as vastas explorações que atravessam corpos. É pensar para além da exploração, deslocando-se para a resistência que nos impulsiona para a liberdade. Krenak (1992) indaga: como fazer história sem memória? Como pode haver vivências ativas sem guardar quadros sociais que nos forjaram? Halbwachs (1990), por sua vez, ensina que para uma memória é preciso um "local" para as lembranças surgirem e isso se aplica nos quadros sociais reais, sendo referência na reconstrução da memória coletiva. E ao ocupar uma fazenda improdutiva, se resgata os dessabores da desigualdade capitalista, calcada no agronegócio que expande fronteiras e marginaliza pobres, negros, mulheres e indígenas. 


\section{Geografias de Rondônia Território, Fronteira e Educação}

Quando se evoca uma lembrança ela vem acompanhada da família, da religião, dos amigos, da natureza, provando como Halbwachs (1990) que uma memória é construída enquanto tecemos nossas relações e afetos, posto que a memória acompanhe a vivência em grupo, em comunidade, ou seja, é algo coletivo. Neste viés verifica-se que

cada memória individual é um ponto de vista sobre a memória coletiva, que este ponto de vista muda conforme o lugar que ali eu ocupo, e que este lugar mesmo muda segundo as relações que mantenho com outros meios. Não é de se admirar que, do instrumento comum, nem todos aproveitam do mesmo modo. Todavia quando tentamos explicar essa diversidade, voltamos sempre a uma cominação de influências que são, todas, de natureza social (Halbwachs, 1990, p. 51).

Portanto, mesmo que a interpretação possa ser individual, dentro do todo, da coletividade, ela expõe uma identidade cultural, do próprio grupo no seu contexto social, pois a lembrança é evocada quando se está inserido em uma sociedade, logo ela é sempre construída em grupo, pois não se constrói memória sozinha ou isoladamente. As memórias nos ensinam, nos lembram de muitas coisas do passado e nos orientam no presente.

Nelas, podemos evocar os erros cometidos de outrora e mudar os rumos fatalmente errôneos para o melhor. Krenak (1992) evoca a importância da memória para fortalecer o espírito, para aprender a sonhar com um mundo de harmonia entre homens e a natureza, e assim reconectar o elo perdido com a memória da criação do mundo. Aqui podemos entender a memória como caminho para a solução de certos problemas que vivem a humanidade na atualidade ao fazer referência a uma determinada ou ainda pode nos servir como guia na escuridão para o reencontro a paz perdida, a harmonia entre os indivíduos ou/e com a própria natureza.

Quando se aponta que as memórias ensinam, é na perspectiva de um esforço coletivo por serem forjadas em grupo social, dialogando sobre as construções do conhecimento, apreendemos de Santos (1940) que os saberes, os conhecimentos decorrem da experiência social, e que na variabilidade de relações sociais, tem-se diferentes epistemologias 


\section{Resistência e memória coletiva no Assentamento Madre Cristina em Ariquemes - Rondônia}

construídas entre os sujeitos e destes com a natureza, inseridos em uma comum-unidade (comunidade).

Portanto, embora a memória possa sofrer novas transformações ao longo do tempo, elas têm o poder de despertar significados que compõem todo o processo de construção de particularidades típicas de determinado grupo social, povos ou etnias, no nosso caso específico, trata-se do grupo social do assentamento Madre Cristina e suas narrativas que permitem perceber ressignificados sociais e representatividade na luta pela reforma agrária e justiça social.

O grupo é o suporte da memória se nos identificarmos com ele e fazemos nosso seu passado. Nesta visão, vejamos o que nos diz Bosi (1994) ao falar sobre que as lembranças grupais,

se apoiam umas nas outras formando um sistema que subsiste enquanto puder sobreviver a memória grupal. Se por acaso esquecemos, não basta que os outros testemunhem o que vivemos. É preciso mais: é preciso estar sempre confrontando, comunicando e recebendo impressões para que nossas lembranças ganhem consistência (Bosi, 1994, p. 414).

As lembranças da comunidade ou dos povos ficam mais vivas quando esses indivíduos lutam juntos para que suas memórias guardem sempre seu devido valor de luta e resistência. Os anseios individuais e familiares terminaram de ser tecidos nos grupos que se organiza no movimento social do Movimento dos Trabalhadores e Trabalhadoras Sem-Terra (MST), e remanejam-se transformando o sonho de acesso à terra, em um sonho coletivo. Bosi (1994, p. 413) revela ainda que,

Nossos deslocamentos alteram esse ponto de vista: pertencer a novos grupos nos faz evocar lembranças significativas para este presente e sob a luz explicativa que convém à ação atual. Para localizar uma lembrança não basta um fio de Ariadne; é preciso desenrolar fios de meadas diversas, pois ela é o ponto de encontro de vários caminhos, é um ponto complexo de convergência dos muitos planos do nosso passado. 


\section{Geografias de Rondônia Território, Fronteira e Educação}

No caso das narrativas dos assentados, dos processos e embates, revelam que o grupo social se reconhece pela sua trajetória passada, através das suas vivências construídas no dia a dia, em luta e em sintonia para a conquista da terra e permanência nela. É uma luta por dignidade, por direito que todo ser humano tem para permanecer no seu lugar de origem. O lugar de origem de um povo vale muito por aqueles indivíduos que por muito tempo partilham este espaço. O lugar representa muito mais do que uma pessoa de longe poderia ter imaginado. Nossas raízes dizem muito quando pensa estudar a vida de um povo começando por sua memória, sua visão cosmológica e a sua compreensão da existência. No próximo capítulo ouviremos a voz dos sujeitos participantes desta referente pesquisa e nossa análise feita a seu respeito.

É importante lembrar para a preservação das identidades dos nossos entrevistados e entrevistadas os nomes aqui citados são fictícios. $\mathrm{O}$ que deixa as pessoas como mais vontade e tranquilidade de falar.

\section{As narrativas dos Camponeses do Assentamento de Reforma AGRÁRIa Madre Cristina}

Sons de passos numa trilha composta por cascalhos, capim e barro. Um estreito e verdejante carreador, cheio de sinuosas curvas no território do assentamento Madre Cristina. Um riozinho cortava o lote ao meio, e um tronco de árvore improvisado com um arame para garantir que os transeuntes mais desastrados possam se equilibrar, permitia a travessia de uma margem a outra do rio.

De repente, uma casa de madeira sem habitação, mas, a sua esquerda, uma majestosa rosa vermelha que acariciava a madeira da modesta casa, e indicava que uma nobre alma havia, carinhosamente, fixada a bela flor, revelando que àquele chão é importante para alguém, para uma família. Humanos são capazes de revelar amor por meio de seus plantios, e a terra retribui dando deliciosas hortaliças, frutos ou acariciando as vistas com a beleza das flores. O símbolo que essa rosa exprime, de agradecimento com a terra que acolhe, e de alegria pela conquista da reforma agrária, se multiplica em cada lote, em cada residência, fixado na horta, na roça, na árvore, e nos olhares que faíscam diante da lembrança do dia da ocupação.

Reconstruir essas lembranças, a partir das narrativas, é reconstruir o contexto social da época de 1998, e seguir as linhas dos anos. Deste modo, é possível identificar, a partir do relato de um casal de 


\section{Resistência e memória coletiva no Assentamento Madre Cristina em Ariquemes - Rondônia}

moradores do Assentamento Madre Cristina, o que fortalece o reconhecimento social com aquele espaço:

ficamos sete anos acampados, não tinha nada era só na lona e palha, fazia a parede de broto de babaçu, e lona, era bem feito. Tem madeira roliça para a estrutura ficar em pé. Chegou a 47 famílias, um pouco foi desistindo, e aí ficaram 35 famílias... Eu sinto realizada, porque foi uma luta bastante grande. $\mathrm{Na}$ época igual eu falei eu nem queria vim mais porque é ele (meu marido) que tinha o sonho, porque para mim era mais dificultoso. No começo saia discussão, fofoca, no começo foi difícil, sair da casa para um barraco, mas como lá a gente fazia trabalho de pastoral na cidade, a gente veio para cá, depois do cansaço de ficar na lona, e a gente conseguiu esse local, de ficar com a mina, com a mata, que saiu no sorteio para gente. Aí ficou bem melhor (Entrevista dada por Carla, maio, 2021).

Nas narrativas expostas pelos camponeses entrevistados, percebeu-se que toda a trajetória do dia da ocupação até o momento em que estavam sendo questionados sobre suas memórias, comporta todo um significativo social do território; cada experiência é carregada de ensinamento, de dor, de alívio e de esperança, e tal relato se assemelha com as discussões de Bosi (1994), ao demonstrar que,

Quando a sociedade esvazia seu tempo de experiências significativas, empurrando-o para a margem, a lembrança de tempos melhores se converte em sucedâneo da vida. E a vida atual só parece significar se ela recolher de outra época o alento. O vínculo com outra época, a consciência de ter suportado, compreendido muita coisa, traz para o ancião alegria e uma ocasião de mostrar sua competência. Sua vida ganha uma finalidade se encontrar ouvidos atentos, ressonância (p. 82).

Incertezas e inseguranças, sonhos e esperanças, acompanharam cerca de 70 famílias organizadas no Movimento de Trabalhadores Rurais Sem Terra - MST, na madrugada do dia 24 de julho de 1998, 


\section{Geografias de Rondônia Território, Fronteira e Educação}

quando deram início ao processo de ocupação da Fazenda Tupi I e II. Requeria-se que a improdutiva fazenda fosse objeto de reforma agrária, por meio do Plano Nacional de Reforma Agrária - PNRF. As famílias eram da região de Ariquemes e Jaru, geralmente das periferias das cidades ou filhos e filhas de pequenos produtores e sitiantes, mas com o sonho de conquista da terra e nela produzir, sonho que os conduziu a uma luta que perdurou por 16 anos. Nesse dificultoso processo, várias famílias desistiram.

Evidenciando as emoções recordadas pela memória construída nesse processo, e que eram diferentes para as mulheres e para os homens, vejamos nos recortes das entrevistas, as divergências de sentimentos experimentados pelos assentados na madrugada de 28 de julho de 1988 , dia em que ocorreu a ocupação coletiva do território para que fosse feita a reforma agrária neste lugar:

Muito entusiasmo. Porque a decisão foi minha mesma, né? Fui convidado, mas a decisão foi minha e da minha família (Entrevista dada por Sebastião, maio de 2021).

A memória do Sr. Sebastião sobre a empolgação experimentada durante a ocupação do espaço geográfico do atual assentamento de reforma agrária Madre Cristina, revela-nos a conexão entre espaço e emoção, e que memória, emoção, imaginação tem uma dimensão espacial, dialogadas dentro da Geografia das Emoções porque reporta o sujeito para outro espaço-tempo, encarnado na sua experiência cotidiana, no seu hoje, e que desperta novos significados para o território (Silva, 2018). Essa riqueza de subjetividades do ser humano embeleza a sua vivência.

O Sr. Sebastião, trêmulo de empolgação pela perspectiva de alcançar, pelas vias da reforma agrária, uma terra que fosse sua, produzir e sustentar a sua família, tem enlaces em sua vivência contemporânea.

Outros sentimentos experimentados trazem também a ideia de incertezas e dos perigos nos percalços dessa luta, legítima e importante, que é tornar uma terra improdutiva e da União em terra produtiva e repartida para a reforma agrária, sentimento evidenciado na entrevistada Clarice: 


\section{Resistência e memória coletiva no Assentamento Madre Cristina em Ariquemes - Rondônia}

no início eu senti medo porque a gente ouvia falar que enfrentar a terra dos outros da morte, né? Os Pistoleiros da Fazenda eles matam, que sempre a gente vai ocupar é a fazenda... aí eu tinha medo era disso. Mas, aí o povo da igreja católica falou para mim assim: "Não precisa ter medo não, Dona Maria, que isso aí não dá não. E a gente tem que enfrentar com coragem e firmeza porque senão, não vai" (Entrevista dada por Clarice, maio de 2021).

Alegria, dor, medo, decepção, são elementos que constituem o espaço vivenciado (Silva; Gil Filho, 2020). As emoções são parte intrínsecas do ser humano, que os acompanha fornecendo significados aos espaços, lugares, tempos, relações, ou seja, desde a subjetividade à materialidade. Assim, as emoções, enquanto subjetividades humanas são importantes nas vivências cotidianas, pois contribuem para a significação do espaço, do lugar e das relações humanas (Silva, 2018).

Outro camponês, morador do assentamento, ao observar sua trajetória desde a ocupação, sendo um dos pioneiros na luta pelo território, afirma que:

sinto orgulho. Sou o que sou porque eu estou aqui. Não consigo me imaginar o que eu seria se não tivesse obtido esse pedaço de chão. E, me afirmo como camponês, como Sem-Terra, por causa do movimento... sou Sem-Terra, sim senhor e com muito orgulho! E eu quero acreditar que a minha relação com essa terra é uma relação boa. Não uso produtos químicos de espécie nenhuma, tudo o que tem aqui é a gosto de Deus, não tenho influência de aderir a tudo o que é para acelerar a plantação (Entrevista dada por Elier, maio de 2021).

A atividade humana de "pensar as emoções é compreendê-las como parte da totalidade da experiência individual e coletiva do ser humano" (Silva; Gil Filho, 2020, p. 166), portanto, os processos da memória, aliada às emoções, tema central na Geografia da Emoção, reflete a teia de significados conferidos ao espaço, ao território, assim, a subjetividade constrói a objetividade (o significado).

O reconhecimento de pertencimento enquanto camponês, inserido dentro de um movimento social que luta pela terra, como o 


\section{Geografias de Rondônia Território, Fronteira e Educação}

Movimento dos Trabalhadores Rurais Sem-Terra, identificado na fala do Sr. Elier ao reiterar firmemente "sou Sem-Terra sim, senhor", parte para as reflexões da construção do nós, da coletividade, posto que há o eu, o outro e o lugar, assim as emoções não são partes isoladas, e as memórias sempre se vinculam com outras pessoas e lugares de vivência, posto que são construções plurais e o "eu" necessita do "outro" (pessoas e lugares) para serem solidificadas, transcendendo a individualidade.

Diante da memória de uma camponesa, que vivenciou sua adolescência, passou pela vida adulta, casou e teve um filho, dentro desse processo de acampamento para assentamento de trabalhadores rurais, ela enfatiza uma de suas mais fortes lembranças:

eu lembro das coisas que a gente ia às manifestações, gostava de ir. As pessoas eram mais reunidas naquele tempo... era mais companheirismo (Entrevista dada por Marta, maio de 2021).

E, na reconstrução de pequenos fatos memoriais dos camponeses e camponesas, os saudosismos pelos tempos de acampamento, embora diante de todas as intempéries e dificuldades, deixam firmes na memória desse grupo, a união que vigorou em tempos tão incisivos.

Durante o acampamento as famílias resistiam em coletividade, unidas, elas realizavam trabalhos por meio de diárias para sitiantes vizinhos, organizavam-se para arrumar os barracos de lona, a limpeza do acampamento, e, quando necessário, para vigiar, quando se sentiam ameaçados no território,

o povo se organizava. Quem saia e quem ficava. Quem cuidava das crianças e depois reversava e todo mundo saia, trazia dinheiro para comprar o que precisava e isso eu achava bem interessante na época. Tinha as reuniões para discutir as coisas. Os homens ficavam com uma mina, e as mulheres com outra. O povo que tá de fora acha assim: "já pensou! isso aí é uma bagunça! Esses homens e mulheres juntos... isso não deve dar certo". Mas não, era bem dividido e organizado (Entrevista dada por Carla, maio de 2021). 


\section{Resistência e memória coletiva no Assentamento Madre Cristina em Ariquemes - Rondônia}

Embora toda a trajetória tenha durado 16 anos desde a ocupação até a entrega do documento nas mãos dos assentados, que ocorreu em 2014, devido à morosidade do Instituto Nacional de Colonização e Reforma Agrária - Incra, quando questionado se houve embates violentos, respondiam-se, que:

era calmo aqui, não tinha violência na negociação, era de boa, esse fazendeiro era de boa a negociação, tinha a burocracia, tinha gente que trabalhava para ele, dava carona para os acampados. Ele era o laranja, na era o dono, o dono era do rio de janeiro (Entrevista dada por Josias, maio de 2021).

Assim, no final do ano de 2006, foi decidido pela desapropriação da fazenda Tupi I-A e II, mediante o pagamento da Dívida Pública no valor total de $R \$ 1.464 .622,38$, com resgate em 15 anos e ficou acertado que o assentamento Madre Cristina teria 35 famílias, reserva legal em Bloco, e que do total de 25 hectares cada família teria em média 40\% para uso, sendo a reserva não demarcada em parcelas. Em 2007 foi emitido o Contrato de Concessão de Uso - CCU, que só foi entregue as famílias a partir de 2014, muitos já vencidos, e 2008 também iniciada a liberação das primeiras parcelas do Crédito Instalação, para que as famílias pudessem comprar ferramentas para iniciar a produção nos respectivos lotes.

Houve a demora, por parte do Incra, em "cortar" os lotes. As famílias cansadas de esperarem, decidiram, em acordo com o órgão, pagar para que fosse feito o projeto e, posteriormente, a topografia dos lotes. As famílias, assim que terminaram os encaminhamentos das distribuições dos lotes, iniciaram os trabalhos com plantações, cavando poços, construindo casas, e demais estruturas necessárias. A vontade de ver os lotes produzindo, represadas por tanto tempo agora se tornava realidade. Hoje as relações com os lotes são ainda mais poderosas, pois a relação com a terra se estende para um sentimento:

eu sinto amor por ela, pela minha terra, é a minha felicidade. Foram 12 anos que morei debaixo da lona preta, com sol e chuva e sereno. E, nesses 12 anos foi bom demais, porque meus companheiros de luta tudo gente boa, eu amo todos eles, graças a Deus, não tenho inimizade com 


\section{Geografias de Rondônia Território, Fronteira e Educação}

nenhum. Foi difícil acostumar com o lote, quando deixamos o acampamento, porque eu deixei minhas companheiras tudo para trás, e aqui moro com a minha família e graças a Deus por não morar sozinha, mas eu sinto falta das minhas companheiras de luta... tinha com quem a gente conversar, de tarde, sentar naquelas sombras afora, nos terreiros do acampamento e tomar um chimarrão, tomar um cafezinho, era gostoso demais, tá filha. eu sinto falta ainda e alembro muito do meu acampamento (Lia, maio de 2021).

O Assentamento Madre Cristina foi tomando forma, mas já havia laços firmados desde o acampamento, mesmo com as dificuldades, os laços fortaleciam. Algumas pessoas por motivo de localidade trocaram os lotes entre si na formação do assentamento, para ficarem mais próximas de suas famílias de origem, conforme a fala da camponesa Marta:

quando dividiram os lotes eu já era casada e tive um filho, casei no acampamento, meu marido morava na cidade, né? Aí ele veio acampar e aí eu já estava acampada com a minha mãe, aí ele acampou e a gente começou a namorar e casemos. $\mathrm{Na}$ distribuição de lotes a gente escolheu a segunda Agrovila para poder ficar mais perto da minha mãe, né? (Entrevista dada por Marta, maio de 2021).

As memórias individuais acontecem pelo entrelaçamento das relações sociais, pois as lembranças são construídas em sintonia à natureza e pessoas, na memória não se está sozinho jamais. Para que haja experiência é preciso criar laços de convivência, a divisão dos lotes era também realizada de acordo com as aproximações afetivas, amizades e principalmente familiares. Assim, as pessoas que compõem o grupo social vão unindo as memórias, afetos, signos e emoções,

não basta reconstituir pedaço a pedaço a imagem de um acontecimento passado para obter uma lembrança. É preciso que esta reconstrução funcione a partir de dados ou de noções comuns que estejam em nosso espírito e também no dos outros, porque elas estão sempre pas- 


\section{Resistência e memória coletiva no Assentamento Madre Cristina em Ariquemes - Rondônia}

sando destes para aqueles e vice e versa, o que será possível somente se tiverem feito parte e continuarem fazendo parte de uma mesma sociedade, de um mesmo grupo (Halbwachs, 2003, p. 39).

Nota-se a territorialidade como essencial no desenvolvimento de seus cotidianos, pois nas territorialidades firmam-se os sentimentos de pertencimento com o território, e de sua constituição enquanto camponeses e camponesas. Sebastião, nas suas falas, nos diz:

$\mathrm{Eu}$ sou agricultor, né? Porque eu nasci na roça, apesar que eu saí um pouco fora que eu tenho outra forma de produção além da agricultura. Às vezes eu estou indo aí trabalhando as pessoas querem assinar minha carteira aí fala profissão aí eu agricultor aí a pessoa não você não pode ser agricultor aí eu dou risada e falo não eu sou eu tenho terra moro lá me considero agricultor com muita alegria (Sebastião, maio de 2021).

Sebastião, por meio de sua conversa, mostra a alegria de ser agricultor. Se sente bem ao identificar-se como pessoa que trabalha na roça. Quando a pessoa se identifica com o território carrega consigo todo um sentimento de pertença.

As entrevistas recolhidas no campo são para nós, pesquisadores e pesquisadoras, realidades que às vezes coincidem com as nossas, numa vez que nós também sentimos nossos pertencimentos e raízes fincadas em nossa territorialidade.

\section{CONSIDERAÇÕES FINAIS}

O trajeto percorrido nesse texto sintoniza-se com uma interpretação dos fatos históricos, e dos elementos que trazem em sua estrutura o significado de campesinato e de terra para essa população. As narrativas dos assentados e assentadas no Madre Cristina, em Ariquemes, Rondônia, subsidia importantes elementos sobre possíveis ressignificação da terra e seu uso presentes nessa comunidade, observadas na memória social e coletiva dos indivíduos entrevistados. 


\section{Geografias de Rondônia Território, Fronteira e Educação}

A terra em suas mãos adquire um valor simbólico, carrega um significado de vida, de trabalho e de sustento. A realidade social é feita pela identidade enquanto camponeses e camponesas, que reconhecem a si próprios e toda a comunidade enquanto sujeitos protagonistas de uma história de ocupação e resistência no campo.

O trabalho aqui composto afirma a relevância das memórias coletivas e do processo de relembrar a trajetória compostas na linha temporal iniciada em 1998 até os dias atuais, evidenciando a partir das narrativas o que os compõem enquanto camponeses e camponesas o valor social da terra. A memória construída em coletividade com as nuances das vivências grupais, relaciona-se também, afetivamente, entre os sujeitos. Essas memórias cumprem, então, uma função social com o grupo, pois são pertencentes dessa comunidade, transformada sempre em uma memória ativa, pois, o recordar revigora o que foi traçado de luta, a memória dá vida ao grupo.

As narrativas dos assentados e assentadas trazem elementos que reconstrói a memória perpassada por todo o grupo, contribuindo para que identifiquem o sentimento de pertencimento com a terra, de se reconhecerem enquanto sujeitos sociais e comunitários, conforme o mesmo anseio e sentimentos de significado da terra e do valor que tem o conceito de camponês, camponesa para essa comunidade.

\section{REFERÊNCIAS}

ALMEIDA, M. Narrativas agrárias e a morte do campesinato. Ruris Revista do Centro de Estudos Rurais, Campinas, v. 1, n. 2, p. 157-186, set. 2007. Disponível em: www.ifch.unicamp.br/ojs/index.php/ruris/article/view/656. Acesso em: 14 dez. 2021.

BOSI, E. Memória e sociedade: lembranças de velhos. 3. ed. São Paulo: Cia das Letras, 1994.

CELLARD, A. A análise documental. In: POUPART, J. et al. (Orgs.). A pesquisa qualitativa: enfoques epistemológicos e metodológicos. Petrópolis: Vozes, 2008.

FERNANDES, A. M. O Paradigma Clássico versus o surgimento de um novo paradigma da Ciência e da tecnologia e Suas Relações com o Homem, a Natureza, a História e a Cultura. In: Cadernos de Sociologia, Programa de Pós-Graduação em Sociologia, v. 4, p. 51-84, número especial, Porto Alegre. 1993. 


\section{Resistência e memória coletiva no Assentamento Madre Cristina em Ariquemes - Rondônia}

GUEDES, A. D. Lutas por terra e território, desterritorialização e território como forma social. Rev. Bras. Estud. Urbanos Reg., Recife, v. 18, n. 1, p. 23-39, jan./abr. 2016. Disponível em: https://rbeur.anpur.org.br/ rbeur/article/view/5102. Acesso: 14 dez. 2021.

GIL FILHO, S. F; SILVA, M. A. S. Sobre o conceito de espaço vivenciado: refletindo as espacialidades a partir das experiências emocionais. Revista Geograficidade, v. 10, n. especial, 2020. ISSN 2238-0205.

LITTLE, P. Territórios sociais e povos tradicionais no Brasil: por uma antropologia da territorialidade. Brasília: UnB, 2002. (Antropologia, 322).

LITTLE, P. Rio Maracá e o Delta do Rio Amazonas: entre o isolamento e a globalização. Ethos, Brasília, v. 1, n. 1, p. 63-81, 2000.

MARRADI, A. Método como arte. Papers: Revista de Sociología, Barcelona, vol. 67, p. 107-127, 2002.

HALBWACHS, M. A memória coletiva. São Paulo: Vértice, 2003.

SANTOS, I. E. Textos selecionados de métodos e técnicas da pesquisa científica. 2. ed. Rio de Janeiro: Impetus, 2000.

SEVERINO, A. J. A metodologia do trabalho científico. 23 ed. ver. e atual. São Paulo: Cortez, 2007.

SILVA. Marcia Alves Soares da. Sobre emoções e lugares: contribuições da Geografia das Emoções para um debate interdisciplinar. RBSE Revista Brasileira de Sociologia da Emoção, v. 17, n. 50, p. 69-84, agosto de 2018 ISSN 1676-8965.

KRENAK, Ailton. Antes, o mundo não existia. In: NOVAES, Adauto (org.). Tempo e história. São Paulo: Companhia das Letras, 1992. 


\section{SÚMULA CURRICULAR}

\section{Afonso Maria das Chagas}

Professor do Departamento de Ciências Sociais da Universidade Federal de Rondônia (UNIR), Porto Velho. Doutor em Ciência Política pela Universidade Federal do Rio Grande do Sul (UFRGS). Coordena, como pesquisador docente, o Grupo de Estudo e Pesquisa Jurídica (Gepejur/ CNPq); membro do Instituto "Territorialidades e Justiça” (Interjus); e atua como membro da Equipe Nacional de Formação da Comissão Pastoral da Terra (CPT). E-mail: afonso.chagas@unir.br

\section{Amanda Michalski}

Professora de geografia da Rede Estadual de Ensino (Seduc/RO). Graduada em Geografia (UNIR), mestranda no Programa de Pósgraduação em Geografia (PPGG/UNIR), pesquisadora do Grupo de Pesquisa em Gestão do Território e Geografia Agrária da Amazônia (GTGA/UNIR), Bolsista Capes. Assessora da Comissão Pastoral da Terra Rondônia (CPT/RO). Pesquisadora vinculada ao Grupo de Pesquisa GEPE-Front - UNIR. Membro do Grupo de Pesquisa Terrima-UNIR. E-mail: michalski03geo@gmail.com

\section{Carlos Alberto de Almeida Ricarte}

Professor de geografia da Rede Estadual e Municipal de Ensino de Rondônia. Graduado em Geografia pela Universidade Estadual da Paraíba (UEPB). Mestre pelo Programa de Pós-graduação em Geografia pela Universidade Federal de Rondônia (PPGG/UNIR). Membro do Grupo de Pesquisa em Gestão do Território e Geografia Agrária da Amazônia (GTGA/UNIR/CNPq). E-mail: carlosgeopb@gmail.com 


\section{Súmula Curricular}

\section{Denes Luis Reis Pedrosa}

Geógrafo, pelo Programa de Pós-graduação em Geografia pela Universidade Federal de Rondônia (PPGG/UNIR). Tem experiência na área de Geociências, com ênfase em Sistemas de Informação Geográfica. Atualmente é Analista de geoprocessamento e georreferenciamento no Projeto de Regularização Fundiária do Estado de Rondônia, parceria entre Incra/RO e Seagri/RO. E-mail: denesluisp@gmail.com

\section{Jéssica Ferreira Costa}

Assistente Social, mestranda no Programa de Pós-Graduação em Geografia - PPGG/UNIR. Membro do Grupo de Pesquisa em Gestão do Território e Geografia Agrária da Amazônia - GTGA/UNIR. E-mail: jessicateologia@hotmail.com

\section{Josélia Gomes Neves}

Doutora em Educação Escolar pela Universidade Estadual Paulista (Unesp/Araraquara). Professora do Departamento de Educação Intercultural (Deinter/UNIR) e do Professora do Programa de PósGraduação em Educação Escolar Mestrado e Doutorado Profissional PPGEE da Universidade Federal de Rondônia (UNIR). Coordenadora do Grupo de Pesquisa em Educação na Amazônia (GPEA). E-mail: joseliagomesneves@gmail.com

\section{Juander Antonio de Oliveira Souza}

Professor do Departamento de Engenharia de Produção da Universidade Federal de Rondônia (UNIR). Doutor em Geografia pelo Programa de Pós-Graduação em Geografia da Fundação Universidade Federal de Rondônia (PPGG/UNIR). Membro do Grupo de Pesquisa em Gestão do Território e Geografia Agrária da Amazônia (GTGA/UNIR/CNPq). E-mail: juander@unir.br

\section{Lucas Ramos de Matos}

Gestor Ambiental pelo Instituto Federal de Rondônia (IFRO). Mestre em Geografia pelo Programa de Pós-Graduação Mestrado e Doutorado em Geografia da Universidade Federal de Rondônia (PPGG/UNIR). 


\section{Geografias de Rondônia Território, Fronteira e Educação}

Membro do Grupo de Pesquisa em Gestão do Território e Geografia Agrária da Amazônia (GTGA/UNIR/CNPq). E-mail: lucas_matos.com@ hotmail.com

\section{Luciano Ítalo Tavares de Souza}

Graduando em Geografia pela Universidade Federal de Rondônia (UNIR). Bolsista PIBIC/CNPq. Membro do Membro do Grupo de Pesquisa em Gestão do Território e Geografia Agrária da Amazônia (GTGA/UNIR/ CNPq). E-mail: lucianoits22@gmail.com

\section{Luís Augusto Pereira Lima}

Professor de Geografia da Rede Pública de Ensino do Estado de Amazonas (Seduc/AM) e Prefeitura Municipal de Manaus (Semed/Manaus). Graduado em Geografia (UEA), Mestre em Cartografia Social e Política da Amazônia (UEMA), Doutor em Geografia pela Universidade Federal de Rondônia (PPGG/UNIR). Membro do Grupo de Pesquisa em Gestão do Território e Geografia Agrária da Amazônia (GTGA/UNIR) e do Projeto Nova Cartografia Social da Amazônia (PNCSA-UEA/UFAM). E-mail: aplluisster@gmail.com

\section{Márcia Helena Gomes}

Professora de Geografia da Rede Pública de Ensino do Estado de Rondônia (Seduc/RO). Chefe de Educação Escolar Indígena - CRE/ Seduc Cacoal. Mestre em Geografia pelo Programa de Pós-Graduação em Geografia da Universidade Federal de Rondônia (PPGG/UNIR). E-mail: marcia.gomes_ribeiro@hotmail.com

\section{Mirian Pereira Suave}

Professora de Geografia da Rede Pública de Ensino do Estado de Rondônia (Seduc/RO). Mestre em Geografia pelo Programa de PósGraduação em Geografia da Universidade Federal de Rondônia (PPGG/ UNIR). Membro do Grupo de Pesquisa em Gestão do Território e Geografia Agrária da Amazônia (GTGA/UNIR). E-mail: miriansinai@ hotmail.com 


\section{Súmula Curricular}

\section{Ricardo Gilson da Costa Silva}

Professor do Departamento de Geografia, Coordenador do Programa de Pós-Graduação em Geografia (PPGG) e docente do Programa de Pósgraduação Mestrado Profissional Interdisciplinar em Direitos Humanos e Desenvolvimento da Justiça (Dhjus) da Universidade Federal de Rondônia (UNIR). Doutor em Geografia Humana pela Universidade de São Paulo (USP), e Posdoctorado en Ciencias Humanas y Sociales en la Facultad de Filosofía y Letras de la Universidad de Buenos Aires (UBA). Coordenador do Laboratório de Gestão do Território (Laget) e do Grupo de Pesquisa em Gestão do Território e Geografia Agrária da Amazônia (GTGA/CNPq). E-mail: rgilson@unir.br

\section{Rosangela Castilho Valenciano}

Professora da rede pública municipal de ensino de Ji-Paraná, Rondônia. Graduada em Geografia, mestra pelo Programa de Pós-graduação em Geografia da Universidade Federal de Rondônia (PPGG/UNIR). Membro do Grupo de Pesquisa em Educação na Amazônia - GPEA/ UNIR. E-mail: rosangelacastilhovalenciano@gmail.com

\section{Tiago Roberto SiLva Santos}

Professor de Geografia no Instituto Federal de Rondônia - Campus Cacoal. Mestre em Geografia e Doutorando no Programa de PósGraduação em Geografia da Fundação Universidade Federal de Rondônia (PPGG/UNIR). Pesquisador do Grupo de Pesquisa em Gestão do Território e Geografia Agrária da Amazônia (GTGA/UNIR/CNPq). E-mail: tiago.santos@ifro.edu.br 
1ª edição: dez. 2021

Fonte utilizada: Sabon

Formato: $16 \times 23 \mathrm{~cm}$ (Livro digital) Porto Velho - RO 
